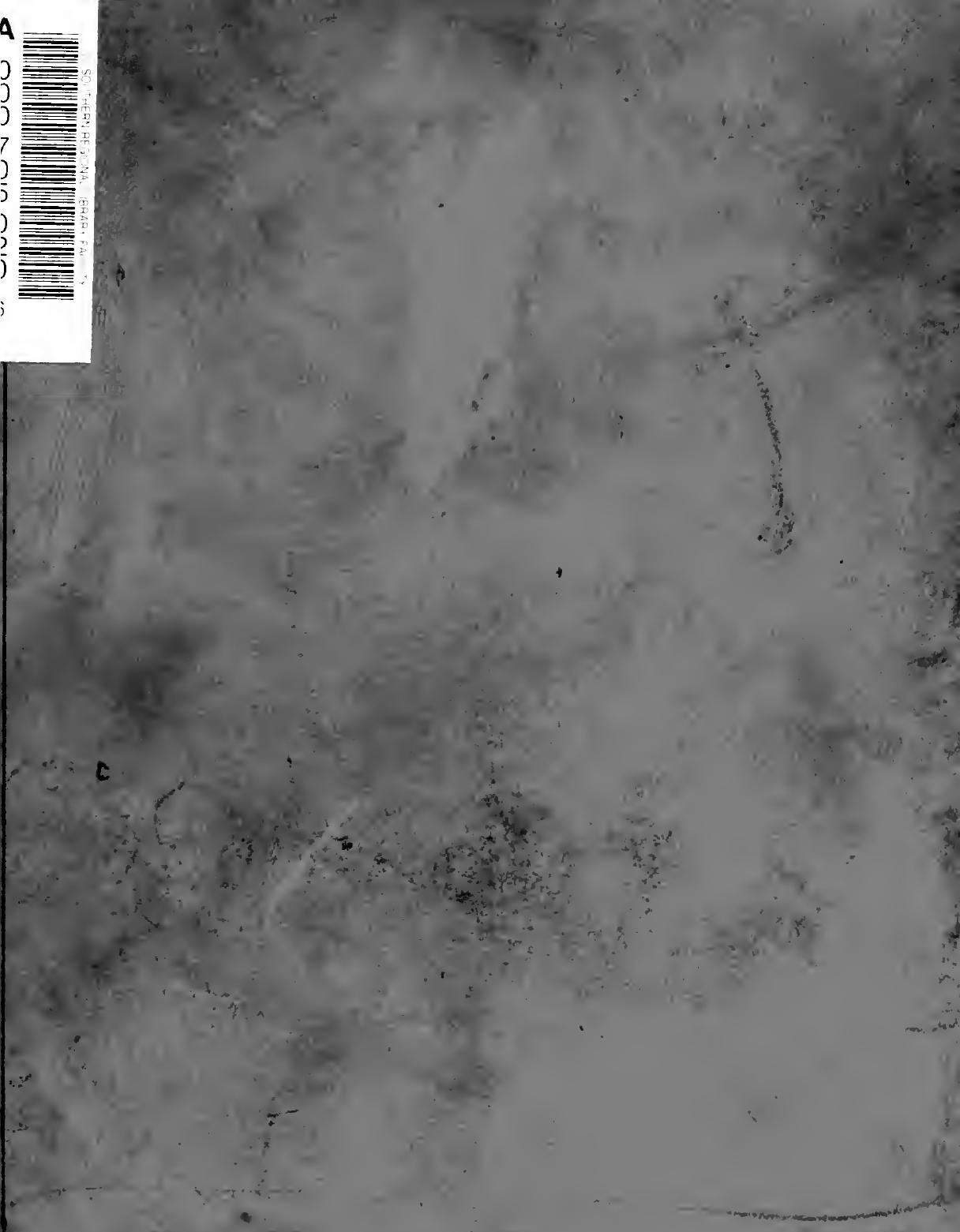




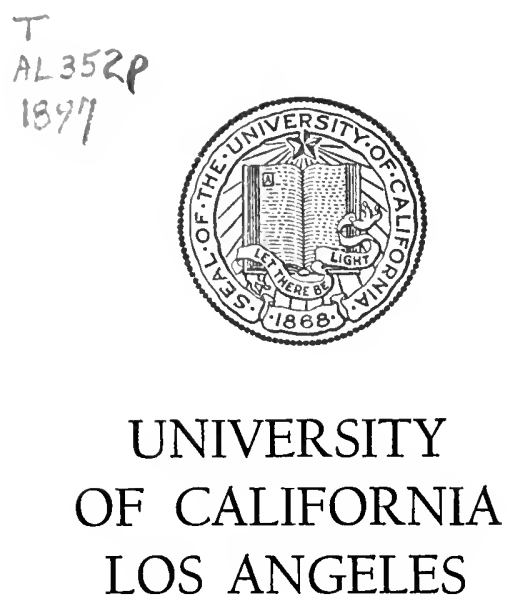

0.2

SCHOOL OF LAW

LIBRARY 
Digitized by the Internet Archive in 2007 with funding from Microsoft Corporation 


\section{A TREATISE ON THE LAW}

IN RELATION TO

\section{PROMOTERS AND THE PROMOTION \\ OF}

\section{CORPORATIONS.}



A

\title{
TREATISE ON THE LAW
}

IN RELATION TO

\section{PROMOTERS AND THE PRONOTION}

\author{
OF \\ CORPORATIONS.
}

BY

ARTHUR M. ALGER.

B O T T N :

LITTLE, BRoWN, AND COMPANY.

1897. 
Copyright, 1897,

By Arthur M. Alger.

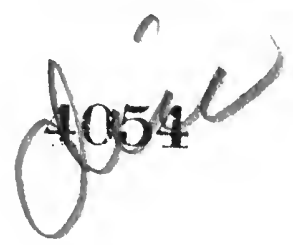

T

A $352 p$

$189 \pi$

Canibersity 扔ess:

John Wilson and Son, Cambridge, U.S.A. 


\section{P R E F A C E.}

THE public is eonstantly responding to the invitations of promoters of corporate enterprises to contribute the funds necessary for their prosecution. Very large sums of money in the aggregate are annually invested in such ventures by persons who must necessarily rely more or less upon the good faitl and integrity of those engaged in promoting them. The promoters "have in their hands the ereation and moulding of the corporation; they have the power to define how and when, and in what shape, and under what supervision, it shall start into existence and begin to act as a corporation." The material facts in relation to the undertaking are often exelusively within their knowledge. In view of these conditions, it is apparent that the question of the reciprocal rights and obligations of the promoter and the corporation, and of the shareholder and the promoter, is of great practical importanee; and it would seem to be worthy of fuller treatment than that which has been accorded to it in the text-books on the law of corporations. In the absence of any treatise on the subject, the writer

\section{0}


submits this work to the profession, in the hope that the attempt to do what so far has been left, to a great extent, undone, namely, to analyze the cases and to state and classify the principles deducible from the cases, may prove useful.

A. M. A.

MaY 1, 1897. 


\section{CONTENTS.}

\section{CHAPTER I.}

PAGE

Nature of Promotership and Relation of Promoters

to the Corporation .

$\S 1$. Explanation of term "promoter."

2. Term not applicable to one acting as an agent only.

3. In $r e$ The Great Wheal Polgooth Co., 53 L. J. Ch. 42.

4. One who is an agent may be a promoter also.

5. Agent may be promoter, although compensation does not come from corporation.

6. Central Land Co. v. Obenchain, 92 Va. 130.

7. Tests to ascertain who are promoters.

8. Ex-Mission Land \& Water Co. v. Flash, 97 Cal. 610.

9. St. Louis \& Fort Scott R. R. Co. v. Tiernan, 37 Kan. 606.

10. Question of fact whether one is a promoter.

11. Emma Silver Mining Co. $v$. Lewis, 4 C. P. D. 396.

12. Bagnall $v$. Carlton, 6 Ch. D. 371 .

13. Nant-y-Glo \& Blaina Iron Works Co. v. Grave, 12 Ch. D. 738.
$\S$ 14. Twycross $v$. Grant, 2 C. P. D. 469.

15. Lydney \& Wigpool Iron Ore Co. v. Bird, 33 Ch. D. 85.

16. Mere intent or agreement to promote does not make one a promoter.

17. Absolute purchase of property with view to resale to projected corporation as evidence of promotership.

18. Ladywell Mining Co. v. Brooks, 35 Ch. D. 400.

19. Conditional purchase of property with view to resale to projected corporation as evidence of promotership.

20. Promotership not limited to period anterior to organization of corporation.

21. Fiduciary relation of promoters to corporation.

22. Existence of such relation established by authorities.

23. Consequences of fiduciary relationship.

\section{CHAPTER II.}

Duties of Promoters to the Corporation . . . . . 25

$\S 24$. Duties of promoters in organization of corporation.

25. Erlanger $v$. New Sombrero Phosphate Co., 3 App. Cas. 1218.

26. Judgment of Lord Cairns.
$\S 27$. Exception to rule laid down by Lord Cairns.

28. Promoters must disclose their interest in transactions with corporation. 
§ 29. As rendo. of corporation not always bound to disclose cost of property to them.

30. Under some circumstances must disclose such cost.

31. Trustees not permitted to make secret profit in matter of trusteeship.

32. Similar rule applies to promoters.

33. Mere declaration that promoter is interested not enough when made to the directors only.

34. Imperial Mercantile Credit Association $v$. Coleman, $\mathbf{L}$. R. 6 H. L. 189.

35. Disclosure of interest only sufficient if made to the shareholders.
§36. Full disclosure must be made.

37. In re Westmoreland Green \& Blue Slate Co., 2 Ch. (1893) 612.

38. To whom disclosure must be made and by whom acted upon.

39. Effect of disclosure to, and consent by, all the shareholders representing entire capital stock.

40. Effect of disclosure to and consent by all the existing shareholders, when entire capital stock not issued.

41. Ultra vires acts not validated by disclosure to and consent by all the shareholders.

\section{CHAPTER III.}

Accountability of Promoters to the Corporation for Profits, Gifts, and Commissions . . . . . . 41

Article I. - Accountability of Promoters for Profits obtained by them as Vendors of the Corporation.

§42. Right of corporation to claim benefit of purchase made by promoters while such.

43. Tyrrell $v$. Bank of London, 10 H. L. C. 26.

44. Mere fact that property purchased by promoters while such does not entitle corporation to benefit of pur. cliase.

45. Benson v. Heathorn, 1 Y. \& C. 326 .

46. Right of corporation to claim benefit of purchase made by promoter before be became such.
\$ 47. In re Ambrose Lake Tin and Copper Mining Co., $14 \mathrm{Ch}$. D. 390 .

48. Ladywell Mining Co. v. Brooks, 35 Ch. D. 400.

49. Colorable transfer of property to promoter to be by him sold to the corporation.

50. Whaley Bridge Calico Printing Co. v. Green, 5 Q. B. D. 109.

51. Acts and declarations of promoter giving corporation right to claim benefit of purchase made by him. 
$\S 52$. Simons $v$. Vulcan Oil Co., 61 Penn. 202.

53. Burbank $v$. Dennis, 101 Cal.90.

54. Riglt of corporation to benefit of optional purchase made by promoter before becoming such.

55. Offer by promoter to corporation entitling it to benefit of his purchase.

56. Plaquemines Tropical Fruit Co. v. Buck, 52 N.J. Eq. 219.

57. Pittsburg Mining Co. v. Spooner, 74 Wisc. 307.

58. Right of corporation to benefit of optional purchase made by third persons confederating with promoter.
$\S 59$. Fountain Spring Park Co. $v$. Roberts, 92 Wisc. 345 .

60. Right of corporation to recover the profit made by promoter on a sale of his property to it. Definition of term "profit."

61. Recovery of profit when property sold is a commodity having a current market price.

62. Recovery of profit when property sold is not a commodity with current market price.

\section{Article II. - Accountability of Promoters for Gifts and}

Commissions. . . . . . . . . . . . . . . . 71

$\S 63$. Explanation of term "promotion money."

64. Accountability of promoters for promotion money.

65. Hichens $v$. Congreve, 4 Russ. 562 ; 1 Russ. \& Myl. 150, n.

66. Beck $v$. Kantorowicz, 3 Kay \& J. 230.

67. Lydney \& Wigpool Iron Ore Co. v. Bird, 33 Ch. D. 85.

68. Bagnall $v$. Carlton, $6 \mathrm{Ch}$. D. 371.

69. Emma Silver Mining Co. $v$. Grant, 11 Ch. D. 918.

70. Emma Silver Mining Co. $v$. Lewis, 4 C. P. D. 396.

71. MeElheney's Appeal, 61 Penn. 188.

72. Chandler $v$. Bacon, 30 Fed. Rep. 538.
§ 73. In re Westmoreland Green \& Blue Slate Co., 2 Ch. (1893) 612.

74. Yale Gas Stove Co. v. Foley, 64 Conn. 105.

75. Right of corporation to recover from vendor promotion money which he bas secretly agreed to pay to promoter.

76. Accountability to corporation of persons confederating with promoters.

77. Right of corporation to recover from promoters gifts and commissions not obtained at its expense.

78. In re North Australian Territory Co., 1 Ch. (1892) 322. 


\section{CHAPTER IV.}

Measure of Profits recoverable by Corporation. -

Statute of Limitations as a Bar to Suit for thieir Recovery. - Survival of Cause of Action . . . 89

$\S 79$. View that net profit only recoverable.

80. Moditication of this view. No allowance for expenditures ultra vires the corporation.

81. English decisions based on provisions of the Companies Acts.

82. Interest recoverable.

83. Rule when gift, commission, or profit is in form of shares of corporation's stock.

84. Statute of Limitations as a bar to suit to recover profits.
§ 85. Metropolitan Bank $v$. Heiron, 5 Ex. D. 319.

86. Statute runs from time of disclosure to or knowledge by corporation.

87. In re Fitzroy Bessemer Steel Co. $v$. Smith, 50 L. T. Rep. N. s. 144.

88. Right of action not divested short of period of statute without accord and satisfaction or release under seal.

89. Right of action survives against personal representatives of promoters.

\section{CHAPTER V.}

Breach of Duty or Fraud by Promoters as Grodnd for Recovery of Damages from them by CorporaTION, AND FOR PROCURING THE SETTING ASIDE OF EXECUted Contracts entered into by IT • . . . . 98

\section{Article I. - Liabilities of Promoters in Damages to the Corporation.}

$\S 90$. Rule laid down in Taylor on Corporations.

91. Damages recoverable for breach of duty damnifying corporation.
$\S 92$. Instances where promoters liable to corporation in damages. 
Article II. - Rescission by Corporation of Contracts entered into BY it with or through Promoters . . . . 102

§93. Rescission an elective remedy.

94. Rescission of contracts on ground of breach of duty by promoters.

95. Erlanger $v$. New Sombrero Phosplate Co., 3 App. Cas. 1218.

96. Atwool v. Merryweather, 5 Eq. 464, n.

97. Phosphate Sewage Co. v. Hartmont, 5 Ch. D. 394.

98. Caveat emptor not applicable to dealings by promoters with corporation.
$\S 99$. Rescission by corporation of transactions with third persons on ground of participation by such persons in frauds of promoters.

100. Election by corporation to confirm or rescind contract.

101. Right to rescind barred by laches.

102. Return of consideration received ordinarily condition precedent to right to rescind. Exceptions.

103. Partial rescission not allowed.

104. Burden of proof in suit for rescission.

\section{CHAPTER VI.}

Suits by Shareholderis to compel Redress for Wrongs by Pronoters to the Corporation . . . . . . 114

$\S 105$. As general rule suit can be brought only by corporation.

106. Exceptions to this rule.

107. Proof necessary to establish disability of corporation to sue.

108. Transactions on account of which shareholders may or may not bring suit.

109. Exposition of rule on this subject by Lords Justices James and Mellish.

110. Right of minority shareholders to sue to rescind transaction voidable for fraud, when majority are the wrong-doers.
$\S 111$. Atwool $v$. Merryweather, 5 Eq. 464, $n$.

112. Mason $v$. Harris, $11 \mathrm{Ch}$. D. 97.

113. Right of minority, where majority are not the wrong-doers, to sue to rescind contracts voidable for fraud.

114. Foss $v$. Harbottle, 2 Hare, 461.

115. Right of minority to sue to rescind a voidable transaction where there is no fraud.

116. Right of minority to sue for recovery of secret profits obtained by promoters. 
$\S 117$. Majority not allowed to retain profits wrongfully obtained at expense of minority.

118. Right of minority to sue for recovery of promoter's profits on sale to corporation at fraudulently excessive price.
§ 119. Shareholder whose shares have been voted on in favor of a transaction cannot maintain suit based upon it.

120. Rule in Federal Courts.

121. Shareholders' suit may be barred by laches.

122. Form of shareholders' suit.Necessary parties.

\section{CHAPTER VII.}

Liability of Pronoters to account for Profits, Commissions, and Gifts, or in Damages to Shareholders of the Corporation . . . . . . . . . . . 131

\section{Article I. - Liability to Accodnt for Profits, Gifts, and Commissions.}

$\S 123$. Effect of invitation by promoters to others to join them in acquiring property, and to become shareholders in corporation to be formed to purchase it.
$\S$ 124. Emery v. Parrott, 107 Mass. 96.

125. Getty $v$. Devlin, 54 N. Y. $403 ; 70$ N. Y. 504.

126. Rule as to joinder of plaintiffs in suit against promoters for an accounting.

\section{Article II. - Liability in Damages when in a Fiduciary}

Position toward Shareholders. . . . . . . . . . . 135

$\S 127$. When such relation exists between promoters and shareholders, former liable to latter in damages for breach of fiduciary duty to them.
$\S$ 128. Brewster $v$. Hatch, 122 N. Y. 349.

129. Teachout $v$. Van Hoesen, 76 Iowa, 113. 
Fiddciary Position toward Shareholders. . . . . . . 140

$\S 130$. Promoters ordinarily not in fiduciary position toward subscribers for shares.

131. When action will lie in favor of subscribers against promoters for misrepresentations.

132. Misrepresentation must be assertion of fact.

133. Mere commendatory expressions privileged.

134. Representation as to value in exceptional circumstances not privileged.

135. Representation as to price paid by third persons for shares or as to cost of company's property not privileged.

136. Commendatory expressions in prospectuses.

137. Expressions of opinion, although untrue, not actionable.

138. Representations as to the law.

139. Representation must be of a naterial fact.

140. Promoters as a rule not liable to purchasers of sliares for misrepresentation in prospectus addressed by them to prospective subscribers for shares.

141. But connection between promoters issuing prospectus and persons purchasing shares in reliance upon it may be shown.

142. Andrews $v$. Mockford, 1 Q.B. (1896), 372.

143. Representation must be fraudulent as well as false. Facts to be proved to establish fraud.

144. False representation made as of one's own knowledge deemed fraudulent.

145. Absence of reasonable grounds for belief in representation evidence that it is fraudulent.
$\S 146$. Effect of subsequent discovery by one who luas made representation that it is untrue.

147. Fraud may be inferred from concealment as distinguished from non-disclosure of material facts.

148. Circumstances under which non-disclosure of facts may make facts stated false.

149. Omission of facts from prospectus not ground for action of deceit, unless it makes facts stated false.

150. Peek $v$. Gurney, L. R., 6 H. L. 377.

151. Statement of portion of truth with suggestions and inferences rendered credible only by suppression of otler portions of truth.

152. Rules as to misrepresentation and non-disclosure not the same in actions ex-delicto as in suits for equitable relief.

153. No legislation in this country requiring promoters' agreements to be disclosed in prospectuses.

154. English statute on subject.

155. Right of subscriber to rely on representations addressed to him.

156. Liability of promoters on sale of shares issued to them at discount or in payment for property at overvaluation.

157. Liability of promoters for misrepresentations made by co-promoters.

158. Conflicting views as to measure of damages.

159. Rule in Massachusetts and other jurisdictions.

160. Rule in New Jersey.

161. Rule laid down in England and by Supreme Court of United States. 


\section{CHAPTER VIII.}

Liability of Pronoters to Subscribers for Shares in

a Projected Corporation which proves abortive 169

$\$ 162$. Promoters, in such case, may be liable to refund moneys paid in advance on shares by subscribers.

163. No deduction allowed for expenses, unless subscriber has authorized deposit to be applied thereto.

164. What subscriber must prove in order to recover from promoters.
§ 165. Burnside v. Dayrell, 3 Ex. 224.

166. Criticism of Burnside $v$. Dayrell.

167. Subscriber has no lien on moneys advanced as against creditors of company.

168. Subscriber's remedy is at law, unless fraud shown, or accounting necessary.

169. Apperly v. Page, 1 Phill. 779.

\section{CHAPTER IX.}

Remedies of Subscribers for Shares against CorpoRation WHEN MISLED BY MisRepresentations Made by Promoters or by their Non-disclosure of Material Facts . . . . . . . . . . . . 176

Article I. - Liability of Corporation in Damages for Fraddulent Misrepresentations made by Promoters.

$\S 170$. Action of deceit will lie against a corporation.

171. Corporation not liable in damages for frauds committed by promoters prior to its formation.
$\S 172$. Effect of insolvency of corporation on right of suit by subscriber against it to recover damages. 
Article II. - Misrepresentation or Non-disclosure of Material facts by Promoters as Ground for Rescission of Subscriptions for Shares, or as a Defence to Suits thereon by the Corporation . . . . . . . . . . . . . . . . 179

$\S 173$. Responsibility of corporation for misrepresentation or non-disclosure by promoters before corporation formed.

174. Subscribers' remedies against corporation for fraudulent misrepresenta. tion by promoters.

175. Remedy when misled by non-disclosure of facts by promoters.

176. Dicta of Vice Chancellor Kindersley.

177. Dicta of Lord Chelmsford.

178. Standard of duty as to disclosure required by dicta quoted. Whether legal or moral duty.

179. Peek v. Gurney, I. R. 6 H. L. 377.

180. Duty to disclose material facts not a legal duty, when omission does not make facts stated false.

181. Absence of direct decisions on this point. Reasons for and against requirement of disclosure.

182. Contracts to take shares governed by maxim caveat emptor.

183. Views of Brett, J., expressed in Gover's Case, 1 Cl. D. 182.
$\S 184$. Relief obtainable in Equity, and in some jurisdictions at law, against innocent misrepresen tation.

185. No relief at law where distinction in procedure between action at law and suit in Equity adhered to.

186. Principle on which Equity rescinds or refuses to enforce contract induced by innocent misrepresentation.

187. Proof necessary to obtain rescission of contract of subscription on ground of innocent misrepresentation.

188. Laches as a bar to rescission of contract of subscription.

189. Waiver of right to avoid sulscription on ground of misrepresentation.

190. Burden of proof on question of laches or waiver.

191. Rule in England as to effect of corporate insolvency on right to rescind contract of subscription.

192. Tendency of decisions in this country.

193. Repudiation of contract of subscription without suit for rescission effective, although corporate insolvency proceedings subsequently begun. 


\section{CHAPTER X.}

Rights and. Liabilities of Corporation on Promoters'

Article I. - Enforcement by or against the Corporation of

Contracts made in its Name and for its Benefit by its Promoters before it comes into Existence.

$\S 194$. Such contracts as a rule primarily not binding upon or enforceable by the corporation.

195. Penn Match Co. v. Hapgood, 141 Mass. 145.

196. Long $v$. Citizens' Bank, 8 Utah, 104.

197. Gooday v. Colchester, \&c. Ry. Co., 17 Beav. 132.

198. Buffington v. Barden, 80 Wisc. 635 .

199. By weight of authority, corporation cannot ratify contract made for it before its creation.

200. Doctrine held by Lord Cottenham.

201. Decisions of Lord Cottenham questioned.

202. Corporation may accept or adopt contracts made for it prior to its creation.

203. Effect of such adoption or acceptance.

204. Acceptance or adoption may be express.

205. Stanton $v$. New York \& Eastern R. R. Co., 59 Conn. 272.

206. Acceptance or adoption by corporation may be inferred from its acts.
$\S 207$. Taking benefit of contract may be evidence of acceptance or adoption.

208. Circumstances under which it establishes acceptance or adoption.

209. Battelle $v$. Northwestern Cement \& Concrete Pavement Co., 37 Minn. 89.

210. Pittsburg \& Tennessee Copper Co. v. Quintrell, 91 Tenn. 693.

211. Acceptance by corporation of subscriptions for shares made before its formation.

212. Cases in which term ratification used in sense of adoption or acceptance.

213. Paxton Cattle Co. $v$. First National Bank of Arrapahoe, 21 Neb. 621.

214. Distinction between ratification and adoption or acceptance.

215. English doctrine as to promoter's contracts.

216. Howard $v$. Patent Ivory Mfg. Co., 38 Ch. D. 156.

217. Corporation cannot adopt or accept ultra vires contracts. 
PAGE

Article II. - Lrability of Corporation to pay its Promoters ' or Persons employed by them, for Services and Expenses incident to tts Formation . . . . . . . . . . . . . . 220

$\S 218$. Statutory liability.

219. Liability under the English Companies Acts.

220. Melhado $v$. Porte Allegre; New Hamburgh, \& Brazilian Ry. Co., L. R. 9 C. P. 503.

221. Liability on quantum meruit.
$\S 222$. Doctrines held in this country as to liability of corporation.

223. Liability to pay for services and expenses in obtaining subscriptions for shares.

224. Doctrine lield in Vermont and New Hampshire.

\section{CHAPTER XI.}

Rights and Liabilities of Promoters under Contracts

MADE BY THEM, OR BY THEIR CO-PROMOTERS, IN BEHALF of or for the Benefit of a Projected Corporation. - Contracts between Pronoters . . . . 228

$\S 225$. Promoter not liable on contract made in name of intended corporation, unless he agreed to be so.

226. Presumption as to intent of parties.

227. Landman $v$. Entwistle, $7 \mathrm{Ex}$. 632.

228. On written contract question of intent is for the Court. - Kelner $v$. Baxter, L. R. 2 C. P. 174.

229. Scott v. Ebury, L. R. 2 C. P. 255.

230. Promoter usually not liable on contract made in name of corporation. - Liable for misrepresentation as to existence of corporation.

231. Effect of adoption by corporation of contract on which credit.was given to promoter.

232. Abbott $v$. Hapgood, 150 Mass. 248.

233. Promoters not prima facie partners.
$\S 224$. English cases as to liability of promoters on contracts made by co-promoters.

235. Ordinarily promoter nót liable from allowing his name to appear in prospectus or signing articles of incorporation, if he does not act in undertaking.

236. Statements in prospectus in which promoter allows his name to be used may impose liability upon him.

237. When promoter has acted in undertaking, question for jury whether he has authorized co-promoters to bind him.

298. Riley $v$. Packington, L. R. 2 C. P. 536.

239. Promoter's liability on contract made before he became a promoter. - Effect of admission of liability.

240. To hold promoter, credit must have been given to him. 
$\S 241$. Joint liability of promoters. - Effect of release of one.

242. Right of promoter to indemnity from co-promoters.

243. Right of promoter to contribution from co-promoters.

244. Batard $v$. Hawes, 2 El. \& B. 287.

245. In absence of agreement, promoter cannot enforce payment for services from co-promoters.
$\S 246$. No contract between promoters to go forward implied from their association together.

247. Legality of agreements between promoters as to formation of corporation and its future management and control.

248. Agreement between promoters restricting sale of their stock.

\section{CHAPTER XII.}

Rights and Liabilities under Contracts made by

Promoters claiming to be incorporated when the Proceedings, taken to ixcorporate have been

$\S 249$. Question as to consequences of illegal or defective incorporation by promoters.

250. Theory that corporation cannot come into existence without substantial compliance with enabling statute.

251. Conclusiveness of certificate of incorporation.

252. Nature and attributes of a de facto corporation.

253. Promoters and stockholders of a de facto corporation not liable for its debts.

254. What is necessary to constitute a de facto corporation.

255. A valid enabling statute.

256. Color of apparent organization under statute and user.

257. Effect of apparently real but in fact sham or fraudulent compliance with requirements of statute.

258. Construction of statute by courts of State where enacted followed by courts of other States.
\$259. Incorporation for apparently lawful, but in reality unlawful purpose, will not protect promoters.

260. Rule when corporation formed in good faith for lawful purpose.

261. Estoppel to deny corporate existence. Estoppel of the alleged corporation.

262. Estoppel of stockholders and promoters.

263. Estoppel of persons dealing with association as a corporation.

264. Estoppel to deny corporate existence of association in order to hold members individually liable on its contracts.

265. Rights and liabilities under contracts by or with association acting as a corporation, when there is no estoppel and no corporate existence even de facto. 


\title{
TABLE OF CASES.
}

\author{
[References are to Sections.]
}

Aaron's Reefs Co. $v$. Twiss 136,151

Abbott $v$. Hapgood $194,199,215,232$ v. Merriam

105

v. Omalıa Smelting Co. 250, 265

Adamantine Brick Co. $v$. Woodruff

Addlestone Linoleum Co., In re

Atna Ins. Co. $v$. Reed

Aldham $v$. Brown

Alexander $v$. Searcy

Allen $v$. Curtis $v$. Long

Ambrose Lake Tin \& Copper Mining Co., In re 28, 39, 46, 47, 156

American Loan \& Trust Co. $v$. Minnesota \& N. W. R. R. Co. 255

American Mortgage Co. of Scotland $v$. Ternille

American Salt Co. $v$. Heidenheimer

Anderson $v$. Hill

Andrew $v$. Tedford

Andrews $v$. Mockford

Angus $v$. Clifford

Apperly $v$. Page

Arkwright $v$. Newbold

Ashley's Case

Ashmead $v$. Colby

Ashpitel $v$. Sercombe $253,257,264$

Ashuelot Boot \& Shoe Co. $v$. Hoit 211

Ashurst's Appeal

Atchison, Topeka \& Santa Fe

R. R. Co. $v$. Davis

Athol Music Hall Co. v. Carey

Atlantic Bank $v$. Harris

$63,130,146$,

133

225

142

143

169

$148,149,180$

188

192

163

84

260

211

86

Attorney General $v$. Hanchett

Atwool v. Merry weather 96, 111, 112

Auburn Academy $v$. Strong

Avery $v$. Chapman v. Ryan

Babcock $v$. Case Bagnall v. Carlton
Bailey $v$. Birkenhead Ry. Co. $\quad 122$

$v$. Burgess 245

$v$. Macaully $235,238,239,240$

Baird $v$. Ross 163

Bank of Scotland $v$. Addie $\quad 170$

Bank of Shasta $v$. Boyd 263

Barker $v$. Stead 235

Barr v. New York, Lake Erie \& Western R. R. Co. 100,119

Barry v. Croskey 140

Bartholemew v. Bentley $\quad 140$ v. Bushnell 144

Bartlett $v$. Tucker $\quad 230$

Batard v. Hawes 244

Battelle $v$. Northwestern Cement \& Concrete Pavement Co. 194,

202, 209

Baxter $v$. Moses

Bay v. Cook 225

Bayless $v$. Orne $\quad 107$

Beal $v$. Bass $\quad 262$

Beale $v$. Monk 239

Beck $v$. Kantorowicz $\quad 66$

Bedford $v$. Bagshaw $\quad 137$

Beetenn $v$. Burkholder $\quad 102$

Belav v. Bryan 173

Bell's Appeal 211

Bell's Gap R. R. Co. v. Christie 222

Bellairs $v$. Tucker 155

Bennett $v$. Gibbons $\quad 155$

Benson $v$. Heathorn $\quad 31,45$

Bentinck v. Fenn 61, 62, 91 ,

104

Bergen $v$. Porpoise Fislıing Co. 194

Berry v. Whitney 138

Bethell $v$. Bethell 138

Bigelow $v$. Gregory $\quad 250,265$

Bird's Case ' 251

Bird $v$. Kleiner 144

144 Bivleh-y-plom Lead Mining Co. $v$.

246 Baynes 174

Bjorngaard v. Goodliue County

102 Blain v. Agar 168

$12,32,64,68,77$, Blanchard $v$. Kaull 265

79 Bloomer $v$. Gray 134 
[References are to Sections.]

Bluehill Academy $v$. Witham

Bodley $v$. McChord

Bonaparte $v$. Baltimore, Hampden \& Lake Roland R. R. Co.

Boomer v. American Spiral Co. 202,210

Bosher $v$. Riclımond \& Harrisonburg Land Co. 1,174

Bosley $v$. National Machine Co. 170

Boston $v$. Simmons

Boston Rubber Shoe Co. $v$. Boston Rubber Co.

Boughton $v$. Standish

Boulton $v$. Peplow

Bower $v$. Fenn

Boyce $v$. Trustees of Towsonton Station of M. E. Churcli

Boyd $v$. Sims

Bradenstein $v$. Hoke

Bralford $v$. Harris

Bradley $v$. Poole

Branıton Ry. Co., In re

Brewer $v$. Boston Theatre Co.

Brewster $v$. Hatch

Brickley $v$. Edwards

Briggs $v$. Withey

Briglit $v$. Hutton

British Seamless Paper Box Co., In re

Broughton $v$. Broughton

Brown v. Castles $v$. Duluth, \&c. R. R. Co.

Browne $v$. La Trinidad

Browning $v$. Great Central Mining Co.

Brownlow $v$. Cauthers

Bruner $v$. Brown

Bryant $v$. Ocean Ins. Co.

Buffalo \& Allegheny R.R. Co. v. Cary

Buffalo \& Jamestown R. R. Co. $v$. Gifford

Buffalo \& Pittsburgh R. R. Co. $v$. Hatch

Buffington $v$. Barden

Burbank $v$. Dennis

Burbridge $v$. Morris

Burgess $v$. Sherman

Burnes $v$. Pennell

Burus v. Lane

Burnside $v$. Dayrell

Burr v. McDonald

Buschman $v$. Codd

Bushnell $v$. Consolidated Ice Machine Co.

249,261

194,198

$29,46,53$

238

241

173

138

165,166

107

161

256

Butchers \& Drovers' Bank v. McDonald

Butt $v$. Monteaux

263
194 Cabot $v$. Chester

144

144

Caledonian, \&c. Ry. Co. $v$. Hellens-

burg

194,201

Calleuder $v$. Plainsville \& Hudson

R. R. Co.

Campau $v$. Van Dyke

261

Campbell $v$. Fleming

Cape Breton Co., In re

101

137 Capel $v$. Sims Ships Compositions Co.

Capper's Case

233

Carey $v$. Des Moines Coal \& Mining $\mathrm{Co}$.

194

Cargill $v$. Bower 157

Carling $v$. London \& Leeds Bank

172,191

Case Mfg. Co. $v$. Soxman 226, 231

Caseaux v. Mali 140

Casey v. Galli $251,262,263$

Cassidy $v$. Globe Rubber Co. 170

Castner $v$. Walrod

Caswell $v$. Hunton

101

Catlin $v$. Green

135,139

Cedar Rapids Ins. Co. $v$. Butler 188

Central Agricultural \& Mechanical Association $v$. Alabama Gold Life Ins. Co.

Central City Savings Bank v. Walker

252

Central 265

Central Ry. Co. of Venezuela $v$. Kisch $126,148,155,177,188$

Chandler $v$. Bacon 32, 72, 83

Chaplin v. Clark 162

Charles River Bridge Co. v. Warran Bridge

Cliatham Furnace Co. v. Moffatt

Chester $v$ Comistock

Chicora Co. $v$. Crews

Childs $v$. Hurd 250

Cluabb $v$. Upton 192

Clark $v$. Anierican Coal Co. $\quad 119$ $v$. Jones

264

Clarke $v$. Dickson 102, 135

Clegg v. Hamilton \& Wright Grange Co. 250,265

Clements $\because$. Bowes $\quad 169$

Clinch $v$. Financial Corporation 113

Close $v$. Glen wood Cemetery $\quad 263$

Clough $v$. London \& Nortluwestern Ry. Co.

Cochran $v$. Arnold 253, 257

Coil $v$. Pittsburgh Female College

Cole $v$. O'Brien

Coleman $v$. Coleman

225

168 Coles $v$. Kennedy

139,148 
[References are to Sections.]

Collen $v$. Wright

Collingwood $v$. Berkley

Collins $v$. 'Towusend

Colorado Land \& Water Co. v. Adains

Colt $v$. Clapp $v$. Woolaston

Colton $v$. Stamford

Columbia Electric Co. $v$. Dixon 252

Conmercial Bank of Keokuk $v$. Pfeiffer

Concha $v$. Murietta

Cook $v$. Tullis

Coolidge $v$. Goddard

Cooper $v$. Schlesinger

Cornell $v$. Hay

Cortes $v$. Thanliauser

Cowley v. Smith

Cox $v$. Montgomery

Coxe $v$. State

Craig $v$. Phillips

Craigie $v$. Hadley

Cross $v$. Sackett

$140,141,156$

Crnssman $v$. Penrose Ferry Bridge Co.

Crow v. Green

Crown $v$. Brown

Croyle $v$. Moses

Crump v. U. S. Mining Co

Cunninglıam $v$. Edgefield \& Kentucky R. R. Co. $v$. Pell

Cushing $v$. Wyman

Dale \& Plant Co., In re

Danforth $v$. Cushing

Davis $v$. Betz

$v$. Dexter Butter \& Cheese Co.

v. Gemmell

$v$. Hamlin

v. Montgomery Furnace \& Chemical $\mathrm{Co}$

$v$. Stuard

Dawe $v$. Morris

De Bussche $v$. Alt

De Ruvignes' Case

Demarest $v$. Flack

Deming $v$. Darling

Denny $v$. Gilman

Densmore Oil Co. $v$. Densmore

$27,29,38,39,46,62$

Denton $v$. Great Northern Ry. Co.

v. MacNeil

136,168

Deposit Life Ins. Co. v. Ayscough

Derry $v$. Peek

$130,143,181$

205

123

168

155

263

89

199

135

144

154

98

144

101

255

154

170
137

246

144

147

174

192

122

102

199

155

138

205

121

42

212

100

132

85,88

83

257

133

151

140

68

174

230 Dimmock $v$. Hallett 133

236 Dimpfel $v$. Olnio \& Mississippi Ry.

188 Co. 120, 121

Dole $v$. Wooldredge $123,126,233$,

Dooley $v$. Cheshire Glass Co. 261

Joran $v$. Eaton

Dorris $v$. French

Dorsey Match Co. v. McCaffrey

Drouet $\boldsymbol{v}$. Taylor

170,172

Duffield $v$. E. T. Barnum Wire \& Iron Works

188,192

Duggan $v$. Colorado Mortgage \& Investment Co. 252, 253, 256, 257

Duke $v$. Taylor 264, 265

Duncan $v$. Niles 230

Dunphy $v$. Traveller Newspaper

Association $107,108,121$

Duranty's Case 173

Duvergier $v$. Fellows $\quad 156$

Dynes $v$. Schaffer 188

EAGLesfield $v$. Londonderry 138

Eakright $v$. Logansport, \&c. R. R. Co.

249

Earl Lindsey $v$. Capper 201

v. Great Northern Ry. Co. 201

Earl of Shrewsbury $v$. North

Staffordshire Ry. Co. 194, 201

East Norway Lake Church $v$. Froislie

Eaton $v$. Walker $\quad 255,264,265$

Eden $v$. Ridsdale's Ry. Lamp \& Lighting Co.

Edgington $v$. Fitzmaurice 132,139

Edwards $v$. Grand Junction Ry. Co.

Eichbaum $v$. Irons 226

Eley v. Positive Assurance Co. 194 ,

Elizabethtown Gas Co. $v$. Green

Elizabethtown Gas

Ellis $v$. Andrews

133

Ely $v$. Hanford $\quad 46,62$

Emery $v$. Parrott $\quad 59,76,124$

Emly $v$. Lye. 207

Emma Silver Mining Co. $v$. Grant $32,69,79$

v. Lewis $\quad 1,10,11,32,70$

Empire Mills $v$. Allston Grocery Co. $263,264,265$

Empress Engineering Co., In re 194, $199,215,216,221,222$

Ennis Cotton Oil Co. v. Burks 225 ,

231

Erie City Iron Works v. Barber 144, 
[References are to Sections.]

Erlanger $\eta$. New Sombrero Phosphate Co. $1,5,17,21,25,27,28$, $38,42,46,62,95,100,101,154$

Eschweiler $v$. Stowell

Essex Bridge Co. v. Tuttle

Evensou $v$. Ellingson

Excelsior Pebble Phosphate Co. $v$. Brown

Exchange Bank of Kentucky $v$. Gaitskill

Ex-Mission Land \& Water Co. $v$. Flash $1,8,46,53$

Fairnanks' Executors v. Humphreys

Fairchild $v$. McMalıon

Farlow $v$. Ellis

Farmers' Co-operative Trust Co. $v$. Floyd

Farmers' Loan \& Trust Co. $v$. New York \& Northern Ry. Co. 110 Farmers' Stock Breeding Ass'n $v$. Scott

Farnham $v$. Benedict

Farrar $v$. Walker

Farwell $v$. Great Western Telegraph Co.

Faure Electric Accumulator Co., In re

Fawcett $v$. Charles $v$. Whitehouse

Fay $v$. Noble

Fear $v$. Bartlett

Felgate's Case

Ferris $v$. Thaw

Field $v$. Cooks

Finch $v$. Ullman

Finnegan $v$. Knights of Labor Buildling Ass'n

First Nat. Bank v. Almy

First Nat. Bank of Ft. Scott $v$. Drake

Fish $v$. Cleland

Fisher $v$. Worrall

Fitzroy Bessemer Steel Co., In re $38,83,87$

Flagler Engraving Co. v. Flagler 156

Flemming $v$. Weagley

Fogg $v$. Griffin

Ford $v$. McComb

Forrester $v$. Bell

Foss $v$. Harbottle

Foster $v$ Mansfield R. R. 105, 109, 114 $v$. Seymour

Fountain Spring Park Co. $v$. Roberts

Frankfort $v$. S. T. Co.

59,76

Franklin Fire Ins. Co, $v$. Hart

123
Fredenlaall $v$. Taylor

Fritts $v$. Palmer

Frost $v$. Belmont

222

Fuller $v$. Rowe

265

GALIGHeR $v$. Jones

Gamble $v$. Queen's County Water Co.

Garnett $v$. Richardson

Gartside Coal Co. v. Maxwell 253

Garwood $v$. Ede $\quad 163$

Gay v. Alter

102

Gent v. Manufacturers' Mutual Ins. Co. 194, 202

134 George Newman \& Co., In re 41

100 Gerhard $v$. Bates 141

Getty $v$. Devlin

Gilmore $v$. Bradford 230

Glassier $v$. Rolls

$46,125,128$

230
143

Gold Co., In re

39,156

Gooday $v$. Colchester, \&c. Ry. Co.

Goodin $v$. Cincinnati \& Whitewater

Canal Co.

Goodrich $v$. Reynolds $\quad 185$

Goodwin v. Home 132

$v$. Mass. Loan \& Trust Co. 184

Gordon $v$. Parmelee 133

Gover's Case $17,19,42,54,55,154$,

Gower $v$. Andrew $\quad 42$

Graham $v$. Nowlan 144

173 Grand Rapids Safety Deposit Co.

$v$. Cincinnati Safe \& Lock Co. 92

Grand River Bridge Co. $v$. Rollins

202, 210

Grand Trunk Ry. Co. v. Brodie 162,

Granger's Ins. Co. $v$. Turner $\quad 174$

Grant $v$. Law 103

Grape Sugar \& Vinegar Mfg. Co. v. Small

Grappengeisser $v$. Lake $\quad 184$

Gray $v$. Suspension Car Truck Mfg. Co.

v. Lewis

132

Great Luxembourg Co. $v$. Mag-

nay 62,100

144 Great Wheal Polgooth Co., In re 3

233 Green $v$. Barrett 168

Greene $v$. People 250

Greenhalgh $v$. Manchester, \&c. Ry. Co.

Greenly $v$. Hopkins

Gregory v. Patchett

Guckert $v$. Hacke

194, Gunn $v$. London \& Lancashire 
[References are to Sections.]

HAAS $v$. Bank of Commerce

Haase $v$. Mitchell

Haight $v$. Hay t

Hall $v$. Crandall

$v$. Johnson

$v$. Johnson
$v$. Vt. \& Mass. R. R. Co. 222, 224

Hambly $v$. 'Trott

Hamilton $v$. Clarion R. R. Co.

v. Granger's Ins. Co.

Hammett $v$. Emerson

Harrington $v$. Victoria Graving Dock Co.

Harris v. MeGregor

Haskell $v$. Worthington

Hissleman $\because$. U. S. Mortgage Co.

Hatchard $v$. Mège

Hatcher $v$. Hall

Hituse $v$. Hamenheimer

Haven $v$. Foster

Havens $v$. Hoyt

Hawes $v$. Oakland

Hawk $v$. Brownell

Hay's Case

Hayes $v$. Stanley

Hazard $v$. Durant

Heath $v$. Erie Ry. Co.

Hetden $v$. Griffin

Henninger $v$. Heald

Hereford Engineering Co., In re 199

Hereford South Wales Wagon Co., In re

Hersey $v$. Tully $v$. Veazie

Hess Mfg. Co., In re

Heymann $v$. European Central Ry. Co.

Hicliens $v$. Congreve

Higgins $v$. Crouse

$$
\begin{aligned}
& v \text {. Hopkins } \\
& v \text {. Lansingh } \\
& v \text {. Senior }
\end{aligned}
$$

Hill $v$. Beach

$$
\text { v. Hobart }
$$$$
v \text {. Nisbett }
$$

Hirslifield $v$. London, Brighton \& South Coast Ry. Co.

Holbrook $v$. Burt v. Connor

Holdom $v$. Ayer

Holmes $v$. Higgins

Home's Appeal

Hornblower $v$. Crandall

Houghton $v$. Butler

IIouldsworth $v$. City of Glasgow Bank

Houston $v$. R. R. Co.

Hovenden $v$. Lord Annesley

Howard $v$. Patent Ivory Mfg. Co.
256

155

230

89

252

74, 192 144

256

89

101

263

138

115

107

242

78

166

117

107

139

187

221,222

225

107

46

181,188

65

137

226

$39,46,62,103$

225,228

257

188

115

138

188

$133,134,137$

144

233

186

157,233

89

170,172

170

84 216
Howard $v$. Turner

192

Hubbard $v$. Weare

225

159

Hudson $v$. Green Hill Seminary 256

Hudson Real Estate Co. $v$. Tower 211

Hughes $v$. Antietam Mfg. Co. 137

Humphrey $v$. Merriam 144

Humphreys $v$. Mooney 265

Hungerford Nat. Bank $v$. Van Nostrand

264

Hunt $v$. Silk

Huntington \& Broad Top Ry. \& Coal Co. $v$. English

Huron Printing \& Binding Co. $v$. Kittleson

202,210

Hurst $v$. Salisbury $\quad 228,250$

Hutton $v$. Thompson 233

$v$. Uphill

233

Imperial Mercantile Credit Ass'n v. Coleman 30, 34, 35, 54

Indianapolis, Peru \& Chicago Ry. Co. $v$. Tyng

Insurance $\mathrm{Co}$. v. Harbor Protection Co.

Ives $v$. Carter

144

JACKsoN $v$. Stockbridge $\quad 144$

Jaggar $v$. Winslow 138

Jefts $v$. York 230

Jenkins $v$. Pye 101

Jennings $v$. Broughton 155

Jersey City Gas Co. v. Dwight 257

Jessop $v$. Ivory 189

Jessup $v$. Carnegie 258

Jewell $v$. Rock River Paper Co. . 192

Jewett $v$. Davis 187

Johnson $v$. Corsner 235, 265
162,166
$v$. Goslett
$v$. Smith
$225,228,230$

Johnston $v$. Gumbel 264

Jones $v$. Aspen Hardware Co. 263

$v$. Harrison 163

$v$. Johnson 105

$v$. Smith 101

Jordan $v$. Money 132

KaISER v. Lawrence Savings Bank

Kankakee \& Seneca R. R. Co. $v$. Horan

Karberg's Case 139, 171, 173, 174, 184

Keener $v$. Harrod 230

Kelner $v$. Baxter $194,199,215,220$, 
xxiv

Kennedy $v$. McKay $v$. Panama Mail Co. v. 'Thorp

Kenner $v$. Harding

Kilgore $v$. Bruce

Kilpatrick $v$. Reeves

Kimber $v$. Barber

King $v$. Barnes $v$. Eagle Mills

v. Sioux City Loan \& Inv. Co.

Kingston Cotton Mills Co., Re

Koop $v$. Bolımrich

Kost $v$. Bender

Kountze $v$. Kennedy

$143,144,184$

Ladywell Mining Co. $v$. Brooks $10,17,18,28,42,46,48,51,62,74$

Lagrone $v$. Timmerman

Lake ". Argyll

Lake Ontario Slore R. R. Co. $v$. Curtis

Lamning $v$. Galusha

Landis $v$. Sea Isle City Hotel Co.

Landman $v$. Entwistle

Lands Allotment Co. $v$. Broad

Larned $v$. Beal

Law $v$. Grant

Learing $v$. Wise

Lefray $v$. Gore

Lehman $v$. Warner

Le Lievre $v$. Gould

Lewis $v$. Tilton

Lindsay Petroleum Co. v. Hurd $99,101,135,190$

Long $v$. Citizens' Bank v. Woodman

194,196 132

Lord $v$. Copper Miners Co. 105, 109 $v$. Essex Building Ass'n

Lord Burns' Case

Lorillard $v$. Clyde

Loverin $v$. McLaughlin

Low v. Bouviere v. Conn. \& Passumpsic R.R. Co.

Lucas $v$. Beach

Lydney \& Wigpool Iron Ore Co.

$v$. Bird $1,2,4,15,21,32,67,80$

Lynde v. Anglo-Italian Hemp Spinning Co.

MacDovgalt, $v$. Garliner

Mackall $v$. Chesapeake Canal Co.

Mackay $v$. Bank of New Brunswick

Maddick ". Marslıall

247

185

134

91

107

134

107

224

233

109
171 Mahan $v$. Wood

211

185 Maitland's Case

166

100 Manahan $v$. Noyes 102

147 Mann $v$. Edinburgh Northern

135 Tramways Co. 41

144 Manning $v$. Albee 134

61 Manufacturers' Nat. Bank $v$. Perry

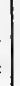

Marsh $v$. Falker

Marten $v$. Paul O. Burns Wine

Co.

Mason $v$. Harris

$v$. Waite

Matthews $v$. Bliss

Mayor, \&e. of Salford $v$. Lever

Me

76,9

134, 139 $v$. MeMurray 156

McArthur v. Times Printing Co.

McClellan $v$. Scott $199,202,203,210,214$

McClinch $v$. Sturgis

155

McCully v. Pittsburgh \& Connellsville R. R. Co.

McCurdy $\because$. Rogers

McEllieney's Appeal

225,230

189
230

McFadden $v$. Robinson 134

McGrew $v$. City Produce Excliange

McKay's Case

McKeon $v$. Boudard, Peveril Gear Co.

McKnight $v$. Pittsburgh 205

McTiglie $v$. Macon Construction Co.

255,256

Mead $v$. Bunn 155

Medbury $v$. Watson 134

Medenhall, In re 255

Medill $v$. Collier 257, 265

Meeker $v$. Winthrop Iron Co. 110

Melhado $v$. Port Allegre, New Hamburg \& Brazilian Ry. Co. 194, $199,215,219,220$

Menier $v$. Hooper's Telegraph Works 107, 117

Mercliants' Bank $v$. Stone 264

Merchants' \& Planters' Line $v$. Wagoner 107

Merriman $v$. Magiveny 256

Methodist, \&c. Church v. Pickett

Metropolitan Bank $v$. Heiron 84, 85

Metropolitan Coal Consumers Ass'n $v$. Scrimgeour

170 Meyer $v$. Staten Island Ry. Co. 
[References are to Sections.]

Michener $v$. Payson

Miller $v$. Barber

$v$. Murray

v. Wild Cat Gravel Road Có.

Ming $v$. Woolfolk

Mitchell v. Zimmerman

Mohler $v$. Carder

Mokelumne Hill Mining Co. $v$. Woodbury

249,250

Montgomery $v$. Forbes 250, 257, 264

Montreal River Lumber Co. $v$. Milhils

Moore $v$. Explosives Co.

v. Silver Valley Mining Co. 107

Moore \& Handley Hardware Co. $v$.

Tower's Hardware Co.

Morehouse $v$. Yeager

Moreland $v$. Atchison

Morgan $v$. McKee

$v$. Skiddy

$v$. Thetford

Moriarty $v$. Stafferan

Morse $v$. Hutchins $v$. Shaw

Morton $v$. Hamilton College

Moseley $v$. Cressey's Co.

Mozley $v$. Alston

Munson $v$. Syracuse, \&c. Ry. Co. 194

\section{NANT-Y-GLo \& Blaina Iron Works}

Co. v. Grave

$13,83,91$

Nash $v$. Minnesota Title Ins. \& Trust Co. $133,140,144,170$

National Debenture \& Assets Co., In re

Neall $v$. Hill

Neblett $v$. Macfarland

Nebraska Nat. Bank of York $v$. Ferguson

Newbiggin $v$. Adam

New Brunswick \& Canada Ry. Co. v. Muggeridge

New Sombrero Phosphate Co. $v$. Erlanger

Newton $v$. Belcher $v$. Blunt $v$. Iiddiard

21, 30, 54, 89 235,239

241

239

Newton Nat. Bank $v$. Newbiggen 193

New York Nat. Exchange Bank v. Crowell

264,265

New York \& New Haven R. R. Co. $v$. Ketchum

Nickels $v$. Crosby

Norbury's Case

Norris v. Cottle

North $v$. Phillips $v$. Stato

\section{PADDock v. Fletcher} $v$. Franklin Ins. Co.

129

Page $v$. McMillan

$$
v \text {. Parker }
$$

217

188

Panama \& South Pacific Tel. Co.

$v$. India Rubber, Gutta Percha \& Tel. Works Co.

Pape v. Capital Bank

Parker $v$. Moulton $v$. Nickerson

Parkin v. Fry

Parmelee $v$. Adolphe

Parsons $v$. Hayes $v$. McKinley

Pasley $v$. Freeman

Patrick $v$. Reynolds

Patterson $v$. Arnold $v$. Lippencott

Paxton v. Bacon Mill, \&c. Co.

Paxton Cattle Co. v. First Nat.

Bank of Arrapahoe

Payson $v$. Withers

Peabody $v$. Flint

Pearson's Case

133,134 42,61

245

185

39

188 .

155

235

257

230

194

Pease $v$. Gloaheck 101

Peebles $v$. Patasco Guano Co. $\quad 170$

Peek's Case

188

Peek $v$. Derry

161,184 $v$. Gurney $89,130,140,148,150$,

$\begin{array}{lr} & 179,187 \\ \text { Peel's Case } & 251\end{array}$

Peninsular R. R. Co. $v$. Duncan 211

Penn Match Co. v. Hapgood 194, $195,20 \% 2,214,215$

Penn. Mutual Iife Ins. Co. $v$. Crane

Penobscot R. R. Co. v. Dummer 211

People v. Central Pacific R. R. Co.

v. Clieeseman

$v$. Higgins

v. La Rne

v. Montecito Water Co, 250, 256

$v$. Stockton \& Visalia R. R. Co. 
[References are to Sections.]

Perley $v$. Balch

Perrine $v$. Grand Lodge

102, 188 Rickhoff $v$. Brown's Sewing Ma-

Perry $v$. Little Rock \& W. S. R.R Co.

Petre $v$. Eastern Counties Ry. Co.

Pettis $v$. Atkins

Philadelphia, Wilmington \& Baltimore R. R. Co. $v$. Cowell

Phillips $v$. Homfray

Plinizy $v$. A ugusta \& K. R. Co. 262

Phosphate Sewage Co. $v$. Hartmont

$64,77,97,102$

Pinto Silver Mining Co., In re 101

Pittsburg Mining Co. $v$. Spooner

Pittsburg \& Tenn. Copper Co. $v$. Quintrell

Planters' \& Miners' Bank $v$. Padgett

Plaquemines Tropical Fruit Co. $v$. Buck $19,22,26,54,56$

Pratt v. Oshkosh Match Co. 199,

Presby $v$. Parker

Preston $v$. Liverpool, \&c. Ry. Co.

Price $v$. Mulford

Priest $v$. White

Pulsford $v$. Richards

Queen City Furniture \& Carpet Co. v. Crawford

RAGAN $v$. McElroy

Railroad Gazette $v$. Wherry

Ramsey $v$. Thompson Mfg. Co.

Ramskill $v$. Edwards

Rand $v$. Webber

Randell $v$. Taimen

Rathbone v. Parkersburg Gas Co.

Rawson $v$. Harzan

Redding $v$. Godwin

Redgrave $v$. Hurd

Reeder $v$. Maranda

Reese River Silver Mining Co. $v$. Smith

Reichwald v. Commercial Hotel Co.

Rennie $v$. Clark

Reynell $v$. Lewis $v$. Sprye

Rice $v$. Nat. Bank of Commonwealth

Richlieu Hotel Co. $v$. International Military Encampment Co. 57,262

202,210 202,204

200,201

181 $199,202,231$

\section{chine Co.}

Riley $v$. Packington

252,263

Roberts, Ex parte 235

Roberts Mfg. Co. v. Schlick 238

Robertson $v$. Parks 144

Robinson $v$. Smith 105, 107

Rockford, Rock Island \& St. Louis

R. R. Co. $v$. Sage

Rogers $v$. Danby Universalist Society

$v$. New York \& 'Texas Land Co.

$202,210,212$

Roseman $v$. Canovan 147

Rotherham Alum \& Chemical Co., In re 218, 219, 221

Royal Bank of Liverpool $v$. Grand Junction R. R.

Russell $v$. Wakefield Waterworks Co.

Rutherford $v$. Hill

233,235

SALEM Mill Dam Co. v. Ropes 185

Salem Rubber Co. $v$. Adams 155

Salford, Mayor, \&c. of, $v$. Lever 76, 92

Salonion $v$. Salomon \& Co. $\quad 27,39$

Samuel $v$. Holladay 105

Sandy River R. R. Co. $v$. Stubbs 44

Sanford $v$. Handy 174

Sanger $v$. Upton 192, 211 $v$. Wood

Saunders $v$. Farmer

Savage $v$. Bartlett

Schiffer $v$. Dietz

Schloss $v$. Trade Co.

192,193

100

2 단, 263

Schreyer $v$. Turner Flouring Mills

Co.

202,210

Schwabocker $v$. Biddle $\quad 139$

$103 \begin{array}{cr}\text { Scott } v \text {. Dixon } & 141 \\ v \text {. Ebury } & 215,218,229\end{array}$

Scottish Northeastern Ry. Co. $v$.

Stewart 201

144 Scottish Petroleum Co., In re 188, 191

161 Seacord $v$. Pendleton 265

184,186

192

Searcy $v$. Yarnell

Seymour $v$. Spring Forest Cemetery Ass'n

Shanks $v$. Whitney

263

191

Shaw $v$. Davis

$\therefore 9$

205

226

Sheffield Nickel Co. $v$. Unwin 103

Sherman $v$. White 78,81

233, 235, 238 Shields $v$. Clifton Land \& Improve-

146

ment Co.

251

Shoe \& Leather Nat. Bank $v$. Dix

Short $v$. Stevenson

211 Simons $v$. Vulcan Oil Co. 38, 52, 53
Schranim $v$. O'Connor 
TABLE OF CASES.

[References are to Sections.]

Skegnors $v$. St. Leonards Tramway Co.

Smith $v$. Bolles

v. Brittenham

v. Chadwick

v. Duffy

$v$. Hurd

$v$. Newton

$v$. Sorby

$v$. Standard Laundry Machine Co.

$v$. Warden

Snider's Sons' Co. $v$. Troy 252, 253, 256,264

Snow $v$. Alley

$v$. Boston Blank Book Mfg. Co.

Snyder $v$. Studebaker

121

Society of Perun $v$. Cleveland 256

Society of Practical Knowledge $v$. Abbott

Sollund $v$. Johnson

Solomon $v$. Penoyer

Somers $v$. Richards

South Joplin Land Co. v. Case

Spahr $v$. Farmers' Bank $15,42,54$

Speidel $v$. Henrici

Spiller ". Paris Skating Rink

Spottiswoode's Case

Sproat $v$. Porter

Stafford Nat. Bank $v$. Palmer

Stanisby $v$. Fraser Metallic Life Boat Co.

Stanley $v$. Chester \& Birkenhead Ry. Co.

Stanton $v$. New York \& Eastern R. R. Co. 205,212

Starrett $v$. Rockland Ins. Co.

State $v$. Central Ohio Mut. Relief Ass'n

v. Critchett

$v$. Jefferson Turnpike Co.

$v$. Trustees Vincennes University

Stetson $v$. Patten

Stevenson $v$. Newnham

Stewart's Case

Stewart $v$. Stearns

$v$. St. Louis \& Fort Scott R. R. Co.

Stewart Paper Mfg. Co. v. Rau

Stiles $v$. White

$\begin{array}{ll}\text { Stiles } v \text {. White } & 157 \\ \text { St. John's Mfg. Co. v. Munger } & 173\end{array}$

St. Louis \& Fort Scott R. R. Co. $v$. Tiernan

Stofflett $v$. Strome

Stone $v$. Denny

Stout $v$. Zulick

Stowe v. Flagg

105

144

99

84

199

243

107

225

101

189

134
Stumpf $v$. Stumpf

138

133

154

161 Sullivan $v$. Mitcalfe

Supreme Court Independent Order Foresters of Canada $v$.

160 Supreme Court United Order Foresters

Swimm $v$. Bush

252,256

Swisshelm $v$. Swissvale Laundry Co.

202,210

Syracuse, Chenango \& New York R. R. Co., In re

119

Taite's Case

Tamplin's Case

188

Tarbell $v$. Page

187

Tarkinson $v$. Purvis

252

Taylor $v$. Leith

Teachout $v$. Van Hoesen

100

144

Teague $v$. Irwin

129

139

Ten Eyck $v$. Pontiac, Oxford \& Port Austin R. R. Co.

261

Tennent $v$. City of Glasgow Bank 191

Terwilliger $v$. Murphy 225

Thompson $v$. First Nat. Bank of Toledo

$v$. People

240

v. Phœenix Ins. Co.

249

138

Tift $v$. Quaker City Nat. Bank 222

Tilson $v$. Warwick Gaslight Co. 194

Totten $v$. Burlians 144

Tuckaseegee Mining Co. v. Goodhue

Turner $v$. Davies $v$. Grangers' Life \& Health Ins. Co.

263

241

Tuscaloosa Mfo $\quad 192$

Twin Lick Oil Co. $v$. Marbury 101

Twycross $v$. Grant $1,14,20,89,150$,

Tyler $v$. Savage $153,154,160,161,181$

Tyrrell $v$. Bank of London $\quad 3,43$

Union Nat. Bank $v$. Hunt

133

Union Pacific Ry. Co. $v$. Barnes 144

Unity Ins. Co. v. Cram 250

Upton v. Englehart $138,192,193$ $v$. Tribilock

$138,188,192$

VANE $v$. Cobbold

163

Van Epps $v$. Harrison

134

Vanneman $v$. Young 253, 256

263 Vawter $v$. Ohio, \&c. R. R. Co. 133

144 Veazey $v$. Doten 133

253, 256, 264 Vigers v. Pike 100

223 Vredenburg $v$. Behan 255 
[References are to Sections.]

Walker $v$. Mobile \& Ohio R. R. Co.

Wallace $v$. Lincoln Savings Bank 107

Walsham $v$. Stainton

Walstab $v$. Spottiswoode

Walton $v$. Oliver

Ward $v$. Brigham v. Lord Lodensborough

Warner $v$. Benjamin v. Seymour

89,157

162,166

250

$233,235,265$

162

139,159

155

Warren $v$. Para Rubber Shoe Co. 89

Watson $v$. Earl of Charlemont

Watt's Appeal

Weare $v$. Gove

Weatherford Mineral Wells \& Northwestern Ry. Co. v. Granger $199,202,224$

Webster $v$. Upton

Wechselberg $v$. Flour City Nat. Bank

Weir $v$. Barnett

Weiseger $v$. Richmond Ice Co.

West London Commercial Bank $v$. Kitson

West Point Foundry Ass'n $v$. Brown

Western Screw \& Mfg. Co. v. Cowsley 194,223

Westmoreland Green \& Blue Slate Co., In re

Whaley Bridge Calico Printing Co. $v$. Green $1,32,50,75,92$

Wheeler $v$. Pullman Iron \& Steel Co.

Wlite $v$. Madison 107

Whitney $v$. Robinson v. Wyman $212,225,252,253$
Wickersham $v$. Lee 86

Wilcox $v$. Iowa Wesleyan University

Wilkinson's Case

Willey $v$. Parrott

Williams $v$. McFaddon

$v$. Montgomery

$v$. Page

$v$. Salmond

Williamson $v$. New Jersey Southern R. R. Co.

Willonghby $v$. Chicago Junction Railway

Wilson $v$. Curzon

Windram $v$. French $138,155,156$

Wingett $v$. Quincy Building Ass'n 263

Winsor $v$. Bailey 122

Winters $v$. Hub Mining Co. 215

Wise $v$. Fuller 133

W. Laxon Co. No. 2

Wontner $v$. Sharp 189

Wood $v$. Argyll 233, 234 v. Cory Waterworks Co. 119

Woodbury Heights Land Co. $v$. Lodenslager $15,54,55$

Worth, Ex parte 173

Wright $v$. Bank of the Metropolis 83

Wylde $v$. Hopkins 233, 235

Yale Gas Stove Co $v$. Wilcox 22,

32, 74, 75

225 Yeates $v$. Hines 184

263 v. Prior 136

Young $v$. Alhambra Mining Co. 107 


\title{
THE LAW OF PROMOTERS
}

\author{
AND THE
}

\section{PROMOTION OF CORPORATIONS.}

\section{CHAPTER I.}

\section{NATURE OF PROMOTERSHIP AND RELATION OF PROMOTERS TO THE CORPORATION.}

$\S 1$. Explanation of term "promoter."

2. Term not applicable to one acting as an agent only.

3. In re The Great Wheal Polgooth Co., 53 L. J. Ch. 42.

4. One who is an agent may be a promoter also.

5. Agent may be promoter, although compensation does not come from corporation.

6. Central Land Co. v. Obenchain, 92 Va. 130.

7. Tests to ascertain who are promoters.

8. Ex-Mission Land \& Water Co. v. Flash, 97 Cal. 610.

9. St. Louis \& Fort Scott R.R.Co. v. Tiernan, 37 Kan. 606.

10. Question of fact whether one is a promoter.

11. Emma Silver Mining Co. $v$. Lewis, 4 C. P. D. 396.

12. Bagnall $v$. Carlton, 6 Ch. D. 371 .

13. Nant-y-Glo \& Blaina Co. v. Grave, 12 Ch. D. 738.
$\S 14$. Twycross $v$. Grant, 2 C. P. D. 469.

15. Lydney \& Wigpool Iron Ore Co. v. Bird, 33 Ch. D. 85.

16. Mere intent or agreement to promote does not make one a promoter.

17. Absolute purchase of property with view to resale to projected corporation as evidence of promotership.

18. Ladywell Mining Co. v. Brooks, 35 Ch. D. 400.

19. Conditional purchase of property with view to resale to projected corporation as evidence of promotership.

20. Promotership not limited to period anterior to organization of corporation.

21. Fiduciary relation of promoters to corporation.

22. Existence of such relation established by authorities.

23. Consequences of fiduciary relationship.

$\S 1$. Explanation of term "promoter." - The law imposes serious responsibilities upon persons who become promoters 
of corporations, holding them to a high standard of conduct, and subjecting to careful scrutiny their dealings with the corporation which they promote. It is accordingly important to inquire what constitutes one a promoter of a corporation. The first requirement would seem to be a definition. But it has become apparent that it is not practicable precisely to define the term "promoter" as used in connection with corporations. It is ambiguous, and it is necessary to ascertain in each case what the so-called promoter did, before his legal liabilities can be accurately ascertained. ${ }^{1}$ Therefore, what is really to be looked to is not a word or a name, but the acts and relations of the partics. $^{2}$ The term, however, is one of accepted use ${ }^{3}$ commonly employed to designate persons who take some part in procuring the formation of a corporation, or in inducing others to join it, and who in so doing assume such a position that a relation of a fiduciary nature between themselves and the corporation is created. ${ }^{4}$

1 Lindley, L. J., in Lydney \& Wigpool Iron Ore Co. v. Bird, $33 \mathrm{Ch}$. D. 85 .

${ }^{2}$ Bowen, L. J., in Whaley Bridge Calico Printing Co. v. Green, 5 Q. B. D. 109.

8 "It is a term not of law, but of business." Bowen, L. J., in Whaley Bridge Calico Printing Co. v. Green, 5 Q. B. D. 109.

4 The following explanations of the term may be found in the cases:-

"The term 'promoter' involves the idea of exertion for the purpose of getting up and starting a company (or what is called 'floating' it), and also the idea of some duty towards the company imposed by or arising from the position which the so-called promoter assumes toward it." - Lindley, J., in Emma Silver Mining Co. v. Lewis, 4 C. P. D. at p. 407.

"A promoter, I apprehend, is one who undertakes to form a company with reference to a given project, and to set it going, and who takes the necessary steps to accomplish the purpose."-Cockburn, Ch. J., in Twycross v. Grant, 2 C. P. D. at p. 541.

"A short and convenient way of designating those who set in motion the machinery by which the Act enables them to create an 
§ 2. Term not applicable to one acting as agent only. The term is not applicable to persons who do not put themselves in a fiduciary position toward the corporation, but act merely as agents of those who are forming or floating it. Thus, printers, advertising agents, and lawyers, employed by the projectors of a company to render the usual trade or professional services incident to its incorporation, or necessary to set it going, are not promoters. In one sense their acts tend to promote the company, but not in such a sense as to establish any relation between it and them. ${ }^{1}$

§ 3. Inustrative case. - In the case of In re Great Wheal Polgooth Co., ${ }^{2}$ one of the promoters of a company sold to it, for $£ 300,000$, property which he lad but a short time prior thereto purchased for $£ 10,000$. The solicitor acted as such in the incorporation of the company, and in the transfer of the property to it. Prospectuses of the company were handed to and distributed by him; and on a certain occasion when attacks upon the company had incorporated company." - Lord Blackburn, in Erlunger v. New SomUrero Phosphate Co., 3 App. Cas. at p. 1268.

" The term 'promoter' is a term not of law, but of business, usefully summing up, in a single word, a number of business operations familiar to the commercial world, by which a company is generally. brought into existence." - Bowen, L. J., in Whaley Bridge Calico Printing Co. v. Green, 5 Q. B. D. 109.

In Bosher v. Richmond \& Harrisonburg Land Co., 89 Va. 455, and ExMission Land and Water Co. v. Flash, 97 Cal. 610, the following definition from Cook on Stockholders, sect. 651, was adopted: "A promoter is a person who brings about the incorporation and organization of a corporation. He brings together the persons who become interested in the enterprise, aids in procuring subscriptions, and sets in motion the machinery which leads to the formation of the corporation itself."

1 "No doubt a very little will make people promoters of a company, if it can be seen that they were really doing something for their own interests, and not acting merely as agents for others." - Pearson, J., in Lydney \& Wigpool Iron Ore Co. v. Bird, 31 Ch. D. at p. 339.

253 L. J. Ch. 42. 
been made in a newspaper, he prepared an answer which he caused to be inserted in several newspapers. He had no interest in the company except the right to be paid for his labor. It was held that he was not a promoter. "The duty which the solicitor bears to the company has," said the vice-chancellor, "nothing to do with promotion." As to the sale of property to the company, the vicechancellor observed: "But what had the solicitor to do with that? He did not manage the company. He was not to advise them that it was not worth the money they were going to pay for it." And as to the matter of the prospectus, he observed: "Persons applying for prospectuses would apply where they could get them, and if they applied to him it was his business as the solicitor of the company, not as a promoter, that he should have the prospectuses to give them." 1

$\S 4$. One who is an agent may be a promoter also. - But persons who act as agents for the projectors of a corporation may nevertheless become promoters, if they engage in work of promotion. This is well brought out in the case of Lydney \& Wigpool Iron Ore Co. v. Bird. At the trial ${ }^{2}$ it appeared that the owners of some mines employed James Bird to form and launch a company for the purpose of purchasing the mines. Bird undertook all the business connected with the issuing of the prospectuses and the bringing out of the company. It was agreed between him and the owners, by an agrcement not disclosed, that he should be paid a commission of $£ 10,800$ out of the purchase money of $£ 100,000$, which was to be given by the company for the mines; and this payment was made after the formation of the company. An action

1 For circumstances under which a solicitor became a promoter, see Tyrrell v. Bank of London, 10 H. L. C. 26.

231 Ch. D. 328. 
was subsequently brought by the company against Bird to recover the commission retained by him. He alleged that all which he did, he did simply as an agent for the vendors; that the commission which he received was in payment for services rendered by lim as agent to the vendors. On the other hand, it was contended that he was himself interested in the company, besides being the agent of the vendors; that the company was as much his company as the company of the vendors; and that he was a promoter. The decision of the Court was made to turn on the question whether the purchase price to be given by the proposed company for the mines was purposely raised or "loaded," so that Bird's commission of $£ 10,800$ was paid out of the money of the company, and not out of money which under any circumstances would have gone to the vendors, or whether the purchase price of $£ 100,000$ was in good faith agreed to be paid without any regard to the sum which was to be paid Bird. On the evidence, the Court found that Bird's commission was to be paid by the rendors out of the purchase money which they were to receive from the company; that the company was not to pay any portion of it; and that accordingly Bird was acting merely as an agent, and not as a promoter. But the Court of Appeal ${ }^{1}$ took a different view of the evidence, holding that although an agent of the vendors to get up the company, he was acting not in their interest but in his own by causing the purchase price of the mines to be swollen, so that he might covertly take his commission from the coffers of the company; and that, although in getting up the company he was acting for the vendors, that did not absolve him from obligation to the company attached to the position which he assumed toward it. He was the agent

133 Ch. D. 85. 
of the vendors, but he was also the promoter of the company.

$\$ 5$. Agent may be promoter, although compensation does not come from corporation. - The fact that the commission or compensation of an agent employed to form a corporation does not come, directly or indirectly, from the corporation, is not conclusive that he is an agent only. Notwithstanding this fact, he may be a promoter also; as, for example, if he brings the corporation into existence and controls its organization, in order that it may purchase property or make some contract in which his principal has an interest. He then enters into a fiduciary relation with the corporation, and is responsible to it for wrong-doing in that relation, although committed by him for other people. ${ }^{1}$ The distinction is apparent between such a case as this and the case of the broker, the printer, or the lawyer, who act strictly as such, and are mere agents, no relation being established between them and the corporation.

$\S 6$. Illustrative case. - In Central Land Co.v. Obenchain, ${ }^{2}$ Obenchain and Joliffe brought an action against the corporation to recover $\$ 500$. Their claim was, that as agents of one Felix they had sold to the corporation a tract of land for the sum of $\$ 10,000$; that Felix had agreed to pay them a commission of five per cent for their services in effecting this sale; that the corporation paid Felix $\$ 10,000$, the purchase price of the land, but afterwards collected from him the commission of $\$ 500$, which was due them. It was contended by the corporation that when Obenchain and Joliffe became the agents of Felix, they were engaged in promoting the organization of the corporation, and in securing control of the land of Felix and of other lands to

1 Erlanger v. New Sombrero Phosphate Co., 3 App. Cas. 1218.

292 Va. 130. 
be purchased by the corporation when organized; that for these services they had been paid by the corporation under an agreement, referred to in the prospectus, providing for payment by the corporation to the promoters for their services; and that the corporation was entitled to collect and retain the commission in question, as a commission which Felix had without its knowledge agreed to pay to Obenchain and Joliffe for services in a transaction in which they were acting not alone as his agent, but also as promoters of the corporation. At the trial, the corporation requested the Court to instruct the jury that if they believed that Obenchain and Joliffe were instrumental in the organization or creation of the corporation, and secured the option from Felix for the purpose of aiding in the organization of a company for the purchase of the land from Felix, and that the corporation was subsequently organized by their efforts, with the assistance of others, then Obenchain and Joliffe were promoters of the corporation, and were not entitled to make a profit on the sale of the Felix land to the corporation, without its knowledge and consent. The Court refused to give this instruction. On appeal, it was held that the refusal to give the instruction as requested was error.

$\$ 7$. Tests to ascertain who are promoters. - It has been said that in seeking to ascertain who are the promoters of a company it is useful to ask, "Who started the idea of forming a company for the purpose in question ?" "Who settled what was to be included in the preliminary papers, or gave the lawyers instructions to prepare them, and information upon which they might be prepared?" "Who undertook the liability for the expense incident to the preliminaries of incorporation?" And, lastly, the question, "Cui bono?" — Who benefited by the formation of the company?" But none of these questions is decisire, for a 
man may have done one or more of these things as a mere agent, and not as a promoter at all; and on the other hand, a man may have kept in the background and have appeared to do none of these things, and yet be a promoter. Frequently the vendors of a company are the promoters of the company; but the owners of property may have been asked, "If a company is formed to acquire your property, will you sell it? and if so, at what price?" If they have done no more than agree to sell, they will not be promoters. It is to be noted, however, that the Court will look at the substance of the transaction, and vendors or others who are in reality the promoters will not escape liability by the interposition of a nominal vendor or a nominal promoter.who professes to purchase and re-sell, or to undertake the financial operations incident to forming and floating a company. ${ }^{1}$

$\S$ 8. Illustrative case. - In Ex-Mission Land \& Water Co. v. Flash, ${ }^{2}$ the facts were substantially as follows: At a judicial public sale of 4,500 acres of land belonging to the estate of one Olivera, the defendants became the purchasers at the price of $\$ 22,725$, or $\$ 5.05$ per acre. They paid down ten per cent, the required cash payment; the balance was to be paid in a fixed time, the deed to be delivered when this deferred payment was made. They then employed Wilson and Coleman as their agents to effect a sale of the lands at $\$ 25$ per acre, or $\$ 112,500$. In case of such sale, the defendants were to pay the agents a commission of $\$ 5.00$ per acre, or $\$ 22,500$, payable partly in notes of a corporation to be formed to purchase the lands. The agents induced subscriptions for stock in the intended corporation,

1 Jordan \& Browne on Joint Stock Companies, 62. The writer has stated the matter in the above paragraph, substantially in the language employed in the work cited.

297 Cal. 610. 
by representations that the defendants held a contract for the purchase of the lands in question from the estate of Olivera, at the price of $\$ 25$ per acre, which was the lowest price at which the land could be purchased, and that the subscribers for shares would "get in on the ground floor at bed-rock prices." The facts that the defendants had already bought the lands for $\$ 5.05$ per acre, that Wilson and Coleman were their agents, and were to receive from them a commission of $\$ 22,500$, if the sale to the corporation was brought about, were not disclosed. The corporation was formed under the promotion of the agents. The sum of $\$ 37,500$, which was paid in on subscriptions for stock, before and after the incorporation, was turned over to the defendants. From this sum the payment due under the judicial sale of the lands was made to the Olivera estate, and a deed was obtained, the title being taken in the name of one of the defendants. A conveyance was then made to a trustee for the corporation, which executed its notes for $\$ 75,000$, secured by a mortgage of the lands. In this way the defendants received the purchase price agreed upon, $\$ 112,500$. In a suit subsequently brought to obtain relief for the corporation from the fraud practised upon it, it became material to determine whether the defendants were promoters of the corporation. They contended, that while Wilson and Coleman, who had promoted the corporation, were their agents to bring about a sale of the lands, they were not their agents to promote the corporation, and had no authority from them to promote it; and it was not shown, they contended, that they themselves had done anything in the way of promotion. But the Court held, on all the facts, that they had employed the agents to act as promoters, and that in effect they had promoted the corporation through their agents. If Wilson and Coleman had, of their own motion and on their own account, determined to 
form a corporation, and had gone to the defendants and obtained an agreement from them to sell to the corporation, when formed, for $\$ 25$ per acre, and to pay a commission of $\$ 5.00$ an acre on the sale, the defendants, if they liad stopped therc, would not have been promoters. But the defendants themselves formulated a scheme to bring a corporation into existence to buy their lands, and they employed agents to form the corporation, to procure subscriptions for its stock, and to bring about the purchase of the lands by it. They were the real promoters of the corporation, although keeping under cover as promoters, and appearing openly only as rendors.

§ 9. In St. Louis \& Fort Scott R. R. Co. v. Tiernan, ${ }^{1}-$ Tiernan and Ayers, as two of the incorporators of the plaintiff corporation, signed and acknowledged the charter, January 20, 1880. They purchased a certain road-bed, February 17, 1880. The charter was filed and the corporation came into existence February 23, 1880, Tiernan and Ayers being among the first directors. In May, 1880, Tiernan and Ayers sold the road-bed to the corporation at a very great advance over its cost to them. It was plain from the facts found, that they bought the road-bed with intent to sell it to the corporation, when formed. On the ground that their position and interest were fully disclosed to all the shareholders in the corporation at the time of the transaction, the Court properly held that subsequent shareholders, at a later period, could not compel Tiernan to account to the corporation for his profit. But the Court also held that Tiernan was not a promoter, inasmuch as it did not appear that he had "advised or suggested the organization of the corporation." Obviously, this is not the exclusive test, as the Court apparently took it to be; and it seems clear that in holding that Tiernan was not a

137 Kan. 606. 
promoter, the Court was in error. "The word 'promoter," said Simpson, J., "had its origin in the methods by which joint stock companies were formed in England, where by law they were declared partnerships." Describing then the methods by which railroad corporations were formed in England by special act of Parliament, he observed: "This has 110 rescmblance to our method of organizing corporations. It is true that the word has been found to have its uses in our jurisprudence, but in a muclı more restricted sense than that used in the English reports." The learned judge apparently overlooked the fact that most of the corporations in England are formed under a general law, as they are in this country, and that it is only the unlimited liability corporations that are regarded as partnerships. With the exception of certain statutory liabilities which exist in England, the position of a promoter is substantially the same in our law as in the law of England, and the word "promoter" is not used in any different sense here than there.

$\S 10$. Promotership a question of fact. - It is a question of fact whether a person is or is not a promoter, and it may be left to the jury to determine. ${ }^{1}$ The following cases are selected to illustrate more fully the nature of promotership.

§11. Emma Silver Mining Co. v. Lewis. - A firm of metal brokers who were selling ore of the Emma Silver Mine in America, on a commission of two and one-half per cent., arranged with Park, one of the owners of the mine, to assist in its sale to a company to be formed by him in England to purchase it. He was to secure their employment as metal brokers of the projected company at the usual rate of English commission, one per cent., and he prom-

1 Emma Silver Mining Co. v. Lewis, 4 C. P. D. 396; Ladywell Mining Co. v. Brooks, 35 Ch. D. 400. 
ised to pay them $£ 5,000$ for their assistance, and to compensate them for the reduction in their commission. They were, as he knew, acquainted with facts detrimental to the reputation of the mine, and his real motive in promising payment of the large sum stated was to insure their silence respecting such facts. He procured the formation of a company, and the purchase by it of the mine at a price paid partly in eash and partly in paid-up shares. They assisted him in the sale of the mine, and permitted themselves to be named in the company's prospectus as ready to answer any inquiries in relation to the mine, and answered such inquiries, but were silent in respect to the detrimental facts known to them. They were appointed metal brokers of the company at the one per cent. commission, and were secretly paid the sum promised them by a transfer of two hundred and fifty paid-up shares out of those received from the company in payment of the purchase price of the mine. It was held that they were promoters. As the Court observed, "They left Park to get up the company, upon the understanding that they as well as he were to profit by the operation; they were behind him; they were in the position of undisclosed joint adventurers. But they not only left Park to do the best he could for them as well as himself; they also assisted him. Moreover, by the acceptance of the reference to them in the company's prospectus, they undertook the duty of assisting to float the company by answering the inquiries of persons proposing to take shares in it." 1

$\S 12$. Bagnall v. Carlton. - R. S. Bagnall, J. Nayler, and W. S. Nayler were trustees under the will of James Bagnall, and by the terms of the will were directed to sell a colliery and iron works belonging to his estate.

1 Emma Silver Mining Co. v. Lewis, 4 C. P. D. 396. 
Richard Bagnall, who was tenant for life of the property under the will, promised Duignan, solicitor for the trustees, $£ 1,500$ as commission if he should find a purchaser for the property. Duignan applied to the Messrs. Richardson, and was by them introduced to Carlton. An arrangement was made between Duignan, on behalf of the trustees, and Carlton, that Carlton should form a company to purchase the collieries and business for $£ 290,370$. If Carlton performed his part of the agreement, he was to be paid $£ 85,000$ by the vendors; if he failed, he was to pay $£ 20,000$ as liquidated damages, and this sum was first to be deposited as eaution money. About this time Carlton applied to Grant to join him in the enterprise, and it was agreed between Grant, Carlton, and the Richardsons, that Grant should undertake the whole risk and expense of getting up the company, and should advance Carlton the deposit of $£ 20,000$; and that as compensation for his services he should receive $£ 65,000$ and Carlton $£ 20,000$, out of which the latter was to pay the Ricliardsons $£ 10,000$. This arrangement between Grant, Carlton, and the Richardsons was not disclosed to the trustees or to Duignan, who, on the face of the transactions, dealt with Carlton and the Richardsons. A contract was then executed between the trustees, who agreed to sell the property, and Bytheny, as a trustee on behalf of the intended company, who agreed to buy, for the sum of $£ 290,370$. At the same time a secret contract was made between the trustees and Carlton, whereby it was agreed that Carlton should be paid $£ 85,000$ from the purchase price when received. The company was then registered. The object of the company was stated to be, among other things, the earrying into effect the purchase agreement between the trustees and Bytheny. As soon as the company was established, Grant cireulated 
the prospectus and advertised and recommended the company. The shares were taken by the public, and the company took possession and paid the purchase price of the property. Out of this price Carlton was paid $£ 85,000$ by the trustees, and this sum was divided between the Richardsons, Grant, and Carlton, as had been agreed upon, and Duignan was paid $£ 1,500$ by Richard Bagnall. It was held that the trustees, Grant, the Richardsons, Duignan, and Carlton were promoters. ${ }^{1}$

$\S$ 13. Nant-y-Glo \& Blaina Iron Works Co. v. Grave. Richardson and Carlton were promoters of the Nant-y-Glo and Blaina Iron Works Company, and received certain paid-up shares as a secret commission on a sale of property to the company. Being promoters of the company, they cast about to find other promoters, and a letter was addressed by Mr. Richardson to the defendant, Mr. Grave, in which he explained to him that operation which he then desired to effect for the promotion of the company, and suggested the desirability of having for directors persons whose names would be likely to inspire confidence in the public, and asked him to become a director. $\mathrm{Mr}$. Grave agreed to bccome a director, in consideration, among other things, of receiving fifty of the shares which had been retained by Richardson and Carlton. "I do not think it would be forcing the law of this case in the slightest degree," said Bacon, V. C., "to say, that from the time that letter was received and adopted and acted on, Mr. Grave became as much a promoter of this company as any other person engaged in it." 2

$\S 14$. Twycross v. Grant. - The Duke de Saldanha, a Portuguese nobleman, ambassador to England, had a concession of powers to make and work tramways from

1 Bagnall v. Carlton, 6 Ch. D. 371.

2 Nant-y-Glo \& Blaina Co. v. Grave, 12 Ch. D. 738. 
Lisbon to other places. Desiring to sell this concession, he applied to the defendant, Grant, as a person who would assist him. Grant applied to the other defendants, Clark and Punchard, contractors and persons whose business it was to make such tramways. The arrangements, among others settled, were as follows: that a corporation should be formed ; that Clark and Puncliard should contract with it to construct and equip certain lines of tramway for the sum of $£ 309,810$. Of this sum Clark and Punchard were to gire the Duke $£ 22,000$ in money and shares, Grant $£ 45,800$ for services in obtaining the contract for them and in the formation of the company and raising the capital; and Clark and Punchard were also to qualify the directors, that is to say, to transfer to them or give them the price of shares, free of expense, to such an amount as to qualify them to be directors. The corporation was formed, and its capital raised; directors were found, mainly, if not wholly, by Clark and Punchard; and the contract for the construction of the tramways was made by the corporation with Clark and Punchard. Grant and Clark and Punchard, in a suit subsequently brought against them by subscribers for shares, were held to be promoters. "That the defendants were promoters of the company from the beginning," said Cockburn, Ch. J., "can admit of no doubt. They framed the scheme; they not only provisionally formed the company, but were, in fact, to the end its creators; they found the directors and qualified them; they prepared the prospectus; they paid for printing and advertising, and the expenses incidental to bringing the undertaking before the world." 1

$\S 15$. Lydney \& Wigpool Iron Ore Co. $\nabla$. Bira. - James Bird, a member of a firm of iron merchants consisting

1 Turycross v. Grant, 2 C. P. D. 469. 
of himself and his brother William Bird, entered into an agreement, in behalf of the firm, with the owners of certain iron mines to form and launch a company for the purpose of purcliasing the mines. It was agreed that they should receive a commission of $£ 10,800$ out of the purchase price of $£ 100,000$ which was to be paid by the company for the mines, and should have the conduct of the sale of the company's ore on a two per cent. commission. All the negotiations were conducted by James Bird, and William Bird took no part in them. The latter, however, personally guaranteed the subscription of the capital stock of the proposed corporation. "James Bird," the Court found, "in fact procured the formation of the company. He suggested its formation, he took an active part in the preparation of its prospectus and memorandum and articles of association, in the appointment of two of its first directors, in the appointment of its secretary, and he procured his own firm to be engaged to conduct the sales of the company at a large commission. He fixed the purchase price at $£ 100,000$, and stipulated for the payment of $£ 10,800$ to his own firm, and he procured the payment of that sum by the company, of which he retained $£ 5,800$, paying $£ 5,000$ to William Bird for his guarantee." It was held that he was a promoter. William Bird, it was held, was not a promoter, there being no evidence that he had taken any such part in the formation of the company as to make him accountable to it as a promoter. It did not appear that he knew of the arrangement as to the $£ 10,800$, or that he was in effect to be paid by the company for his guarantee. He had retired from the firm on the day that the company was registered, and the promotion of companies was no part of the business of the firm when he was a member of it. He therefore escaped liability, al- 
though he had received $£ 5,000$ at the expense of the company. ${ }^{1}$

$\S 16$. Mere agreement or intent to promote does not make one a promoter. - It may be important to determine when a promoter becomes or ceases to be such. For example, the liability of a promoter to account to the corporation for a profit secured by him on a sale of his property to the corporation, may depend upon whether he acquired the property before or after he became a promoter. A person becomes a promoter only by taking, directly or indirectly, in the formation or floating of a corporation, some action of such a nature as to impose on him the duty of protecting the interests of the corporation about to be formed, so far as such interests may be actually or constructively in his keeping. ${ }^{2}$ Accordingly an intention, or even an agreement, to promote is not enough.

$\S 17$. Absolute purchase of property with view to resale to projected corporation as evidence of promotership. - The mere purchase of property outright, with intent to sell the same to a corporation to be called into existence to buy it, does not constitute the purchaser a promoter of a corporation which may subsequently be formed and to which the property is sold. The utmost that can be said

1 Lydney \& Wigpool Iron Ore Co. v. Bird, 33 Ch. D. 85. See also South Joplin Land Co. v. Case, 104 Mo. 572; Woodbury Heights Land Co. v. Loudenslager (N. J. 1896), 35 At. Rep. 436.

2 "Something must, it is submitted, be done by the promoter to impose upon him the duty of protecting the interest of those who ultimately form the company. He assumes this duty if he assumes to act for them, or if he induces them to trust him, or to trust persons who are under his control, and who are practically himself, in disguise; he also assumes this duty if he calls the company into existence in order that it may buy what he has to sell; but he does not assume such duty by negotiating with persons who have themselves assumed that duty, and who are in no way under his influence."2 Lindley on Partnership, 585. 
of him is that at the time of his purchase he was the projector of a corporation which he intended to promote. He may or may not become a promoter of the corporation. He may advertise the fact that he has acquired the property, and is willing to sell it to any corporation that chooses to buy it of him; then if any persons sce fit to promote a corporation to make the purchase, they are promoters, but he is no promoter. ${ }^{1}$ On the other hand, he may take such steps in the organization of a corporation for the purchase of his property, as to become a promoter. But it is by taking such steps, and not by the purchase, that he assumes the character of a promoter. ${ }^{2}$

$\S 18$. Illustrative case. - In Ladywell Mining Co. v. Brooks, ${ }^{3}$ the following facts appeared:-

On the 1st of February, 1873, five persons purchased a mine for $£ 5,000$, with the view of reselling it to a company to be formed, but they had at that time taken no steps to form any company. They completed their purchase on the 17th of March, 1873, the purchase price being paid out of their own moneys; and on the 4 th of April, 1873, they entered into a provisional contract with a trustee for the intended company for the sale of the mine to the company for $£ 18,000$. On the 8th of April, 1873, the company was registered under the Companies Acts, its principal object being, as stated in the memorandum of association, the purchase of the mine; and in its articles the contract of the 4th of April, 1873, was adopted and four of the vendors were named as directors; but the contract of the 1st of February, 1873,

1 Bacon, V. C., in Gover's Case, 20 Eq. 122.

2 Gover's Case, 1 Ch. D. 182 ; Erlanger v. New Sombrero Phosphate Co., per Lord Cairns, 3 App. Cas. at p. 1235; Ladywell Mining Co. v. Brooks, 35 Ch. D. 400.

835 Ch. D. 400. 
was not disclosed to the company. The whole of the shares were placed by the vendors, and the share capital $(£ 30,000)$ paid in in cash. At the same time they received $£ 18,000$ from the company as the purchase money for the mine. Subsequently a suit was brought by the company to recover the secret profit made by them on their sale to the company. It was held that the vendors, when they purchased the mine, were not promoters of, or in a fiduciary position towards, the company which was ultimately formed.

$\S 19$. Conditional purchase of property with view to resale to projected corporation as evidence of promotership. - The acquirement of an option to buy property with intent to sell the property to a corporation to be formed, and to fulfil the condition of the option by means of the money or shares of stock received on the sale to the corporation, does not in itself constitute the holder a promoter of a company subsequently formed, and to which the property is sold. And this is so even if the intent of the holder is to avail himself of his option only in the event of a company being formed and capitalized to purchase the property. The fact that he pays or agrees to pay his vendor in shares of the company's stock, is a circumstance to be considered in determining whether or not the purcliase was made for the company, but it is not conclusive. He may sell to the company and take his pay in stock, without becoming a promoter of the company; and this being so, he may properly agree to pay his vendor in such stock. There is no distinction in principle between the absolute title acquired in the case of a purchase outright, and the conditional right acquired under an option. ${ }^{1}$ But in either case, a corporation pro-

1 Gover's Case, 1 Ch. D. 182 ; Plaquemines Tropical Fruit Co. v. Buck, 52 N. J. Eq. 219. 
moted by the purchaser, and to which the property is sold by him, may, under certain circumstances, become entitled to the benefit of his purchase, as will be explained hereafter. ${ }^{1}$

$\S 20$. Promotership not limited to period anterior to organization of corporation. - There is nothing to limit the word "promoters" to persons acting before the company is formed, at least till the share capital is engaged. ${ }^{2}$ The work of promotion may go on in the direction of securing the capital after the company has been incorporated, and the question as to when one who in the outset was a promoter continues or eeases to be so, becomes, therefore, one of fact. This is explained by Chief Justice Cockburn as follows :-

"So long as the work of formation continues, those who carry on the work must, I think, retain the character of promoters. Of course, if a gorerning body, in the shape of directors, has onee been formed, and they take, as I need not say they may, what remains to be done in the way of forming the company into their own hands, the functions of the promoter are at an end. But so long as the promoters are permitted by the directors to carry on the work of formation, the latter remaining passive, so long, I think, would a jury be warranted in finding that what was done by them was done as promoters." ?

$\S 21$. Fiduciary relation of promoters to corporation. - The analogy of the relation of promoter and corporation to that of trustee and cestui que trust is quite close. There may be trusts for unborn persons, enforceable by such persons when they come into existence. But promoters are not technically trustees. Nevertheless familiar principles of

1 See Sect. 55, et seq.

2 Bramwell, L. J., in Twycross v. Grant, 2 C. P. D. 469, 503.

Twycross v. Grant, 2 C. P. D. $469,541$. 
the law of trusteeship have been extended to meet their case; and it is held that a fiduciary relation exists between them and the corporation which they promote. In the opinion of Lord Justice Lindley, it is objectionable to talk of there being a fiduciary relation to a company before the company has any existence. ${ }^{1}$ Yet a non-existent person may sometimes be treated as an existing person, with the same rights in certain respects as if in existence. Take, for example, the case of unborn persons who are represented by a guardian ad litem, and whose consent, through such guardian, is given or withheld to a decree as to the subject-matter of a controversy in which they may become interested. The existence of a fiduciary relation between the promoter and the corporation is fully established by the authorities. "A promoter," declared James, L. J., " is, according to my view of the case, in a fiduciary relation to the company which he promotes or causes to come into existence." 2 " Promoters," said Sir George Jessel, "stand in a fiduciary relation to that company which is their crea-

1 Lydney \& Wigpool Iron Ore Co. v. Bird, 33 Ch. D. at p. 93. "The real relation of promoters to companies," says Lord Justice Lindley, "is difficult to define; the relation is in truth sui generis, and is the result of dealings and transactions of a kind not known until recent times. The term by which accurately to define such relation has not yet been discovered. Familiarity with trusts and the language employed in connection with them has led to the description of the relation as a fidnciary relation, and, although this is not a very happy expression, it is not easy to suggest a better. What is meant, is that although there is no actual relation of trustee and cestui que trust between a promoter and an unformed company, yet that when he has succeeded in forming it, he is liable to it, in respect of frauds practised by him upon it, planned by means of agreements entered into before its formation and the real nature of which is carefully concealed from every one, except those who profit by them. The frauds thus perpetrated are obvious when discovered, and the doctrine of fiduciary relation has been invented or extended in order to defeat them." Lindley's Law of Companies, 5 th ed. 348 .

2. New Sombrero Phosphate Co. v. Erlanger, 5 Ch. D. 73. 
tion." 1 Speaking of the promoters in the well-known case of Erlanger v. New Sombrero Phosphate Co.,2 Lord Cairns said: "They stand, in my opinion, undoubtedly in a fiduciary capacity." In the same case ${ }^{3}$ Lord Blackburn, noting the fact that throughout the Companies Act, 1862, the word "promoters" is not used, said: "Neither does this Act in terms impose any duty on those promoters to have regard to the interests of the company which they are thus empowered to create. But it gives them an almost unlimited power to make the corporation subject to such regulations as they please, and to create it with a managing body whom they select, having such powers as they choose to give those managers, so that the promoters can create such a corporation that the corporation, as soon as it comes into being, may be bound by anything, not in itself illegal, which those promoters have chosen. And I think those who accept and use such extensive powers, which so greatly affect the interests of the corporation when it comes into being, are not entitled to disregard the interests of that corporation altogether. They must make a reasonable use of the powers which they accept from the Legislature with regard to the formation of the corporation, and that requires them to pay some regard to its interests. And consequently they do stand, with regard to that corporation when formed, in what is commonly called a fiduciary relation to some extent."

$\S 22$. Existence of such relation established by authorities. - "The case of a promoter," observes the author of one of the leading English works on corporations, "seems an exceptionally strong case of fiduciary relationship, inasmuch as the trustee or agent, so far from being selected by his

1 New Sombrero Phosphate Co. v. Erlanger, 5 Ch. D. 73.

23 App. Cas. at p. 1236.

8 At p. 1268. 
cestui que trust or principal, here absolutely creates the principal in whose affairs he acts; so that if it could ever be said by a fraudulent agent to a person whom he has defrauded, 'You have only yourself to blame, you should not have trusted me', such an argument would here be excluded, for the company had no choice in the matter as to who should call it into existence." 1 And in Yale Gas Stove Co. v. Wilcox, ${ }^{2}$ the Court said: "That such persons (promoters) occupy a fiduciary relation toward the company or corporation whose organization they seek to promote, is well settled by the decisions of both countries."

$\S 23$. Consequences of fiduciary relationship. - While the promoters are in a fiduciary relation to the corporation, they must, in all their dealings with or for it, act fairly and in good faith. If they undertake to sell property to it, or to make contracts with it, they must not only abstain from misrepresentations, but they must fully disclose all material facts within their knowledge. They cannot deal with it as a stranger could; they are not permitted to make secret profits at its expense, and will be held accountable for such ; and their transactions will be closely scrutinized by a Court of Equity, and set aside for any unfairness or overreaching. Yet, in passing on such transactions, some caution must be employed. "In dealing with any particular case," said Lord Justice Lindley, "care must be taken not to be misled by words. Owing to the ambiguity in the meaning of the word 'promoter,' and the difficulty of defining his exact relation to the company he procures to be formed, it is unsafe to say that any particular person was a promoter of a particular company, and to infer from thence that he is liable to account to it as if he had been its trustee. The question

1 Buckley's Companies Acts, 5th ed. p. 543.

264 Conn. at p. 119. See also Plaquemines Tropical Fruit Co. $\nabla$. Buck, 52 N. J. Eq. 219. 
24 PROMOTERS AND PROMOTION OF CORPORATIONS.

in each case must be, what has the so-called promoter done to make himself liable to the demand against him? What fraud or breach of trust has he committed or been party or privy to? If none, he is under no liability; if any, he is liable accordingly by whatever name he may be called, or by whatever terms his relation to the company may be expressed." 1

1 Lindley's Law of Companies, 5th ed. 349. 


\section{CHAPTER II.}

DUTIES OF PROMOTERS TO THE CORPORATION.

$\S 24$. Duties of promoters in organization of corporation.

25. Erianger $v$. New Sombrero Phosphate Co., 3 App. Cas. 1218.

26. Judgment of Lord Cairns.

27. Exception to rule laid down by Lord Cairns.

28. Promoters must disclose their interest in transactions with corporation.

29. As vendors of corporation not always bound to disclose cost of property to them.

30. Under some circumstances must disclose such cost.

31. Trustees not permitted to make secret profit in matter of trusteeship.

32. Similar rule applies to promoters.

33. Mere declaration that promoter is interested not enough when made to the directors only.
§ 34. Imperial Mercantile Credit Association $v$. Coleman, L. R. 6 H. L. 189.

35. Disclosure of interest only sufficient if made to the shareholders.

36. Full disclosure must be made.

37. In re Westmoreland Green \& Blue Slate Co., 2 Ch. (1893) 612.

38. To whom disclosure must be made and by whom acted upon.

39. Effect of disclosure to, and consent by, all the shareholders representing entire capital stock.

40. Effect of disclosure to and consent by all the existing shareholders, when entire capital stock not issued.

41. Ultra vires acts not validated by disclosure to and consent by all the shareholders.

\section{$\$ 24$. Duties of promoters in organization of corporation. -}

As promoters are bound to act fairly and with good faith in availing themselves of the powers and opportunities accorded to them by the law authorizing the creation of corporations, it follows as a rule that in organizing, or in procuring, through others under their control, the organization of a corporation to purchase or take a lease of their own property or property in which they have an interest, or to enter into a contract in which they are interested, it 
is their duty, so far as they have the power and opportunity, to see that a competent and disinterested board of directors is chosen, in order that the corporation may have proper protection when it comes to a determination of the question whether or not it is expedient for it to enter into the proposed transaction. And it is their duty not only to provide a board of directors who can exercise an independent and intelligent judgment on the transaction, but to see that they do exercise such judgment.

\$ 25. In Erlanger v. New Sombrero Phosphate Co., ${ }^{1}-$ the facts were that a syndicate of which Baron Erlanger, a Paris banker, was at the head, purchased for $£ 55,000$, from the official liquidator of an insolvent company, an island said to contain valuable mines of phospliate. Erlanger, who managed the business of this purchase, proceeded to get up a company to take over the island and to work the mines. He named five persons as directors. Two were abroad; of the three others, two were persons entirely under his control, and were furnished by him with the shares necessary to qualify them for the office. One of these two persons appeared to have acted as a business agent for Erlanger; the other was a private friend of Erlanger. The sale of the island was made, nominally, by a person who had really no interest in the island, and was made to the director who was the business agent of Erlanger, and who appeared as the purchaser for the company. The price was $£ 80,000$ in cash and $£ 30,000$ in paid-up shares of the company. The two directors, with whom, through Erlanger's arrangement, a third person (one entirely uninformed on the subject of the original purchase and the subsequent sale) was associated, assuming to act as directors of the company, accepted, on its behalf, the purchase. The price paid by the syndicate for

13 App. Cas. at p. 1236. 
the island was not disclosed. Subsequently a bill filed by the company to rescind the contract was sustained. "I cannot," said Lord Cairns, "but regard a meeting at which two of the principal directors did not and could not attond, at which one who did attend and take part in the deliberations was at once a person buying and selling, where the legal adviser present and assisting was virtually another vendor, and where the two remaining directors are not shown to have had the means of exercising, or to have exercised, any intelligent judgment on the subject, as little else than a mockery and a delusion."

$\S 26$. Judgment of Lord Cairns. - Lord Cairns laid down the duties of promoters in the position occupied by the promoters in the above case, as follows:-

"They stand, in my opinion, undoubtedly in a fiduciary capacity. They have in their hands the creation and moulding of the company ; they have the power to define how and when and in what shape, and under what supervision, it shall start into existence and begin to act as a trading corporation. If they are doing all this in order that the company may, as soon as it starts into life, become, through its managing directors, the purchaser of the property of themselves, the promoters, it is, in my opinion, incumbent upon the promoters to take care that in forming the company they provide it with an executive, that is to say, with a board of directors who shall both be aware that the property which they are asked to buy is the property of the promoters, and who shall be competent and impartial judges as to whether the purchase ought or ought not to be made. I do not say that the owner of property may not promote and form a joint-stock company, and then sell his property to it; but I do say that if he does he is bound to take care that he sells it to the company through the medium of a board of directors who can and do exercise an independsnt and intelli- 
gent judgment on the transaction, and who are not left under the belief that the property belongs, not to the promoter, but to some other person." 1

§ 27. Exceptions to rule laid down by Lord Cairns. - It is not an inflexible rule, however, that promoters who bring a corporation into existence in order that it may enter into some contract in the subject-matter of which they themselves have a personal interest, must under all circumstances provide the corporation with a disinterested board of directors to guard its interests in the matter. A trustee is not absolutely disqualified from acting in a transaction, because he has an interest therein adverse to that of his cestui que trust. If he acts with the knowledge and acquiescence of the cestui que trust, and is guilty of no deception or unfairness, his acts are valid. Not infrequently in the case of a purchase or contract, promoters act for themselves on the one side, and for the corporation on the other, or the corporation is represented in the transaction by persons controlled by or subject to the influence of the promoters. In such case, their doings are not subject to attack, provided they observe the rule in relation to disclosure, and do not abuse their influence, or practise any unfairness or imposition. $^{2}$ Again, it may not rest with the promoters to nominate the directors. In the majority of cases, perhaps, the cnabling act contemplates that the first directors shall be named by the promoters or corporators, and they are so. named; but in some instances, in the organization of the corporation, the directors are chosen by the subscribers for shares, and when this happens, and the subscribers constitute an independent body, the rule laid down by Lord Cairns is not applicable. The promoters may become the

1 See also Plaquemines Tropical Fruit Co. v. Buck, 52 N. J. Eq. 219.

2 Densmore Oil Co. v. Densmore, 64 Penn. 43. 
original shareholders, owning all the shares of the capital stock; and then the rule is inapplicable. ${ }^{1}$

$\S 28$. Promoters must disclose their interest in transactions with corporation. - The rule as to disclosure requires a statement by the promoters of any interest they may have in a transaction with the corporation. Occupying a double position, where interest may conflict with duty, they must make it known, and must state the nature of that interest. ${ }^{2}$

If the promoters sell, or cause to be sold, to the corporation property purchased by them, or in which they acquired an interest by purchase, when promoters, for the purpose of resale to the corporation, they must disclose. what they paid for it; because the benefit of the purchase belongs to the corporation, and unless the corporation consents to their retaining a profit, they must turn the property in for what they gave for it. ${ }^{3}$

$\S 29$. As vendors of corporation, not always bound to disclose cost of property to them. - When the promoters have purchased or acquired an interest in the property before they begin to promote the corporation, they may, under some circumstances, make a sale to the corporation at an advance, without disclosing the price which they paid. It

1 See Sect. 39. Erlanger v. New Sombrero Co. "is a case which is often quoted and not unfrequently misunderstood. Of course Lord Cairus's observations were directed only to a case such as he had before him, where it was attempted to bind a large body of shareholders by a contract which purported to have been made between the vendor and the directors before the shares were offered for subscriptions, whereas it appeared that the directors were only the nominees of the vendor, who had accepted his bidding, and exercised no judgment of their own." - Lord Davy, in Salomon v. Salomon \& Co.,75 L. T. Rep. at p. 437.

2 Erlanger v. New Sombrero Phosphate Co., 3 App. Cas. 1218.

8 In re Ambrose Lake Tin \& Copper Mining Co., 14 Ch. D. 398 ; Ladywell Mining Co. v. Brooks, 35 Ch. D. 400. 
was so held in Densmore Oil Co. v. Densmore, ${ }^{1}$ the Court saying, through Sharswood, Ch. J.: "Any main or number of men who are the owners of any kind of property may form a co-partnership or association with others, and sell that property to the association at any price which may be agreed on between them, no matter what it may have originally cost, provided there be no fraudulent misrepresentations made by the vendors to their associates. They are not bound to disclose the profit they may realize by the transaction. They were in no sense agents or trustees in the original purchase, and it follows that there is no confidential relation between the parties which affects them with any trust." 2

$\S 30$. Under some circumstances must disclose such cost. It is to be noted that in the above case the fact that the promoters of the corporation were the vendors, was made known, the property was sold to the corporation at a fair price, and there were no circumstances connected with its acquisition by the vendors which rendered knowledge of the anterior price paid by them material. Moreover, the original holders of all the shares acquiesced in the transaction. The cost price of property affords some evidence as to its value, and in some cases it may be of much importance, and a fact which promoters who occupy a fiduciary position and are bound to the exercise of the greatest good faith, ought to disclose. In New Sombrero Phosphate Co. v. Erlanger, ${ }^{3}$ where the promoters sold to the corporation, for $£ 110,000$, an island which they had but a few days

164 Penn. 43. See also Burbank v. Dennis, $101 \mathrm{Cal} .90$.

2 But because they did not occupy a position of trust toward the corporation in their purchase, it does not follow that they were notiu such position on their sale to the corporation. See observations as to this in Taylor on Corporations, 2 d ed. Sect. 83, n. 1. The true grounds for the decision are those indicated in the succeeding section.

85 Ch. D. at p. 112. 
before purchased for $£ 55,000$, Jessel, M. R., said: "I do not think it is absolutely necessary that in all cases the price given should be stated, but looking at the peculiar position of the parties, I think it was necessary here." If the fact that the promoters own the property, or have an interest in it, should be disclosed to the shareholders, it might suffice, without a statement of the anterior price paid by them, when a similar disclosure to the directors of the corporation would be regarded as insufficient. ${ }^{1}$

$\S 31$. Trustees not permitted to make secret profit out of trusteeship. - It is a familiar rule of Equity that a trustee is never permitted to make a secret profit in the matter of his trusteeship. "It is," said Knight Bruce, V.C., "the danger of the commission of fraud in a manner and under circumstances which, in the great majority of instances, must preclude detection, that in the case of trustees, and all parties whose character and responsibilities are similar (for there is no magic in the word), induces the Court (not only for the sake of justice in the individual case, but for the protection of the public generally, and with a view to assert and vindicate the obligation of plain and direct dealing between man and man in all cases, but especially in those where one man is intrusted by another) to adhere strictly to the rule, that no profit of any description shall be made by a person so circumstanced, ... . saying to the person complaining that he has thus employed his time and skill without remuneration, that he has elected so to treat the matter; that he has had his reward, for he has had the possibility, nay, the probability, of retaining to himself that which he never ought to have retained; that

1 See Lord Cairns's observation as to this in Imperial Mercantile Credit Association v. Coleman, L. R. 6 H. L. at p. 206. 
he has been willing to run the risk, and cannot complain if he happens to lose the stake." 1

\$ 32. Similar rule applies to promoters. - This rule is generally applicable to promoters. Consequently, it is their duty to disclose to the corporation the nature and amount of any profit or remuneration, whether in money, shares, or otherwise, which they are to receive, in connection with the promotion of the corporation, or in consideration of services rendered by them in the course of such promotion. The promoters are as a rule entitled to retain the profit or remuneration only when the corporation has assented thereto after such disclosurc. ${ }^{2}$

$\S 33$. Mere declaration that promoter is interested not enough when made to directors only. - The requirement as to disclosure is not satisfied by a mere declaration by the promoter that he has an interest or that he is to obtain a profit arising out of or in connection with the promotion of the corporation. He must state the nature of his interest, the amount he is going to receive. At least this is so when the disclosure is made, not to the shareholders, but to the directors, and the consent of the corporation is given by the directors.

\$34. Illustrative case. - Thus, in Imperial Mercantile Credit Association v. Coleman, ${ }^{3}$ the plaintiff corporation was formed for the purpose of carrying into effect loans and other financial operations. The defendant, Coleman,

1 Benson v. Heathorn, 1 Y. \& C. 326.

2 Bagnall v. Carlton, 6 Ch. D. 371 ; Emma silver Mining Co. v. Grant, 11 Ch. D. 918 ; Emma Silver Mining Co. v. Lewis, 4 C. P. D. 396 ; Whaley Bridge Calico Printing Co. v. Green, 5 Q. B. D. 109 ; Lydney \& Wigpool Iron Ore Co. v. Bird, $33 \mathrm{Ch} . \mathrm{D} .85$; In re Westmoreland Green \& Blue Slate Co., 2 Ch. (1893) 612; Chandler v. Bacon, 30 Fed. Rep. 538; Yale Gas Stove Co. v. Wilcox, 64 Conn. 105 ; McElheney's Appeal, 61 Penn. 188.

8 L. R. 6 H. L. 189. 
who carried on business as a stockbroker, was a director. Having entered into an arrangement with the contractors of a certain railway company to place its debentures for a commission of five per cent., he proposed, at a meeting of the directors of the plaintiff corporation, that the corporation should place the debentures at a commission of one and one-half per cent. In doing so he stated that he had an interest in the transaction, but was silent as to the arrangement which he had made with the contractors. The proposal was adopted, and debentures to a very large amount were placed by the corporation. It was held that inasmuch as his fellow-directors might have been under the impression that he merely took his ordinary commission as a stockbroker, and thereupon confirmed the transaction, he was liable to refund all his profits, because it turned out that he had made a large and extraordinary profit, beyond the usual commission of a stockbroker; and it was decided that he was compellable to statc not only that he had an interest, but what interest it was, before he could sustain the transaction.

$\S 35$. Disclosure of interest only, sufficient if made to the shareholders. - It would seem that if promoters disclose to the stockholders the fact that they are to receive compensation or profit in the promotion of the corporation, and the stockholders assent thereto, the disclosure will be sufficient. Apparently, under such circumstances, it is not necessary that the amount of the profit or compensation should be stated. In the case above referred to, it was contended, on the defendant's behalf, that having stated at a dircctor's meeting that he had an interest in the transaction under consideration, it was open to the directors who were there present to have cross-questioned him, and to have elicited from him what his interest really was. Commenting on this, Lord Cairns said: "If this had been a case 
in which a person standing in a fiduciary relation to another had, in the presence of another, stated that he had an interest, and that other was able to ask some further questions as to what his interest was, I should have thought a good deal of weight might be attributed to this argument. But it was not to the company, or even to a general meeting of the company, that Mr. Coleman stated that he had an interest. It was to some other persons, who were just as much in a fiduciary position as he was himself, and in my opinion it was not open to Mr. Coleman . . merely to state to those other trustees what might have led them to make further inquiry, but to leare it open to the chance of whether they would make that inquiry or not." 1

\$ 36. Full disclosure must be made. $-\mathbf{A}$ provision in the articles of association that the validity of a stated transaction with the company shall not be impeached on the ground that the promoters are interested therein, does not obviate the necessity of full disclosure, by the promoters, of their position and interest in respect to such transaction.

$\S 37$. In In re Westmoreland Green and Blue Slate Co., ${ }^{2}-$ Poole and Binns were working a quarry in partnership. Poole had the option of taking a lease of another quarry known as Stone Dykes. Wishing to form a company to work these quarries, they employed Ashworth and Bland to assist them in getting up the company. On the 16th of February, 1886, Poole, Binns, Ashworth, and Bland entered into an agreement, in which they were called the vendors, with a trustee for the intended company, to hand over the quarries to the proposed company. It was agreed that the vendors should sell, and the company should purchase,

1 Imperial Mercantile Credit Association v. Coleman, L. R. 6 H. I. at p. 206.

22 Ch. (1893) 612. 
"the interest of the vendors in Stone Dykes under the lease," in addition to other properties, and that Bland and Ashworth should each receive 120 of the paid-up shares issued by the company in part payment of the purchase price. On the same day a lease of Stone Dykes was granted to the four promoters. The articles of the company referred to this agreement and provided that the directors should adopt it on behalf of the company, with or without modification. The fourth article was as follows: "The validity of such agreement shall not be impeached on the ground that the directors of the company or any of them are interested therein as vendors or otherwise, or that they are the promoters of the company, nor shall they be accountable for the benefits secured to them, or which they or any of them may obtain under such agreement, and every member shall be deemed to have had notice of the terms of such agreement and to.approve and sanction the same, modified or not as the case may be."

In accordance with the agreement the quarries were transferred to the company, and Bland and Ashworth received their shares. Subsequently, in the winding up of the company, Bland was compelled to contribute to the company's assets the par value of the shares received by him. The Court, holding that the transaction in question was an attempt to evade the law as to secret profits, Bland and Ashworth not being real vendors, said : "Is there anything in the articles to protect the transaction? Article 4 is relied on by the appellant, and its words are very wide. But though Poole, Binns, Ashworth, and Bland knew all the facts of the case when the directors passed a resolution for adopting the agreement, what did the company know? The company knew that Bland and Ashworth were among the lessees of Stone Dykes, but they did not know that making them lessees was merely machinery to obtain for 
them payment for their services. This prevents the appellant from claiming protection under the 4th article."

\$38. To whom disclosure must be made and by whom acted upon. - Facts which it is incumbent upon promoters to disclose to the corporation are sufficiently disclosed if communicated to a competent and disinterested board of directors, or, when the directors are interested or are under the control of the promoters, if communicated to the shareholders. There must ordinarily be an independent board or body of shareholders to receive and act upon the information. ${ }^{1}$ But if the facts are made known through prospectuses or otherwise, and the public then, with notice, come in and subscribe for the shares, it will suffice. ${ }^{2}$

$\S 39$. Effect of disclosure to and assent by all the shareholders representing entire capital stock. - It is no objection that the shareholders to whom disclosure is made and who acquiesce in the transaction, do not constitute an independent body, provided the entire capital stock of the corporation has been issued and is held by such shareholders. In such casc the assent of all the shareholders is the assent of the corporation, and subsequent shareholders will not be heard to complain, unless the transaction was ultra vires the corporation. ${ }^{3}$ Thus in Parsons v. Hayes, ${ }^{4}$ a mining corporation was formed under the general laws of the State of New York, with an authorized capital of $\$ 2,000,000$. The

1 Erlanger v. New Sombrero Phosphate Co., 3 App. Cas. 1218; In re Fitzroy Bessemer Steel Co., 50 L. T. Rep. N. s. 144; Simons v. Vulcan Oil Co., 61 Penn. 202.

2 Densmore Oil Co. v. Densmore, 64 Penn. 43.

3 Salomon v. Salomon \& Co., 75 L. T. Rep. 426; In re Ambrose Lake Tin \& Copper Mining Co., 14 Ch. D. 390 ; In re Gold Co., 11 Ch. D. 701; Parsons v. Hayes, 14 Abb. N. C. 419 ; Seymour v. Spring Forest Cemetery Association, 144 N. Y. 334; Densmore Oil Co. v. Densmore, 64 Penn. 43 ; Higgins v. Lansingh, 154 Ill. 331; Foster v. Seymour, 23 Fed. Rep. 65.

414 Abb. N. C. 419. 
directors named in the certificate of incorporation issued paid-up certificates for the entire capital stock, in payment for a mine which they had purchased in behalf of the corporation for $\$ 2,000,000$, but which in reality and to their knowledge was worth less than $\$ 150,000$. Of the stock thus issued, they received as a gift from the vendor of the mine a certain number of shares, in accordance with a previous arrangement. These shares were subsequently acquired by an innocent purchaser, who, upon learning all the facts, brought a shareholder's bill against the corporation and the directors who had authorized the original issue of stock. It was sought by the bill to compel the individual defendants to account to the corporation either for the difference between the value of the mine and the nominal value of the shares issued in payment therefor, or for the profits which they had obtained from the sale of the shares given to them by the vendor of the mine. It was held that as the acts complained of were done with the consent of the holders of the entire capital stock, neither the corporation, nor its shareholders, could complain. "The vendor of the property," observes Mr. Morawetz, commenting on the decision, " in truth took back what he gave. He placed the property in the corporate name, and at the same time practically became the corporation by becoming its sole stockholder. Evidently, therefore, no person was injured by that transaction. If subsequent transferees of shares were deceived by the false representations that the amount of the shares had in fact been paid into the treasury of the company, their claim should have been for the damages caused to themselves individually through the false representations, and not for an infringement of the collective or corporate rights of all the shareholders." 1

1 Morawetz on Corporations, Sect. 290. And if the corporation is a real one, and not a fiction or a myth, there is, in the absence of 
$\S 40$. Effect of disclosure to and assent by all the existing shareholders, when entire capital stock not issued. - Even when the entire capital stock has not been issued, if disclosure is made to the existing shareholder's, and it is their honest intention at the time not to take in new members, it cannot be said that there is any secrecy or want of communication of facts, although shareholders may subsequently come in without notice. Thus in In re British Seamless $P a$ per Box Co., ${ }^{1}$ a company was formed with an authorized capital of $£ 50,000$, and patents and machinery were transferred to it in consideration of shares to the amount of $£ 32,000$. The vendors transferred certain of the shares thus received by them to four of the directors. The rendors and the director's, who were the promoters of the company, and who with the solicitor assented to what was done, were then the only shareholders of the company. They did not issue a prospectus, nor did they invite other persons to take shares, and it was not their intention to take in any other members. Subsequently the company needed more capital, and shares were issued and disposed of to third persons who, upon the failure of the company, alleged that they were not informed of the manner in which the original shares had been allotted. It was held, in the winding up, that the official liquidator, as representing the company, could not call upon the directors to account for the shares which they, had received from the company's vendors. ${ }^{2}$

$\S 41$. Ultra vires acts not validated by disclosure to and assent by all the shareholders. - The rule stated as to the

fraud, no liability to corporate creditors. See the recent important case, Salomon v. Salomon \& Co, 75 L. T. Rep. 426, reversing $2 \mathrm{Ch}$. (1895) 323. For a discussion of the question of liability to corporate creditors, see Cook on Stockholders, Sects. 46, 47.

117 Ch. D. 467.

${ }^{2}$ See also Stewart v. St. Louis \& Fort Scott R. R. Co., 41 Fed. Rep. 736; St. Louis \& Fort Scott R. R. Co. v. Tiernan, 37 Kan. 606. 
effect of acquiescence by the original sharcholders is not applicable when the transaction brought in question is ultra vires the corporation. The unanimous consent of all the shareholders cannot validate such a transaction as against a subsequent dissenting shareholder. ${ }^{1}$ In Mann v. Edinburgh Northern Tramways Co., ${ }^{2}$ the company named was formed under a private Act of Parliament, for the purpose of introducing a system of tramways into Edinburgh, and entered into an agreement with a corporation called the Cable Corporation for the construction of its lines, for the sum of $£ 93,000$, the Cable Corporation undertaking to defray the expenses of obtaining the Act of Parliament. This agreement was negotiated by Mann and Beattie, in bchalf of the Tramways Company, Mann being its solicitor and Beattie its enginecr, and both its chief promoters. At the same time, Mann and Beattie entered into an agreement in their own behalf with the Cable Corporation, by which they themselves undertook, in consideration of the payment to them by the Cable Corporation of the sum of $£ 17,000$, to defray all the expenses of obtaining the Act. The $£ 17,000$ was paid to them by the Cable Corporation from the $£ 93,000$ received by that company from the Tramways Company ; but, as matter of fact, the expenses of obtaining the Act were considerably less than $£ 17,000$, and Mann and Beattie secured a large profit from the transaction. The Act itself provided that the capital of the Tramways Company should be expended in making a cable tramway, the only other expenditure authorized being the cost of procuring the Act. No power was conferred upon the company to spend any of its assets, except for the purposes of the

1 Society of Practical Knowledge v. Abbott, 2 Beav. 559 ; Mann v. Edinburgh Northern Tramways Co., 68 L. T. Rep. N. s. 96 ; In re George Newman \& Co., 1 Ch. (1895) 674.

268 L. T. Rep. N. s. 96. 
Act. It was not within the power of the company to permit Mann and Beattie to retain any surplus after discharge of the expenses of securing the passage of the Act; and the agreement between them and the Cable Company was only a circuitous way of taking such surplus from the funds of the Tramways Company. It was held in the House of Lords that Mann and Beattie were liable to account to the company for their profit, and that they were not relieved by the fact that their agreement with the Cable Corporation was known to all the shareholders of the Tramways Company, and had been ratified by the directors. No approval by those who happened to be directors and shareholders at the time, it was held, could give validity to it, it being ultra vires the company. 


\section{CHAPTER III.}

ACCOUNTABILITY OF PROMOTERS TO THE CORPORATION FOR PROFITS, GIFTS, AND COMMISSIONS.

Article I. - Accountability of Promoters for Profits obtained by them as Vendors of the Corporation.

ARTICLE II. - Accountability of Promoters for Gifts and Commissions.

Article I. - Accountability of Promoters for Profits obtained by them as Vendors of the Corporation.

$\$ 42$. Right of corporation to claim benefit of purchase made by promoters while such.

43. Tyrrell $v$. Bank of London, 10 H. L. C. 26.

44. Mere fact that property purchased by promoters while such does not entitle corporation to benefit of purchase.

45. Benson v. Heathorn, 1 Y. \& C. 326 .

46. Right of corporation to claim benefit of purchase made by promoter before he became such.

47. In re Ambrose Lake Tin and Copper Mining Co., $14 \mathrm{Ch}$. D. 390 .

48. Ladywell Mining Co. $v$. Brooks, 35 Ch. D. 400.

49. Colorable transfer of property to promoter to be by him sold to the corporation.

50. Whaley Bridge Calico Printing Co. $v$. Green, 5 Q. B. D. 109.

51. Acts and declarations of promoter giving corporation right to claim benefit of purchase made by him.

52. Simons v. Vulcan Oil Co., 61 Penn. 202.
§53. Burbank v. Dennis, $101 \mathrm{Cal}$. 90.

54. Right of corporation to benefit of optional purchase made by promoter before becoming such.

55. Offer by promoter to corporation entitling it to benefit of his purchase.

56. Plaquemines Tropical Fruit Co. $v$. Buck, 52 N. J. Eq. 219.

57. Pittsburg Mining Co. v. Spooner, 74 Wisc. 307.

58. Right of corporation to benefit of optional purchase made by third persons confederating with promoter.

59. Fountain Spring Park Co. $v$. Roberts, 92 Wisc. 345.

60. Right of corporation to recover the profit mare by promoter on a sale of his property to it. Definition of term "profit."

61. Recovery of profit when property sold is a commodity having a current market price.

62. Recovery of profit when property sold is not a commodity with current market price. 
$\$ 42$. Right of corporation to claim benefit of purchase made by promoters while such. - A promoter who sells to the corporation he promotes property which he purchased while a promoter, and which at the time of his purchase was available for the purposes of the corporation, is, as a rule, liable to account to it for the difference between the cost and the sale price, unless he has, prior to the sale, disclosed to it his interest and the price which he paid. When he purchases, he is in a fiduciary relation to the projected corporation; he is in a position akin to that of an agent, and is subject in the matter to similar duties. ${ }^{1}$ Although not in fact an agent to buy for the corporation, his relation to it, and his peculiar means of knowledge as to its needs, make it incumbent upon him not to take a position antagonistic to its interests. As in the case of an agent, he will not be permitted to abuse his influence or to betray the confidence reposed in him. It makes no difference that an agent was not directed by his principal to purchase. If he has by means of his position as agent acquired knowledge that his principal desires to buy specific property, he will not be allowed to employ that knowledge to obtain a profit at the expense of his principal, and if he buys the property and then resells it to his principal at an advance, he will be held to have bought for his principal, and will not, without the principal's consent, be permitted to retain any profit. ${ }^{2}$ Under such conditions he is constructively in the same position as an agent directly instructed to purchase for his principal. "If a man is instructed as agent for another to buy property, whatever price he buys it for, he must

1 Gover's Case, 1 Ch. D. 182; Erlanger v. New Sombrero Phosphate Co., 3 App. Cas. 1218 ; Ladyivell Mining Co. v. Brooks, $35 \mathrm{Ch}$. D. 400 ; South Joplin Land Co. v. Case, 104 Mo. 572.

2 Gower v. Andrew, 59 Cal. 119; Davis v. Hamlin, 108 IIl. 39. 
hand it over at that price to his principal, and he cannot as between himself and his principal, when he bought at a lower price, add to it by pretending to sell to his principal that which he has already bought for his principal." 1

$\S 43$. In Tyrrell $\nabla$. Bank of London, ${ }^{2}-$ Read was the owner of an option to buy certain properties. Tyrrell was one of the promoters of the company and acted as its solicitor during its promotion and after its formation. Prior to the actual formation of the company, but while Tyrrell was acting as promoter and solicitor, he entered into an agreement with Read by which he became jointly and equally interested with him in the option. The company, upon its organization, agreed to treat with Read for the purchase of the property, and committed the conduct of the treating to its solicitor, Tyrrell. Ultimately, it purchased the property at the advice of Tyrrell, who carefully concealed from it his interest in the property. Held, that he must account to the company.

$\S 44$. Mere fact that property purchased by promoters while such does not entitle corporation to benefit of purchase. The mere fact, however, that the property which the promoter has sold to the corporation was purchased by him while a promoter, cannot in all cases confer on the corporation the right to claim the benefit of the promoter's purchase. If the corporation was not formed to acquire that particular property, and the promoter purchased without any intimation or assurance that the corporation would take or need it, and not as a speculation from which he might derive secret profits, there would seem to be no reason for holding that he bouglit as a constructive agent,

1 Cotton, L. J., in Ladywell Mining Co. v. Brooks, $35 \mathrm{Ch}$. D. at p. 413; Parker v. Nickerson, 112 Mass. 195.

210 H. L. C. 26. 
or that the corporation was entitled to the benefit of his purchase. $^{1}$ But if, in selling to the corporation, he concealed his interest, and secured a secret profit, it would be difficult to escape the conclusion that when lie purchased, he did in fact purchase in order that he might unfairly obtain a personal benefit at the expense of the corporation.

$\S 45$. Thus in Benson v. Heathorn, ${ }^{2}$ - the defendant being a director of a corporation established for the building, purchasing, hiring, and employment of steam vessels, purchased a vessel, and afterwards sold it, at an advance, to the corporation as from a stranger. In ordering him to account to the corporation, Knight Bruce, V. C., said: "Under these circumstances, is it possible for me, whatever may have been the secret intentions of Mr. Heathorn's mind when he bought the vessel - is it possible for a judge in a Court of Equity to hear him say that he bought it otherwise than as agent? I find it utterly impossible to do so; his own mode of proceeding has, in my opinion, indelibly and inextricably fixed him with the character of agent from the beginning of that transaction."

$\S 46$. Right of corporation to claim benefit of purchase made by promoter before he became such. - When a promoter sells to the corporation property which he purchased before he became a promoter, the corporation, as a rule, cannot, although he fails to disclose to it his interest, claim the benefit of his purchase. Buying for himself with his own funds, before any steps are taken to promote a corporation, he is, in making the purchase, in no sense a trustee or agent for the corporation. Neither in fact nor in contemplation of law is there at the time of purchase a cestui que trust or

1 Sandy River R. R. Co. v. Slubbs, 77 Me. 595.

21 Y. \& C. 326. 
principal for whom it is his duty to buy. His rights in relation to the proceeds of any sale he may make of the property are the same as if the property had been given to or inherited by him. 'The corporation has no greater right to insist on having the property at the price at which he bought, than it would have to claim the property for nothing, in case he had acquired it as a gift. He may be responsible in damages to the corporation for a breach of his fiduciary duty to it, as a promoter, to disclose his interest in the property upon its sale to the corporation, ${ }^{1}$ and it is perhaps a debatable question whether, when he has failed to disclose his interest, he is not liable to hand over to the corporation his profit, - that is to say, the difference between the value of the property at the time he sold, and the price which he received; but he is not ordinarily accountable to the corporation for the difference between what he paid and the price at which he sold. ${ }^{2}$

$\S 47$. In re Ambrose Lake Tin \& Copper Mining Co. - The rule stated in the preceding section is clearly explained in In re Ambrose Lake Tin \& Copper Mining Co. ${ }^{3}$ In this

1 See liability of promoters in damages to the corporation, infra.

2 Ladywell Mining Co. v. Brooks, 35 Ch. D. 400 ; Erlanger v. New Sombrero Phosphate Co., 3 App. Cas. 1218, per Lord Cairns; In re Ambrose Lake Tin \& Copper Mining Co., 14 Ch. D. $390 ;$ In re Cape Breton Co., 29 Ch. D. 795; Densmore Oil Co. v. Densmore, 64 Penn. 43; Ely v. Hanford, 65 Ill. 267; Higgins v. Lansingh, 154 Ill. 301, 378; Burbank v. Dennis, 101 Cal. 90 ; In re The Hess Mfg. Co., 21 Ont. App. 66.

In Getty v. Devlin, 54 N. Y. 403, and Ex-Mission Land \& Water Co. v. Flash, 97 Cal. 610, expressions may be found supporting a view contrary to that expressed in the text; but it will be found that in these cases the corporation became entitled to the benefit of the original purchase by reason of the subsequent acts and declarations of the purchaser in relation to the property, and not merely because the purchaser, subsequent to his purchase, became a promoter of a corporation and sold the property to it.

814 Ch. D. 390. 
case officers of a corporation who liad sold to it a mine which they had purchased before they became officers, werc ordered to account to the corporation for the difference between the cost of the mine to them and the price which they received on its resale. The order was reversed. on appeal.

Cotton, L. J., said: "The principle of the order must be this, that the company are at liberty to treat these persons as trustees of the property for the company, and, treating them as trustees, to allow them only what they paid for the property, and if they got anything else out of the coffers of the company, to make them account for that. Neither on principle nor on authority can that be maintained, unless at the time when the so-called vendor acquired the property he either acquired it for the company, or was in such a position of fiduciary relation to the company that any purchase made by him of property available for the company must be considered as a purchase made by him as a trustee for the company. In that case, what the Court does is to go back to the original purchase made by the person who afterwards purports to sell to the company at an advanced price, and to say, 'This was already the company's at the price which you originally gave for it when you were a trustee for the company. That price you are entitled to receive out of the coffers of the company, and anything else is a sum paid to you for nothing, which you are not entitled to retain." After stating that when the original purchase was made, the purchasers were not trustees for the company, that the suggestion is that they sold to the company, being botl owners of the mine and trustees of the company, and that therefore the company, not seeking to set aside the transaction, may say, "We will take this at its face value, and make you account for the difference," he continues :- 
"How can that be done? I can quite understand an action to set aside the contract altogether, but that is not the course adopted by the company. I can see no ground, either on principle or authority, on which the company can say, not secking to set aside the contract, "We will hold you as passing this to the company, not because you originally acquired it for the company, but because you entered into a contract to sell to the company which is not binding, and therefore we make another contract to take it from you for what it originally cost you, making you account for whatever else, under that invalid contract, you stipulated should be paid for it.' I am of opinion that this cannot be maintained, and therefore the order we have to deal with cannot stand."

§ 48. In Ladywell Mining Co. v. Brooks, ${ }^{1}$ - a lease of a mine was purchased by four persons for $£ 5,000$, and paid for out of their own moneys. At the time of the purchase they contemplated the formation of a corporation to which to sell the lease of the mine. About two months afterwards, they began to promote a corporation, and entered into a contract with a trustee for the intended corporation for the sale of their interest in the mine at the price of $£ 18,000$. The company was formed with three of the four purchasers as directors, and the sale was carried out by. them, their interest not being disclosed. It was held that the corporation was not entitled to the benefit of their purchase, and that they were not liable to refund to it their profits.

"The question is," said Lopes, L. J., " Did Palin and his associates, on the 1st of February, stand in a fiduciary position towards this company that was thereafter to be formed, - or, in other words, were they then acting for the company about to be formed? If they were, the plaintiffs are entitled to succeed. Now this is entirely a question of 
evidence, and the Court has to place upon the evidence which is laid before it its proper effect and meaning. The evidence, after very careful consideration of it, does not satisfy me that Palin and his associates were acting on the 1st of February for the company about to be formed. According to my view, and the view that ought to be drawn from this evidence, they bought the mine themselves and paid for it out of their own pockets, no doubt with the intention of selling to a company thereafter to be formed; but there is nothing to show that they were on the 1st of February acting for a proposed company. No person is called to say that they were asked to take shares by any of the vendors because they were forming a company. There is no evidence that, in any shape or way, they stood in such a relation to the company thereafter to be formed as would eutitle that company, when formed, to say, 'You made this contract for us, - it is our contract, and we can only be required to pay the price which you, acting as our agent, paid for it.' There is no evidence that can properly lead the Court to such a conclusion."

$\S 49$. Colorable transfer of property to promoter, to be by him sold to the corporation. - If the owner of property, as a part of a scheme to sell it to a corporation to be formed, nominally conveys the title to another for a price stated, which is fictitious, in order that this fictitious price may be held out as a price actually paid, and the corporation thus induced to give more than it otherwise would, it being secretly agreed that the real owner shall have the avails of the sale, and pay therefrom to his associate a commission; and then this associate promotes a corporation to which the property is sold, the transfer to him, being a mere sham, is not to be regarded as a purchase by him before he began to promote, and the corporation may recorer from him his secret commission or profit; but it cannot 
recover from the real owner, although he joins in promoting the corporation, the difference between what he paid for the property and what he got on the sale to the corporation. ${ }^{1}$

$\S 50$. Thus, in Whaley Bridge Calico Printing Company v. Green, ${ }^{2}$ - Robert E. Green was the owner of certain calico printing works which he had purchased for the sum of $£ 15,000$. Shortly after the purchase, he pretended to sell the works to his manager, John Smith, for $£ 20,000$, by a contract which the jury found was a sham contract, and which was intended to be used for the purpose of negotiating with a corporation to be formed to purchase the works. It was secretly agreed between Green and Smith, that the latter should have $£ 3,000$ out of the purchase money to be paid for the property by the corporation. The plaintiff corporation was then formed by Green and Smith, and the works transferred to it for $£ 20,000$. The board of directors consisted of their nominees, "and in order to make the purchase run more smoothly, a sham contract of purchase was flashed before the eyes of the directors as if it were a real contract by both Smith and Green." Smith had a right to agree with Green that he should be remunerated to the extent of $£ 3,000$, provided such agreement was made with the knowledge and assent of the corporation; but the corporation had a clear right, it was held, to treat all profit made by Smith out of such a transaction as profit belonging to it. The claim put forward by the corporation to have refunded to it the $£ 5,000$, the difference between the $£ 20,000$ purchase money, and the price at which Green himself had bought, was not sustained. ${ }^{3}$

1 The real owner might be, however, by reason of his participation in the fraud, liable in damages to the corporation.

25 Q. B. D. 109.

${ }^{8}$ See also In re Westmoreland Green \& Blue Slate Co., 2 Ch. 
$\S 51$. Acts and declarations of promoter giving corporation right to claim benefit of his purchase. - One who has purchased and paid for property, prior to any steps to promote a company to take it off his hands, may, by his acts and declarations in his subsequent relation of promoter of the company, make it his duty to treat the property as property bought for the company, and not for himself alone. While such duty may not have been incumbent upon him in making the purchase, it is open to him to assume it if he sees fit, and if he voluntarily takes that position, he will be held to it. $\mathrm{He}$ assumes the duty when he declares that he bought for the company, and persons are induced to join the corporate enterprise on the faith of his declaration. The company is then entitled to the benefit of his purchase. The same result follows if subscribers come in on his assurance that the company is to acquire the property at its cost. In these cases, he is accountable to the company for any secret profit he may obtain. ${ }^{1}$

\$ 52. In Simons v. Vulcan Oil Co., ${ }^{2}$ - the defendants purchased oil lands with a view to selling them to a corporation which they then had it in their minds to form.

(1893) 612, where a transfer of an interest in property was held to be merely a device to evade the law as to promotion money.

1 In Ladywell Mining Co. v. Brooks, 35 Ch. D. at p. 411, Cotton, L. J., puts this case, by way of illustration, in which the benefit of a purchase of property, to be sold to a projected company, might be claimed by the company when formed: "If in fact those who purchased this mine had before the time they made the purchase invited the public to come in and join the company to work this mine, then it may well be that if the company was formed, and they had handed over the mine to the company, the shareholders would have been entitled to say, 'As you have formed a company to work this mine, you must admit that the purchase was not made in your individual capacity, but was made for the purpose of offering it to the public if they came in and formed a company to work it." "

261 Penn. 202. 
The title was taken in the name of the defendant Simons, and in the deeds the total consideration was expressed to be $\$ 81,000$, when in fact it was but $\$ 10,000$. The defendants, with others, then organized the Vulcan Oil Company, and the property was turned in to it for $\$ 81,000$, on their representations, orally and by prospectuses, that they had purchased it for the company, and were conveying it to the company at its original cost. They were held liable to account to the company for the difference between the price at which they bought and the price at which they sold. The case turned on the question whether or not it was the duty of the defendants to treat the property as bought for the company. This was left to the jury to decide as a question of fact, and was decided in the affirmative. The learned trial judge (Judge Hare), among other things, instructed the jury as follows:-

"In order to judge whether this title was acquired by the defendants for themselves, or on behalf of the corporation, we must turn from the deeds (of the property) to the acts and declarations of the parties in the relation in which they stand to the corporation, and see whether looking at what they said and what they did, it does or does not appear that they bought the land in a way rendering it their duty to treat it as land bought for the company, and therefore to be transferred to the company at the price paid to the original owners, unless the contrary was agreed upon with a full knowledge of all the circumstances." (Evidence recited.) "This is the evidence that these lands were in fact purchased by the defendants, ostensibly for the Vulcan Oil Company; and if they represented this to be so; if they held it out to the world as the true state of the case, and induced persons to subscribe on the faith of their declarations; 
if they so dealt with the company and obtained their price, - what their real purpose or object was is inmaterial, because it is impossible to read the secret purposes of men, and in dealing with them we can only look at what they avow. It is possible that their secret and avowed purposes were at variance with each other; their secret purpose was to buy the land for themselves as their own property, with a view of transferring it to the company at an advance; their avowed purpose, to hold it as the property of the company with a view of obtaining subscribers for the stock; but unless this secret purpose was made known, it ought not to avail against the purpose which was proclaimed and by which they were believed by others to be actuated."

§53. In Burbank v. Dennis, ${ }^{1}$ - the defendant Sanborn purchased certain lands and procured contracts for the purchase of other lands, with a view to reap a profit by bringing about the formation of a corporation which should buy the lands at an adrance over the prices paid or contracted to be paid by him. In the negotiations as to some of the lands in question, the defendant Dennis acted as an agent for Sanborn, and also for the owners. It was the intention of Sanborn to induce Eastern capitalists to become subscribers for the stock of the contemplated corporation; but Dennis having suggested to him that home capitalists would interest themselves in the venture, attention was turned toward the latter class, and Dennis, with the co-operation of Sanborn, had negotiations with rarious persons, which culminated in a written agreement. In this agreement, - which was drafted by Sanborn, - Dennis, Sanborn, and the prospective shareholders of the proposed corporation, in consideration of one dollar receired each from the other, agreed to purchase the lands for $\$ 537,000$, and forth- 
with to organize a corporation through which to carry out the enterprise. The interest of each party to the instrument was specified, Sanborn taking one quarter, and Dennis one-fifth. When this instrument was signed, Sanborn and Dennis agreed with their associates that all lands they then had, or had a right under their contracts to acquire, should be turned in to the corporation when formed, at the prices they had paid or agreed to pay. The corporation was then organized, and on the representation of the defendants that $\$ 200,000$ would be required to make first payments and to keep alive Sauborn's options and contracts, that sum was paid in by the subscribers and turned over to Dennis to apply in the manner stated. Subsequently, Dennis reported that he had paid $\$ 193,662.62$ to Sanborn on account of the purchase price of the lands. In truth, but $\$ 97,6066.62$ was required and was applied to pay the cost price; and the balance was retained by the defendants as a secret profit. It was held that, as promoters of the corporation, they must, on the facts stated, account to the corporation for this secret profit. Sanborn purchased the lands, either absolutely or conditionally, prior to his becoming a promoter, and, under ordinary conditions, the corporation would not have been entitled to the benefit of his purchases, but by his declarations, on which the corporation acted, he made himself a trustee for it, as of the time when he bought. ${ }^{1}$

$\S 54$. Right of corporation to benefit of optional purchase made by promoter before becoming such. - The general rule laid down that a promoter who obtains a seeret profit

1 Ex-Mission Land \& Water Co., 97 Cal. 610, is, on the facts therein found, within the principle on which Burbank v. Dennis and Simons $\mathbf{v}$. Vulcan Oil Co. were decided, although the Court seemed to think that promoter vendors of a corporation are liable to account for secret profits on a sale of property to the corporation, whether they acquired the property prior or subsequent to becoming promoters. For a statement of the facts in this case, see Sect. 8 . 
on the sale by him of property which he acquired before he began to promote is not accountable for the difference between what he paid and what he received, is settled when the purchase is outright or absolute. There is some difference of opinion as to its application when a mere option to buy is secured, which is to be exercised only in the erent of a company being formed and capitalized to purchase the property from the lolder of the option. The opposing views are set forth with great clearness in Gover's Case, ${ }^{1}$ in which the circumstances were, in the language of one of the judges, as follows:-

"Mr. Skoines was the patentee of an invention relating to gas-lighting. Mr. Mappin appears to have thought that it was a thing which he could sell at a very high price, to a joint-stock company which he might be able to form for the purpose of buying and working the patent. He thereupon bargains with Mr. Skoines, and in consideration of $£ 1,000$ paid down, he obtains from Skoines a contract binding the latter, for a certain further price in money and paid-up shares in a company to be formed, to convey his patent right. If Mappin did not succeed, within a certain time, in forming the company and obtaining for Skoines the further money and the shares, Skoines was to be released from his obligation, and he would retain the $£ 1,000$ and the patent." Subsequently, Mappin promoted and became a director of a company which purchased the patent, and the agreement between Skoines and himself was executed.

James, L. J., Bramwell, B., and Brett, J., were of opinion that Mappin was not a promoter when the agreement was made, and that the company was not entitled to the benefit of it. James, L. J., said : -

"At the time when this agreement was made, there was no company in existence, and no promoter, trustee, or

11 Ch. D. 182. 
director ; the company had not even an inchoate existence except in the brain of Mappin; and the utmost that could be said of Mappin was that he was a projector of a company which he intended and had agreed to promote. Having acquired this equitable right in or to the patent - this dominion over it for his own purpose and benefit - having bought what he did buy of Skoines for the lowest price he could get the latter to accept, with the view to sell it at the highest price which he could get, he did what, it appears to me, he lawfully and rightfully might do - he advertised his wares to the public in the following manner. In substance, he says : ' I have an article to dispose of; I am willing to allow persons to become partners and shareholders with me on the following terms and conditions.' He had a right to prescribe his own terms and conditions like any other vendor with any other purchaser. The way in which he made his offer was in the usual way, viz.: he entered into a provisional contract with a person on behalf of the intended company. The making of that provisional contract was, in my opinion, the first period of time at which it could be said that the company had even an inchoate existence, and it was from and after the making of that contract that any fiduciary or other relation between Mappin and the company began. In the making of that contract, in presenting his own terms and conditions, he was, according to my judgment, in the position of any ordinary vendor with any ordinary purchaser. Everything anterior to that was a matter relating to himself and to his own title as vendor. It is surely open to any man, in point of law, to sell his property to a joint-stock company, and to invite persons to form themselves into a joint-stock company to purchase from him, just as it is open to any man to sell to any persons in the world the right to become his partners in any property or undertaking. Until the formation of the part- 
nership he is simply a vendor of the wares; he may ask what price he likes, and obtain what price he can, and he is under no obligation whatever to say what price he gave, or has to give, for them in order to complete his title to the goods. I I really am at a loss to understand on what principles it can be said that Mappin's contract with Skoines was a contract by the company or by any promoter, trustee, or director of the company. It is conceded that if he had bought the patent and paid down the price in money, or contracted to pay down the price in money, he would have been under no obligation to disclose his previous bargains or contracts, though he would have been obliged to show a good title to and to make a good conveyance of the thing which he proposed to sell. And I cannot draw any distinction between a legal right and an equitable right - between a conditional right and an absolute right - between a defeasible right and an indefeasible riglit; all that was still matters of title, and his obligation in any case would have been the same to make a valid conveyance at the proper time of the thing which he undertook to convey. It is said, however, that when the bargain with Skoines is looked at, it contains stipulations about the forming of the com-

1 This was subsequently qualified by Lord Justice James in New Sombrero Co. v. Erlanger, 5 Ch. D. 118, by the explanation that if he deals with a company as a promoter he must act fairly :-

"In this case the Vice-Chancellor appears to have proceeded to a great extent upon what was supposed to have been said in Gover's Case. Now I adhere entirely to what I said in Gover's Case, that is to say, it is quite open to a man to buy property at any price he likes, with the view or in the hope of selling that property to any company that he can get to buy it, if that is the mode in which he intends to dispose of it. A man may buy at any price and may sell at any price that he can get fairly for it. But that has nothing whatever, as it appears to me, to do with the question in this case, which is whether a man who has so bought at a low price has obtained a higher price, fairly and properly, in accordance with the view which the Court of Equity takes of such transactions." 
pany and the constitution of the company and the shares of the company. I cannot myself see that the Court has, for this purpose, any right to read these stipulations. They were stipulations between Mappin and Skoines alone, and obligations as between them. Even if they were stipulations by Mappin to do something wrong in the company or to the company, this might be evidence of that wrong, and proper redress might be given for that wrong as a substantive ground for complaint. But . . . no impropriety in the contract can make it the contract of the company, or the contract of a promoter, trustee, or director of a company, when at the date of the contract there was no company, no promoter, no trustee, no director. The character of the contract cannot operate as a transformation of the contracting parties."

Lord Justice Mellish expressed the following view :

"I agree that if the contract between Skoines and Mappin is to be looked at as an unconditional contract for the sale of the patent from Skoines to Mappin, the company had no interest in the contract, and were not entitled to have its contents disclosed to them. The contract, however, between Skoines and Mappin was a contract, as it appears to me, upon the condition that Mappin should procure the patent to be sold to a company formed for the purpose of working the patent, and if such sale was effected, $£ 64,000$, partly in money and partly in shares, was to be given to Skoines, and the residue of the price, whether money or shares, was to be retained by Mappin. Now, when the company became the purchaser of the patent, that is to say, when the directors, after the formation of the company, adopted the contract made by Mappin and Wright, Mappin was both a promoter and director of the company. The purchase of the patent by the company, who were the only company then in existence formed for 
the working of the patent, enabled him without the knowledge of the company to fulfil his contract with Skoines, and to earn an enormous profit. It seems to me that there are grounds for contending that under these circumstances Mappin ought not to be considered as the owner of the patent, but only as a person who by a contract with the owner of the patent had the disposal of the patent, and in that case, according to the decision of the House of Lords in the Imperial Mercantile Credit Association v. Coleman, ${ }^{1}$ he was bound to communicate his contract with Skoines to the company, and as he did not do so, the company were entitled to the benefit of that contract." 2

1 L. R. 6 H. L. 189.

2 Gover's Case was an application by a shareholder to have her name removed from the list of shareholders in a joint-stock company, on the ground that the prospectus did not contain the date of and the parties to the contract between Skoines and Mappin referred to in the text. The application was based on a provision in the Companies Act that every prospectus of a company shall specify the dates and the names of the parties to any contract entered into by the company, or the promoters, directors, or trustees thereof, before the issue of such prospectus; and that any prospectus not specifying the same shall be deemed fraudulent on the part of the promoters, directors, and officers of the company knowingly issuing the same, as regards any person taking shares in the company on the faith of such prospectus, unless he shall have had notice of such contract. It was held that if the omission to specify the contract in question was within the Act, the relief to which the shareholder was entitled was a personal remedy against those who had issued the prospectus, and not the relief to have her name removed from the list of shareholders. This was sufficient to dispose of the appeal, but two of the four judges also held that the contract in question had not been entered into by a person who was at the date thereof a promoter, director, or trustee of the company, and that consequently it was unnecessary to mention it in the prospectus; from this conclusion the other two judges dissented.

In this aspect of the case, it was material to determine whether or not, under the general law, Mappin was a promoter at the time he entered into the contract in question, and whether or not the company was entitled to the benefit of the contract, as touching the ques- 
$\S 55$. Offer by promoter to corporation entitling it to benefit of his purchase. - It is clear that if one who has acquired an option to purchase property subsequently promotes a company, and, instead of contracting in his own name to sell the property to the company or inviting the company to become shareholders in the property itself, invites them expressly or impliedly to become shareholders with him in the option, or to join with him on terms of equality in purchasing the property from the owner on the best obtainable terms, and they accept that invitation, then by the terms of his offer, and by their acceptance of that offer, he makes himself their agent, as from the date of the option, and any bye or collateral contract made for his own benefit is a contract by a trustee for the company, ${ }^{1}$ and any sum which is secretly taken from the company, in excess of the real cost of the property, belongs to it, and must be returned. ${ }^{2}$

$\S 56$. In Plaquemines Tropical Fruit Co. v. Buck, ${ }^{3}$ - the defendant Buck secured from White an option for the pur-

tion of Mappin's duty under the statute to disclose the contract. The case is, therefore, of value in connection with the point considered in the text.

The view taken by Lord Justice James was quoted with approval in the opinion of Green, V. C., in Plaquemines Tropical Fruit Co. v. Buck, 52 N. J. Eq. 219, while that advanced by Lord Justice Mellish appears to have been adopted by Pitney, V. C., in Woodbury Heights Land C'o. v. Londenslager (N. J. 1896), 35 At. Rep. 436. See Dorris v. French, 4 Hun, 292; South Joplin Land Co. v. Case, 104 Mo. 572.

1 James, L. J., in Gover's Case, 1 Ch. D. at p. 188.

2 It has been suggested that this result should follow in a case where nothing has been paid on the option, and there is no obligation to purchase. There can be no application here, it is said, of the equitable notion that in cases of executory contracts for the purchase and sale of land, the title is, in equity, to be treated as being in the vendee, and the purchase price as a debt due the vendor. Pitkin, V. C., in Wondbury Heights Land Co. v. Londenslager (N. J. 1896), 35 At. Rep. 436.

852 N. J. Eq. 219. 
chase of certain lands at the price of $\$ 25,000$, to be paid $\$ 5,000$ in eash, $\$ 10,000$ in three months, and $\$ 10,000$ in shares of the stock of a corporation to be formed for the development of the lands. Buck then became the sole promoter of the intended corporation; but at no time, either before or after the corporation was formed, did he disclose to it the fact that he had entered into the contract referred to with White. On the contrary, in a prospectus prepared and issued by him, White was spoken of as the grantor in the proposed sale of the lands in question to the corporation. At a meeting of the stockholders, Buck being present, a resolution was passed that the directors purchase the lands from White for $\$ 150,000$, payable, $\$ 120,000$ in shares of stock of the corporation at par, $\$ 10,000$ in cash, and the balance, $\$ 20,000$, by the corporation's notes secured by a mortgage on the lands. Certificates in blank for 12,000 shares were then delivered to Buck to effect the purchase. But White refused to carry out his contract with Buck, who thereupon brought suit for specific performance. This led to an agreement by which White was to convey four thousand acres more than was originally stipulated, reserving the right for one year to cut willows and to clear the land, and was to receive $\$ 27,000$ instead of $\$ 25,000$. This agreement was carried out by a conveyance of the lands from White to Louque, the attorney of Buck, Lonque giving the required note for $\$ 20,000$ and mortgage. Louque then conveyed the lands to the corporation subject to the mortgage. Buck paid White $\$ 5,000$ in cash and transferred to him 700 shares of stock. White then gave up to Buck one of the notes referred to for $\$ 5,000$, and Buck turned it over to a person who had assisted him in his bargaining. The balance of the 12,000 shares Buck retained, distributing part among the other defendants, who were directors and officers of the corporation. On a bill brought by the cor- 
poration against the defendants to compel the surrender for cancellation of the shares of stock thus obtained by them, the foregoing facts having been shown by affidavits, it was ordered that an injunction should issue to restrain the defendants from parting with the stock or voting thereon, until the final hearing of the cause. The Vice-Chancellor, taking the view that " no rights, legal or equitable, arise in favor of a corporation in respect of trausactions, whether complete or inchoate, merely because entered into in contemplation of the creation of such corporation," held that, on the facts shown, Buck must be considered as having made the contract with White, not for himself, but on account of the corporation, and could not be permitted to retain any increase in the price. The fact that part of the consideration to be paid White was, by the terms of the contract, to be paid in stock of the proposed corporation, was considered by the Vice-Chancellor, while not conclusive, as important in determining the question whether the purchase was made for the corporation.

$\S 57$. In Pittsburg Mining Co. v. Spooner, ${ }^{1}$ - the defendants procured an option to purchase certain mining rights for $\$ 20,000$. They then proceeded to obtain subscriptions for the shares of stock of a proposed company which was to be formed to purchase the mining rights. They represented to subscribers that the price demanded by the owners of the mining rights was $\$ 90,000$, and that the property could not be bought for less; that they, the defendants, werc themselves desirous of purchasing, but were unable to pay so much money, and had therefore determined to organize a corporation to make the purchase; that they would bccome subscribers for stock to the extent of their ability; that there was no speculation in the purchase price; that they were making nothing out of it - not even their

174 Wisc. 307. 
expenses, unless the corporation, when formed, should see fit to reimburse them - except what all stockholders would make alike, through the mining operations to be carried on by the corporation; and that $\$ 100,000$ was required in the enterprise, $\$ 90,000$ for the purchase of the mining rights from the owners and $\$ 10,000$ to work the mines.

The defendants then caused a subseription paper to be drawn up, by the terms of which subseribers agreed with the defendant Main, who was described as the owner of the mining rights, to take the number of shares in the Pittsburg Mining Company, "proposed to be formed," set opposite their respective names, and to pay for the same $\$ 2.50$ per share as soon as the company was incorporated. The eapital of the company was to be $\$ 100,000$ divided into 40,000 shares of $\$ 2.50$ each. The entire subseription was written on the terms set forth. The defendants then organized the plaintiff company, being the sole incorporators. Upon the organization, Main subscribed for all the stock, with the exception of two shares subscribed for by the defendants Spooner and Oakley. At the same time, a vote was passed by the defendants, as the sole incorporators and directors, authorizing the issue of the shares subscribed for by Main to him or to such persons as he might designate, upon his transfer of the mining rights to the company. The mining rights were then transferred by the owners to Main, and by Main were transferred to the company. The shares subseribed for by Main were issued to the persons who had agreed with him to take shares, and $\$ 100,000$ was paid by them therefor to the company. The defendants from this sum paid the original owners of the mining rights $\$ 20,000$, kept $\$ 10,000$ in the treasury, and divided the remaining $\$ 70,000$ among themselves. It was held that they must account to the company for the $\$ 70,000$ as secret profit to which the company was entitled. 
$\S 58$. Right of corporation to benefit of optional purchase made by third persons confederating with promoter. - The promoters may, instead of acquiring in their own name an option for the purchase of property to be sold to the corporation at an advance, induce others to acquire the option, in pursuance of a scheme by which the property is to be sold at an advance to the corporation, the interest of the promoters being concealed, and the profits thereby secured secretly divided among the promoters and such third persons as their confederates. In this case they are all alike liable to account to the corporation. The persons confederating with the promoters, although not taking part or assisting in the formation of the corporation or in obtaining its capital, and therefore not promoters or in a fiduciary position towards the corporation, are nevertheless accountable to it on the principle of law that when several persons combine in a fraudulent conspiracy to cheat another, and each takes some part in carrying it out, they are all liable to the defrauded party for the wrong done, and each is liable without reference to the degree of his activity or to the amount of profit which he has reaped from the fraud.

$\S 59$. In Fountain Spring Park Co. v. Roberts, ${ }^{1}$ - the plaintiff corporation sought to recover certain secret profits obtained by the defendants on a sale of land to the corporation. The complaint alleged in substance the following facts: The defendants, Carrick and Willis, were promoters of the corporation which they brought into existence in order that it might purchase a certain tract of land, and that they might secure a secret profit in this purchase when made. One Webber held an option for the purchase of the land in question from the owner at the price of $\$ 12,750$. The defendants, Russell and Roberts, agreed to assist Carrick

192 Wisc. 345. See also Boston $\nabla$. Simmons, 150 Mass. 461; Emery จ. Parrott, 107 Mass. 95. 
and Willis in carrying out their frandulent scheme to secure a secret profit at the expense of the corporation, and it was agreed that the profit should be divided among the four. Carrick and Willis then proeured the formation of the corporation and the subscription of its capital, representing to the subseribers that the land would cost $\$ 23,000$. While subscriptions were being obtained, Russell and Roberts purchased Webber's option for $\$ 600$, and held it subject to the order of Carrick and Willis. Shortly afterward, the land was conveyed to the corporation for $\$ 23,000$, and the profit on the real purchase price of $\$ 12,750$ was secretly divided among the defendants. It was held that the facts stated were, if proved, sufficient to sustain the complaint against all the defendants, and a demurrer, which they had interposed, was overruled.

$\$ 60$. Right of corporation to recover profit obtained by promoter on sale of his property to it.-Definition of term "profit." - When the promoter of a corporation, without disclosing his interest, sells to it property which he purchased, absoIntely or conditionally, before he became a promoter, ordinarily the corporation cannot, as we have seen, claim the benefit of the purchase, and recover the difference between the price paid by it and the price paid by the promoter. But whether or not the corporation may recorer the profit made by the promoter on the sale to it, is another question. This profit is not the difference between the price that the promoter gave and that which he got from the corporation, the promoter may have got the property as a gift, - but the difference between the value of the property at the time of its purchase by the corporation, and the price which the corporation paid. The question may arise in two cases.

$\S 61$. When property is commodity in market. - First. When the property sold to the corporation is a commodity bought and sold in the market, and having a current market 
price. Reasoning from analogy, we may take the rule applicable to one who accepts an agency to buy some article in the market, and then sells to his principal his own goods, without disclosing his interest. In such case the agent is liable to account to the principal for his profit.

Thus, in Parker v. Nickerson, ${ }^{1}$ a bill was brought by the receiver of the East Boston Ferry Company against the defendant for an accounting. The defendant was the treasurer of the company, and had sold a quantity of coal to it for $\$ 9.25$ per ton. He did not originally buy the coal for the purpose of selling it to the company, and did not buy it at a time when it was his duty to buy coal for the company. The coal had been used, so that it was not possible to restore it. The Court held that the amount due to the company was not the difference between the price charged the company and the price at which the defendant purchased, on the plaintiff's theory that the company was entitled to the benefit of the defendant's purchase, but the difference between the price charged and the fair market price at the time of the sale. The authority and duty of the defendant as treasurer of the company, it was held, was to buy coal for it in the market at the market price. He was therefore not entitled to the larger price which he had charged. ${ }^{2}$

By analogy to this rule, is a promoter who sells his own goods to the corporation while occupying a fiduciary position toward it, liable to account to the corporation for his profit? Take, for illustration, a case where a promoter of a railroad corporation sells to it steel rails. The promoter, it is true, is not in the position of an agent to buy ; that duty rests with the directors. But the promoter is in a fiduciary relation to the corporation, and one of the conse-

1137 Mass. 487.

2 See also Kimber v. Barker, 8 Ch. 56; In re Cape Breton Co., 29 Ch. D. at p. 811 ; Bentinck v. Fenn, 12 App. Cas. 652. 
quences of that is, that he is not as a rule permitted to retain a sccret profit arising out of or received by him in connection with the promotion of the corporation. If when he sells his goods to the corporation, he is not dealing with it at arm's-length, he is in no better position with respect to the right to make a secret profit than is the director. For example, although he is not an agent to buy, he cannot retain a secret commission, paid to him by the vendor of property to the corporation from the purchase money. Being, in the cye of the law, under the same disability in this respect as a director, it would seem that if the director must account for a secret profit realized on a sale of his goods to the corporation, the promoter on a similar sale must, on the same principle, be liable to account for his profit. But to support the analogy between the director and the promoter, facts must appear, it seems reasonable to say, to show that the promoter has by virtue of his position as such some advantage over the corporation in making the sale. If competent and disinterested directors, not nominated by the promoter, and not subject to his influence or control, have fairly passed upon the purchase of the property, there would appear to be no ground for holding the promoter accountable for his profit.

$\S 62$. When property is not commodity in market. - Second. When the property sold to the corporation is a specific property, sui generis, such as a mill, or a patent, or a particular tract of land, for the purchase of which the corporation is brought into existence. Here it would seem that the director who owns the property and sells it to the corporation without disclosing his interest is not bound to sell at the market price, or if there is no market price, at the fair price, and the corporation is not entitled to insist on having the property at the market or fair price. If a director, selling under such conditions to the corporation, 
is not accountable to the corporation for his profit, as profit, a promoter, by analogy, would not be liable. There has been some judicial difference of opinion as to the liability of a director to account for his profit under the circumstances stated, but the decisions, and, it would seem, the weight of argument, are in favor of the theory of nonliability. ${ }^{1}$ In the case In re Cape Breton Co., ${ }^{2}$ the question arose, and it was held by a majority of the Court, Bowen, L. J., dissenting, that a director was not so liable. On appeal, in the House of Lords, the decision went off on another point, and the question, although considered, was not decided. ${ }^{3}$ The view that the director must account for his profit was thus stated, in part, by Bowen, L. J.: "It seems to me, upon every principle of justice and equity, to be clear, that in all cases where a person is directly or constructively an agent or trustee for other persons, all profits made by him on behalf of the business in which he is so employed, without the knowledge of his cestuis que trust, belong in equity to his employers, and not to himself. If there was a clandestine profit he must hand it orer. . . . The eestui que trust who seeks to keep the thing purchased, and nerertheless demands the profit improperly made, does not claim to be recouped part of the price, as price, nor attempt in any way to vary the contract. The fraudulent agent or trustee who made the contract knew from the first, or ouglit to have known, that it was an incident of equity and fair play attaching to such a contract, that an agent or trustee was liable, upon demand, to hand back any profit clandestinely

1 In an action to recover damages for a breach of the duty to disclose interest, the profit might or might not afford a measure of the damage; but this presents another question, which will be discussed later on.

$223 \mathrm{Ch}$. D. 795.

3 Bentinck v. Fenn, 12 App. Cas. 652. 
made by him. Making a vendor return something which he ought not to have, is not altering the contract, it is only insisting upon an incident which equity attaches to it. $A$ contract is not set aside merely because an incident which is attached to it by equity is enforced, and in the same way, it scems to me that it cannot be said that, by affirming a contract, the person who affirms it releases any right which is not inconsistent with the contract itself." 1

129 Ch. D. at p. 808. See Goodin v. Cincinnati \& Whitewater Canal Co., 18 Ohio St. 170, as supporting the view taken by Bowen, L. J.

The Cincinnati and Whitewater Canal Company owned and maintained a certain canal. Two railroad companies desiring to obtain control of the canal, and convert it into a railroad track, bought more than half the stock of the canal company, and with the power thus acquired, reorganized its board of directors, putting in place of the old directory, members who were in the interest of the railroad companies, and at their head, as president, a Mr. Lord who was president of the two railroad companies. Proceedings were then begun against the canal company by one of the railroad companies for the condemnation of the canal for use as a track. By an agreement between the boards of directors of the two companies, parties to the proceedings, a jury was dispensed with, the amount of compensation and damages fixed at $\$ 55,000$, and the canal condemned to the use of the railroad company. The amount named was less than the fair value of the canal. At this time certain mortgages given by the canal company were in suit. The railroad companies bought a controlling interest in these mortgages, and thereupon procured a stay of proceedings and an order placing the sum of $\$ 55,000$ in the hands of Mr. Lord, as receiver in the case, in lieu of the canal property. Mr. Lord then, as president of the condemning railroad company, paid to himself, as receiver, the $\$ 55,000$, thus paying to the canal company the amount of the condemnation money. The canal was converted into a road-bed by the railroad company last mentioned, and then leased to the other railroad company.

The plaintiffs, as stockholders and creditors of the canal company, brought their bill in equity making the three corporations parties defendant. The prayer was, that the pretended sale, or condemnation of the canal property, might be set aside as a fraud upon the minority of the stockholders and creditors, who did not participate therein; and that the railroad companies might be enjoined from using the line and fixtures of the canal for railroad purposes, and that if neither of these remedies could be granted, then that the railroad companies might be 
The opposing view was stated by Fry, L. J., in part as follows: "That in such a case the principal would have a right to rescind, there can be no doubt. The option which the principal had, has, in this case, been exercised by confirming the contract with knowledge of the facts, and the question is whether, after that affirmation, the agent is liable in any sum to his principal. .. . It appears to me that to allow the principal to affirm the contract, and after the affirmation to claim, not only to retain the property, but to get the difference between the price at which it was bought and some other price, is, however you may state it, and however you may turn the proposition about, to enable the principal, against the will of his agent, to enter into a

adjudged to hold the property as trustees, and compelled to account for the full value of the same to the canal company or to its stockholders and creditors.

The Court held that the plaintiffs had, by reason of their laches, lost the right to the remedy of rescission, the railroad company having expended large sums of money in constructing works and ways.

"The question of compensation, however," the Court said, " stands upon a very different basis. The railroad company, having acquired this property, ought to pay for it a fair value, unless by an agreement between the parties, such as a Court of Equity will uphold, a less price has been fixed. . Was $\$ 55,000$, then, a fair value for the property? And, if not, did the parties by a valid agreement fix upon a less sum? These, it seems to us, are the only questions remaining in the case, and we are constrained to answer them in the negative. We think the price was grossly inadequate, and that the agreement cannot be sustained in a Court of Equity."

It was accordingly held, that the railroad company was liable to account to the canal company for the full value of the property taken, less the sum of $\$ 55,000$ already paid.

The decision was put on two grounds.

1. The sale was, in effect, a sale by the railroad company to itself. There was no adverse interest or adversary parties, and the sale was a mere form. Such a transaction on the part of a trustee does not bind the cestui que trust.

2. The property of a corporation is a trust fund in the hands of its directors, for the benefit of its creditors and stockholders. 
now contract with the agent, a thing which is plainly impossible, or else it is an attempt on the part of the principal to confiscate the property of his agent on some ground which, I confess, I do not understand. It is said that, notwithstanding the ratification of the contract, the priucipal may claim some profits from the agent because these profits were made surreptitiously or clandestinely. It appears to me that the answer to that is this, that whatever the profits are, and however they are to be measured, these profits result, not from the original contract, but from the affirmance of the contract by the principal, and that, therefore, the profits which are made by the agent are neither clandestine nor surreptitious. . . Where the principal had no right to claim the property as having been purchased on his behalf at the smaller price, the voluntary ratification of the purchase by the principal is equivalent, for this purpose, to a new sale by the agent to the principal after the relation between them had ceased, and it is only in consequence of the ratification or adoption that any profits remain in the hands of the agent. . . . It is not a case of profits made clandestinely or surreptitiously, because those profits have not arisen from the original transaction alone, but from the adoption of it by the principal." I The rule laid down by the majority of the judges in this case was adopted and applied to promoters in Ladywell Mining Co. v. Brooks. ${ }^{2}$

In a recent case in the Supreme Court of Illinois, ${ }^{3}$ it appeared that a corporation had purchased from one of its

$129 \mathrm{Ch}$. D. at p. 811.

235 Ch. D. 400 . See also Great Luxembourg Co. v. Magnay, 25 Beav. 586 ; and the opinions of Lord Cairns and Lord Hatherly in Erlanger จ. New Sombrero Phosphate Co., 3 App. Cas. 1218.

3 Higgins v. Lansingh, 154 Ill. 301, 378. See also Ely $\nabla$. Hanford, 65 Ill. 267. 
directors lands which such director had bought before he became a director. It was held that the corporation could not recover the profit made by the director on the sale; that there could be no rescission without restoring the land. "It might well be," said the Court, " that he would not have sold to the company for what the land would have brought in the market at the time the company purchased it. He had a right to keep the land until he could get his price for it, and we know of no power in a Court of Equity to compel him to sell the land for its market value." 1

Article II. - Accountability of Promoters for Gifts and Commissions.

§63. Explanation of term "promotion money."

64. Accountability of promoters for promotion money.

65. Hichens $v$. Congreve, 4 Russ. 562 ; 1 Russ. \& Myl. 150, n.

66. Beck $v$. Kantorowicz, 3 Kay \& J. 230.

67. Lydney \& Wigpool Iron Ore Co. v. Bird, 33 Ch. D. 85.

68. Bagnall $v$. Carlton, 6 Ch. D. 371.

69. Emma Silver Mining Co. $v$. Grant, 11 Clı. D. 918.

70. Emma Silver Mining Co. $v$. Lewis, 4 C. P. D. 396.

71. MeEllieney's Appeal, 61 Penn. 188.

72. Chandler $v$. Bacon, 30 Fed. Rep. 538.
§ 73. In re Westmoreland Green \& Blue Slate Co., 2 Ch. (1893) 612.

74. Yale Gas Stove Co. v. Foley, 64 Conn. 105.

75. Right of corporation to recover from vendor promotion money which he has secretly agreed to pay to promoter.

76. Accountability to corporation of persons confederating with promoters.

77. Right of corporation to recover from promoters gifts and commissions not obtained at its expense.

78. In re North Australian Territory Co., 1 Ch. (1892) 322.

I In Densmore Oil Co. v. Densmore, 64 Penn. 43, it was held that the promoters of the plaintiff corporation were not liable to account to it for their profit on a sale to it of property which they had purchased before they became promoters ; but the case is not of weight on the question discussed in the text, inasmuch as it appeared that the 
$\S 63$. Explanation of term "promotion money." - The payment of promotion money is a common expedient adopted to secure compensation to promoters. Promotion money consists of money or shares obtained by a vendor of the corporation, nominally as a portion of the purchase price of the property which he sells to the corporation, but in reality as a sum in excess of the price at which he was satisfied to sell, to be handed over to the promoters. It is obtained by intentionally swelling the price for the purpose of making the corporation itself pay the sum it has been arranged that the promoters shall receive as their reward for the part they are to take in the scheme. ${ }^{1}$

$\S 64$. Accountability of promoters for promotion money. Promoter's are in all cases liable to account to the corporation for promotion money received by them, without the knowledge and consent of the corporation. It will not avail them to say that in promoting the corporation they acted as agents for the vendor, that the money has been paid to them by the vendor for services rendered to him, and that it is but reasonable compensation for such services.

"It was urged," said Cotton, L. J., in Bagnall v. Carlton, "why should not the vendor pay his agent? And there was a sum paid to these gentlemen for services to be rendered to the vendor. I said during the argument, and I repeat it, that a vendor may pay his agent - nobody doubts it; but supposing that agent occupies another position, that of agent or trustee for the purchaser, can he, as agent for the purchaser, looking to his position of trustee or agent

promoters disclosed their ownership; that the price at which they sold was fair and reasonable, and that all the original shareholders representing the entire capital stock acquiesced in the transaction at the time.

1 Arkwright v. Newbold, 17 Ch. D. 301.

$26 \mathrm{Ch}$. D. at p. 408. 
for him, retain that which, if he had not occupied that position, he might have received, and properly received, from the vendor?" And in Pearson's Case, ${ }^{1}$ Sir George Jessel, speaking of a promoter who sought to retain promotion money secretly received by him, said: "Can he be allowed to say in a Court of Equity that he, having received a present of part of the purchase money, and being knowingly in the position of agent and trustee for the purchaser, can retain that present as against the actual purchaser?" It is immaterial that the purchase was advantageous, or that the property was worth the price paid. On the theory of trusteeship, the corporation is entitled to recover the amount paid to the promoter. ${ }^{2}$ The cases stated in the succeeding sections will serve to illustrate the rule as to promotion money.

$\S 65$. Hichens v. Congreve. ${ }^{3}$ - The promoters of the company, with the connivance of the vendor, obtained, in the sale of certain mines to the company, a large secret profit or commission which they divided among themselves, their agents, and the directors of the company. A bill was brought against the recipients of the moneys thus divided, to compel restitution to the company. "Upon the face of the bill," said the Lord Chancellor, "I cannot help considering the transactions stated in it to be fraudulent. Sir William Congreve entered into a negotiation with Flattery for the purchase of the property in question at the price of $£ 10,000$, for a joint-stock company of which he was to be a member and a director. After the treaty was begun, the two Clarkes associated themselves with Sir William Congreve in the scheme; and the negotiations with Flattery

15 Ch. D. 336.

2 Pearson's Case, 5 Ch. D. 336 ; Phosphate Sewage Co. v. Hartmont, 5 Ch. D. 394.

84 Russ. 562; 1 Russ. \& Myl. 150, n. 
went on. The object was the purchase of the Arigna mines, in order that they might be conveyed to a company by whom they were to be worked; and the company was to consist, not of Congreve and the Clarkes alone, but of a considerable body of shareholders. It appears that, in the course of the negotiations, Congreve and the Clarkes became desirous of making a profit out of the original transaction for the purchase of Flattery's interest in the mines. The first plan which occurred to them was that a conveyance for the sum of $£ 10,000$ should be made to persons nominated by them, who were afterward to convey to the company for $£ 25,000$. If such a transaction had taken place, and the particulars had been concealed from the company, it could not have been sustained; for, considering the situation in which Congreve and the Clarkes stood with reference to the company, it would have been incumbent upon them to have communicated the real price at which the mine had been purchased of Flattery. This objection appears to have occurred to them; and, accordingly, another shape was given to the proceedings. The plan now adopted was this that a conveyance should be executed directly from Flattery to trustees for the company, and although Flattery had agreed to convey the property for $£ 10,000$, that in this conreyance it should be stated that the purchase money was $£ 25,000$, in order that the difference might be put into the pockets of Sir William Congreve and the two Clarkes, and some other individuals whom they might choose to nominate. Such a transaction is so incorrect, that it is quite impossible that any Court of justice could permit it to stand; and if, after the conveyance had been made, reciting that the price paid to Flattery was $£ 25,000$, a company of shareholders was formed, who acted upon that representation, they could in justice be chargeable only with the money actually paid to Flattery; and if a larger 
sum was taken out of their funds, they would be entitled to call on the individuals into whose hands it came to refund it. In substance, therefore, the plaintiffs are entitled to relief."

$\S 66$. In Beck v. Kantorowicz, ${ }^{1}$ - four out of five persons who entered into a provisional contract to purchase a mine, which they agreed to sell for theil joint benefit to a company to be formed, were deceived by the fifth, the defendant, who, assuring them that the vendors would not take less than $£ 85,000$, obtained secretly from the latter an agreement that, if the contract were perfected and money paid, he should receive thereout a bonus of $£ 20,000$ for his pains in effecting the sale. Two of the four, having absolute powers from the rest to sell to the intended company, then formed themselves with others into a committee of management, and, still ignorant of the surreptitious agreement between the defendant and the vendors, issued a prospectus stating that a contract had been entered into for the purchase by the company of the entire property for $£ 125,000$, "including all preliminary expenses and a premium to the parties who incurred the risk and responsibility of the original purchase." After the company had been established, the required capital paid in, and the provisional contract perfected, the agreement for the payment of the bonus of $£ 20,000$ to the defendant was discovered, and a bill was brought against him to compel an accounting for it to the company. It was held that the transaction in relation to the bonus was fraudulent and void, not only as against the defendant's co-promoters who were associated with him in the original purchase, but also as against the company. It was not enough that the company got the whole of its bargain; it had the right, it

13 Kay \& J. 230. 
was held, to the best bargain which the two members of the committee of management, had they known the facts, would bave been in a position, acting fairly and rightly, to give it. The premium alluded to in the prospectus was a premium of $£ 30,000$ to be paid from the difference between the $£ 85,000$ and the 2125,000 . Another premium, payable out of the $£ 85,000$ to one of the promoters alone, in addition to his share of the $£ 30,000$, was never contemplated in drawing up the prospectus. The defendant, having concealed the arrangement by which he was to receive an extra premium of $£ 20,000$, left it to his co-promoters to fix the amount to be allowed by the company as a premium, and permitted them to contract with the company that the premium should be $£ 30,000$, and no more; and he was decmed thereby to have joined with his co-promoters in making such contract, which it was held ought to be enforced in favor of the company. The defendant was accordingly compelled to account to the company for his bonus of $£ 20,000$.

§ 67. Lydney \& Wigpool Iron Ore Co. v. Bird. ${ }^{1}-$ The facts and the law are thus stated in the opinion of Lindley, L. J. : -

"James Bird procured the company to be formed and to be managed in such way as to transfer from the moneys of the company to himself the sum of $£ 10,800$, without informing the company of that fact. The company were told that they had to pay $£ 100,000$ for the property; but they did not know that of that sum $£ 10,800$ was to go into the pockets of the man who got the company up, and who had in fact increased the purchase price in order to get that $£ 10,800$. . . . That Bird was acting for the vendors does not free him from liability to account for the $£ 10,800$. In procuring that money he was not 
acting in their interest, but in his own, for though in form it was part of the price paid to them, the $£ 10,800$ was in truth to be paid out of the price to him. His liability to account for this rests on his own conduct, not on theirs, and as an agent is personally responsible for his own torts and frauds, though committed by him for other people, so a person acting as Mr. James Bird did in getting $£ 10,800$ from the company, without disclosing the fact, is personally liable to account for it, although in getting up the company he may have been acting for the vendors."

$\S 68$. Bagnall v. Carlton. ${ }^{1}$ - The owners of property employed certain persons as their agents to form a corporation and procure subscriptions for shares to pay for the property, which they agreed to transfer to the corporation for $£ 290,370$. From the proceeds of the sale, the owners agreed to pay the agents $£ 85,000$. The corporation was formed, its capital stock was taken by subscribers, the property was transferred to it, and the purchase price was paid to the vendors, who, in accordance with their agreement, paid therefrom to their agents for their services the sum of $£ 85,000$. The prospectus which was sent out referred to the agreement for the purchase of the property, but made no mention of the agreement between the vendors and their agents in relation to the payment which the latter were to receive. Upon discovering the facts, the corporation brought and maintained an action against the agents to recover their secret profits. The employment of the agents, as the Vice-Chancellor observed, was for the purpose of forming a corporation, and of inducing other persons to subscribe, in reliance upon a representation which was untrue; for it was not true that the purchase money payable to the

$$
16 \text { Ch. D. } 371 .
$$


vendors was the sum mentioned in the prospectus, but it was the purchase money stated, minus the amount to be paid by the vendors to their agents as a reward for procuring the subscriptions, and the nominal purchase money, so diminished, was the true sum which was to go into the pocket of the vendors. The agents were in a fiduciary relation to the company; they combined to induce the belief that the company was purchasing from the vendors at the price referred to in the prospectus which they sent out, when, in fact, by reason of the sum which they secretly received, the price was less; and they were accordingly holden to account for the secret profit, on the ground that the corporation was entitled to the benefit of the real price, as negotiated by the defendants in their fiduciary capacity, which bound them to bargain for the corporation and not for themselves.

§ 69. Emma Silver Mining Co. v. Grant. ${ }^{1}-$ The Emma Mine was an American corporation in which Park and Stewart were interested. Acting in its behalf, they went to England to negotiate a sale of its mine, and to promote a corporation to purchase it. They entered into an agreement with Albert Grant to sell the mine for $£ 1,000,000$ to a corporation to be organized for the purpose of buying it. It was agreed that Grant should be paid by the vendors for his services twenty per cent. of the amount of the capital of the corporation. Park, Stewart, and Grant then organized the corporation as the "Emma Silver Mining Company, Limited," the mine was transferred to it at the stipulated price, and the vendors paid Grant the commission agreed upon, the agreement under which it was paid not having been divulged. As a promoter, Grant was compelled to account to the corporation for his secret profit. He was not the owner of the mine; he was in a 
fiduciary relation to the corporation, and bound to act in its interest in bringing about the purchase of the mine; yet, while in this position, he contracted to obtain a secret commission from the vendors of the mine, and through the prospectus, which was issued by him, made representations calculated to induce the belief that the owners of the mine were selling it to the company for $£ 1,000,000$, when in fact, by reason of the amount to be secretly paid by them to him, the price was much less than that. The corporation was entitled to the benefit of the real price, and accordingly recovered the secret profit as money received by Grant as a trustee for it.

$\S 70$. Emma Silver Mining Co. v. Lewis. ${ }^{1}-$ Defendants entered into a secret agreement with the owners of a mine, by which they were to assist in its sale to a projected corporation, and were to be given therefor by such owners 250 of the paid-up shares of the corporation, which were to be issued in part payment of the purchase price. The defendants allowed themselves to be referred to in a prospectus for information concerning the mine; but although they were acquainted with facts detrimental to the reputation of the mine, they did not disclose them. It was held that the acceptance by the defendants of the reference to them in the company's prospectus imposed upon them a duty to the corporation to answer candidly such inquiries as might be made by intending applicants for shares, and that by this acceptance they undertook the duty of assisting to float the corporation by answering the inquiries of persons proposing to take shares in it, and that therefore they were promoters. Being promoters and in a fiduciary relation to the company at the time they acquired their right to receive from the vendors a profit of 250

14 C. P. D. 396. 
shares, that profit belonged to the corporation, and judgment was rendered in favor of the corporation for the value of such shares, under its claim "for profits received by the defendants for the use of and as trustees for the plaintiff."

$\$ 71$. McElheney's Appeal. ${ }^{1}$ - McElheney, the owner of land, sold it for $\$ 12,000$ to certain persons who proposed to form a corporation to which to dispose of it at an advance. He then associated himself with these persons to form a corporation, with the agreement that he was to share in the secret profit to be derived by them from the sale to the corporation. The corporation was formed and the property transferred to it for $\$ 40,000$, the interest of the promoters being concealed. Of this sum, McElheney received over $\$ 2,000$ as his share of the profit. In the original sale he was not in a fiduciary position, and so that transaction stood; but as to the subsequent sale, lie became a promoter of the corporation, and was not allowed to retain the secret profit. The receipt of this money, by means of the fraud practised in his fiduciary relation, was a wrong to the corporation, and he was compelled to account for the money. At the time of the sale to the corporation he did not own the land, but accepted a secret profit from the vendors of the corporation.

$\S 72$. In Chandler v. Bacon, ${ }^{2}$ - the defendants were promoters and officers of the National Color Printing Company, which was formed with a view to the purchase of certain patents owned by the United States Label, Card, and Tag Company. As such promoters, they entered into an agreement with the latter company for the sale of the patents by it to the former company when organized. Under this agreement they were to receive as a bonus, and did receive from the old 
company, 3,125 shares of the stock of the new company transferred to it in part payment of the purchase price of the patents. This fact they concealed. Subscribers for stock in the new company paid $\$ 7.00$ a share to the company. The defendants, as promoters, obtained their stock without consideration. The case was that of a secret gift to the promoters of the company from the vendors of the patents. By reason of their fiduciary relation towards the new company at the time of the purchase of the patents by it, they could not secretly participate in the profit of the transaction, and were accountable to the company for the profits received by them.

$\S$ 73. In re Westmoreland Green and Blue Slate Co. ${ }^{1}$ Poole and Binns were interested in certain quarries which they were desirous of making over to a company to be formed for the purpose. They employed Ashworth and Bland to assist them in getting up the company. By an agreement of the 16th of February, 1886, Poole, Binns, Ashworth, and Bland entered into an agreement to hand over the quarries, among which was that known as Stone Dykes, to the proposed company in consideration of $£ 2,600$ in cash and $£ 4,000$ in fully paid-up shares, of which Bland and Ashworth were each to receive 120. On the same day a lease of Stone Dykes quarry, a lease of which Poole was entitled to call for, was granted to the four promoters. The company was formed. The agreement was made by the promoters, as vendors, with a trustee for the intended company, the quarries were transferred to it, and Binns and Ashworth received their shares. The company was subsequently wound up. In the course of the winding up, Bland was examined. He admitted that up to the 16 th of February, 1886, he had no interest in Stone Dykes, and

12 Ch. (1893) 612. 
that he had nothing to do with fixing the purchase money. An order was made that Bland should contribute to the assets of the company the par value of the 120 shares received by him. It was contended for Bland that he rendered services to Poole, for which Poole gave him an interest in the property sold, and he was therefore a real vendor. The Court, however, regarded the transaction as "a novel and ingenious attempt to evade the law as to secret profits." If Ashworth and Bland had been bona fide owners of sliares in Stone Dykes, and had been agreeing to sell their interests for shares in the new company, the transaction could not have been impeached. But, as the Court observed, "This was nothing but a sclieme to enablc Bland and Ashworth to get from the company 120 paid-up shares each for their services in getting up the company."

$\S 74$. In Yale Gas Stove Co. v. Foley, ${ }^{1}-$ Foley, the owner of a patent, entered into an agreement with Wilcox, by which the latter was to organize a corporation to purchasc and work it, and Foley was to transfer the patent to it for a certain consideration, one-half of which he was to turn over to Wilcox for his services. Wilcox proceeded to form the corporation, and obtained subscriptions for its stock. He became a director, the purchase of the patent was consummated, and one-half of the purchase price was turned over to him by Foley. He was eompelled to account to the corporation for it. His agreement with Foley was concealed. This agreement contained a provision that upon the organization of the corporation Foley would assign onehalf of his interest in the patent to Wilcox. In view of this, it was contended, on the authority of Ladywell Mining Co. v. Brooks, ${ }^{2}$ that Wilcox had acquired an interest in the patent before he became a promoter of the corporation, and therefore was not accountable for his profit; but it was

164 Conn. 105.

$235 \mathrm{Ch}$. D. 400. 
found, as matter of fact, that the patent was transferred by Foley to the corporation, and that the agreement did not contemplate the acquisition by Wilcox of any title to the patent, but simply the organization of a corporation by him, the sale to it of the patent, and then a division between Foley and himself of the avails of the sale. The case, therefore, was that of a promoter of a corporation who has received a secret commission from a vendor of the corporation.

$\S 75$. Right of corporation to recover from vendor promotion money which he has secretly agreed to pay to promoter. - The corporation may recover from the vendor any promotion money which may be in his hands under a secret agreement that it is to be turned over to a promoter. Thus in Whaley Bridge Calico Printing Co. v. Green, ${ }^{1}$ it appeared that Green had purchased certain calico printing works for $£ 15,000$. Green and Smith associated themselves together as promoters of a company formed for the purchase of the works from Green, and for the purposes of the negotiations for such purchase, a contract, which the jury found to be a sham contract, was entered into between them for the pretended sale of the works by Green to Smith for $£ 20,000$. The company was ultimately formed, its directors being nominees of Green and Smith and the works were conveyed by Green and Smith to the company for $£ 20,000$. It was agreed between Green and Smith that the former should pay the latter $£ 3,000$ out of the purchase money, but this agreement was not communicated to the directors of the company when the sale to the company was effected. It was held that the company was entitled to treat the agreement stated as made by Smith in its behalf, and to enforce it against Green, and that it could recover from Green so much of the $£ 3,000$ which he had agreed to pay to Smith as he had not turned over to him. Mr. Justice Bowen said:

15 Q. B. D. 10 . 
"In many unexecuted contracts the principal could not substitute himself in the agent's place, as the person for whose benefit the contract was to be performed, without altering substantially the character of the contract. But when nothing has to be done under the contract but payment of money to the agent, I think that the principal, under circumstances such as these, is entitled to stand in the agent's shoes and compel a payment of money directly to himself."

The promoter himself cannot in such a case enforce a secret agreement by a vendor to pay him for his services as a promoter. ${ }^{1}$ Such an agreement is not in itself illegal, provided it is not to be kept secret from the company, when the company is induced to negotiate with the vendor; but the element of secrecy makes it corrupt as between the parties to it. ${ }^{2}$

$\S 76$. Accountability to corporation of persons confederating with promoters. - Persons who are not promoters, but who knowingly aid and abet promoters in securing secret commissions, and share in such commissions, become wrongdoers, and the corporation may compel them to pay over to it moneys which they lave thus received. ${ }^{3}$ The corporation may also, it would seem, recover from such persons and the promoters, jointly or severally, damages for the injury caused by the wrong-doing. The abuse of trust of which the promoters are guilty, with the knowledge and cn-operation of such persons, is a wrong for which they are all liable, as the injury to the corporation is the result of their combined action. 4

1 Yale Gas Stove Co. v. Wilcox, 64 Conn. 105; Harrington $\nabla$. The Victoria Graving Dock Co., 3 Q. B. D. 549.

${ }_{2}$ Whaley Bridge Calico Printing Co. v. Green, 5 Q. B. D. 109.

8 Emery v. Parrott, 107 Mass. 95; Fountain Spring Park Co. จ. Roberts, 92 Wisc. 345.

4 Boston v. Simmons, 150 Mass. 461; Mayor, \&c. of Salford v. Lever, 25 Q. B. D. 363; affirmed 1 Q. B. (1891) 168. 
$\S 77$. Right of corporation to recover from promoters gifts and commissions not obtained at its expense. - The rules in relation to secret profits obtained by trustees or agents out of the matter of their trusteeship or agency, having been quite generally extended to promoters, it would seem that secret commissions or profits received by promoters from vendors of property to the corporation, in connection with the promotion of the corporation, or in consideration of services rendered by them in the course of such promotion, ought, speaking generally, to be recoverable by the corporation from the promoters, although the purchase price was not swollen for the purpose of making the corporation pay such commissions or profits. A trustee is not, without the knowledge or consent of his cestui que trust, permitted to make any profit out of the matter of his trusteeship, beyond his proper remuneration as trustee. A commission paid him by persons with whom he is dealing, in behalf of his cestui que trust, may not originally come from the funds of the cestui que trust; but, because the trustee is accountable for it, it does in effect come from and is obtained at the expense of the cestui que trust, who may accordingly claim it. "Commission," said James, L. J.," " received by an agent or trustee of a purchaser from a vendor, without the knowledge of his principal, is, in this Court, a bribe it is the profit which the principal has a right to extract from an agent whenever it comes to his knowledge." It is not permissible for the vendor secretly to have the agent of the purchaser in his pay. The promoter is constructively an agent or trustee for the corporation, and it would seem that ordinarily the same prohibition ought to be made in his case. ${ }^{3}$

1 See remarks of Lindley, L. J., quoted in Sect. 23.

2 Phosphate Sewage Co. v. Hartmont, 5 Ch. D. at p. 457.

${ }^{3}$ But see Bagnall v. Carlton, $6 \mathrm{Ch}$. D. 371, where one of the promoters of a corporation received from a cestui que trust of certain prop- 
$\S 78$. In re North Australian Territory Co. - In a recent case, ${ }^{1}$ the Court passed upon a secret arrangement between a promoter and a director of a corporation by which the latter obtained an advantage, at the expense of the corporation, in the sense mentioned in the preceding section. The facts in the case were these: Archer was requested by the promoter of a projected corporation to become a director. He agreed to do so upon the terms that if he should at any time desire to part with the shares necessary for him to take to qualify him as a director, the promoter should take them off his hands at the price he paid for them. The corporation was subsequently formed, and Archer became a director, taking the qualification shares and paying for them at par out of his own money. His agreement with the promoter was not disclosed. He afterwards resigned his office of director, and, subsequently to his resignation, the promoter, at his request, paid to him the sum which he had paid for the shares, and accepted a transfer of them. At that time the shares were valueless in the market. In the winding up of the corporation, the liquidators asked that Archer be ordered to pay to them the sum received by him from the promoter, with interest. It was held that whatever benefit accrued to him under the indemnity constituted by his secret agreements with the promoter belonged to the corporation, and that the retention by him of the proceeds of the indemnity occasioned a loss to the corporation for which he was accountable, with interest, upon the principle of Hay's Case and Pearson's

erty sold to the corporation $£ 1500$ as a commission agreed to be paid to him in case he found a purchaser for the property. It was held that he was not accountable to the corporation for this sum, on the ground that it was not paid out of the purchase money, but by one of the parties beneficially interested in the property, in respect of a personal liability, and out of his own pocket.

1 In re North A ustralian Territory Co., 1 Ch. (1892) 322. 
Case. ${ }^{1}$ The following colloquy between the Court and counsel for Archer, which occurred during the argument, is instructive: Fry, L. J.: "Why should not Archer be accountable for the $£ 500$, as property of the company retained by him?" Counsel : "The real question is, Did the company suffer loss by what was done? They never had the $£ 500$, and therefore cannot be said to have lost it. In the majority of cases in which a director has been held accountable to the company he has, in effect, received money which originally came from the coffers of the company, as in Hay's Case, and the cases already mentioned." Bowen, L. J.: "Smith, being in a fiduciary relation to the company, had no right to give a director a benefit without the company knowing it. An indemnity against loss is a valuable consideration." Counsel: "At the time the letter was written Archer had not taken the shares, and had not then agreed to become a director." Fry, L. J.: "Would an honorable man assent, as Archer did, to accepting this indemnity, on the terms that he was to keep it secret? If it was not actually dishonest, it seems to me to be a very improper course of proceeding." Bowen, L. J.: "Is it right that the wolf should give a sop to the watch-dog, without his master's leave?" 2

\section{Supra, Sect. 64.}

2 The case of a solicitor who is a trustee under a will or deed which contains no power to charge for professional services, furnishes an example of the severity of the rule applied to trustees. Such a solicitor trustee is not entitled to fees for legal services rendered by him in the administration of the trust. In Broughton v. Broughton, $5 \mathrm{De}$ G. M. \& G. 160, in which this question was presented, Lord Cranworth said: "The rule applicable to the subject has been treated at the bar as if it were sufficiently enunciated by saying that a trustee shall not be able to make a profit ont of his trust; but that is not stating it so widely as it ought to be stated. The rule really is that no one who has a duty to perform shall place himself in a situation to have his interests conflicting with that duty. . . No person 
in whom fiduciary duties are vested shall make a profit of them by employing himself, because in doing this he cannot perform one part of his trust, namely, that of seeing that no improper charges are made." See Sherman v. White (Illinois), 28 Chicago Legal News, 199, holding that a trustee cannot be allowed to retain commissions, received by him as a member of a board of underwriters, for placing insurance on the trust estate, although it appears that he could not have obtained insurance at any less rate. In a recent valuable little work on trustees, the author, speaking of the rule referred to, says: "It has been applied by the Courts of Equity fearlessly - not only to trustees of the kind we are now speaking of, but to all persons who stand in a fiduciary relationship to others. Nor is the present time one when either Parliament or judges are likely to relax the pressure of the rule in any single respect. The habit of secret commissions given and taken every day (so at least it is confidently asserted) by persons in good positions, who account themselves, and are accounted, honest men, is one to be scorned by Courts of law. It is the plain duty of legislators and judges to hand down from one generation to another (so far as they can) untarnished, and of full authority, those principles of absolute integrity to those who employ you, or on whose behalf you profess to act, which are not only compatible with prosperity, but are essential to commercial greatness and well established success." Bissell on the Duties and Liabilities of Trustees, 66. 


\section{CHAPTER IV.}

MEASURE OF PROFITS RECOVERABLE BY CORPORATION. STATUTE OF LIMITATIONS AS A BAR TO SUIT FOR THEIR RECOVERY. - SURVIVAL OF CAUSE OF ACTION.

$\S 79$. View that net profit only recoverable.

80. Moditication of this view.No allowance for expenditures ultra vires the corporation.

81. English decisions based on provisions of the Companies Acts.

82. Interest recoverable.

83. Rule when gift, commission, or profit is in form of shares of corporation's stock.

84. Statute of Limitations as a bar to suit to recover profits.
$\S 85$. Metropolitan Bank v. Heiron, 5 Ex. D. 319.

86. Statute runs from time of disclosure to or knowledge by corporation.

87. In re Fitzroy Bessemer Steel Co. v. Smith, 50 L. T. Rep. N. 8.144.

88. Right of action not divested short of period of statute without accord and satisfaction or release under seal.

89. Right of action survives against personal representatives of promoters.

$\$ 79$. View that net profit only recoverable. - When a promoter is called upon to account to the corporation for promotion money, or, in case he is a vendor of the corporation, for the profit made by him in the sale, he cannot, according to the English decisions, claim as of right any commission or payment for his services in promoting the corporation, but may retain the amount of his proper disbursements for costs and. expenses in such promotion. In Emma Silver Mining Co. v. Grant, ${ }^{1}$ it was said by Sir George Jessel, Master of the Rolls, that the broad view of the case is to take the whole transaction, and see how much more money the promoter has got than he would have had, if he had never entered into it at all. Adopting this view, the Master of the Rolls held that, if a promoter has expended money in good faith to promote the corporation,

111 Ch. D. at p. 938. 
the Court will not inquire into the propriety or morality of his expenditures; and he allowed Grant for money paid by him to persons who procured directors for the corporation, for shares furnished to qualify the directors, for money paid to brokers to sustain the price of the shares in the market, to persons connected with the press for puffing or laudatory statements respecting the corporation and its mine, and to certain brokers as a consideration for their wairer of an option to purchase shares. ${ }^{1}$

$\S 80$. Modification of this view. - No allowance for expenditures ultra vires the corporation. - The view thus laid down has not, howerer, been accepted without qualification. It has been modified to this extent, that the expenditures to be allowed must be such as do not involve a misapplication of the corporation's funds, or amount to acts ultra vires the corporation. $^{2}$ In Lydney \& Wigpool Iron Ore Co. v. Bird, ${ }^{3}$ the Court of Appeal, while allowing the defendant Bird for expenses incurred by him in the promotion of the company, such as advertisements, printing, solicitors' and brokers' charges, refused to allow him the sum of $£ 5,000$ which he had paid for a guarantee of the subscription of the capital of the company. In a later case, ${ }^{4}$ the same Court held that it was not ultra vires the corporation, nor an improper expenditure of its funds, to pay brokers a reasonable and usual commission for placing the corporation's shares. The case was distinguished from Lydney \& Wigpool Iron Ore Co. v. Bird, Lindley, L. J., saying of that case: "The money there sought to be recovered was not money which was paid

1 See also Bagnall v. Carlton, 6 Ch. D. 371.

${ }^{2}$ In re Faure Electric Accumulator Co., 40 Ch. D. 141 ; Capel v. Sims Ships Compositions Co., 57 L. J. Ch. 713; Lydney \& Wigpool Iron Ore Co. v. Bird, 33 Ch. D. 85.

33 Ch. D. 85.

4 Metropolitan Coal Consumers' Association v. Scrimgeour, 2 Q. B. (1895) 604 . 
by the company for placing shares. There was a person named James Bird, who was a promoter of the company, and he secretly made a profit, at the expense of the company, of $£ 10,800$. He was made liable for it. He said, - Well, I have spent $£ 5,000$ as a consideration, which I gare to William Bird for guaranteeing me that shares should be taken up in this company, and we disallowed James Bird that bill. The whole thing was a juggle from beginning to end ; and we disallowed it on the ground that it was an improper transaction, - and so it was. It has nothing whatever to do with, and is far away and remote from, such a case as this where there is no juggle and no impropriety at all."

\section{$\S 81$. English decisions based on provisions of the Companies} Acts. - In reading the English cases on this subject, it should perhaps be noted that under the English Companies Act, ${ }^{1}$ the directors of a company may pay all expenses incurred in getting up and registering the company. Yet, while the Act confers the power, it does not impose an obligation to pay such expenses when incurred by promoters; and it would seem that, in the absence of legislation of the nature stated, payment from the funds of the corporation of the fair and reasonable expenses incident to its formation is not improper or beyond the powers of the corporation. Assuming this to be so, it would appear to be equitable, in an accounting between the promoter and the corporation, to allow the promoter all legitimate expenses incurred by him in the work of organization and securing the capital. ${ }^{2}$

1 Table A. paragraph 55.

2 In Sherman v. White (Illinois), 28 Chicago Legal News, 199, a trustee who had, as a member of a board of underwriters, received commissions for placing insurance on the trust estate, was compelled to account for them, but was allowed in the accounting six hundred dollars paid by hin for membership dues in the underwriters' association during the period in which he received the commissions. 
\$ 82. Interest recoverable. - When one has in his hands money of another, which he has obtained by fraud, or wrongfully retains money which he ought to pay over to another, interest may be recorered thereon, by way of damages, for the breach of an implied promise to pay it over. Promoters who are accountable to the corporation for profits or commissions are accordingly chargeable with interest on that which is withheld by them from the time it is withlield. ${ }^{1}$

$\S 83$.- Rule when gift, commission, or profit is in form of shares of corporation's stock. - When the profit or commission is in the form of shares of the capital stock of the corporation, the corporation may, at its option, pursue one of three courses. It may compel the promoter, if he has not parted with the shares, to transfer them to it, and to account for any dividends he may have received thereon. ${ }^{2}$ Although he has not transferred the shares, or sold them at a profit, the corporation may compel him to pay the highest market value attained by the shares between the time of their delivery to him and the time when knowledge of the fact of such delivery came to the corporation, with interest. The right to such recovery rests upon the theory that the corporation has been deprived of the right of placing the shares with other persons, and that for the loss occasioned thereby the promoter is accountable. ${ }^{3}$

1 Mason v. Waite, 17 Mass. 560 ; Manufacturers' National Bank v. Perry, 144 Mass. 313; Greenly v. Hopkins, 10 Wend. 96.

2 Chandler v. Bacon, 30 Fed. Rep. 538.

${ }^{3}$ McKay's Case, 2 Ch. D. 1 ; Pearson's Case, 5 Ch. D. 336 ; De Ruvigne's Case, 5 Ch. D. 306 ; In re Fitzroy Bessemer Steel Co., 50 L. T. Rep. N. s. 144 ; Eden v. Ridsdale's Ry. Lamp \& Lighting Co., 23 Q. B. D. 371 ; Huntington \& Broad Top. Ry. \& Coal Co. v. English, 86 Penn. 247; North v. Phillips, 89 Penn. 250; Galigher v. Jones, 129 U. S. 193 ; Wright v. Bank of the Metropolis, 110 N. Y. 237. The rule of highest intermediate value has been in many jurisdictions adopted in 
Thus, in Chandler v. Bacon, ${ }^{1}$ the promoters of a corporation received as a secret gift from the vendor of the corporation certain of the shares issued to such vendor in payment for a patent transferred by him to the corporation. It appeared in evidence that a large amount of the stock of the company had been taken by the public at a uniform price of $\$ 7.00$ per share. It was held that the promoters must account to the corporation for their stock at this price. In Nant-y-Glo \& Blaina Iron Works Co. v. Grave, ${ }^{2}$ a promoter improperly obtained shares of the corporation in 1871, and held them when suit was brought against him by the corporation in 1877 . They were then worth $£ 1$ per share. The lighest market price which they had attained in the interval was $£ 80$. It was lield that the promoter must account for the shares at the price of $£ 80$, with interest from the time that he received them. If the promoter has sold the shares, the corporation may require him to pay the amount he has realized therefrom, and the amount of dividends he has received with interest. ${ }^{3}$

When the promoters have combined or confederated in a scheme to secure secret profits improperly at the expense of the corporation, they may be held jointly liable in a suit by the corporation to recover such profits. ${ }^{4}$

$\S 84$. Statute of limitations as a bar to suit to recover profits. - It is true that no time will bar a suit by a cestui

the ordinary action for conversion of shares of stock. In some States it has been repudiated. The objection urged is that ordinarily it is mere conjecture that the owner would have obtained the bighest intermediate value; the presumption that the owner would have disposed of his shares when they reached the highest price, would rarely, it is said, accord with fact. The subject is well treated, and the cases are collected and classified in Hale on Damages, 186, et seq.

130 Fed. Rep. 538.

212 Ch. D. 738.

3 In re Fitzroy Bessemer Steel Co., 50 L. T. Rep. N. s. 144.

1 Chandler v. Bacon, 30 Fed. Rep. 538. 
que trust against his trustee when the trustee has a fund in his possession and wrongfully wastes it. Express trusts are not within the Statute of Limitations, because the possession of the trustee is presumed to be the possession of the cestui que trust until the trustee duly discharges himself. ${ }^{1}$ But the statute is available as a bar in cases of constructive trusts, as where one has receired money in his own right, and is afterwards by construction held to have receired it as a trustee for another whose right to it is thus established. ${ }^{2}$ Money or property improperly obtained by a promoter as a profit, gift, or commission, is not the money ol property of the corporation unless it is made so by a decree founded on the act by which the promoter obtained the money or property. The case of the promoter is therefore that of a constructive trust. His liability is a debt differing from ordinary debts only in the fact that it is equitable; and in dealing with equitable debts of such a nature, Courts of Equity follow by analogy the provisions of the Statute of Limitations. ${ }^{3}$

$\S$ 85. In Metropolitan Bank v. Heiron, ${ }^{4}$ - an action was brought by a company in 1879 against a former director to recover $£ 250$, on the ground that the defendant had received that sum from a debtor to the company as a bribe to induce him to use his influence to obtain favorable terms of compromise for the debtor. The allegation that the bribe had been given, had, in 1872 , been brought before the directors at a board meeting; they had investigated it and came to the conclusion that the charge was unfounded; and it did not appear that they had acted in the matter

1 Speidel v. Henrici, 120 U. S. 377 ; Hovenden v. Lord Anniesley, 2 Sch. \& Lef. Ch. 621.

2 Price v. Mulford, 107 N. Y. 303 ; Baxter v. Moses, 77 Me. 46๊̃ ; Ashurst's Appeal, 60 Penn. 290.

${ }^{8}$ Metropolitan Bank v. Heiron, 5 Ex. D. 319.

45 Ex. D. 319. 
otherwise than in good faith. It was held that the action was barred by the Statute of Limitations. ${ }^{1}$

$\S 86$. When statute begins to run.-The statute runs from the time the facts are made known to or discovered by the corporation. In cases of fraud the statute ordinarily runs from the time of the commission of the fraud, unless there lias been some affirmative act of concealment; but when a fiduciary relation exists between the parties, it is the duty of the party complained of to make disclosure, and silence amounts to concealment. ${ }^{2}$ It is the duty of a promoter who has wrongfully received a profit, gift, or commission to disclose the fact. His omission to do so will prevent the Statute of Limitations from running in his favor against the corporation, until the facts are discovered by it. The facts must be made known to the directors, or, if they are implicated, to the shareholders.

$\$ 87$. In In re Fitzroy Bessemer Steel Co. v. Smith, ${ }^{3}-a$ promoter of the company made an agreement with the syndicate of vendors, by which he was to receive $1,000 \mathrm{~B}$ shares in the company, in consideration of his taking or placing $500 \mathrm{~A}$ shares. The agreement was subsequently carried out. Notice of this transaction was, after the formation of the company, given to the directors; but the board which received the notice consisted of persons more or less implicated in the transaction, and no action was taken in the matter. The company was afterwards wound up, and the liquidators sought to recover from Sinith the value of the $1,000 \mathrm{~B}$ shares, on the ground that his having received them under the circumstances was a misfeasance against the company. It was contended that the claim was barred

1 See also De Bussche v. Alt, 8 Ch. D. 286.

2 Atlantic Bank v. Harris, 118 Mass. 147 ; Wickersham v. Lee, 83 Penn. 416.

850 L. T. Rep. N. s. 144. 
by the Statute of Limitations, the company having through its directors receired notice of the transaction more than six years previously. It was held that, though notice to the directors is prima facie notice to the company, yet it was not notice in this case, it being certain that the directors would not communicate the information to the stockholders, and that accordingly the claim was not barred by the statute.

$\S 88$. What will divest right of action within period of statute. - While the Statute of Limitations may be a bar to a suit by the corporation to recover secret profits, when the corporation is entitled to claim such profits, the right of action rested in it, cannot, for a period short of the statute, be divested without accord and satisfaction or a release under seal. An express promise not to sue could not in itself constitute a bar to proceedings, for the promise would be without consideration and therefore not binding. But there might be estoppel by conduct. ${ }^{1}$

$\S 89$. Right of action survives against personal representatives of promoters. - A claim for secret profits against a promoter, bcing founded on breach of a fiduciary duty, will survive against the personal representatives of the promoter. ${ }^{2}$ And this holds good as against a promoter who has not himself participated in such profits, but has been a party to the scheme by which they were obtained, and were appropriated by his co-promoters. The principle on which this rests is illustrated in Walsham v. Stainton. ${ }^{3}$ Here A. and B., who were in a fiduciary relation to a

1 De Bussche v. Alt, 8 Ch. 1). 286.

${ }^{2}$ New Sombrero Phosphate Co. v. Erlanger, 5 Ch. D. 73 ; Ramskill v. Edwards, 31 Ch. D. 109 ; Phillips v. Homfray, 24 Ch. D. 439, 11 App. Cas. 466 ; Batthyany v. Walford, 36 Ch. D. 269 ; Concha v. Murietta, 40 Ch. D. 543 ; Warren v. Para Rubber Shoe Co., 166 Mass. 97.

${ }^{3} 1$ De G. J. \& S. 678. 
partnership, combined together fraudulently to obtain the shares of the partners at an undervaluation. A. was a party to the fraud, but the whole benefit of it accrued to B. It was held that A.'s estate was liable, though not benefited. ${ }^{1}$

1 An action for damages for false and fraudulent representations (e. g., in a prospectus issued by the directors of a corporation inviting subscriptions for shares) will not, in the absence of a fiduciary relation, survive against the personal representatives of the person committing the fraud, unless they have received an estate benefited by the fraud. Hambly v. Trotl, 1 Cowp. 371 ; Peek v. Gurney, L. R. 6 H. L. 377, 392-395; Houghton v. Butler, 166 Mass. 547. See the valuable English and American Notes in 2 English Ruling Cases, at p. 14. The right of action of a person who has been deceived by fraudulent misrepresentations survives, if an injury has accrued to his personal estate. Twycross v. Granl, 4 C. P. D. 40 ; 48 L. J. (Q. B.) 1 ; Hatchard v. Mège, 18 Q. B. D. 771. In most of the States there is legislation as to the survival of actions, which affects the common-law rule. 


\section{CHAPTER V.}

BREACH OF DUTY OR FRAUD BY PROMOTERS AS GROUND FOR RECOVERY OF DAMAGES FRON THEM BY CORPORATION, AND FOR PROCURING THE SETTING ASIDE OF EXECUTED CONTRACTS ENTERED INTO BY IT.

Anticle I. - Liability of Promoters in Damages to the Corporation.

Article II. - Rescission by Corporation of Contracts entered into by it with or through Promoters.

Article I. - Liabilities of Promoters in Damages to the Corporation.

$\S 90$. Rule laid down in Taylor on $\mid \S 92$. Instances where promoters Corporations.

91. Damages recoverable for breach of duty damnifying corporation.

$\S 90$. Rule laid down in Taylor on Corporations. - The author of a work of authority on corporations, ${ }^{1}$ observing that " the relationship existing between the promoters and the corporation as subsequently organized is a fiduciary relationship regulated by legal and equitable principles in many respects similar to those applicable to the relationship of agency," adds, "but not in every respect, for the corporation, in the nature of things, not having entrusted its property to the promoter, never having employed the promoter to act for it, and not being bound by his contracts unless it ratifies or voluntarily accepts the benefit of them after its incorporation, could ordinarily bring no such action against a promoter for misfeasance

I Taylor on Corporations, 2d ed., Sect. 82, n. 1 . 
as a corporation could bring against one of its officers. A promoter, to be sure, would be liable to the corporation in damages for any fraud committed by him, in contracting with it, of a nature that would render one individual liable under ordinary circumstances to another. But usually the only action maintainable by a corporation against its promoters is an action to make them disgorge secret profits."

$\S 91$. Damages recoverable for breach of duty damnifying corporation. - It would seem, however, that misfeasance by a promoter, when in the nature of a breach of duty and an act resulting in pecuniary loss to the corporation, will ground an action by the corporation for damages. When a trustee commits a breach of duty, as, for example, by accepting a secret bribe, he cannot acquit himself of all obligation by giving up that which he has received. He must pay the damages occasioned by his wrongful conduct. ${ }^{1}$ Special duties similar to some of those imposed upon trustees rest upon promoters. It is a familiar principle that when the law imposes upon one a duty, any person to whom that duty is owing, and who suffers special injury from its breach, may maintain an action to recover his damages. If the promoter of a corporation violates his duty to it to its injury, there would seem to be no reason why it should not be permitted to recover damages from him. It is true that the corporation is not bound by the promoter's contracts made for it prior to its formation unless it adopts them after it comes into existence; but the corporation may be led to adopt such contracts by the promoter's non-disclosure of facts which it was his duty to the corporation to disclose. Again, the corporation may not have entrusted its property to the proinoter, nor have employed him to act

1 Nant-y-Glo \& Blaina Iron Works Co. จ. Grave, 12 Ch. D. 738, 747. 
for it; but the promoter, in fact, takes charge of its interests, and, in so doing, the law imposes upon him certain duties; if he violates these duties, to the injury of the corporation, it would seem that he should be liable to it in damages. ${ }^{1}$

$\$$ 92. Instances where promoters liable to corporation in damages. - Promoters are of course liable in damages to the corporation for their frauds under the same circumstances that individuals not promoters would be liable. If a sham contract of sale is made to a promoter for a fictitions price, whereby the corporation is induced to pay more than it would otherwise have done, an action for deceit may be maintained by the corporation against the promoter. ${ }^{2}$ The promoters may corrupt the governing body of the corporation, so as to get the corporation to enter into a contract or to purchase property, or they may aid and abet the corporate officers in defrauding the corporation. In such cases, the principle applied in Mayor, \&c. of Salford v. Lever, ${ }^{3}$ a case of agency, may

1 Bentinck v. Fenn, 12 App. Cas. 652 ; Buckley on the Companies Acts, 5th ed., 545; Boston v. Simmons, 150 Mass. 461. In England, on the winding up of a company, the Court may, under the procedure provided by the Companies Act, 1890 , assess damages against promoters for misfeasance, and in the course of the proceedings, a public examination of the promoters by the official receiver may be had, in which creditors or shareholders may take part for the purpose of eliciting information to be utilized in pending or future litigation against the promoters. While this act gives no new rights, and simply provides a summary mode of enforcing rights, which must otherwise have been enforced by action (Buckley on the Companies Acts, 5 th ed., 378), it removes a great obstacle to successful attacks upon promoters by shareholders, namely, the difficulty in getting at the facts before beginning legal proceedings. For an explanation of the word " misfeasance" as employed in the Act, see Re Kingston Cotton Mill Co., 2 Ch. (1896) 279.

2 Whaley Bridge Calico Printing Co. v. Green, 5 Q. B. D. 109.

${ }^{8} 25$ Q. B. D. 363, affirmed 1 Q. B. (1891) 168. 
be invoked. There the defendant offered to sell coals to the plaintiff corporation, through its agent, at a certain price; but the agent refused to buy at the price at which the defendant was willing to sell, unless the defendant would add to the price a shilling: a ton, which, when the bills were paid by the corporation, was to go to the agent. The fraud on the part of the defendant was this, - that "he allowed and assisted the agent of the corporation to put down a false figure as the price of the coals, in order to cheat the corporation out of a shilling a ton, which was to be paid to their own agent; and the way it was done was this, - the defendant sent in a bill to the corporation for the whole price thus increased. He got the advanced price into his hands, and then turned it over to the agent." I It was held that the corporation had two distinct and cumulative remedies, - to recover from the agent the bribe which he had received, and to recover from him and the vendor, jointly or severally, damages for the injury caused by the fraud, ${ }^{2}$ - and that in a suit for damages against the vendor no deduction was allowable in respect of what the company might recover from the agent. ${ }^{3}$ It must appear, however, in order to render a person who has contracted with a corporation, but who is in no fiduciary relation to it, liable to the corporation for giving a share of his profit to its promoters, that there was fraud on his part. If he did not know, or have reason to know, that the promoters would not make proper disclosure to the corporation, he cannot be held.*

1 Per Lord Esher.

2 See also Grand Rapids Safety Deposit Co. v. Cincinnati Safe \& Lock Co., 45 Fed. Rep. 671.

8 Lands Allotment Co. v. Broad, 13 Reports, 699.

1 Cheney v. Gleason, 125 Mass. 166. 
Article II. - Rescission by Corporation of Contracts en. teled into by it with or throvgh Promoters.

\$ 93. Rescission an elective remedy.

94. Rescission of contracts on ground of breach of duty by promoters.

95. Erlanger $v$. New Sombrero Phosphate Co., 3 App. Cas. 1218.

96. Atwool $v$. Merryweather, 5 Eq. $461, \mathrm{n}$.

97. Phosphate Sewage Co. $v$. Hartmont, 5 Ch. D. 394.

98. Caveat emptor not applicable to dealings by promoters with corporation.
§ 99. Rescission by corporation of transactions with third persons on ground of participation by such persons in frauds of promoters.

100. Election by corporation to confirm or rescind contract.

101. Right to rescind barred by laches.

102. Return of consideration received ordinarily condition precedent to right to rescind. Exceptions.

103. Partial rescission not allowed. 104. Burden of proof in suit for rescission.

§93. Rescission an elective remedy. - When a sale of property to or a contract with a corporation has been made by or through its promoters, and in the making of such sale or contract the promoters have obtained secret bribes or profits, or liave abused their power or influence, the corporation may, under certain circumstances, as we hare seen, without repudiating the sale or contract, recover from the promoters the money received by them as bribes or profits, or hold them responsible in damages. But the corporation is not confined to these remedies. In a proper case, it may, in place of pursuing such remedies, if it so elects, and if it acts seasonably, procure the transaction to be set aside altogether, and get back that with which it has parted.

$\$ 94$. Rescission of contracts on ground of breach of duty of promoters. - When the corporation is formed for the purpose of purchasing property from or entering into a contract with the promoters, the interests of the promoters and of the corporation necessarily conflict. Nevertheless, 
in such case, the promoters are not absolutely disqualified from dealing with the corporation; but being in a position of trust and confidence in relation to it, they must show, when their dealings are called in question, that they have not used their position for their own benefit only, but have acted with that degree of fairness and with that regard for the protection of the interests of the corporation which a Court of Equity exacts from persons in the relation which they occupy. They must fully disclose their position and interest and all material facts within their knowledge; and, as a rule, they must see that the directors who are to pass upon the transaction in question are competent and disinterested persons, who can and do exercise an intelligent and impartial judgment in the matter. ${ }^{1}$ If they fail in these duties, the corporation is entitled to have transactions with them rescinded.

$\S 95$. Erlanger v. New Sombrero Phosphate Co. ${ }^{2}$ - is the leading case on this point. A sale of property to the company named in this case was rescinded on the following facts. A syndicate, of which Baron Erlanger, a Paris banker, was at the head, purchased for $£ 55,000$, from the official liquidator of an insolvent company, an island said to contain valuable mines of phosphate. Erlanger, who managed the business of this purchase, then proceeded to get up a company to take over the island and to work the mines. He named five persons as directors. Two were abroad; of the three others, two were persons entirely under his control, and were furnished by him with the shares necessary to qualify them as directors. One. of these two persons had acted as a business agent for Erlanger, and the other was a personal friend. The sale of the island was made, nominally, by a person who had really no interest in the island, and was made to the

${ }^{1}$ See Sect. 26, et seq.

23 App. Cas. 1218. 
director who was the business agent of Erlanger, and who appeared as the purchaser for the company. The price was $£ 80,000$ in cash and $£ 30,000$ in paid-up shares of the company. The two directors, with whom, through Erlanger's arrangement, a third person (one entirely uninformed on the subject of the original purchase and the subsequent sale) was associated, assuming to act as director's of the company, accepted, on its behalf, the purchase. The price paid by the syndicate for the island was not disclosed. Subsequently, these facts coming to light, the company filed a bill to rescind the purchase; and a decree for rescission was made on the ground that the promoters had made an unfair and unreasonable use of the position of advantage in which they stood in relation to the company, and had withheld from the company the needful protection to which it was entitled at their lands in the transaction in question. "I cannot," said Lord Cairns, " but regard a meeting at which two of the principal directors did not and could not attend, at which one who did attend and take part in the deliberations was at once a person buying and selling, where the legal adviser present and assisting was virtually another vendor, and where the two remaining directors are not shown to have had the means of exercising, or to have exercised, any intelligent judgment on the subject, as little else than a mockery and a delusion."

§ 96. In Atwool v. Merryweather, ${ }^{1}$ - the facts were these : Merryweather was the owner of mining property, which he proposed to sell for $£ 4,000$. He applied to Whitworth to assist him in his project. The scheme concocted between them was that a company should be formed for the purpose of purchasing and working the mines, which were to be sold to such company for $£ 7,000$. Of this money, it 
was agreed that Merryweather should get $£ 4,000$, while the remaining $£ 3,000$ was to be paid to Whitworth for his assistance in getting up the company. This agreement was concealed. The company was formed under the promotion of Merryweather and Whitworth, who sent out a prospectus stating that the company had been formed to purchase and work the mines in question, and that the purchase price had been fixed at $£ 7,000$, of which $£ 4,000$ was to be paid in cash and $£ 3,000$ in shares of the company. Whitworth became a director. The company having received $£ 3,940$ for subscriptions for shares, paid the same to Merryweather, and transferred to him six hundred shares of its capital stock in part payment of the alleged price of the mines. Upon the discovery of the agreement between Merryweather and Whitworth, certain stockholders of the company brought a bill to rescind the contract of sale and purchase. A decree was made, setting aside the contract of sale and purchase, and directing that the purchase money should be repaid with interest and the share certificates given to Merryweather delivered up. ViceChancellor Wood said: "Upon such a transaction the Court will hold that the whole contract is a complete fraud. I do not in the least say that where persons with their eyes open know that the agent who secures them the bargain is going to take money for it, that would not be all right enough. If the company knew this gentleman was to have this amount as promotion money, well and good. ... But here it is a simple fraud, and nothing else. Merryweather, knowing Whitworth's position with regard to the company, and that as an honest man Whitworth was bound to tell the company what price he bought the mines for, agreed that the mines should be sold to the company for $£ 7,000$, and that the real price, $£ 4,000$, should not be disclosed to the company." 
\$ 97. In Phosphate Sewage Co. v. Hartmont, ${ }^{1}$ - the orners of a concession from a foreign government entered into a scheme to organize a company to buy the concession, which, as they knew, was, on account of their default, subject to forfeiture. They and others who were promoters of the company, and knew of the defect in the title, brought about a sale to trustees for the projected company. The trustecs transferred the concession to the company when formed, and secretly received to their own use a portion of the purchase moncy as a reward for their share in the transaction. The solicitors of the company were also solicitors for the vendors, and although they knew of the infirmity in the title, they concealed it, and the trustees neglected to secure proof as to whether the title was good. It was held that the company was entitled to a rescission of the purchase, and to a recovery of the money paid to the trustees, as money received by them as a bribe for not performing their duty.

$\S 98$. Caveat emptor not applicable to dealings by promoters with corporation. - Promoters are in a fiduciary relation to the corporation which they promote. When a fiduciary relation exists between parties, and there is any misrepresentation or concealment of a material fact, or any just suspicion of artifice, in a transaction between them or in dealings by one in behalf of the other, Courts of Equity will interpose, if the rights of innocent third parties hare not intervened, and set the transaction aside. The maxim caveat emptor does not apply here, and the rules pertaining to representations as to value, cost, opinion, etc., in cases where the parties deal at arm's-length, are not applicable. ${ }^{2}$

$\S 99$. Rescission of transactions with third persons on ground of participation by such persons in frauds of promoters. -

15 Ch. D. 394.

${ }^{2}$ Cheney v. Gleason, 125 Mass. 166 ; Cortes v. Thanhauser, 45 Fed. Rep. 731. 
When a sale of property by a non-promoter owner to a corporation has been brought about by or through the intervention of its promoters, and the promoters have, with the participation or connivance of the owner, obtained secret profits or bribes, or abused their power or influence in the transaction, the corporation is entitled to have the sale rescinded. Thus, in Lindsay Petroleum Company v. Hurd, 1 A. having two parcels and B. one parcel of land supposed to contain petroleum, it was agreed between them and $\mathrm{C}$. that $\mathrm{C}$. should pay them $\$ 10,000$ for the land, if he succeeded in forming a company for the purpose of working the oil springs, and in inducing such company to pay $\operatorname{him} \$ 13,750$, as the price of the land, out of which he was to keep $\$ 3,750$. B., accordingly, assuming the character of owner, gave to C. a conditional promise to sell the land to him for $\$ 13,750$, provided the offer was accepted within a certain time. A. wrote a letter, meant to be shown, and which was shown, to persons intending to become members of the proposed company, in which letter he recommended the purchase, not disclosing that he had any interest therein. A. and $B$. actively co-operated with $C$. throughout the whole transaction. The company, in ignorance of the agreement with C., accepted the proposal, but, having discovered the fraud, sued for a rescission of the contract. It was held that the contract must be wholly rescinded, the price repaid, and the land reconveyed. "It is difficult," said Sir Barnes Peacock, "to conceive anything more clearly fraudulent than for the owners of property to arm a person whom they know to be about to endeavor to find others to take up a purchase, whether as a company or otherwise, with a document purporting to be an offer made by themselves, as owners, to sell at a fictitious price, at which price he is to propose to other people to take up and to accept

1 L. R. 5 P. C. 221. 
that offer as if it were the real one. If that be not the real price which the owners of the property expect to get, and if they are parties to an arrangement that the intermediate agrent, who is to induce others to accept the offer, is himself to put a considerable part of the nominal price into his own pocket, without any communication of the facts, the document is a dishonest and false document upon the face of it, representing no real transaction, but evidently representing a false transaction, only in order to deccive somebody. It was used to deceive, and so used with the knowledge" of the parties. ${ }^{1}$

$\S 100$. Election by corporation to confirm or rescind contract. - A corporation wronged by its plomoters in a transaction, in the manner stated, may elect whether to affirm the transaction or to rescind it. The election once made, if made with full knowledge of the facts, is irrevocable. ${ }^{2}$ It may be express, or implied from unequivocal acts showing a determination, after discovering the facts, to retain the property or rights which have passed to it in the transaction. ${ }^{3}$ An action against the promoters to recover damages or secret profits, for example, would amount to an affirmance of the transaction, and a waiver of the right to

1 The consequences of surreptitious dealing with promoters by a third person who is endeavoring to carry out a transaction with the corporation, through its promoters, must in the ordinary case be the same as the consequences of such dealings with an agent. The principles applicable in a case of agency are illustrated in Panama \& South Pacific Telegraph Co. v. India Rubber, Gutta Percha \& Telegraph Works Co., 10 Ch. 515 . See also Smith v. Sorby, 3 Q. B. D. 552 ; Henninger v. Heald, 52 N. J. Eq. 431 ; Briggs v. Withey, 24 Mich. 136.

21 Bigelow on Fraud, 436 ; Kennedy v. Thorp, 51 N. Y. 174 ; Great Luxembourg Ry. Co. v. Magnay, 25 Beav. 586. As to the right of a majority of the stockholders to bind the minority by such election, see infra.

${ }^{3}$ See Chief Justice Shaw's definition of waiver, in Farlow v. Ellis, 15 Gray, 229; Tarkinson v. Purvis, 128 Ind. 182. 
rescind. ${ }^{1}$ Continuing to deal with the property, as, for instance, when the property is a mine, continuing to work it, after knowledge of the facts, may constitute affirmance. ${ }^{2}$ Lapse of time, after the facts are known, may be such as to furnish evidence that the corporation has determined upon affirmance; and it may be so great that it would perhaps be treated in practice as conclusive evidence of such determination. ${ }^{3}$ In Vigers v. Pike,${ }^{4}$ Lord Cottenlam said: "A man who, with full knowledge of his case, does not complain, but deals with his opponent as if he had no case against him, builds up from day to day a wall of protection for such opponent, which will probably defeat any future attack upon him."

$\S 101$. Right to rescind barred by laches. - Although the corporation has not affirmed the transaction, still, in order to obtain rescission, on any of the grounds stated, it must be free from laches; in other words, it must bring its suit for relief seasonably. The right to rescind remains only for a reasonable time after the discovery of the facts, ${ }^{5}$ and "the law is well settled that when the question of laches is at issue, the plaintiff is chargeable with such knowledge as he might have attained upon inquiry, provided the facts already slown by him were such as to put a man of ordinary intelligence on inquiry." 6 From the nature of the subject, it is

1 Sanger v. Wood, 3 Johns Ch. (N. Y.) 416.

2 Vigers v. Pike, 8 Cl. \& F. 562; Morgan v. Thetford, 3 Ill. App. 323; Barr v. New York, Lake Erie \& Western R. R. Co., 125 N. Y. 263. Compare the judgments of Lord Cairns and Lord Blackburn in Erlanger v. New Sombrero Phosphate Co., 3 App. Cas. 1218.

${ }^{8}$ Clough v. London \& Northwestern Ry. Co., 7 Ex. at p. 35; Schiffer v. Dietz, 83 N. Y. 300; Williamson v. New Jersey Southern R. R. Co., 29 N. J. Eq. 311 ; Davis v. Stuard, 99 Penn. 295.

$48 \mathrm{Cl}$. \& F. 562.

5 Royal Bank of Liverpool v. Grand Junction Railroad, 125 Mass. 490 ; In re Pinto Silver Mining Co., 8 Ch. D. 273.

- Foster v. Mansfield R. R. Co., 146 U. S. 88. 
not practicable to state a precise rule as to what is or is not unicasonable delay. This must be decided according to the circumstances of each case, with a view to doing practical justice between the parties. But it may be laid down that no delay for the purpose of enabling a party to speculate upon the chances which the future may give him of deciding profitably to himself whether he will abide by his bargain or rescind it, is allowed in a Court of Equity. ${ }^{1}$ This is especially applicable where the subject-matter of the controversy is property of a speculative character or of fluctuating value. In Twin Lick Oil Company v. Marbury, ${ }^{2}$ relief was refused, the suit having been brought four years after the sale of the property in question, which consisted of oil lands subject to marked fluctuations in value. ${ }^{3}$ The death of parties or witnesses, or the loss of evidence that might have been obtained, if suit had been seasonably brought, is of great moment in the question of laches. ${ }^{4}$ of course, if, prior to the suit for rescission, an innocent third party has acquired an interest which would be affected by the decree, rescission cannot be had. ${ }^{5}$

$\S 102$. Return of consideration received, ordinarily condition precedent to right to rescind. - Exceptions. - Restoration of the thing received by the injured party is, as a rule, a condition preccdent to rescission. In some cases the return may be of an equivalent in place of the identical thing re-

1 Miller, J., in Twin Lick Oil Co. v. Marbury, 91 U. S. 592. Compare the opinions in Erlanger v. New Sombrero Phosphate Co., 3 App. Cas. 1218.

291 U. S. 587.

${ }^{3}$ See also Neblett v. Macfarland, 92 U. S. 101, 104 ; Castner v. Walrod, 83 Ill. 171 ; Cox v. Montgomery, 36 Ill. 396 ; Jones v. Smith, 33 Miss. 215 ; Lindsay Petroleum Co. v. Hurd, L. R. 5 P. C. 221.

${ }_{4}^{4}$ Jenkins v. Pye, 12 Peters, 241; Canpau v. Van Dyke, 15 Mich. 371 ; Hatcher v. Hall, 77 Va. 573.

${ }^{5}$ Stevenson v. Newnham, 13 C. B. 285 ; Pease v. Gloaheck, L. R. 1 P. C. 219. 
ceived. Thus, on rescission of a sale of merchandise, either the original articles, or their number, quantity, and value, in kind, should be restored. If the property is entirely worthless, it need not be restored. ${ }^{2}$ In Phosphate Sewage Company v. Hartmont, 3 the promoters of a company sold to it a concession from a foreign gorernment which was subject to forfeiture. On a bill to rescind the sale on account of fraud on the part of the promoters, the objection that the company had not re-conveyed, or tendered a re-conveyance of the concession, was overruled on the ground that the concession was worthless, the forfeiture to which it was subject having taken place. But the rule requires that the other party shall be substantially restored to his status quo; therefore if the property has the slightest value, or its loss may be a disadvantage in any way, even if it have no intrinsic or market value, it must be returned. ${ }^{*}$ The question as to the worthlessness of the property may be a question of law, as in the case of forged bank-notes or other counterfeit securities, or of a title judicially determined to be invalid. Ordinarily, however, it is a question of fact, as in a case of shares of stock in a company alleged to be insolvent. ${ }^{5}$ The mere fact that the property has fallen in value since the transaction in question will not prevent rescission. ${ }^{6}$

$\S 103$. Partial rescission not allowed. - The rescission must be in toto; a transaction cannot be rescinded in part

1 Smith v. Brittenham, 109 Ill. 540; Bodley v. McChord, 4 J. J. Marsh. (Ky.) 475.

2 Perley v. Balch, 23 Pick. 283 ; Snow v. Alley, 144 Mass. 551 ; Babcock v. Case, 61 Penn. 427 ; Haase v. Mitchell, 58 Ind. 213.

${ }^{8} 5$ Ch. D. 394.

4 Snow v. Alley, 144 Mass. 551 ; Gay v: Alter, 102 U. S. 79 ; Cushing v. Wyman, 38 Me. 589; Manahan จ. Noyes, 52 N. II. 232; Moriarty v. Stofferan, 89 Ill. 523 ; Hunt v. Silk, 5 East, 449; Clarke v. Dickson, 1 E. B. \& E. 148.

5 Beetenn v. Burkholder, 69 Penn. 249.

- Neblett v. Macfarland, 92 U. S. 101. 
and stand good for the residue. ${ }^{1}$ To permit the value of property to be handed over in money, in place of the propcrty itself, would in most cases amount to a partial rescission. In Higgins v. Lansingh, ${ }^{2}$ it was found that Higgins, one of the managers of a company, had improperly sold land to it for a price largely in excess of the market value. The trial court decreed that the excess over the market value should be refunded to the company, the company retaining the land. This was reversed on appeal. "It is not questioned," said the Appellate Court, " that if the price charged to the company by Higgins were exorbitant, or so much in excess of the market value as to make the transaction unfair or oppressive to the company, a Court of. Equity would, upon application made in apt time, set it aside, he being at the time of the sale one of the managers of the company; but it cannot be said that because he paid only $\$ 24,000$ for the land, he was under any obligations to sell it to the company for anything like that amount. He was not a manager or other officer of the company when he bought it. . . He had the right to purchase the land, and to keep it or sell it to the company, as he saw fit. But if it be conceded that the price was so excessive as to make the sale unfair and oppressive, can appellees or the company now have the sale rescinded without restoring the land to Higgins? We think not. . . . It might well be that Higgins would not have sold to the company for what the land would have brought in 1873 in the market. He doubtless bought it for a speculation, and he had a right to keep it until he could get lis price for it, and we know of no power in a Court of Equity to compel him to sell the land for its market value; and to undertake now to fix that value as the measure of

1 Sheffield Nickel Co. v. Unwin, 2 Q. B. D. 214, 223 ; Grant v. Law, 23 Wisc. 99 ; Rand $\nabla$. Webber, 64 Me. 191.

2154 Ill. 301, 378. 
pay for this land would seem to place in jeopardy the rights of all the parties, while to rescind the sale in toto would probably be of no benefit to either. . . We are of the opinion that neither the complainant nor the company is entitled to rescission."

$\S 104$. Burden of proof in suit for rescission. - The rule as to the burden of proof was thus laid down by Lord Watson in Bentinck v. Fenn: ${ }^{1}$ "In a case where rescission is asked, and it is not denied that at the time when the sale was made the seller failed in breach of his duty to disclose his interest, the onus rests upon him to prove, if he desires to maintain the transaction, that his interest became known to the purchaser at a subsequent period, and that the purchaser, either expressly or by plain implication, elected to uphold the transaction. But the case is rery different when a defendant is charged with making undue profits in the dark, at the expense of the purchaser, or with fraudulent concealment of facts which has led to loss on the part of the purchaser. The onus probandi then is upon the plaintiff, - the usual rule of law must apply. I know of no case where by implication of law the duty of clcaring himself from an imputed fraud rests on the defendant."

112 App. Cas. at p. 666. 


\section{CHAPTER VI.}

SUITS BY SHAREHOLDERS TO COMPEL REDRESS FOR WRONGS BY PROMOTERS TO THE CORPORATION.

$\S 105$. As general rule suit can be brought only by corporation.

106. Exceptions to this rule.

107. Proof necessary to establish disability of corporation to sue.

108. Transactions on account of which shareholders may or may not bring suit.

109. Exposition of rule on this subject by Lords Justices James and Mellish.

110. Right of minority shareholders to sue to rescind transaction voidable for fraud, when majority are the wrong-doers.

111. Atwool $v$. Merryweather, 5 Eq. 464, $n$.

112. Mason $v$. Harris, $11 \mathrm{Ch} . \mathrm{D}$. 97.

113. Right of minority, where majority are not the wrong-doers, to sue to rescind contracts voidable for fraud.
$\S 114$. Foss $v$. Harbottle, 2 Hare, 461.

115. Right of minority to sue to rescind a voidable transaction where there is no fraud.

116. Right of minority to sue for recovery of secret profits obtained by promoters.

117. Majority not allowed to retain profits wrongfully obtained at expense of minority.

118. Right of minority to sue for recovery of promoter's profits on sale to corporation at fraudulently excessive price.

119. Shareholder whose shares have been voted on in favor of a transaction cannot maintain suit based upon it.

120. Rule in Federal Courts.

121. Slareholders' suit may be barred by laches.

122. Forn of shareholders' suit.Necessary parties.

$\S 105$. General rule that suit can be brought only by the corporation. - As a general rule, suits to obtain redress for wrongs to the corporation, or to enforce corporate rights, must be brought by the corporation itself through its regularly appointed agents, and it is not competent for the shareholders to sue for such purpose in their own names or in the corporate name. The management of the 
affairs of a corporation is by law and by the agreement of the shareholders vested in its duly constituted agents, ordinarily in a board of directors, with whom accordingly must rest the decision of the question of the expediency of bringing corporate suits." "It would be a doctrine attended with very serious consequences," said Mr. Justice Miller, "if every individual shareholder, assuming the place of the corporation, could decide for it when actions should be brought to vindicate its supposed right. Each one of the shareholders might elect to claim a remedy, and resort to a tribunal different from those chosen by every other, and use the Court of Equity to enforce his views, regardless of the duly constituted officers and all other parties having interests, rights, and powers equal to his own. In such a struggle the real interests of the corporation might be entirely sacrificed." 2

$\S 106$. Exceptions to the rule. - This general rule has, however, its exceptions. When it is duly shown that the corporation is disabled from asserting its rights in the courts, shareholders are permitted to bring suit, provided the suit is of such a nature that it clearly ought to be brought in order to conserve the equitable rights of shareholders, and to prevent a failure of justice.

$\S 107$. Proof necessary to establish disability of corporation to sue. - In order to establish the disability of the corporation, the following facts must be alleged and proved:

First. That a demand has been made upon the directors to bring suit and that they have refused so to do; or, that the directors are the wrong-doers in the transaction com-

1 Smith v. Hurd, 12 Met. 371; Abbott v. Merriam, 8 Cush. 588; Lord v. Copper Miners Company, 2 Phill. 740 ; Foss v. Harbottle, 2 Hare, 461; Allen v. Curtis, 26 Conn. 456; Jones v. Johnson, 10 Bush (Ky.), 649; Robinson v. Smith, 3 Paige, 222.

2 Samuel v. Holladay, 1 Woolw. (U. S. C. Ct.) 400. 
plained of, or are in collusion with the wrong-doers, in which case a demand is unnecessary, not only because ordinarily it would be a futile formality, but because, under such circumstances, it would be a perversion of justice to allow the directors to conduct the litigation. A demand and refusal, or the facts relied on to excuse a demand, must be alleged and proved. ${ }^{1}$

Second. That due effort has been made, unsuccessfully, to bring about the choice of new directors competent and willing to institute and carry on the desired suit. "Annual meetings," said Mr. Justice Wells in Brewer v. Boston Theatre Co., "even if special meetings are impracticable, secure to the corporation ample means of correcting abuses practised by their officers, so far as correction is desired by the majority or by the corporation as a body. It is not to be presumed that the body of the corporation will tolerate a wrong in their elective officers, by which they are themselves defrauded." It should also be noted that a corporation has an implied power incident to its existence as a corporation, and independent of statutory or charter provisions, to remove a director for just cause. The power of removal is incident to the power of appointment, and it may therefore be exercised by a majority of the shareholders. ${ }^{3}$ But if the delay incident to the effort to procure

1 Robinson v. Smith, 3 Paige, 222; Peabody v. Flint, 6 Allen, 52; Dunphy v. Traveller Newspaper Association, 146 Mass. 495; Hersey v. Veazie, 24 Me. 9 ; March v. Eastern R. R. Co., 40 N. H. 548; Heath v. Erie Ry. Co., 8 Blatch. 347; Wheeler v. Pullman Iron \& Steel Co., 143 Ill. 197; Farwell v. Great Western Telegraph Co., 161 Ill. 522; Bjorngaard v. Goodhue County Bank, 49 Minn. 483; Koop v. Bohmrich, 49 N. J. Eq. 82 ; Boyd v. Sims, 87 Tenn. 771; Miller v. Murray, 17 Col. 408 ; Allen v. Curtis, 26 Conn. 456 ; Alexander v. Searcy, $81 \mathrm{Ga} .536$. See also cases cited in note 1 , page 117.

2104 Mass. at p. 393.

${ }^{8}$ Neall v. Hill, 16 Cal. 145; Ohio v. Bryce, 7 Ohio, 82; Bayless v. Orne, Freem. Ch. (Miss.) 161; Adamantine Brick Co. v. Woodruff, 4 McArthur (D. C.), 318; Auburn Academy v. Strong, Hopk. (N. Y.) 
the election of new directors would be prejudicial to the remedy sought, or, if the majority of the shareholders are themselves concerned in the wrong-doing complained of, or in collusion with the wrong-doers, or it may be inferred with reasonable certainty on the facts shown that they would disregard the wishes of the minority in the matter, then an effort of the nature stated is not requisite. The facts relied on to excuse such effort must be alleged and proved. ${ }^{1}$

278; Burr v. McDonald, 3 Gratt. (Va.) 215; Fawcett v. Charles, 13 Wend. 473; People v. Higgins, 15 Ill. 110; State v. Trustees of Vincennes University, 5 Ind. 77; Lord Burns' Case, 2 Strange, 820.

1 Brewer v. Boston Theatre Co., 104 Mass. 378; Landis v. Sea Isle. City Hotel Co. (N. J.), 31 At. Rep. 755 ; Dunphy v. Traveller Newspaper Association, 146 Mass. 495; Wallace v. Lincoln Savings Bank, 89 Tenn. 630 ; Eschweiler v. Stowell, 78 Wisc. 316; Rathbone v. Parkersburg Gas Co. (Va.) 8 S. E. Rep. 570 ; Hawes v. Oakland, 104 U. S. 450; Tuscaloosa Mfg. Co. v. Cox, 68 Ala. 71; Mozley v. Alston, 1 Phill. 790; Russell v. Wakefield Waterworks Co., 20 Eq. 474; Gray v. Lewis, 8 Ch. 1035; Mason v. Harris, 11 Ch. D. 97; Menier v. Hooper's Telegraph Works, 9 Ch. 350; Moore v. Silver Valley Mining Co., 104 N. C. 534; Miller v. Murray, 17 Col. 408; Hersey v. Veazie, 24 Me. 9; Merchants' \& Planters' Line v. Wagoner, 71 Ala. 581.

In Hawes v. Oakland, 104 U. S. 450, Mr. Justice Miller said: "Before the shareholder is permitted in his own name to institute and conduct a litigation which usually belongs to the corporation, he should show to the satisfaction of the Court that he has exhausted all the means within his reach to obtain, within the corporation itself, the redress of his grievance, or action in conformity to his wishes. He must make an earnest, not a simulated effort with the managing body of the corporation to induce remedial action on their part, and this must be made apparent to the Court. If time permits, or has permitted, he must show, if he fails with the directors, that he has made an honest effort to obtain action by the stockholders as a body, in the matter of which he complains. And he must show a case, if this is not done, where it could not be done, or it was not reasonable to require it. The effort to induce such action as complainant desires on the part of the directors, and of the shareholders when that is necessary, and the cause of failure in these efforts, shonld be stated with particularity." These requirements were subsequently embodied in the rule 
$\S 108$. Transactions on account of which shareholders may or may not bring suit. - The disability of the corporation to sue having been proved, it is essential, in order to establish the right of minority shareholders to begin proceedings, to show that the transaction on account of which it is desired to bring suit, is of such a nature, and that the eircumstanees are sueh, that it is not competent for the majority of the shareholders as against the minority to determine that no action sliall be taken in the matter by the corporation. "It would be contrary to the fundamental principles of corporate organization," said Mr. Justice Knowlton in Dunphy v. Traveller Newspaper Association, ${ }^{1}$ " to hold that a single shareholder ean at any time launch the corporation into litigation to obtain from another what he deems to be due to it, or to prevent methods of management which he thinks unwise. Intelligent and honest men differ upon questions of business poliey. It is not always best to insist upon all one's rights ; and a corporation acting by its direetors, or by vote of its members, may properly refuse to bring a suit which one of its stockholders believes should be prosecuted. In such a ease the will of the majority must control. It is only when the action of a corporation in refusing to proceed at the request of a stock-

of practice in the United States Courts known as the Ninety-fourth Equity Rule, which provides, among other things, that every bill brought by one or more stockholders in a corporation, and other parties, founded on rights which may properly be asserted by the corporation, must "set forth with particularity the efforts of the plaintiff to secure such action as he desires on the part of the managing directors or trustees, and, if necessary, of the shareholders, and the causes of his failure to obtain such action." When, however, the directors are the wrong-doers, or in collusion with the wrong-doers, no demand on them to bring suit is required. Young v. Alhambra Mining Co., 71 Fed. Rep. 810; Excelsior Pebble Phosphate Co. $\nabla$. Brown, 74 Fed. Rep. 323.

1146 Mass. at p. 497. 
holder is fraudulent as against him, or in disregard of his rights, that he can maintain a suit in his own name in the corporate right. The Court cannot interfere in the management of corporations, in matters which are properly within their discretion, so long as their discretion is fairly exercised, and it is always assumed, until the contrary appears, that they and their officers obey the law, and act in good faith towards all their members."

$\S 109$. Exposition of rule by Lords Justices James and Mellish. - Perhaps the most useful exposition of the rule on the point stated in the preceding section, to be found in the books, is that contained in the judgments of Lords Justices James and Mellish; in MacDougall v. Gardiner. ${ }^{1}$ "I think," said Lord Justice James, "it is of the utmost importance in all these companies, that the rule, which is well known in this Court as the rule in Mozley v. Alston, ${ }^{2}$ and Lord v. Copper Miners Company, ${ }^{3}$ and Foss v. Harbot$t l e,{ }^{4}$ should always be adhered to ; that is to say, that nothing connected with internal disputes between the shareholders is to be made the subject of a bill by some shareholder in behalf of himself and others, unless there be something illegal, oppressive, or fraudulent - unless there is something ultra vires on the part of the company, qua company, or on the part of the majority of the company, so that they are not fit persons to determine it; but that every litigation must be in the name of the company, if the company really desire it. Because there may be a great many wrongs committed in a company - there may be claims against directors, there may be claims against officers, there may be claims against debtors, there may be a variety of things, which a company may be well entitled to complain of, but which, as a matter of good sense,
11 Ch. D. 13.
32 Phill. 740.
21 Phill. 790.
42 Hare, 461. 
they do not think it right to make a subject of litigation, and it is the company, as a company, which has to determine whether it will make anything that is wrong to the company a subject-matter of litigation, or whether it will take steps itself to prevent the wrong being done."

Lord Justice Mellish, observing that in companies things are often done which ought not to be done, goes on to say: "Now, if that gives a right to every member of the company to file a bill to have the question decided, then, if there happens to be one cantankerous member, or one member who loves litigation, everything of this kind will be litigated, whereas if the bill be filed in the name of the company, then, unless there is a majority who really wish for litigation, the litigation will not go on. Therefore holding that such suits must be brought in the name of the company does certainly greatly tend to stop litigation. In my opinion, if the thing complained of is a thing which in substance the majority are entitled to do, or if something has been done irregularly which the majority of the company are entitled to do legally, there can be no use in having a litigation about it, the ultimate end of which is only that a meeting has to be called, and then, ultimately, the majority gets its wishes. Is it not better that the rule should be adhered to that if it is a matter which the majority are masters of, the majority in substance shall be entitled to have their will fulfilled? If it is a matter of that nature, it only comes to this, that the majority are the only persons who can complain that a thing which they are entitled to do has been done irregularly, and that, as I understand it, is what has been decided by the cases of Mozley v. Alston and Foss v. Harbottle. In my opinion, that is the rule that is to be maintained. Of course, if the majority are abusing their powers, and are depriving the minority of their rights, that is an entirely different thing, and there the minority 
are entitled to come before this Court to maintain their rights; but if what is complained of is simply that something which the majority are entitled to do has been done or undone irregularly, then I think it is quite right that nobody should have a right to set that aside, or to institute a suit in chancery about it, except the company itself."

$\S 110$. Right of minority shareholders to sue to rescind transaction voidable for fraud, when majority are the wrong-doers. - A shareholder's suit to obtain redress for wrongs done the corporation by or through promoters would ordinarily seek one of two remedies, namely, - rescission of the transaction brought in question, or a recovery of secret profits obtained by the promoters. When rescission of a transaction is sought on the ground of fraud, and the majority of the directors and shareholders are the wrong-doers, or in eollusion with the wrong-doers, so that they are not fit persous to determine as against the minority the election of the corporation to affirm or set aside the transaction, the right of the minority to bring suit seems clear. ${ }^{1}$

$\S$ 111. In Atwool v. Merryweather, ${ }^{2}$ - where a fraudulent sale of mines was made to a company through promoters, the purchase of the mines being the only thing for which the company was incorporated, and the whole inception of the company being simply a scheme to confirm a purchase as made for $£ 7,000$, which was made for $£ 4,000$, the majority of the shares being owned or controlled by the

1 Meeker v. Winthrop Iron Co., 17 Fed. Rep. 48; Meyer v. Staten Island Ry. Co., 7 N. Y. St. Rep. 245; Farmers' Loan \& Trust Co. v. New York \& Northern Ry. Co., 150 N. Y. 410. The last cited case establishes the right of minority shareholders to defend a suit against the corporation on an executory contract when the corporation is, through the fraud of the majority shareholders, disabled from making a proper defence.

$25 \mathrm{Eq} .464, \mathbf{n}$. 
wrong-doers, it was held that the minority shareholders might sue to set the purchase aside. "If I were to hold," said the Vice-Chancellor, "that no bill could be filed by sharcholders to get rid of the transaction on the ground of the doctrine of Foss v. Harbottle, it would be simply impossible to set aside a fraud committed by a director under. such circumstances, as the director obtaining so many shares by fraud would always be able to outvote everybody else."

$\S 112$. In Mason v. Harris, ${ }^{1}$ - the defendant Harris was a promoter of a company formed to purchase from him a certain business and property employed therein. It was agreed that the company should pay a stated price for the property, and that for the good-will of the business it should pay a sum equal to the profits of the business for the preceding year. The purchase price was payable partly in money and partly in paid-up shares of the company. Harris represented that the profits of the business for the two years in question had amounted to $£ 3,511$, and the transaction was carried out on that basis. Subsequently, it was discovered that Harris's representation was false and fraudulent, and that the profits had been but a little orer $£ 300$ a year. Two shareholders of the company then brought suit to set aside the purchase, alleging that the board of directors was controlled by Harris, and refused to take any steps with reference to the matter complained of, and that Harris possessed such a preponderance of votes that no steps could successfully be taken within the company to obtain a remedy for the wrong committed. A demurrer to the bill was orerruled. "As a general rule," said Jessel, M. R., "the company must sue in respect of a claim of this nature; but general rules have their exceptions, and one exception to the rule requiring the company to be plaintiff

111 Ch. D. 97. 
is, that where a fraud is committed by persons who can command a majority of votes, the minority can sue. The reason is plain, as unless such an exception were allowed, it would be in the power of a majority to defraud the minority with impunity. If the majority were to make a fraudulent sale and put the money into their own pockets, would it be reasonable to say that the majority could confirm the sale?" James, L. J., said: "I am of the same opinion. No judge has ever laid down more strongly than $I$ the rule that in general in these cases the company must be the plaintiff. But an exception to that rule was established by Atwool v. Merryweather, ${ }^{1}$ and this case is within it. It has been suggested that the Court has some means of directing a meeting to be called in which the corrupt shareholders shall not be able to vote. If the Court had any such power, that mode of proceeding might furnish the best remedy in cases of this nature, but I cannot see how any directions for holding such a meeting could be given."

$\S 113$. Right of minority, where majority are not the wrongdoers, to sue to rescind contracts voidable for fraud. - When rescission of a transaction is sought on the ground of fraud, and the majority shareholders are not the wrong-doers or in collusion with the wrong-doers, minority shareholders have no standing to sue for rescission, unless the ratification of the transaction would be illegal, fraudulent, or oppressive toward them. Rescission involves the surrender of property, or the release of rights acquired by the corporation through the transaction sought to be rescinded. The corporation, by the vote of the majority of its shareholders acting fairly, in good faith, and intra vires, is entitled to determine for itself exclusively, whether it will retain or release property or rights thus acquired, although it thereby precludes, or renders ineffectual, all proceedings 
against partics who may have made illegal or fraudulent gains out of the transaction. 1

$\S$ 114. Thus, in Foss v. Harbottle, ${ }^{2}-$ a demurrer was sustained to a bill filed by two shareholders in a company in bchalf of themselves and other shareholders, against the directors of the company and others, charging the defendants with concerting and effecting various fraudulent and illegal transactions, whereby the property of the company was misapplicd and wasted, and praying that the defendants might be decreed to make good to the company the losses and expenses occasioned by the acts complained of. One alleged ground of complaint was that the defendant directors had, in their character of directors, purchased their own lands of themselves for the use of the company, and had paid for them, or, rather, taken to themselves, out of the moneys of the company, a price exceeding the value of such lands. This "ground of complaint," said the ViceChancellor, "is one which though it might prima facie entitle the corporation to rescind the transactions complained of, does not absolutely and of necessity fall under the description of a void transaction. The corporation might elect to adopt those transactions and hold the directors bound by them. In other words, the transactions admit of confirmation at the option of the corporation, ... whilst the Court may be declaring the acts complained of to be void at the suit of the present plaintiffs, who in fact may be the only proprietors who disapprove of them, the governing body of proprietors may defeat the decree by lawfully resolving upon the confirmation of the very acts which are the subject of the suit. The very fact that the governing body of proprictors assembled at the special general

1 Brewer v. Boston Theatre Co., 104 Mass. at p. 394 ; Clinch v. Financial Corporation, 5 Eq. at p. 482.

22 Hare, 461. 
meeting may so bind even a reluctant minority, is decisive to show that the frame of this suit cannot be sustained whilst that body retains its functions." 1

$\$ 115$. Right of minority to sue to rescind a voidable trans. action where there is no fraud. - When a transaction with promoters is voidable by the corporation, on account of the personal interest of the promoters, but there is no actual fraud or unfairness in it, it would seem that although they own or control a majority of the stock, and thus are enabled to outvote the minority, the latter are not entitled to sue to rescind the transaction.2 Thus in North West Transportation Co. v. Beatty, ${ }^{3}$ the plaintiff, as a sliareholder in the North West Transportation Company, sued in behalf of himself and all the other shareholders of the company, except those who were defendants. The defendants were the company, and five shareholders who, at the commencement of the action, were the directors of the company. The claim in the action was to set aside a sale made to the company by the defendant Beatty, one of the directors of a steamer called the "United Empire," of which, previously to such sale, he was the sole owner.

1 It did not appear by the bill that the company was entitled to claim the profits made by the directors on the sale to the company.

${ }^{2}$ Hill v. Nisbett, 100 Ind. 341 ; Havens v. Hoyt, 6 Jones Eq. (N. C.) 115 ; Shaw v. Davis, 78 Md. 308. In Gamble v. Queen's County Water Co. 123 N. Y. 99, it was held that one who has entered into a voidable contract with a company is entitled to exercise his voting power as a shareholder in general meeting to ratify such contract. His doing so cannot be deemed oppressive by reason of his individually possessing a majority of the shares acquired in a manner authorized by the constitution of the company. But if the action resulting from his vote is a wanton or fraudulent destruction of the rights of the minority, it may be subjected to the scrutiny of a Court of Equity at the suit of the minority shareholders.

812 App. Cas. 589. 
It appeared that a by-law for the purchase of the "United Empire" from Beatty was passed by the directors. Subsequently this by-law was adopted at a meeting of the sharcholders by a majority of votes, and the steamer was purchased by the company. Beatty held and voted a majority of the shares of the company. The contract was a fair one, within the powers of the company, and free from imputation of fraud. It was held that the defendant was entitled to exercise his voting power as a sharcholder in general meeting to ratify the contract, and that accordingly the plaintiff's action was not maintainable.

$\S 116$. Right of minority to sue for recovery of secret profits obtained by promoters. - When secret profits have been obtained by promoters under circumstances entitling the company to claim them, the right of the majority shareholders to determine, as against the minority, that no steps shall be taken for their recovery, must depend upon whether or not that determination would be fraudulent or oppressive towards the minority. If it would have been competent for the majority of the shareholders, in the first instance, in case the profits had been disclosed, instead of concealed, to allow them, then, doubtless, it would be within the power of a disinterested majority, on discovering the facts, to confirm the transaction.

$\S 117$. Majority not allowed to retain profits wrongfully obtained at expense of minority. - The majority will not be allowed to put into their own pockets profits wrongfully obtained at the expense of the minority. ${ }^{1}$ This is illustrated in Menier r. Hooper's Telegraph Works. ${ }^{2}$ A bill was filed in this case by the plaintiff, a minority shareholder, in behalf of himself and all other shareholders of

\footnotetext{
1 Hazard v. Durant, 11 R. X. 195 ; First National Bank of Fort Scott v. Drake, 29 Kan. 311.

29 Ch. 350.
} 
the European and South American Telegraph Company, except such of them as were defendants, against the company and a company called Hooper's Telegraph Works and others. The European Company was incorporated with the object of carrying out an agreement between the plaintiff and others for constructing a submarine telegraph under certain concessions from foreign governments. Hooper's Company was to contract for laying down the European Company's telegraph cable from Portugal to Brazil. Hooper's Company owned a majority of the shares of the European Company. One of the concessions for making the telegraph had been granted to the Baron de Maua, who was at one time chairman of the European Company, and this concession was claimed by that company, and a bill was filed by it, praying a declaration that he was a trustee of the concession for it. Hooper's Company procured an abandonment of this suit, and the winding up of the Enropean Company. As a part of this transaction, an arrangement was made by Hooper's Company, the Baron de Maua, and a company in which he was interested, by reason of which it was to the advantage of Hooper's Company and the Baron de Maua, that the agreement with the European Company should be put an end to, in order that Hooper's Company might sell to the Baron de Maua's company the cable it was making for the European Company. The bill prayed that Hooper's Company might be declared not entitled to the benefit of the profits derived by it from the abandonment of the suit and other arrangements as above stated, and might be declared a trustee of those profits for the plaintiff and the other shareholders of the European Company. A demurrer to the bill was overruled. "It so happens," said Mellish, L. J., " that Hooper's Company are the majority in this company, and a suit by this company was pending which 
might or might not turn out advantageous to this company. The plaintiff says that Hooper's Company, being the majority, have procured that suit to be settled upon terms favorable to themselves, they getting a consideration for settling it in the shape of a profitable bargain for the laying of a cable. I am of opinion that although it may be quite true that the shareholders of a company may vote as they please, and for the purpose of their own interests, yet that the majority of shareholders cannot sell the assets of the company, and keep the consideration, but must allow the minority to hare their share of any consideration which may come to them. I also entirely agree that, under the circumstances, the suit is properly brought in the name of the plaintiff on behalf of himself and all the other shareholders."

$\S 118$. Right of minority to sue for recovery of promoter's profits on sale to corporation at fraudulently excessive price. - If secret profits have been obtained by promoters by fraudulently swelling the purchase price of property sold to the company, an excessive price having been charged in order that such profits might be secured at the expense of the corporation, it would ordinarily not be competent for the majority, as against dissenting shareholders, to prevent a suit for their recovery. Especially would this be so when the promoters themselves owned or controlled a majority of the shares, for to hold otherwise would be to permit the majority fraudulently to enrich themselves at the expense of the minority. In Mason v. Harris, ${ }^{1}$ where a promoter, by means of fraudulent misrepresentations, sold property to a company at a great over-value, and a suit was brought by minority shareholders to rescind the sale, it was said by Jessel, M. R., that a recovery ought to be had by the company, even if the purchase were not rescinded, but affirmed.

111 Ch. D. 97. 
$\S 119$. Shareholder whose shares have been voted on in favor of a transaction cannot maintain suit based upon it. A shareholder has no standing to bring suit, if his shares have been voted on by a previous holder in favor of the transaction complained of, or if, at the time when the transaction was entered into, the then holder of such shares participated or acquiesced in the transaction. " "This," observes Mr. Cook, " is a very important principle of law, and defeats many suits instituted by stockholders to remedy past wrongs." 2

$\S 120$. Rule in Federal Courts. - In the Federal Courts, a shareholder cannot maintain a suit to obtain redress for a wrong to the corporation committed before he became a shareholder, unless his share has devolved on him by operation of law. By Equity Rule 94, "Eviery bill brought by one or more stockholders in a corporation against the corporation and other parties, founded on rights which may properly be asserted by the corporation, must be verified by oath, and must contain an allegation that the plaintiff was a shareholder at the time of the transaction of which he complains, or that his share has devolved on him since by operation of law." 3

$\S 121$. Shareholder's suit may be barred by laches. - The right of shareholders by suit to complain of transactions with the corporation, which are voidable on account of the actual or constructive fraud of promoters, may be lost by laches. If the delay has been unreasonable and so great

1 In re Syracuse, Chenango, \& New York R.R. Co., 91 N. X. 1; Barr จ. New York, Lake Erie, \& Western R.R. Co., 125 N. Y. 263; Wood v. Cory Waterworks Co., 44 Fed. Rep. 146 ; Brown v.,Duluth, \&c. R. R. Co., 53 Fed. Rep. 889 ; Clark v. American Coal Co., 86 Iowa, 451. It is held in Georgia that a subsequent shareholder cannot in any event complain, Alexander v. Searcy, 81 Ga. 536.

${ }^{2}$ Cook on Stockholders, Sect. 735.

8 Dimpfel v. Ohio \& Mississippi R. R. Co., 110 U. S. 209. 
as to constitute acquiescence, or if other rights have intervened which it would be inequitable to destroy, a Court of Equity will refuse to grant the relief sought. What will constitute such laches as to preclude relief must depend upon the circumstances of each case. ${ }^{1}$

$\$ 122$. Form of shareholder's suit. - Necessary parties. When shareholders sue to assert corporate rights, or to remedy corporate wrongs, they must bring suit in behalf of themselves and all other shareholders not made parties defendant who may come in and join in the suit. A shareholder does not sue in his own right. 2 The real complainant is the corporation, which is represented in the prosecution of the suit by the shareholder as the nominal complainant. The corporation, therefore, is an indispensably necessary party defendant, in order that it may be bound by the decree, and that the relief prayed for, if obtained, may be decreed to it. ${ }^{3}$

1 Catlin v. Green, 120 N. Y. 441 ; Watt's Appeal, 78 Penn. 370 ; Davis v. Gemmell, 70 Md. 356 ; Peabody v. Flint, 6 Allen, 52 ; Dunphy v. Traveller Newspaper Association, 146 Mass. 495; Snow v. Boston Blank Book Mfg. Co., 153 Mass. 456, 158 Mass. 325; Gregory v. Patchett, 33 Beav. 595; Dimpfel v. Ohio \& Mississippi R. R. Co., 110 U. S. 209.

2 Bailey v. Birkenhead Railway Co., 12 Beav. 433 ; Winsor v. Bailey, 55 N. H. 218 ; Cunningham v. Pell, 5 Paige, 607.

3 Willoughby v. Chicago Junction Railways, 50 N. J. Eq. 656 ; 3 Pomeroy's Eq. Juris. Sect. 1095. 


\section{CHAPTER VII.}

LIABILITY OF PROMOTERS TO ACCOUNT FOR PROFITS, COMMISSIONS, AND GIFTS, OR IN DAMAGES TO SHAREHOLDERS OF THE CORPORATION.

Article I. - Liability to account for Profits, Gifts, and Commissions.

Article II. - Liability in Damages when in a Fiduciary Position toward Shareholders.

Article III. - Liability in Damages when not in a Fiduciary Position toward Shareholders.

Article I. - Liability to Account for Profits, Gifts, and Commissions.

\$ 123. Effect of invitation by promoters to others to join them in acquiring property, and to become shareholders in corporation to be formed to purchase it.
$\S$ 124. Emery $v$. Parrott, 107 Mass. 96.

125. Getty $v$. Devlin, 54 N. Y. $403 ; 70$ N. Y. 504.

126. Rule as to joinder of plaintiffs in suit against pro. moters for an accounting.

$\S 123$. Effect of invitation by promoters to others to join them in acquiring property, and to become shareholders in corporation to be formed to purchase it. - When promoters are liable to account for secret profits, they are, as a rule, accountable only to the corporation. They may, however, under some circumstances, be accountable to the shareholders of the corporation to their separate use. It is a rule that when a person is concerned in a transaction in which he is acting for himself and his future partners, as an agent for the intended partnership, he is not permitted to take advantage of his situation, in order to obtain a personal benefit for himself; and that 
when he does obtain such a benefit it will be deemed that he holds it in trust for the partnership. ${ }^{1}$ On the principle of this rule, if promoters invite others to join with them on terms of equality in acquiring property with a view to the profit to be made from it by organizing to work it a corporation to be comprised of the associates, and the invitation is accepted, from that moment the associates are in a fiduciary relation, and one will not be allowed, while acting for himself and his associates, to make a profit in the common enterprise at the expense of the others. ${ }^{2}$ All profits thus obtained he must share with his associates. The cases in which shareholders of a corporation have maintained suits to recover to their individual use, profits from promoters, fall within this principle. In these cases, the standing of the plaintiffs was not that of mere shareholders of the corporation; it was that of associates with the promoters in a common enterprise, prior to the formation of the corporation, the incorporation being an incident of the enterprise.

$\S 124$. In Emery v. Parrott, ${ }^{3}$ - the facts were these: Archbold, who owned a coal mine, communicated to the defendants Head and Parrott his desire to sell the mine to a corporation to be formed to buy and work it, and he promised to give them a certain part of the price which he might thus obtain, if they would procure the formation of a corporation and the purchase of the mine by it. Parrott then induced the plaintiffs to join with him in acquiring the mine; and in behalf of himself and his associates he conducted various negotiations with

1 Fawcett v. Whitehouse, 1 Russ. \& Myl. 132 ; Colt v. Clapp, 127 Mass. 476.

2 Short v. Stevenson, 63 Penn. 95; Dole v. Wooldredge, 135 Mass. 140. And if he has himself purchased the property, his associates will be entitled to share in the benefit of his purchase.

8107 Mass. 96. 
Archbold, which resulted in a contract between Archbold and the associates to this effect, that the parties should form a corporation with a capital stock of $\$ 150,000$, half of which should be subscribed by Archbold, and half by the associates, and that the corporation should buy the mine for $\$ 75,000$, spend $\$ 70,000$ in improvements and machinery, and reserve the other $\$ 5,000$ for working capital. The provisions of this contract were substantially carried out; the corporation was formed; the mine was conreyed to it; certificates of its stock to the amount of $\$ 75,000$ were issued to Archbold in payment of the purchase price; and the associates furnished the required cash capital. Archbold then transferred 112. shares of his stock to Parrott, and 113 shares to Head, as a commission for their services. The plaintiffs, subsequently discovering the secret arrangement by which Parrott and Head received these shares, brought a bill in equity against them, which resulted in a decree to the effect that the plaintiffs were entitled to share in the stock received by the defendants from Archbold, and also in the dividends which the defendants had received on the stock.

$\S 125$. In Getty v. Devlin, ${ }^{1}$ - the following facts appeared: Bryan was the owner of leasehold interests in certain lands in the State of Ohio, which he had bouglit for about $\$ 15,000$ and paid for with his own moneys. Bryan and Arkenburg lield contracts for the purchase of other lands in Ohio for $\$ 15,000$. In this condition of things, the following scheme was entered into by Bryan, Arkenburg, Atwood, and Devilin, who were the defendants in the case. Devlin was to pay Bryan $\$ 7,650$ for one half the interest the latter then had in the property in question. An association was to be formed to which all the property

154 N. Y. $403 ; 70$ N. Y. 504. 
should be sold for $\$ 125,000$. Atwood was to receive onethird of the profit arising from the sale, and out of the residuc of the proceeds the original cost of the property was to be paid to Devlin, Arkenburg, and Bryan, and the remainder divided equally between them. In pursuance of this scheme the defendants then prepared the following paper : -

"We the undersigned, do hereby subscribe and agree to pay forthwith the amount set opposite our names for the purchase of property in Washington, Monroe, and Athens Counties, Ohio, as per memorandum annexed, being leasehold interest in 745 acres, and 207 acres in fee, at the sum of $\$ 125,000$, payments to be made to Daniel Devlin, Esq., at Broadway Bank, trustee for the purchasers, in whose name the title to property shall be taken, said property to be put into an association for development upon such terms as these subscribers may elect after this subscription is complete."

This paper was subscribed by the defendants for $\$ 5,000$ each, and it was then left with Atwood to procure subseriptions. The plaintiffs subscribed on the assurance that the property cost $\$ 125,000$. The interest of the defendants was concealed; they subscribed for shares to the amount of $\$ 60,000$ for the purpose of filling up the subscription; they gave away in decoy subscriptions about half of the amount to be subscribed. Subscriptions to the amount of $\$ 65,000$ were paid to Devlin, but the defendants paid nothing. After the subscriptions had been made, a meeting of the subscribers was held, and a corporation organized. Bryan, who then held the title to the lands, conveyed them to the corporation, reeeiving in payment certificates for all the shares of the eapital stock. These shares he transferred to Devlin in trust for all the subscribers of the subscription paper heretofore mentioned, and with the exception of a eertain number reserved for working eapital, they were distributed pro rata among the subscribers. The result of the enter- 
prise, shortly stated, was that the four defendants shared secret profits to the amount of $\$ 30,000$ in money, besides having as much stock as had those who paid their subscriptions in cash. On a bill in equity brought by the plaintiffs, it appearing that rescission was impossible, the real estate having been seized, and sold to satisfy a debt due from the company, it was held that the defendants must account for the profits which they had fraudulently appropriated to the exclusion of their associates, and that the plaintiffs were entitled to recover their pro rata share thereof.

$\S 126$. Rule as to joinder of plaintiffs in suit against promoters for an accounting. - When the misrepresentation made by the promoters as to the cost of the property has been made to the whole company, and not to the parties separately and individually, if an action at law can be maintained, it is not plain. whether the plaintiffs should join in the action, or whether each should bring an action to recover the damages he has sustained. But the injured parties may join in a bill in equity for an accounting. ${ }^{1}$

Article II.-Liability in Damages when in a Fiduciary Position toward Shareholders.

$\S 127$. When such relation exists between promoters and shareholders, former liable to latter in damages for breach of fiduciary duty to them.
§ 128. Brewster v. Hatch, $122 \mathrm{~N}$. Y. 349.

129. Teachout $v$. Van Hoesen, 76 Iowa, 113.

$\$ 127$. When fiduciary relation exists, promoters liable in damages to shareholders for breach of fiduciary duty to them. - While promoters stand in a fiduciary position

1 Dole v. Wooldredge, 135 Mass. 140. 
toward the corporation, they do not, as a rule, occupy that position toward the subscribers for shares. A breach of fiduciary duty by the promoters is ordinarily a breach of such duty to the corporation only; the injury occasioned thereby is to the corporation, - that is, to the shareholders collectively, and not individually, and the remedy is therefore worked out through the corporation. But, as we have already seen, the promoters may by their acts create a fiduciary relation between themselves and the subscribers for shares. In such event it is incumbent upon them to fully disclose all material facts within their knowledge touching the proposed enterprise. If they are to reccive profits or commissions, at the expense of the subscribers, it is their duty to disclose that fact. A failure to make proper disclosure which, if made, would have led the subscribers to decline to take shares, will enable the subscribers to recover their damages from the promoters. And this is also true when the subscribers have been induced to become such by misrepresentations as to cost or value, although misrepresentations of this nature may not be actionable when the parties are not in a fiduciary relation, but stand merely as vendor and vendee. 1

\$ 128. In Brewster v. Hatch, ${ }^{2}$ - the defendants associated themselves together to get up a corporation to acquire certain mining property wholly at the cost of such persons as they might induce to take and pay for shares of stock. Having procured an option for the purchase of the property in the name of Brown, one of their number, they sent out a prospectus and a subscription agreement. It was set out in this agreement that a corporation with a capital stock of $\$ 1,500,000$ was about to be organized for the purpose of acquiring title to the property referred to ; that all of the

1 Cheney v. Gleason, 125 Mass. 166.

2122 N. Y. 349. 
stock was to be issued to Brown in payment for the property; and that Hatch, one of the defendants, would, as trustee for the subscribers, receive moneys due on subscriptions, and hold the same to pay over to Brown upon the delivery of a deed of the property in question, from him to the corporation, and the transfer by him to the subscribers of the number of shares of stock respectirely subseribed for by them. By the terms of the agreement, the subscribers thereto covenanted with Brown that they would accept the shares to be transferred to them by Brown, and that they would make payment for the same to Hatch, at the rate of four dollars per share on the trust stated. Subseriptions having been received from the plaintiffs and others for about sixty-one thousand shares at the price agreed upon, the defendants proceeded to organize the corporation, naming themselves as trustees for the first year. Brown thereupon completed the purchase of the property in his own name, and immediately conveyed it to the corporation; all the shares of stock were issued to him, and he transferred to the subscribers the number of shares for which they had respectively subseribed. The money which the subscribers had paid to Hatch was then applied in payment of a loan which the defendants had obtained, in order to enable Brown to pay the purchase price of the property, when it was conreyed to him. After paying the cost of the purchase and other expenses, the defendants had remaining on hand 58,235 shares of stock for which they had paid nothing, and which they appropriated to their own use. When the plaintiffs received and paid for their stock, they had no knowledge that the defendants were to have shares without paying for them. In an action by the plaintiffs to recover damages, it was held that they were entitled to recover, on the ground that the relation between the parties was not that of vendors and rendees simply, but was of a fiduciary 
nature, binding the defendants to the exercise of good faith and imposing on them the duty of disclosure. The invitation extended by the defendants to the plaintiffs, it will be observed, was not in behalf of the projected corporation to enter into a contract with the corporation, when formed, to take from it shares of its capital stock, but was in effect to become associated with the defendants on terms of equality in a common enterprise, of which incorporation was to be merely an incident. ${ }^{1}$

$\S 129$. In Teachout v. Van Hoesen, ${ }^{2}-$ it appeared that Teachout and Branson had purchased certain property used in carrying on the ice business for the sum of $\$ 14,000$, of which $\$ 5,000$ was paid in cash, and the balance was to be paid by notes secured by a mortgage. Shortly afterward, Teachout invited Van Hoesen to join them in a partnership to acquire the property and carry on the business; he told Van Hoesen that he could have an interest at cost, and that the property had cost $\$ 20,000$, of which $\$ 11,000$ had been paid in cash, the deferred payment of $\$ 9,000$ to be secured by a mortgage on the property. Van Hoesen agreed to invest $\$ 1,500$, on the terms stated, with the privilege of increasing his interest to one-third, making the interest of each of the three parties equal. Subsequently, Teachout proposed to Van Hoesen that the parties in interest should form a corporation instead of a partnership, the property to be turned in to the corporation on the same basis that it was to have been turned in to the partnership, that is, at cost. The corporation was organized with a capital stock divided into 300 shares of the par value of $\$ 100$ each. One hundred shares were issued to Branson and the same number

1 See also Getty v. Devlin, supra, where the defendants were compelled to share secret profits with their associates, but the Court said that an action for damages might have been maintained.

276 Iowa, 113. 
to Teachout and the property was conveyed by them to the corporation which bound itself to meet the deferred payment of $\$ 9,000$. Fifteen shares were issued to Van Hocsen on payment by him of $\$ 1,500$ in money. Van Hoesen subsequently, in accordance with his option by which he had the right to increase his subscription so that he might have an equal interest with Branson and Teachout, paid in the further sum of $\$ 4,000$. He was induced to pay in the sum of $\$ 5,500$ in all, in the belief that Branson and Teachout had each paid out that sum in the original purchase of the property in question, when, in truth and fact, they had paid but $\$ 5,000$ in the aggregate. The result was that Branson and Teachout each obtained a one-third interest in the corporation by the payment of $\$ 2,500$ each, and Van Hoesen paid for his one-third interest $\$ 5,500$, although the invitation extended to and accepted by him was to join his associates in the enterprise on terms of equality. It was held that he was entitled to recover damages from Teachout. The Court said: "It is to be remembered that the fraud complained of had its inception before the corporation was organized. It was a personal transaction between individuals. In making the representations complained of, the plaintiff was not acting as the agent of the corporation, but for the promotion of his own interest, and it seems that the reparation for the wrong done should be made by the wrong-doer to the person upon whom the injury was inflicted. ${ }^{1}$

1 See also Paddock v. Fletcher, 42 Vt. 389 ; Cheney v. Gleason, 125 Mass. 166. 
Article III. - Promoters' Liability in Damages when not in a Fiduciary Position toward Shareholders.

$\S 130$. Promoters ordinarily not in fiduciary position toward subscribers for shares.

131. When action will lie in favor of subscribers against promoters for misrepresentations.

132. Misrepresentation must be assertion of fact.

133. Mere commendatory expressions privileged.

134. Representation as to value in exceptional circumstances not privileged.

135. Representation as to price paid by third persons for shares or as to cost of company's property not privileged.

136. Commendatory expressions in prospectuses.

137. Expressions of opinion, although untrue, not actionable.

138. Representations as to the law.

139. Representation must be of a material fact.

140. Promoters as a rule not liable to purchasers of shares for misrepresentation in prospectus addressed by them to prospective subscribers for shares.

141. But connection between promoters issuing prospectus and persons purchasing shares in reliance upon it may be shown.

142. Andrews $v$. Mockford, 1 Q. B. (1896), 372.

143. Representation must be frandulent as well as false. Facts to be proved to establish fraud.

144. False representation made as of one's own knowledge deemed fraudulent.

145. Absence of reasonable grounds for belief in representation evidence that it is fraudulent.
$\S 146$. Effect of subsequent discovery by one who lias made representation that it is untrue.

147. Fraud may be inferred from concealment as distinguished from non-disclosure of material facts.

148. Circumstances under which non-disclosure of facts may make facts stated false.

149. Omission of facts from prospectus not ground for action of deceit, unless it makes facts stated false.

150. Peek v. Gurney, L. R., $6 \mathrm{H}$. L. 377.

151. Statement of portion of truth with suggestions and inferences rendered credible only by suppression of other portions of truth.

152. Rules as to misrepresentation and non-disclosure not the same in actions ex-delicto as in suits for equitable relief.

153. No legislation in this country requiring promoters'agreements to be disclosed in prospectuses.

154. English statute on subject.

155. Right of subscriber to rely on representations addressed to him.

156. Liability of promoters on sale of shares issued to them at discount or in payment for property at overvaluation.

157. Liability of promoters for misrepresentations made by co-promoters.

158. Conflicting views as to measure of damages.

159. Rule in Massacliusetts and other jurisdictions.

160. Rule in New Jersey.

161. Rule laid down in England and by Supreme Court of United States. 
$\S 130$. Promoters ordinarily not in fiduciary position toward subscribers for shares. - Promoters do not put themselves in a fiduciary position toward intending subscribers for shares by the mere act of issuing prospectuses, or inviting or negotiating for subscriptions, in behalf of the projected corporation. Their position in this respect does not differ from that of the parties in the ordinary case of an advertisement of goods or chattels for sale. Exceptional facts must appear to establish a fiduciary relation. Ordinarily, then, this relation does not subsist between promoters and subscribers for shares. ${ }^{1}$ This brings us to a consideration of the subject of the liability of promoters, ex delicto, to subscribers for shares, when there is no relation of trust and confidence between the parties.

$\S 131$. When action will lie in favor of subscribers against promoters for misrepresentations. - An action for damages will lie against promoters of a corporation in favor of persons who have been induced by misrepresentations made by the promoters to subscribe for shares of the capital stock of the corporation, provided the misrepresentation complained of is an assertion of a material fact, is fraudulent, is actually or constructively addressed to the subscriber, and the subscriber has been deceived and damnified thereby.

$\S 132$. Misrepresentation must be assertion of fact. - The misrepresentation must be an assertion of a fact as distinguished from an expression of opinion. If it is stated

1 Derry v. Peek, 14 App. Cas. 337; Peek v. Gurney, L. R. 6 H. L. 377; Arkwright v. Newbold, 17 Ch. D. 301; Dwight on Law of Persons and Personal Property, 393; Coil v. Pittshurgh Female College, 40 Penn. 439. "It is not believed that the American adjudications require in such contracts any greater degree of good faith than is exacted of parties in regard to other contracts." Lawson on Contracts, Sect. 220. "In all contracts of buying and selling, the maxim is, Caveat emptor; and contracts to take shares are apparently governed rather by this principle than by any other." Lindley on Law of Companies, 5th ed. 70 . 
that a gold mine has produced so much gold, that is a representation of a fact; if it is stated that it will yield such an amount of gold, that is an expression of an opinion. A representation of one's existing intention is a statement of a fact which may be material. ${ }^{1}$ Thus, in Edgington v. Fitzmaurice, ${ }^{2}$ the directors of a corporation issued a prospectus inviting subscriptions for shares, and stating that their intention was to apply the moneys received in improving the property of the corporation, and in extending its business. In fact, the moneys were wanted to meet pressing obligations. In an action for deceit brought against the directors by a subscriber, it was held that the misstatement of intention was a misstatement of an existing fact. "The state of a man's mind," said Bowen, L. J., " is as much a fact as the state of his digestion." Yet if an existing intention is truly stated, its character is not altered by a subsequent departure from it. An intention may be changed without responsibility, unless there has been a contract not to change it. ${ }^{3}$ A promise is a statement as to one's intention. If a person makes a promise, not intending at the time to fulfil it, it is a misrepresentation of an existing fact. 4

§ 133. Mere commendatory expressions privileged.-Praise of what one has to sell, by false statements as to value, quality, or characteristics, is not ordinarily ground for an action for deceit. ${ }^{5}$ Statements of this nature afford to the

1 Bryant v. Ocean Ins. Co., 22 Pick. at p. $203 . \quad 229$ Ch. D. 459.

${ }^{8}$ Gray v. Suspension Car Truck Mfg. Co., 127 Ill. 187; Long v. Woodman, 58 Me. 49 ; Jordan v. Money, 5 H. L. Cas. 185.

4 Goodwin v. Home, 60 N. H. 485; 1 Bigelow on Fraud, 484. Contra: Dawe v. Morris, 149 Mass. 188.

5 Dimmock v. Hallett, L. R. 2 Ch. 21; Gordon v. Parmelee, 2 Allen, 212 ; Veazey v. Doten, 3 Allen, 380; Deming v. Darling, 148 Mass. 504; Ellis v. Andrews, 56 N. Y. 83; Holbrook v. Connor, 60 Me. 578; Suessenguth v. Bingenheimer, 40 Wisc. 370; Anderson v. Hill, 12 Smedes \& M. 679 ; Vawter v. Ohio, etc., R. R. Co., 14 Ind. 
person to whom they are addressed no excuse for omitting to examine, or to make an investigation as to the thing commended, although it is at a distance, and is not seen by him $;{ }^{1}$ for " it has always been understood the world over that such statements are to be distrusted." 2 "They are such as the law, in deference to the universal habit and practice of mankind, permits men to make in commending property offered for sale, and as to which the buyer (unless there be peculiar relations of trust and confidence between him and the seller) must rely upon his own judgment." 3 They are looked upon as expressions of opinion. Thus, it has been said of a statement as to the value of land, that the persons to whom the statement was addressed must hare known that it was " a mere matter of opinion upon a subject upon which absolute knowledge could not be expected. In most cases it would be impossible to prove that one was knowingly and wilfully false in giving such an opinion, and that is one of the reasons for refusing to enter upon inquiries of this kind. . . . It would be unjust to convict one of fraud on a mere expression of opinion, upon any evidence which can ordinarily be introduced, and for that reason, as well as because common prudence forbids implicit reliance upon such expressions, we have the general rule that false statements of opinion are not actionable." 4

$\$ 134$. Representation as to value in exceptional circumstances not privileged. - Still, a representation of value may

174; Schramm v. O'Connor, 98 Ill. 539; Wise v. Fuller, 29 N. J. Eq. 262 ; Shanks v. Whitney, 66 Vt. 405 ; Union Nat. Bank v. Hunt, 76 Mo. 439 ; Doran v. Eaton, 40 Minn. 35.

1 Parker $\nabla$. Moulton, 114 Mass. 99.

2 Metcalf, J., in Brown v. Castles, 11 Cush. at p. 350.

${ }^{3}$ Gilfillan, Ch. J., in Doran v. Eaton, 40 Minn. 35.

4 Knowlton, J., in Nash v. Minnesota Title Ins. \& Trust Co., 159 Mass. at p. 441. 
go beyond opinion into fact. ${ }^{1}$ Again, if a person making a representation of the nature stated falsely and fraudulently holds himself out and is relied upon as an expert, ${ }^{2}$ or fraudulently induces the person with whom he is dealing to forbear inquiries which he otherwise would have made, ${ }^{3}$ or if the representation relates to a matter peculiarly within the knowledge of the person making it, ${ }^{4}$ then there is no exemption from liability on the ground that the representation is in the nature of "dealers' talk," or an expression of opinion. There is some conflict of authority on the question whether a statement as to cost is to be treated as "dealers' talk." 5

$\S 135$. Representation as to price paid by third persons for shares, or as to cost of company's property, not privileged. But it is obvious that a representation to an intended subscriber as to the price paid by other subscribers for shares in a corporation, ${ }^{6}$ or as to the price paid by the corporation for property, is not privileged. 'The one is a representation in relation to the amount of the corporation's capital; the other a representation as to the application of its capital. ${ }^{7}$

$\S 136$. Commendatory expressions in prospectuses. - The rule stated as to commendatory expressions applies to

1 Bishop on Non-Contract Law, Sect. 327 ; King v. Sioux City Loan \& Inv. Co., 76 Iowa, 11.

2 Kost v. Bender, 25 Mich. 515.

8 Parker v. Moulton, 114 Mass. 99.

4 Bloomer v. Gray, 10 Ind.`App. 326 ; Stewart v. Stearns, 63 N. H. 99.

5 Treated as trade or dealers' talk, - Medbury $\mathrm{v}$. Watson, 6 Met. 246; Manning v. Albee, 11 Allen, 520; Holbrook v. Connor, 60 Me. 578. Contra, - Van Epps v. Harrison, 5 Hill, 63; Ives v. Carter, 24 Conn. 392 ; McFadden v. Robinson, 35 Ind. 24; Somers v. Richards, 46 Vt. 170; McAleer v. Horsey, 35 Md. 439 ; Fairchild v. McMahon, 132 N. Y. 290.

${ }^{6}$ Coolidge v. Goddard, 77 Me. 578; Caswell v. Hunton, 87 Me. 277 ; Kilyore v. Bruce, 166 Mass. 136.

7 Lindsay Petroleum Co. v. Hurd, L. R. 5 P. C. 221; Clarke v. Dickson, 6 C. B. (N. s.) 453. 
statements which are but expressions of hope, expectation, or confidence, and it is applicable to prospectuses issued by promoters. "I consider that in such a document as the prospectus of a company," said Turner, L. J., "allowance must be made for some latitude of statement." 1 Lord Romilly said: "Anybody who looks at a prospectus understands that the thing is colored in this sense, that everything is put forward in the most favorable view it can be." 2 And Lord Chelmsford said : "Some allowance must always be made for the sanguine expectations of the promoters of the adventure, and no prudent man will accept the prospects which are always held out by the originators of any new scheme, without considerable abatement. But although on its introduction to the public, some high coloring and even exaggeration in the description of the advantages which are likely to be enjoyed by the subscribers to an undertaking may be expected, yet no misstatement or concealment ought to be permitted." 3 It must be borne in mind, however, that " you may use language in such a way as, although in the form of hope and expectation, it may become a representation as to existing facts, and if it is so, and it is brought to your knowledge that these facts are false, it is a fraud." 4 If the language used in a prospectus is ambiguous, the burden is on the complaining subscriber to prove that he understood it in the sense in which it was untrue. If the defendants, said Lord Blackburn in Smith

1 Central Ry. Co. of Venezuela v. Kisch, 34 L. J. Ch. at p. 552.

2 Denton v. MacNeil, 2 Eq. 355.

8 Central Ry. Company of Venezuela v. Kisch, L. R. 2 H. L. 113.

"“'We agreed, howerer,' Pen said, laughing, ' that because the prospectus was rather declamatory and poetical, and the giant was painted on the show-board rather larger than the original, who was inside the caravan, we need not be too scrupulous about the trifling inaccuracy." " (Thackeray's Pendennis.)

4 Lord Halsbury in Aaron's Reefs v. Twiss, A. C. (1896) 273 . For the facts in this case, see Sect. 151. 
v. Chadwick, ${ }^{2}$ with intent to lead the plaintiff to act upon it, "put forth a statement which they know may have two meanings, one of which is false to their knowledge, and thereby the plaintiff putting that meaning upon it is misled, I do not think they can escape by saying he ought to have put the other. If they palter with him in a double sense, it may be that they lie like truth, but I think they lie, and it is a fraud. Indeed, as a question of casuistry, I am inclined to think the fraud is aggravated by a shabby attempt to get the benefit of the fraud, without incurring the responsibility."

$\S 137$. Expressions of opinion although untrue, not actionable. - A statement in the nature of an expression of opinion, although untrue, will not, as a rule, ground an action for deceit. The person to whom it is addressed is bound to exercise his own judgment, and it is his own fault if he allows himself to be misled by the opinion of another. The following untrue representations, held to be of opinion and not of fact, will serve to illustrate the rule: That the rents of certain real estate to be acquired by a corporation would pay six per cent on the capital stock of the corporation the first year. $^{2}$ That the probable expense of certain improvements would be a sum stated. ${ }^{3}$ That a specified tract of land contained large deposits of oil, it being known to both parties that the land had not been tested ${ }^{4}$ it would have been otherwise if the land had been tested to the knowledge of the vendor. ${ }^{5}$ While statements as to value are, as has been pointed out, ordinarily regarded as expressions of opinion,

1 Smith v. Chadwick, 9 App. Cas. 187. See Yeates v. Prior, 6 Eng. (Ark.) 58.

2 Hughes v. Antietam Mfg. Co., 34 Md. 316.

2 Crossman v. Penrose Ferry Bridge Co., 26 Penn. 69.

4 Holbrook v. Connor, 60 Me. 578.

5 Fisher v. Worrall, 5 W. \& S. 483; Higgins v. Crouse, 147 N. Y. 411. 
it is otherwise in the case of statements of facts which go to make up value, - as, for example, statements in relation to the pecuniary condition of a corporation, made to induce subscriptions to its stock. ${ }^{1}$

$\S 138$. Representations as to the law. $-A$ representation concerning the law is taken to be the expression of an opinion, and not the statement of a fact. The nature of such a representation has been explained with great clearness as follows :-

"A representation in law is this: When you state the facts, and state a conclusion of law, so as to distinguish between facts and law, a man who knows the facts is taken to know the law; but when you state that as a fact which no doubt involves, as most facts do, a conclusion of law, that is still a statement of fact and not a statement of law. Suppose a man is asked by a tradesman whether he can give credit to a lady, and the answer is 'You may; she is a single woman of large fortune.' It turns out that the man who gave the answer know that the lady had gone through a ceremony of marriage with a man who was believed to be a married man, and that she had been advised that that marriage ceremony was null and void, though it had not been declared so by any court, and it afterwards turned out that they were all mistaken, that the first marriage of the man was void, so that the lady was married. He does not tell the tradesman all these facts, but states that she is single. That is a statement of fact. If he had told him the whole story and all the facts, and said, 'Now you see the lady is single,' that would have been a misrepresentation of law." 2

1 Bigelow's Elements of Law of Torts, 15; Campbell v. Fleming, 1 Adol. \& El. 40; Bedford v. Bagshaw, 4 Hurl. \& N. 538; Bradley v. Poole, 98 Mass. 169.

2 Jessel, M. R., in Eaglesfield v. Londonderry, 4 Ch. D. 693; Upton v. Tribilock, 91 U. S. 45; Jaggar v. Winslow, 30 Minn. 263; 
But a misrepresentation as to the law of a foreign country is a misstatement of fact. ${ }^{1}$

$\$ 139$. Representation must be of a material fact. - The representation must be of a material fact. ${ }^{2}$ It has been said that no better rule ean be given for deciding this question than this: "If the fraud be such that, had it not been practised, the contract could not have been made or the transaction completed, then it is material to it; but if it be shown or made probable that the same thing would have been done in the same way if the fraud had not been practised, it cannot be deemed material." 3 The materiality of the representation is a question of law for the Court. ${ }^{4}$

Thompson v. Phœnix Insurance Co., 75 Me. 55; Etna Insurance Co. v. Reed, 33 Ohio St. 293; People v. Central Pacific R. R. Co., 27 Cal. 655; Fish v. Cleland, 33 Ill. 238; Davis v. Betz, 66 Ala. 206. It is said in Pollock on Contracts, 522, that the rule "probably does not apply to a deliberately fraudulent misstatement of the law. The circumstances and the position of the parties may well be such as to make it not imprudent or unreasonable for the person to whom the statement was made to rely on the knowledge of the person making it; and it would certainly work injustice if it were held necessary to apply to such a case the maxim that every one is presumed to know the law." On this point the author cites Hirschfield v. London, Brighton \& South Coast Ry. Co., 2 Q. B. D. 1 ; Bowen, L. J., in West London Comnercial Bank v. Kitson, 13 Q. B. D. at p. 363 . See also Burns v. Lane, 138 Mass. 350; Moreland v. Atchison, 19 Tex. 303; Stumpf v. Stumpf, 7 Mo. App. 272 ; Berry v. Whitney, 40 Mich. 65.

1 Bethell v. Bethell, 92 Ind. 318; Haven v. Foster, 9 Pick. 112; Windram v. French, 151 Mass. 547 ; Upton v. Englehart, 3 Dill. 496. See Payson v. Withers, 5 Biss. (U. S.) 269, holding that a subscriber for shares of stock of a corporation of a foreign State is bound to know the law of that State.

${ }^{2}$ Hedden v. Griffin, 136 Mass. 229 ; Hall v. Johnson, 41 Mich. 286; Schwabocker v. Biddle, 99 IIl. 343 ; Coles v. Kennedy, 81 Iowa, 360 ; Karberg's Case, 1892, 3 Ch. 1.

8 MeAleer v. Horsey, $35 \mathrm{Md}$. at p. 452.

4 Penn. Mut. Life Ins. Co. v. Crane, 134 Mass. 56 ; Caswell v. Hunton, 87 Me. 277; 1 Bigelow on Fraud, 139. Contra, - McAleer v. Horsey, $35 \mathrm{Md}$. 452. See Moore v. The Explosives Co., $56 \mathrm{~L}$. J. (Q. B.) 285. 
A representation may be of such a nature as to be susceptible of interpretation either as an expression of opinion or as a statement of a fact. It is then for the jury to determine the actual intent. ${ }^{1}$

$\S 140$. Promoters, as a rule, not liable to purchasers of shares for misrepresentation contained in a prospectus addressed by them to prospective subscribers for shares. - The representation must be made with intent that it shall be acted on by the injured party in the manner that occasions the injury, and the injury must be the immediate and not the remote consequence of the representation. ${ }^{2}$ When promoters issue a prospectus in behalf of the corporation, inviting subscriptions for shares, the prospectus ordinarily is addressed to prospective subscribers and to induce subscriptions only. It is not an invitation to the public ultimately to become holders of shares. Accordingly, in such case those only who have been induced by misrepresentations contained in the prospectus to become subscribers can have a remedy against the promoters. The purchaser of shares in the market, on the faith of a fraudulent prospectus, which he has not received from those answerable for it, and which is issued, not for the purpose of inducing dealing in the stock, but solely to procure subscriptions, cannot by action upon the prospectus so connect limself with those responsible for it as to render them liable to him, as if it had been addressed personally to him. ${ }^{3}$

1 Morse v. Shaw, 124 Mass. 59; Teague v. Irwin, 127 Mass. 217; Warner v. Benjamin, 89 Wisc. 290. But compare 1 Bigelow on Fraud, 141, 142; Edgington v. Fitzmaurice, 29 Ch. D. 459.

2 Lord Hatherly in Barry v. Croskey, 2 J. \& H. 21; Denton $\nabla$. Great Northern Ry. Co., 5 E. \& B. 860.

8 Peek v. Gurney, L. R. 6 H. L. 377 ; Nash v. Minnesota Title Insurance \& Trust Co., 159 Mass. at p. 442.

Judge Thompson in his Commentaries on the Law of Corporations, Sects. 1471, 1472, criticises the doctrine of Peek v. Gurney, and char- 


\section{$\$ 141$. But connection between promoters issuing prospec-} tus and persons purchasing shares in reliance upon it may be shown. - Nevertheless, a prospectus may be issued by promoters with such intent and in such manner as to establish a connection between them and purchasers of shares in

acterizes it as destitute of reason and opposed to justice and business morality. "Under this rule," he says, "the directors might get the fruits of their fraud, and escape all liability by the simple device of colluding with certain persons to become the purchasers of the shares in the first instance, and to unload them upon the innocent public before the discovery of the fraud." It is plain that in such a case the prospectus would have been fraudulently issued to lead the public to purchase shares from the original subscribers. There would be a clear connection between the persons issuing it, and persons led by it to purchase shares. The transaction would not be within the rule laid down in Peek v. Gurney. The learned author cites four cases to show that the rule in this country is contrary to that announced in Peek v. Gurney, but they are all distinguishable. (1) Morgan v. Skiddy, 62 N. Y. 319. This is not a case in which the prospectus was issued to invite subscriptions. All the stock of the company had been issued in payment for a mine in which the promoters were interested, and the prospectus was issued for the purpose of creating a market for the stock, and luring the public to buy it. (2) Cross v. Sackett, 2 Bosw. 617 , presents facts of the same nature, and proceeds on the same ground as Morgan v. Skiddy. The Court said : "We admit that it cannot be law that a person who deceives $A$. by some instrument, and by it intends to deceive only him, can be made liable to every person who is injured from dealing with $A$., by being misled by the instrument which deceived $A$., and was made to deceive him alone." (3) Caseaux v. Mali, 25 Barb. 578. This is a decision on a demurrer to a declaration which alleged that the plaintiff purchased shares of stock of a company of which the defendants were directors; that certain false representations were made by the defendants "for the purpose of inducing parties, particularly the plaintiff, to purchase said stock; and that the plaintiff was thereby influenced in making said purchase." (4) Bartholemew v. Bentley, 15 Ohio, 659. This is a decision on a demurrer to a declaration which alleged that the defend. ants, conspiring to cheat and defraud the public, and falsely pretending to have authority as a banking corporation, and that such corporation had a suitable capital, issued and put into circulation notes and bills of the pretended bank to a large amount. 
the market, claiming to have been deceived by misrepresentations in the prospectus. Thus it may be delivered by the promoters to a person for the express purpose of inducing him to purchase shares, or it may be addressed to the public with a view to create a market for the shares, and thus, perhaps, to enable the promoters to unload their own shares, as, for example, when it is circulated after all the shares have been allotted. Under such conditions persons who have been induced to purchase shares by false and fraudulent statements in the prospectus, have their romedy against the promoters. 1

$\S 142$. In Andrews v. Mocleford, ${ }^{2}$ - the jury found that the defendants had conspired to defraud the public by promoting a sham mining company; that they had authorized the issue of a fraudulent prospectus of the company, in order to induce the public to buy shares in the market, as well as to apply to the company for shares ; that they had subsequently, for the purpose of creating fictitious prices for shares, and to induce the public to buy at such fictitious prices, caused to be published in the newspapers a false telegram as to the discovery of ore in the company's mine; and that on the strength of this telegram and on the faith of the prospectus, the plaintiff had bought shares in the market, and had suffered loss thereby. On these findings, it was held that the plaintiff was entitled to judgment. The judgment was sustained in the Court of Appeal, the Court saying, through Lord Esher, that there was evidence upon which the jury might well come to the conclusion that the defendants, when they sent out the prospectus, did not issue it merely with the object of inviting people to subscribe to the proposed company, but that they issued it having in

1 Scott v. Dixon, 29 L. J. Ex. 62 n.; Gerhard v. Bates, 2 El. \& Bl. 476; Morgan v. Skiddy, 62 N. Y. 319 ; Cross v. Sackett, 2 Bosw. 617.

21 Q. B. (1896), 372. 
their minds the intention of using it afterward to carry out the fraud, and supporting the prospectus afterward by other means; that they did subsequently resort to other means to carry out that original intention; that there had been one continuous frand, beginning with the prospectus and culminating in the publication of the telegram, practised by the defendants upon the plaintiff to induce him to purchase shares in the company in the market; and that the plaintiff was damaged in consequence of having so purchased shares in the market.

$\$ 143$. Representation must be fraudulent as well as false. Facts to be proved to establish fraud. - The representation must be not only false but fraudulent. Promoters who issue a prospectus do not impliedly warrant the truth of the statements contained in it. ${ }^{1}$ As a rule they are not subject to a duty, such as the law recognizes, to be careful in making representations to intending subscribers for shares. The doctrine that negligent misrepresentation affords a cause of action for damages is confined to cases in which there is a duty imposed by law to be careful. ${ }^{2}$ In Derry v. Peek, ${ }^{3}$ a case of misrepresentation in a prospectus, the House of Lords considered that the circumstances raised no such duty. If the misrepresentation was made with intent honestly to tell the truth, and not recklessly, even though there was negligence, ignorance, or stupidity on the part of the person making it, an action for damages cannot be sustained. ${ }^{4}$ In Derry v. Peek,

1 Lindley, L. J., in Low v. Bouviere (1891), 3 Ch. at p. 101.

2 Bowen, L. J., in Low จ. Bouviere, 3 Ch. (1891), at p. 105 Kountze จ. Kennedy, 147 N. Y. 124.

814 App. Cas. 337.

4 But in Hubbard v. Weare, 79 Iowa, 678, it was held that the officers of a corporation who invite the public to take shares on the 
Lord Herschell said: "I think the authorities establish the following propositions : First, in order to sustain your action of deceit, there must be proof of fraud, and nothing short of that will suffice. Secondly, fraud is proved when it is shown that a false representation has been made, (1) knowingly, or (2) without belief in its truth, or (3) recklessly, careless whether it be true or false, Although I have treated the second and third as distinct cases, I think the third is but an instance of the second, for one who makes a statement under such circumstances can have no real belief in the truth of what he states. To prevent a false statemeut being fraudulent, there must, I think, always be an honest belief in its truth. And this probably covers the whole ground, for one who knowingly alleges that which is false has obviously no such honest belief. Thirdly, if fraud be proved, the motive of the person guilty of it is immaterial. It matters not that there was no intention to cheat or injure the person' to whom the statement was made." 1

faith of their representations, will be presumed to have known that which it was their duty to know ; that it is their duty to use reasonable diligence to ascertain the truth of the facts which they state; and that they will be presumed to possess the knowledge which the exercise of such diligence would have brought them. "Outside investors," it was said, "can know but little of the affairs of the corporation, while its officers may and should know them fully."

1 See also Glassier v. Rolls, 42 Ch. D. 436; Angus v. Clifford, (1891), 2 Ch. 449; Le Lievre v. Gould (1893), 1 Q. B. 491 . Following upon and in consequence of the decision in Derry v. Peek, the Directors' Liability Act, 1890, was passed in England. It gives a person who has been led by a false statement in a prospectus to subscribe for shares in a company, a right to recover damages for his loss from the promoters or directors, unless they can prove that they had reasonable ground to believe the statement and continued to believe it until the shares were allotted, or that the statement was a fair account of the report of an expert or a correct representation of an oficial document. 
$\$ 144$. False representations made as of one's own knowledge deemed fraudulent. - The weight of authority in this country supports the proposition thus stated by Lord Herschell.1 But it may be added that fraud is proved when it is shown that a false representation has been made "as of the party's own knowledge, provided the thing stated is not merely a matter of opinion, estimate, or judgment, but is susceptible of actual knowledge. The fraud consists in stating that the party knows the thing to exist, when he does not know it to exist; and if he does not know it to exist, he must ordinarily be deemed to know that he does not. Forgetfulness of its existence after a former knowledge, or a mere belief of its existence, will not warrant or excuse a statement of actual knowledge." 2

1 Nash v. Minnesota Title Insurance \&. Trust Co., 163 Mass. 578; Id. 159 Mass. 437 ; Page v. Parker, 40 N. H. 47 ; Hammett $\nabla$. Emerson, 27 Me. 308; Marsh v. Falker, 40 N. Y. 562 ; Chester v. Comstock, 40 N. Y. 575 ; Kountze v. Kennedy, 147 N. Y. 124; Cowley v. Smyth, 46 N. J. L. 388; Holdom v. Ayer, 110 Ill. 448; Avery v. Chapman, 62 Iowa, 144 ; Sollund v. Johnson, 27 Minn. 455; Erie City Iron Works v. Barber, 106 Penn. 125̃ Crown v. Brown, 30 Vt. 707 ; Bartholemew v. Bushnell, 20 Conn. 271; Rawson v. Harzan, 48 Iowa, 269; Union Pacific Ry. Co. v. Barnes, 64 Fed. Rep. 80; Farmers' Stock Breeding Association v. Scott, 53 Kan. 534; Williams v. McFadden, 23 Fla. 143; Jackson v. Stockbridge, 29 Tex. 394 ; Robertson v. Parks, 76 Md. 118; Taylor v. Leith, 26 Ohio St. 428; Bishop on Contracts, Sect. 662. Contra. - Bird v. Kleiner, 41 Wisc. 134 ; Totten v. Burhans, 91 Mich. 495 ; Montreal River Lumber Co. v. Milhils, 80 Wisc. 540.

2 Allen, J., in Chatham Furnace Co. v. Moffat, 147 Mass. 404; Kountze v. Kennedy, 147 N. Y. 124; Stone v. Denny, 4 Met. 151; Cooper v. Schlesinger, 111 U. S. 148; Bower v. Fenn, 90 Penn. 359; Graham v. Nowlin, 54 Ind. 389 ; Hammett v. Emerson, 27 Me. 308; Ford v. McComb, 12 Bush (Ky.), 723; Mitchell v. Zimmerman, 4 Tex. 75; Cabot v. Chester, 42 Vt. 121 ; Indianapolis, Peru, \& Chicago Ry. Co. v. Tyng, 63 N. Y. 653 ; Smith v. Newton, 59 Ga. 113 ; Caldwell v. Henry, 76 Mo. 254; Kilpatrick v. Reeves, 121 Ind. 280; Humphrey v. Merriam, 32 Minn. 197. 
$\S 145$. Absence of reasonable grounds for belief in representation evidence that it was fraudulently made. - While a statement made with an honest belief in its truth cannot furnish ground for an action of deceit, the absence of reasonable grounds for belief is evidence of the nonexistence of such belief. And it has been observed that " if a man neglects means of information which were at hand, and which would have corrected his belief in the matter, he lays himself open to the suggestion that he took care not to acquaint himself with inconvenient facts." 1

$\S 146$. Effect of subsequent discovery by one who has made representation that it is untrue. - When a person who has made a representation, honestly believing it to be true, subsequently and before the other party has acted upon it, discovers that it is not true, it seems that he will be deemed to have made a fraudulent representation, if, having the means of communicating the truth to the other party, he omits to do so, and suffers him to continue in error and to act on the belief that no mistake has been made. The offer to contract being treated as a continuing offer till revocation or acceptance, the representation must, it is thought, likewise be taken to be continuously made until it is acted upon or withdrawn. ${ }^{2}$

$\S 147$. Fraud may be inferred from concealment as distinguished from non-disclosure of material facts. - A fraudulent misrepresentation may be implied from successful efforts to conceal material facts, as, for example, by interposing obstacles to their discovery, or by diverting attention from them. ${ }^{3}$

1 Anson on Contracts, 169.

2 Webb's Pollock on Torts, 366 ; Reynell v. Sprye, 1 D. M. G. 660 , 709. See Arkwright v. Newbold, 17 Ch. D. at pp. $325,329$.

s Matthews v. Bliss, 22 Pick. 48; Kenner v. Harding, 85 Ill. 265; Croyle v. Moses, 90 Penn. 250; Roseman v. Canovan, 43 Cal. 110 ; T'yler จ. Savage, 143 U. S. 79. 
$\S 148$. Circumstances under which non-disclosure of facts may make facts stated false. - A fraudulent misrepresentation may under certain conditions arise from the intentional non-diselosure of facts. In the language of Lord Cairns, there may be " such a partial and fragmentary statement of fact as the withholding of that which is not stated makes that which is stated absolutely false." 1 Commenting on this, Cotton, L. J., said: "Of course I adopt what has been said by Lord Cairns, that the omission of something in a prospectus or other document may make the statement contained in it false, as, for instance, if it contained the statement of a covenant, and omitted to state the fact that the corenant had been released." In the same case, James, L. J., said: "Suppose you state a thing partially, you may make a false statement as mueh as if you had misstated it altogether. Every word may be true, but if you leave out something which qualifies it, you may make a false statement. For instance, if pretending to set out the report of a surveyor, you set out two passages in his report, and leave out a third passage which qualifies them, that is an actual misstatement." 2

$\S 149$. Omission of facts from prospectus not ground for action of deceit, unless it makes facts stated false. - But in the case of representations made by promoters through a prospectus or otherwise, mere omission is not, if it does not make the substantive statements false, a sufficient ground for maintaining an action of deceit. This was expressly adjudged by the Court of Appeal in Arkwright v. Newbold. ${ }^{3}$ At the trial in this case, Fry, J., said: "It appears to me

1 Peek v. Gurney, L. R. 6 H. L. 377.

2 Arkwright v. Newbold, 17 Ch. D. 320 ; see Miller v. Barber, 66 N. Y. 558; Coles v. Kennedy, 81 Iowa, 360; Oakes v. Tourquand, L. R. 2 H. L. 344 ; Central Ry. Co. of Venezuela v. Kisch, L. R. 2 H. L. 113. 817 Ch. D. 320. See also Lawson on Contracts, Sect. 220; Dwight's Commentaries on Law of Persons and Personal Property, 393. 
to be well worthy of consideration whether a person putting out a prospectus does not undertake to say, 'I am telling you everything which it is really material for you to know; and I am putting before you the whole prospect of the enterprise on which you are entering.'" He did not pass on this question, but on the appeal it was considered and decided in the negative.

$\S 150$. In Peek v. Gurney, ${ }^{1}-\mathrm{a}$ bill in equity was brought by a shareholder of a company alleging misrepresentation and concealment of facts in a prospectus issued by the directors of the company, on the faith of which prospectus the shareholder had purchased his shares. The object of the bill was to obtain indemnity from the directors. The prospectus stated, among other things, that the company had been formed to purchase the business of the firm of Orerend, Gurney \& Co., the consideration for the good-will to be $£ 500,000$ payable one-half in cash, and the remainder in shares of the company. As a fact, the firm was insolvent to the extent of $£ 3,000,000$, and the good-will of the business was worthless, but this was not disclosed by the directors. It was held on the evidence that "there was, beyond the passive concealment of the state of affairs of the old firm, an active misrepresentation of the truth by the respondents for which they were answerable." But the question of the effect of the passive concealment or nondisclosure was also dealt with. Lord Chelmsford said:

"That there was a moral obligation upon the respondents not to put forward a scheme which depended for its success upon keeping the public in ignorance of what ought in fairness to be made known to them, no one can doubt. ... As this was an experiment which was to be made with the money of other persons as well as their own, they were bound to give all those other persons such information as they

1 L. R. 6 H. L. 377. 
themselves possessed, to enable a competent judgment to be formed as to the prudence of joining the proposed company. The question, however, is not as to the moral obligation of the respondents, but whether their intentional concealment, from whatever motive, of a fact so material that if it had been made known no company could have been formed, renders them liable to an action for damages, or to the analogous proceeding in equity, by the appellant, who was led by it to purchase shares in the company, by which he has been subjected to a most serious loss. This case is entirely different from suits instituted to be reliered from, or for the enforcement of, contracts induced by the fraudulent concealment of facts which ought to have been disclosed. . . . It is a suit instituted to recover damages from the respondents for the injury the appellant has sustained by having been deceived and misled by their misrepresentations and suppression of facts to become a shareholder in the proposed company of which they were the promoters. It is precisely analogous to the common-law action for deccit. There can be no doubt that equity exercises a concurrent jurisdiction in cases of this description, and the same principles applicable to them must prevail both in law and in equity. I am not aware of any case in which an action at law has been maintained against a person for an alleged deceit charging merely a concealment of a material fact which he was morally but not legally bound to disclose."

Lord Cairns said: "I entirely agree with what has been stated by my noble and learned friends before me, that mere silence could not, in my opinion, be a sufficient foundation for this proceeding. Mere non-disclosure of material facts, however morally censurable, however that non-disclosure might be a ground in a proper proceeding at a proper time for setting aside an allotment or a purchase of 
shares, would in my opinion form no ground for an action in the nature of an action for misrepresentation. There must, in my opinion, be some active misstatement of fact, or at all events such a partial and fragmentary statement of facts as that the withholding of that which is not stated makes that which is stated absolutely false." 1

$\S 151$. Statement of portion of truth with suggestions and inferences rendered credible only by suppression of other portions of truth. - But the statement of a portion of the truth, accompanied by suggestions and inferences which would be plausible and credible if it contained the whole truth, but becomes neither plausible nor credible whenever the whole truth is divulged, is a false statement. ${ }^{2}$ If by a number of statements you intentionally give a false impression and induce a person to act upon it, it is not the less false, although if one takes each statement by itself there may be difficulty in showing that every specific statement is untrue. ${ }^{3}$ Thus the promoters of a company issued a prospectus representing in substance that a mine acquired by the company had already been proved to be rich in gold, and only required the erection of machinery (tenders for which were about to be invited), in order to be at once in a position to make returns; that it was proposed to erect a forty-stamp mill in the first instance, and to make additions from time to time; that an average yield of one and one-half ounces per ton would yield .a monthly return of thirty-six hundred ounces of gold per month;

1 The omission from the prospectus in this case of reference to an agreement which would have made known the insolvency of the firm of Overend, Gurney, \& Co., is said to have occasioned the enactment of Sect. 38 of the Companies Act, 1867, which makes non-disclosure in a prospectus in certain cases fraudulent. Bramwell, L. J., in Twycross v. Grant, 2 C. P. D. at p. 499.

2 Per Lord Watson in Aaron's Reefs v. Twiss, A. C. (1896), 273.

8 Per Lord Halsbury, in Aaron's Reefs v. Twiss, supra; 1 Story's Equity, 201; Denny จ. Gilman, 26 Me. 149. 
the greater part of which would be available for distribution as dividends, and that it was not unreasonable to anticipate that the mine would readily and speedily pay dividends to the extent of one hundred per cent. The following facts were not disclosed: That three companies had tried to work the mine and had failed; that the mine had been recently purchased from one of these companies for $£ 2000$ and the assumption of liabilities of $£ 8000$; that the present company had acquired it under an agreement by which it was to pay as the purchase price $£ 131,000$ in stated instalments; that of the $£ 10,000$ which the subscribers were asked to pay on the shares during the first year, none would be available for working the mine; and that there would be no money arailable for that purpose until $£ 38,000$ of calls had been paid. In truth, the scheme of the promoters was to divide among themselres the money obtained from the public on the false pretence that it was to be used to develop the mine. In an action for calls on shares brought by the company against a subscriber, the subscriber claimed in his defence that he was induced to take the shares by false and fraudulent representations in the prospectus. "It is said," observed the Lord Chancellor, "there is no specific allegation of fact which is prored to be false. I protest against that being the true test. I should say, taking the whole thing together, was there false representation? I do not care by what means it is conreyed, by what trick or device or ambiguous language; all these are expedients by which fraudulent people seem to think they can escape from the real substance of the transaction. . . . When I look at the language in which the prospectus is couched, and see that it speaks of a property which requires only the erection of machinery to be either at once or shortly in a condition to do work so as to obtain all this valuable metal from the mine, it seems to 
me that although it is put in ambidextrous language, it means, as plainly as can be, that such is now the condition of the mine, that such and such additions to it will enable it shortly to produce all those great results, and that that is a representation of an actually existing fact. . . . You may use language in such a way as although in the form of hope and expectation, it may become a representation as to existing facts, and if it is so, and it is brought to your knowledge that these facts are false, it is a fraud. ...." 1

$\$ 152$. Rules as to misrepresentation and non-disclosure not the same in actions ex delicto as in suits for equitable relief. - While misrepresentation or non-disclosure of facts may be of such a nature as not to create a liability ex delicto, it may affect the ralidity or operation of a contract of subscription entered into on the supposition that the facts as stated are true, and that facts not stated do not exist. In equitable suits for rescission and specific performance, a stricter rule prevails, as we shall hereafter see. It is important to bear this distinction in mind in considering the decisions and dicta in relation to the duty of promoters as to accurately stating and fully disclosing all material facts in their knowledge touching the corporate enterprise.

$\S 153$. No legislation in this country requiring promoters' agreements to be disclosed in prospectuses. - In this country there is not, it is bcliered, any legislation requiring promoters of corporations who issue prospectuses, to disclose prior agreements material to intending subscribers to know. In England, frauds perpetrated by promoters by means of concealed agreements became common, and were found difficult to deal with. In Twycross v. Grant," Lord Coleridge said : "Their non-disclosure by no means neces-

1 Aaron's Reefs v. Twiss, A. C. (1896) 273.

22 C. P. D. at p. 484. 
sarily made a prospectus fraudulent; and, unless the prospectus was fraudulent, the deluded shareholders were generally without redress. To defeat frauds of this kind some law was required to compel the promoters of companies to disclose all agreements entered into by them, and affecting their own remuneration by the company directly or indirectly, the price to be paid by the company directly or indirectly for the property the company was formed to take, the qualifications or independence of the directors, the issue or control of the shares of the company. Experience showed that it was by means of secret agreements relating to matters such as these that unscrupulous promoters succeeded in enriching themselves at the expense of their dupes. In this state of things the 38th section of 30 \& 31 Vict. c. 131 was passed."

$\S 154$. English statute on subject. - By this section of an act known as the Companies Act, 1867 , it is provided that erery prospectus of a company, and every notice inviting persons to subscribe for shares, shall specify the dates and names of the parties to any contract entered into by the company or by the promotors, directors, or trustees thereof, before the issue of the prospectus, whether subject to adoption by the directors of the company or not, and that every prospectus or notice not specifying the same shall be deemed frandulent on the part of the promoters, directors, or officers knowingly issuing the same, as regards any person taking shares in the company on the faith of the prospectus, unless he had notice of the contract. This enactment does not affect the obligation of the promoters toward the corporation, but it imposes a fresh duty on their part toward subscribers for shares, and gires such subscribers a new canse of action against the promoter. ${ }^{1}$ The question

${ }^{1}$ Lord Blackburn in Erlanger v. New Sombrero Phosphate Co., 3 App. Cas. at p. 1269. 
as to just what contracts are meant by this enactment has given rise to considerable difference of judicial opinion. There are two conflicting views: The one, that only those contracts are meant which affect the company, which put an obligation on it, whether with or without some benefit attached. ${ }^{1}$ The other, that the section includes every contract made before the issue of the prospectus, the knowledge of which might have an effect upon a reasonable subscriber for shares in determining him to give or withhold faith in the promoter, director, or trustee issuing the prospectus, and whether or not such contract was made on behalf of, or so as if adopted to impose a liability on the company. ${ }^{2}$ The weight of authority is in favor of the latter interpretation. ${ }^{3}$

$\S 155$. Right of subscriber to rely upon representations adaressed to him. - The subscriber has usually a right to rely upon a representation of a material existing fact, the truth of which is not known to him. He is not bound to investigate, ${ }^{4}$ unless he has had actual notice sufficient to put him on his guard. ${ }^{5}$ And when the representation is contained in a prospectus, he is not chargeable with constructive notice of the contents of documents referred to, an examination of which would show the falsity of the representation. ${ }^{6}$ If the subscriber does not believe the

1 Bramwell, L. J., in Twyeross v. Grant, 2 C. P. D. at p. 499.

2 Brett, L. J., in Gover's Case, 1 Ch. D. at p. 200.

8 See Cornell v. Hay, L. R. 8 C. P. 328; Gover's Case, 1 Ch. D. 182 ; Craig v. Phillips, 3 Ch. D. 722 ; Twycross v. Grant, 2 C. P. D. 469 ; Sullivan v. Mitcalfe, 5 C. P. D. 455.

4 Central Ry. Co. of Venezuela v. Kisch, L. R. 2 H. L. 99 ; Mc Clellan v. Scott, 24 Wisc. 81 ; Mead v. Bunn, 32 N. Y. 275.

5 Warner $\nabla$. Seymour, 89 Wisc. 290; Salem Rubber Co. v. Adams, 23 Pick. 256.

- Central Ry. Co. of Venezuela $\nabla$. Kisch, supra: Aaron's Reefs Co. v. Twiss, A. C. (1896) 273. 
representation, or acts, not upon the representation, but upon his own judgment after investigation, there is no deceit. ${ }^{1}$ He must show that he relied upon or was materially influenced by the false statement, and that he was misled by it to his injury $;^{2}$ and it should be considered whether he was likely through inexperience to be misled by the prospectus. ${ }^{3}$ Of course, in order to recover he must show that he has suffered damage. ${ }^{4}$

$\S 156$. Liability of promoters on sale of shares issued to them at a discount or in payment for property at overvaluation. - It has been a not uncommon practice for promoters controlling the corporation in its inception to cause to be issued to themselves and their co-adventurers shares of the capital stock of the corporation at a discount or on a transfer of property to the corporation at a fraudulent overvaluation. The shares which they have thus obtained they then unload on the public before the bubble bursts. If in doing this, they knowingly falsely represent to purchasers of the shares that the capital of the corporation has been paid in, or that the shares are full paid shares, the purchasers have a right to rely on the representation, and if they are deceived to their injury, an action for deceit will lie against those who have been guilty of such fraudulent misrepresentation. ${ }^{5}$ Beyond this, in such case, probably

1 Brownlow v. Cauthers, 40 Ind. 90; Jennings v. Broughton, 22 L. J. Ch. 585; Haight v. Hayt, 19 N. Y. 464.

2 Smith v. Chadwick, 9 App. Cas. 187; Walker v. Mobile \& Ohio R. R. Co., 34 Miss. 245; Colton v. Stanford, 82 Cal. 351; Bennett v. Gibbons, 55 Conn. 450.

${ }^{8}$ Bellairs v. Tucker, 13 Q. B. D. 562.

4 Pasley v. Freeman, 3 T. R. 51; Ming v. Woolfolk, 116 U. S. 599 ; Danforth v. Cushing, 77 Me. 182; Windram v. French, 151 Mass. 547.

5 In re Ambrose Lake Tin \& Copper Mining Co., 14 Ch. D. at p. 397; Re Gold Co., 11 Ch. D. at p. 713; Flagler Engraving Co. v. Flagler, 19 Fed. Rep. 468 ; Priest v. White, 1 S. W. Rep. 361. 
the promoters might be convicted on an indictment for conspiracy, ${ }^{1}$ and, under some circumstances, the corporation might be entitled to a remedy against them. ${ }^{2}$ But suppose promoters, selling stock which they have obtained in the manner stated, make no misrepresentations, what remedy has the purchaser against them? It has been held that the usual statement contained in the certificate of stock, to the effect that the shares are full paid, amounts to a representation on which the purchaser has a right to rely. ${ }^{3}$ But this would not often be available in view of the fact that ordinarily the purchaser does not see the certificate until after the stock has been bought and the certificate issued or transferred to him. ${ }^{4}$ In order to recover he must prove that he knew and relied upon the representation alleged to be false and fraudulent. This question, however, is not perhaps of much practical importance, as it is not easy to conceive of a case of the nature stated in which the promoters could without some other fraudulent misrepresentation work off their shares on the public. ${ }^{5}$

\section{$\S 157$. Liability of promoters for misrepresentations made by} co-promoters. - One is of course liable for such misrepresentations as he has expressly authorized another to make in his behalf. It is also apparent that, if persons combine and conspire fraudulently to effect a common object, as, for example, to get up a bubble company and by means of fraudulent prospectuses to sell shares to the public, any

1 Bramwell, L. J., in In re Gold Co., 11 Ch. D. 701. See opinion of Best, Ch. J., in Duvergier v. Fellows, 5 Bing. 248.

2 See Chapter II.

${ }^{3}$ Cross v. Sackett, 2 Bosw. (N. Y.) 617; Windram v. French, 151 Mass. 547.

4 McAleer v. McMurray, 58 Penn. 126.

5 "I suppose there was some public announcement of the company as having a capital of $£ 100,000$ paid up, which was untrue. If anybody could prove that he had been deceived by that, he might be able to maintain an action against the fraudulent persons who had 
act done in furtherance of the common object, and in accordance with the general plan, becomes the act of all; all are alike responsible, the acts and words of one becoming the acts and words of all. ${ }^{1}$ But inasmuch as promoters are not presumptively partners, one is not prima facie liable for misrepresentations made by another. ${ }^{2}$ Accordingly, to hold a promoter responsible for the misrepresentations of a co-promoter, when the misrepresentation itself was not authorized, and there was no fraudulent combination, it must be shown, as matter of fact, that the promoter authorized his co-promoter, either expressly or impliedly, to act as his agent, and that the misrepresentation was made within the apparent scope of the authority, and in reference to the subject matter of the agency. ${ }^{3}$

$\S 158$. Conflicting views as to measure of damages. - There appear to be three distinct theories as to the true measure of damages in an action of deceit brought by a person who has been induced by false and fraudulent representations to take and pay for shares in a corporation. The respective measures under these theories are as follows.

$\S 159$. Rule in Massachusetts and other jurisdictions. First. The difference between the value of the shares at the time of their purchase and what the value would then have been had the representations been true. ${ }^{4}$ The objection to

deluded him and caused damage to him." Bramwell, L. J., in In re Gold Co., 11 Ch. D. 701.

1 Page v. Parker, 43 N. H. 363; Hornblower v. Crandell, 7 Mo. App. 220; Aff. 78 Mo. 581 . Stiles v. White, 11 Met. 356; Morehouse v. Yeager, $71 \mathrm{~N}$. Y. 594. Although some obtain no benefit from the fraud. Walsham v. Stainton, 1 De G., J. \& S. 678.

2 See Sect. 233.

${ }^{3}$ Meacham on Agency, Sect. 743, and cases there cited. See Weir v. Barnett, 3 Ex. D. 32 ; Cargill v. Bower, 10 Ch. D. 502.

${ }^{4}$ Hubbell v. Meigs, 50 N. Y. 480; Exchange Bank of Kentucky v. Gaitskill (Ky. 1896), 37 S. W. Rep. 160; Warner v. Benjamim, 89 Wisc. 290; Morse v. Hutchins, 102 Mass. 440; 1 Bigelow on Fraud, 628. 
this is that it permits a recorery for " the expected fruits of an unrealized speculation," instead of limiting the recovery to the actual, tangible loss. The action being for a tort, and not for the breach of a contract, the plaintiff's loss is not the value of his bargain, for, as Mr. Sedgwick observes, "it is necessary to the very maintenance of the action to show that the bargain would not have been made if the defendant had not made the false statements complained of. If these had not been made, therefore, the plaintiff would have the consideration he paid, but nothing more ; and the difference between that consideration and the actual value of the property represents all the loss that was caused by the defendant's tort." 1

$\$ 160$. Rule in New Jersey. - Second. In case the shares hare been purchased to hold as an investment, the difference between the price paid for the shares and their value at the time when the fraud ceases to be operative. ${ }^{2}$ If this is to be applied in all cases without qualification, it may put the shareholder in a better position than if the false representation had in fact been true, inasmuch as it eliminates the risk of loss or depreciation from extrinsic causes, while the shares are retained, until the fraud is discovered. The recovery should be limited to loss caused by defects inherent in the original project, and should not extend to loss occasioned by extrinsic causes, such as mismanagement or business depression. This has been stated and explained with great force and clearness by Chief Justice Cockburn, as follows: "If a man is induced by misrepresentation to buy an article, and, while it is still in his possession, it becomes destroyed or damaged, he can only recover the difference between the value as represented and the real value at the time he bought. He cannot add to it any further dete-

1 Sedgwick on Damages, Sth ed., Sect. 773.

2 Smith v. Duffy, 57 N. J. L. 679. 
riolation which has arisen from some other supervening cause. If a man buys a horse, as a race-horse, on the false representation that it has won some great race, while in reality it is a horse of very inferior speed, and he pays ten or twenty times as much as the horse is worth, and after the buyer has got the animal home it dies of some latent disease inherent in its system at the time he bought, he may claim the entire price he gave; the horse was, by reason of the latent mischief, worthless when he bought; but if it catches some disease and dies, the buyer cannot claim the entire value of the horse, which he is no longer in a condition to restore, but only the difference between the price he gave and the real value at the time he bought." 1

$\S$ 161. Rule laid down in England and by Supreme Court of the United States. - Third. The difference between the value of the shares at the time when they were purchased and the price paid, with interest and any other outlay legitimately attributable to the fraudulent representations. ${ }^{2}$ This is the rule adopted by the Supreme Court of the United States. It is also the rule in England. And it would seem to be the sounder and more reasonable rule. While the value is to be ascertained as of the time when the shares were taken, it is not conclusively fixed by what might then have been obtained for the shares in the market, because the purchaser, having invested, was not bound to sell at that time. Moreover, the inquiry is as to the real value, and the market price may have been factitious or a mistaken estimate of the real value. ${ }^{3}$

1 Twycross v. Grant, 2 C. P. D. at p. 544.

2 Smith v. Bolles, 132 U. S. 125; Twycross v. Grant, 2 C. P. D. 514 ; Peek v. Derry, 37 Ch. D. 541 ; Redding v. Godwin, 44 Minn. 355. In Buschman v. Codd, $52 \mathrm{Md}$. 202, the same rule was applied when the misrepresentation related to a business sold.

${ }^{8}$ Peek v. Derry, supra; Twycross v. Grant, supra; Smith v. Bolles, supra. 


\section{CHAPTER VIII.}

LIABILITY OF PROMIOTERS TO SUBSCRIBERS FOR SHARES IN A PROJECTED CORPORATION WHICH PROVES ABORTIVE.

\$162. Promoters, in such case, may be liable to refund moneys paid in advance on slares by subscribers.

163. No deduction allowed for expenses, unless subscriber has authorized deposit to be applied thereto.

164. What subscriber must prove in order to recover from promoters.
$\S 165$. Burnside v. Dayrell, 3 Ex. $2: 24$.

166. Criticism of Burnside $v$. Dayrell.

167. Subscriber has no lien on moneys advanced as against creditors of company.

168. Subscriber's remedy is at law, unless fraud shown, or accounting necessary.

169. Apperly v. Page, 1 Phill. 779.

$\$ 162$. If corporation proves abortive, promoters may be liable to refund moneys paid in advance by subscribers. - When a subscriber for shares in a projected corporation has paid money thereon in advance to the promoters, and the scheme proves abortive, he may recover back his money. This right rests on the failure of the consideration on which the money was paid. ${ }^{1}$ But the scheme is not to be deemed abortive until the formation of the corporation has been abandoned or has become impracticable, or a reasonable time for the formation has elapsed.2 It is reasonable, in the absence of agreement to the contrary, that the expense

1 Nockels v. Crosby, 3 B. \& C. 814; Walstab v. Spottiswoode, 15 M. \& W. 501 ; Ward v. Lord Lodensborough, 12 C. B. 254 ; Chaplin v. Clark, 4 Ex. 402 ; Grand Trunk Ry. Co. v. Brodie, 9 Hare, 822 . If the subscriber has given a note, instead of paying cash, he may plead as a defence the fact that the company has proved abortive. Bradford $\nabla$. Harris, 77 Md. 153.

2 Johnson v. Goslett, 3 C. B. (N. s.) at p. 590 ; Lindley on Company's Law, 5th ed., 29. 
of exploiting the proposed undertaking should, in case it collapses, fall upon the original projectors, and not on those who advanced their money on the faith of the ability of the projectors to do that which they undertook to do.

$\S 163$. No deduction allowed for expenses, unless subscriber has authorized his deposit to be so applied. - In Nockels v. Crosby, Littledale, J., said: "If persons set a scheme afoot, and assume to be the directors or managers, all the expenses incurred before the scheme is in actual operation must in the first instance be borne by them. When it is in operation, the expenses and charges of management should be borne by the concern, and then it may be fair that the preliminary expenses should be paid in the same way, for then the subscribers have the benefit of them. Suppose there had been no subscribers, the projectors must have paid all the expenses. If, then, one person only subscribes, are all those expenses to be cast upon him? The hardship and injustice would be monstrous, yet that would be the consequence in such a case were we now to hold that the plaintiff was liable to a proportion of the expenses incurred by these defendants."

Accordingly, on recovery of deposits paid in advance by a subscriber, no deduction is allowed on account of expenses which the promoters have incurred in attempting to bring about the formation of the corporation, ${ }^{2}$ unless the subscriber has expressly or impliedly authorized the expenditures. ${ }^{3}$

13 B. \& C. 814.

2 Nockels v. Crosby, 3 B. \& C. 814; Ashpitel v. Sercombe, 5 Ex. 147.

3 Baird v. Ross, 2 Macq. 61; Vane v. Cobhold, 1 Ex. 798; Willey v. Parrott, 3 Ex. 211; Aldhom v. Brown, 7 E. \& B. 164; 2 E. \& E. 398; Garwood v. Ede, 1 Ex. 264 ; Jones v. Harrison, 2 Ex. 52; West Point Foundry Association v. Brown, 3 Edw. Ch. (N. Y.) 284. 
\$164. What subscriber must prove in order to recover from promoters. - The subscriber, in order to recover his money, must prove that he paid it to the defendant or to the defendant's agent. As promoters are not, as such, partners, the payment of moneys by a subscriber to one of several promoters is not necessarily a payment to the others, and payment into a bank to the account of the company is not a payment to the promoter sought to be held, unless it is slown that he authorized the bank to receive the deposit on the account to which it was paid. Thus in Watson v. Earl of Charlemont, ${ }^{1}$ the plaintiff sued to recover deposits paid by him on shares in an abortive company. The three defendants were members of the committee of management. The letter of allotment sent to the plaintiff was signed by the secretary of the company, and contained a list of banks into any of which deposits might be paid. The plaintiff had paid his deposits into one of those banks, and had received from the bankers a receipt on account of certain persons as trustees for the company. Only one of the defendants was amongst the persons on whose account the receipt of the money was thus acknowledged. It was held that this evidence was insufficient to show a receipt by all the defendants, and the action therefore failed.

$\S 165$. In Burnside v. Dayrell, ${ }^{2}$ a subscriber for shares in a projected company paid his deposit into the bank named in the prospectus which had been circulated by the defendant's sanction, the defendant's name appearing therein as one of the provisional committee, and as chairman of the committee of management; but the defendant had not personally superintended the allotment of shares, and had taken no active part in the concern, and had been present once only at any meeting, when he acted in the capacity of chairman, but dissented from the proceedings ; in an action

112 Q. B. 856.

$23 \mathrm{Ex} .224$. 
by the subscriber against the defendant for the recovery of his deposit on the abandonment of the scheme, it was held that the defendant was not liable. Pollock, C. B., said : "The defendant can only be liable because he was the person, or one of the persons, to whom the deposit was paid. There was no evidence that such was the case in the present instance. The defendant never acted at all, except by once attending a meeting as chairman, and by concurring in the circulation of the prospectus. ... Although the money was paid to the bankers named in the prospectus, it was not paid to the use of the defendant, nor was there any proof that the defendant ever received, or could have received, any part of it." 1

$\S 166$. Criticism of Burnside v. Dayrell. - The correctness of the decision in this case may well be doubted. In the earlier cases of Nockels v. Crosby, ${ }^{2}$ and Walstab v. Spottiswoode ${ }^{3}$ the plaintiff proved that he had paid his deposits to the bankers appointed by the defendants to receive them, and this was regarded as sufficient. 4 And in the later case of Johnson v. Goslett, ${ }^{5}$ the defendants having issued a prospectus in which certain bankers were designated to whom deposits on shares might be paid, it was held that the prospectus was evidence against the defendants that money for shares might properly be paid to the bankers named in the prospectus. It was likewise held that all the defendants were responsible to the depositors for the moncy so paid in, the scheme having proved abortive, notwithstanding the fact that the bankers gave receipts as for the company, and though they entered the moneys received

1 Drouet $\nabla$. Taylor, 16 C. B. 671 , is to the same effect.

23 B. \& C. 814.

815 M. \& W. 501.

4 See also Hayes v. Stanley, 14 Ir. Com. Law Rep. 277; Maitland's Case, 4 De G., M. \& G. 769.

s 3 C. B. (N. s.) 569. 
to an account in the name of some only of the defendants. "That," it was said, "was an act between the bankers and the defendants subsequent to the paying in, with which those who liad paid in had no concern." Burnside $\mathrm{v}$. Dayrell being cited in argument, Martin, B., remarked: "That case was decided after the turning of the tide in the provisional committee cases."

$\S 167$. No lien by subscribers as against creditors of company. - Subscribers who have paid money on their shares, which has been deposited to the credit of the company, have no lien on such money as against creditors of the company. Thus, in Moseley v. Cressey's Co., ${ }^{1}$ the promoters of a company issued a prospectus stating that deposits would be returned if no allotment of shares was made. Several deposits were made, but no allotment ever took place. The depositors filed a bill to restrain creditors from attaching under a garnishee order the deposits which stood in a bank to the credit of the company. "If the object had been to create a lien of this kind," said Sir W. Page Wood, V. C., "the obvious way of doing so would have been to have said in the prospectus that there would be a lien on the deposits until the company was established, or that it was to be set apart as a trust fund in the name of trustees, to be returned in the event of the company not being established. Nothing of that kind was done; nor was that the contract. The contract was, You are to pay so much per share when you apply for shares, and your deposits will be returned if no allotment is made, - not that the actual thing so deposited was to be paid back; for payment to the company's bankers to the account of the company made the moneys ipso facto part of the company's assets. There are persons to be considered besides the depositors, - namely, creditors who supply 
their labor and goods to the company when registered, in the hope and expectation that they will be paid out of its assets; when they know there is a balance at the bankers, they furnish goods; but if they understand that the company has no credit at the bank, they do not trust it at all." Demurrer to bill allowed.

$\S 168$. Subscriber's remedy is at law, unless fraud shown, or accounting necessary. - The remedy to recover deposits on shares in an abortive company is by an action at law, ${ }^{1}$ and not by a suit in equity, unless in a case of fraud, or when an accounting is essential. ${ }^{2}$ Thus it has been held that when promoters issue a prospectus, not with a fair intention to establish a bona fide company, but as a snare to obtain subscriptions, the proposed enterprise being a "bubble," a mere scheme to cheat, subscribers may maintain a bill in equity to recover the moneys which they have paid on their shares. ${ }^{3}$ If the promoters have received money on subscriptions and used it in purchasing property, making a profit in the transaction, the profit may be secured for the benefit of the subscriber's on a bill by some in behalf of all, although the corporation has nerer been formed; the subscribers are not limited to the remedy of suing for a return of their deposits."

$\S 169$. In Apperly v. Page, ${ }^{5}$ a bill was brought by subscribers against promoters for an accounting, alleging that the promoters had been expending the deposits for unauthorized purposes, and praying tliat payments of legiti-

1 Denion $\nabla$. MacNeil, 2 Eq. 352.

2 Colt v. Woollaston, 2 P. Wms. 153; Green v. Barrett, 1 Sim. 45; Williams v. Page, 24 Beav. 654; Grand Trunk Ry. Co. ₹. Brodie, 9 Hare, 822 ; Williams $\nabla$. Salmond, 2 K. \& J. 463.

${ }^{8}$ Green v. Barrett, 1 Sim. 45 ; Blain v. Agar, 5 L. J. Ch. 1.

4 Butt . Monteaux, 1 Kay \& J. 98 ; 24 L. J. Ch. 99.

61 Phill. 779. 
mate expenses only from the deposits should be allowed, and the remainder returned to the subscribers. In returning deposits, it is a breach of trust to prefer particular shareholders. ${ }^{1}$

1 Williams v. Page, 24 Beav. 654; Clements v. Bowes, 1 Drew, 684; 21 L. J. Ch. 306. 


\section{CHAPTER IX.}

REMEDIES OF SUBSCRIBERS FOR SHARES AGAINST CORPORATION WHEN MISLED BY MISREPRESENTATIONS MIADE BY PROMOTERS OR BY THEIR NON-DISCLOSURE OF MIATERIAL FACTS.

Anticle I. - Liability of Corporation in Damages for Fraudulent Misrepresentations made by Promoters.

ARticle II. - Misrepresentation or Non-disclosure of Material Facts by Promoters as Ground for Rescission of Subscriptions for Shares, or as a Defence to Suits thereon by the Corporation.

Article I. - Liability of Corporation in Damages for Fraudulent Misrepresentations made by Promoters.

$\S 170$. Action of deceit will lie against a corporation.

171. Corporation not liable in damages for frauds committed by promoters prior to its formation.
$\S$ 172. Effect of insolvency of corporation on right of suit by subscriber against it to recover damages.

$\S 170$. Action of deceit will lie against a corporation. - It is sometimes laid down that an action for deceit will not lie against the corporation itself, because the gist of the action is fraudulent intent, and a fraudulent intent is not imputable to an artificial body. ${ }^{1}$ The modern doctrine, however, is otherwise. In Bank of Scotland v. Addie, ${ }^{2}$ it was said that an action for deceit could not be maintained

1 Thompson on Corporations, Sect. 1462; Cook on Stockholders, Sect. 157 ; Houston v. R. R. Co., 55 Tex. 176.

${ }^{2}$ L. R. 1 Sc. App. 145. 
against a corporation; but this was not necessary to the decision, and in the later case of Mackay v. Bank of New Brunswick, 1 it was directly held that such an action would lie. In, this country it has been generally held that the action will lie against the corporation. ${ }^{2}$

$\$ 171$. Corporation not liable in damages for frauds committed by promoters prior to its formation. - In order to make the corporation liable in damages to subscribers who have been led to take shares by false and fraudulent representations, it must be shown that such representations were made by agents of the corporation acting within the scope of their authority. In an action for damages on the ground of fraudulent misrepresentations, it is essential to prove knowledge by the defendant or his agent of the falsity of the statement alleged to have deceived the plaintiff. As a corporation cannot have agents before it exists, it follows that it is not liable in damages for misrepresentations made by its promoters, through prospectuses, or otherwise, before it comes into existence. Not having made the representations itself or by its agents, it is not responsible for them. ${ }^{3}$ But the promoters may, in fact, after its formation, act as its agents in procuring subscriptions for shares.

$\S 172$. Effect of insolvency of corporation on right of suit by subscriber against it to recover damages. - Subscriber's who have been induced to take shares by the fraud of the

15 P. C. 394. See also Houldsworth v. City of Glasgow Bank, 5 App. Cas. at p. 327.

${ }^{2}$ Dorsey Match Co. v. McCaffery, 139 Ind. 545; Nash v. Minnesota Title Ins. \& Trust Co., 163 Mass. 574; Bosley v. National Machine Co., 123 N. Y. 550, 555; Cragie v. Hadley, 99 N. Y. 131 ; Erie City Iron Works v. Barber, 106 Penn. 125; Fogg. v. Griffin, 2 Allen, 1; Peebles v. Patasco Guano Co., 77 N. C. 233 ; Cassidy v. Globe Rubber Co., 37 N. J. Eq. 175.

${ }^{8}$ Miller v. Wild Cat Gravel Road Co., 57 Ind. 241; Karberg's Case (1892), 3 Ch. at p. 13; Kennedy ₹. McKay, 43 N. J. L. 288 ; Presby v. Parker, 56 N. H. 409. 
agents of the corporation may be precluded from recovering damages from the eorporation when it has become insolvent. In Houldsworth v. City of Glasgow Bank, the plaintiff, who had taken shares in the defendant company on the faith of certain fraudulent misrepresentations made by its directors, brought an aetion against it for damages. The eompany was then insolvent and was being wound up. It was held that the action could not be maintained, the ground for the deeision being that " a shareholder eontracts to contribute a eertain amount to be applied in payment of the debts and liabilities of the eompany, and it is inconsistent with his position as a shareholder, while he remains such, to elaim baek any of that money." 2 The doetrine of this case, it has been said, is based on the winding-up provisions of the Companies Act, 1862, and upon the rights of creditors under winding-up proceedings, and has no application to companies not being wound up. ${ }^{3}$ The question of its applicability in this country to a shareholder's action against an insolvent corporation when proceedings have been instituted for a distribution of the assets among the ereditors, does not appear to have been mueh considered. 4

15 App. Cas. 317.

2 Per Lindley, L. J., in In re Addlestone Linoleum Co., 37 Ch. D. 191 ; Carling v. London \& Leeds Bank, 56 L. J. Ch. 321.

8 Lindley's Law of Companies, 5th ed., 777.

4 It has been held in Indiana that the shareholder may sue after the insolvency of the corporation, and while it is being wound up under a statutory assignment. Dorsey Match Co. v. McCaffrey, 139 Ind. 545. See Sects. 191, 192. 
Article II.-Misrepresentation or Non-disclosure of Material Facts by Promoters as Ground for Rescission of Subscriptions for Shares, or as a Defence to Suits thereon by the Corporation.

$\S 173$. Responsibility of corporation for misrepresentation or non-disclosure by promoters before corporation formed.

174. Subscribers' remedies against corporation for fraudulent misrepresentation by promoters.

175. Remedy when misled by non-disclosure of facts by promoters.

176. Dicta of Vice Chancellor Kindersley.

177. Dicta of Lord Chelmsford.

178. Standard of duty as to disclosure required by dicta quoted. Whether legal or moral duty.

179. Peek $v$. Gurney, L. R. 6 H. L. 377.

180. Duty to disclose material facts not a legal duty, when omission does not make facts stated false.

181. Absence of direct decisions on this point. Reasons for and against requirement of disclosure.

182. Contracts to take shares governed by maxim caveat emptor.

183. Views of Brett, J., expressed in Gover's Case, 1 Ch. D. 182.
$\S 184$. Relief obtainable in Equity, and in some jurisdictions at law, against innocent misrepresentation.

185. No relief at law where distinction in procedure between action at law and suit in Equity adhered to.

186. Principle on which Equity rescinds or refuses to enforce contract induced by innocent misrepresentation.

187. Proof necessary to obtain rescission of contract of subscription on ground of innocent misrepresentation.

188. Laches as a bar to rescission of contract of subscription.

189. Waiver of right to avoid subscription on ground of misrepresentation.

190. Burden of proof on question of laches or waiver.

191. Rule in Eugland as to effect of corporate insolvency on right to rescind contract of subscription.

192. Tendency of decisions in this country.

193. Repudiation of contract of subscription without suit for rescission effective, although corporate insolvency proceedings subsequently begun.

\section{$\S 173$. Responsibilty of corporation for misrepresentation} or non-disclosure by promoters prior to its formation. Although, as a general rule, a corporation is not responsible in tort or otherwise for misrepresentations made by pro- 
moters before the corporation comes into existence, ${ }^{1}$ still, when the contract of subscription has been induced thereby, a remedy may be had in certain cases against the corporation. When the corporation can be held, before the contract is complete, with the knowledge that it is induced by such misrepresentation, - as, for cxample, when the directors on allotting the shares know the fact that the application for them has been so induced, - the subscriber, if he comes seasonably, is entitled to rescission. ${ }^{2}$ A subscriber who acts seasonably may also procure rescission when he has subscribed on the faith of a prospectus containing misrepresentations, issued by promoters prior to the formation of the corporation. The application to the corporation, when formed, for shares, being based on the prospectus, cannot be dissevered by the corporation from the prospectus. "The offer to take shares," as Lindley, L. J., said, " is an offer to take them on the terms of the prospectus, and on no other terms; and the acceptance of the application by the allotment of shares is an acceptance of the offer on those terms, and not on other terms." 3 With these premises, a consideration may now be had of the subscribers' remedies against the corporation for misrepresentations by promoters for which the corporation is responsible.

$\S 174$. Subscribers' remedies against corporation for fraudulent misrepresentation by promoters. - A misrepresentation may be innocent or fraudulent. When it is fraudulent, and an action to recover damages for the deceit could be maintained, several remedies against the corporation are

1 Burnes v. Pennell, 2 H. L. C. 497; Felgate's Case, 2 De G., J. \& S. 456; Ex parte Worth, 4 Drew, 529; Duranty's Case, 26 Beav. 268; St. John's Mfg. Co. v. Munger (Mich. 1895), 64 N. W. Rep. 3; Belav v. Bryan, 89 Iowa, 348.

2 Lynde v. Anglo-Italian Hemp Spinning Co. 1 Ch. (1896), 178; Law v. Grant, 37 Wisc. 548 .

${ }^{8}$ Karberg's Case (1892), 3 Ch. 1. 
open to the subscriber, if he acts seasonably, in addition to that afforded by an action of deceit. 1 . If he has paid for his shares, in full or in part, he may, upon tender of his shares to the corporation, recover from it, in an action at law for money had and received, what he has paid. ${ }^{2}$ 2. He may, when sued by the corporation upon the subscription, interpose the fraud as a defence. ${ }^{3}$ 3. He may begin a suit in equity to rescind the subscription and to recover payments, if any, which he las made thereon. "This," says Mr. Cook, "is the most fair, safe, and convenient remedy that the subscriber has. It is a decisive notice to the corporation and all third parties not to rely upon the subscription in question. It avoids the risk of future corporate insolvency. It enables the subscriber to set aside the contract, to enjoin actions at law for calls, and to recover back payments made before discovery of the fraud." 4 And when several persons have been induced to subscribe for shares by the same fraudulent misrepresentations, as in the case of a fraudulent prospectus addressed to all of them, and on which they all act, they may join in a bill against the corporation and the promoters who issued the prospectus, to procure rescission of their subscriptions and to recover the moneys paid thereon. ${ }^{5}$ In decrecing rescission, the Court will allow interest on the money actually paid by the subscriber on his shares. Interest is not allowed by way of damages, but on the ground that the parties are to be restored as far as possible to their original position. ${ }^{6}$

1 As to what is seasonable action, see Sects. 188, 193.

2 Granger's Ins. Co. v. Turner, 61 Ga. 561; Hamilton v. Granger's Ins. Co., $67 \mathrm{Ga} .145$.

8 Deposit Life Ins. Co. v. Ayscough, 6 E: \& B. 761 ; Bivleh-y-plom Lead Mining Co. v. Baynes, 36 L J. (Ex.) 183; Sanford v. IIandy, 23 Wend. 260; Crump v. U. S. Mining Co., 7 Gratt. (Va.) 353.

4 Cook on Stockholders, Sect. 155.

- Bosher $\nabla$. Richmond \& Harrisonburg Land Co., 89 Va. 455.

- Karberg's Case (1892), 3 Ch. 1. 
$\S 175$. Subscribers' remedy against corporation when misled by non-disclosure of material facts by promoters. - An action of deceit will not lie for non-disclosure of material facts, when it is not such as to render the statement actually made a misrepresentation. ${ }^{1}$ The question then arises whether for non-disclosure of this nature, by which a subscriber has been misled, any remedy against the corporation may be had. While the rule is that mere non-disclosure does not create a liability ex delicto, it may affect the validity or operation of the contract in a certain exceptional class of contracts, such as contracts of insurance, in which the duty of disclosure is imposed by law. It is said by Sir Frederick Pollock, that contracts to take shares in corporations fall, by analogy to contracts of partnership, within the class of contracts thus exceptionally treated," "inasmuch as the public to whom promoters address themselves are for the most part not versed in the particular kind of business proposed, but are simply persons in search of an investment for their money, and with slight means at hand, if any, of verifying the statements made to them." 3 Another eminent English writer also lays it down that in contracts to take shares in corporations there is a special duty to disclose material facts, a breach of which may invalidate the contract. ${ }^{4}$ But no case can be found, it is believed, in which it has been decided that promoters merely as such or other persons soliciting subscriptions for shares of stock of a corporation are subject to a legal duty to disclose the

${ }^{1}$ See Sects. $149,150$.

2 But Sir William Anson asserts that contracts of partnership do not require a full disclosure of all facts which might affect the judgment of the intending partner, nor the same fulness of disclosure which, in his opinion, is necessary to the contract to allot shares. Anson on Contracts, 159.

3 Pollock on Contracts, 487, 508.

4 Anson on Contracts, 6th ed., 158. 
material facts touching the proposed corporate enterprise, un. less they have put themselves in a fiduciary position toward the persons with whom they deal. Sir Frederick Pollock and Sir William Anson support their propositions by reference to certain dicta by Kindersley, V. C., and Lord Chelmsford.

$\S 176$. Dicta in New Brunswick \& Canada Ry. Co. v. Muggeridge. ${ }^{1}$ - Vice-Chancellor Kindersley said: "Those who issue a prospectus holding out to the public the advantages which will accrue to persons who will take shares in the proposed undertaking, and inviting them to take shares on the faith of the representations therein contained, are bound to state everything with strict and scrupulous accuracy, and not only to abstain from stating as a fact that which is not so, but to omit no one fact within their knowledge, the existence of which might in any degree affect the nature, extent, or quality of the privileges and advantages which the prospectus holds out as inducements to take shares."

$\S 177$. Dicta in Central Ry. Co. of Venezuela v. Kisch. ${ }^{2}-$ Lord Chelmsford, referring to a prospectus, observed: "In an advertisement of this description some allowance must always be made for the sanguine expectations of the promoters of the adventure, and no prudent man will accept the prospects which are always held out by the originators of every new scheme without considerable abatement. But although on its introduction to the public some high coloring and even exaggeration in the description of the advantages which are likely to be enjoyed by the subscribers to an undertaking may be expected, yet no misstatement or concealment ought to be permitted. In my opinion, the

11 Dr. \& Sm. at p. 381 ; S. C. 30 L. J. Ch. 242 . This was a bill by the company for specific performance of a subscription for shares.

${ }^{2}$ L. R. 2 H. L. at p. 113 . This was a bill to rescind a subscription for shares. 
public who are invited by a prospectus to join any new adventure ought to have the same opportunity of judging of everything which has a material bearing on its true character as the promoters themselves possess. It cannot be too frequently or too strongly impressed upon those who, having projected any undertaking, are desirous of obtaining the co-operation of persons who have no other information on the subject than that which they choose to conrey, that the utmost candor and lionesty ought to characterize their published statements."

$\S 178$. Standard of duty as to disclosure required by dicta quoted. Whether legal or moral duty. - The rule as to strict accuracy of statement laid down in the dicta of Vice Chancellor Kindersley is somewhat modified, it will be observed, in the dicta of Lord Chelmsford; but there is an agreement in this, that it is the duty of promoters issuing a prospectus to disclose all material facts within their knowledge. This is not so high a standard as that maintained in marine insurance, where the assured must not only communicate to the insurer information of all material facts touching the risk of which the assured has knowledge, but must disclose all material facts of which in the ordinary course of business he ought to have knowledge, and must use due diligence to obtain all due information as to the subject matter of the insurance. Whatever the duty of disclosure in a prospectus inviting share subscriptions may be, "it is not the same," to use the language of Lord Watson in a late case in the House of Lords, "as in the case of a proposal for marine insurance. In an honest prospectus many facts and circumstances may be lawfully omitted, although some subscribers might be of the opinion that these would have been of materiality as influencing the exercise of their judgment." 1

1 Aaron's Reef Co. v. Twiss (1896), A. C. 273. 
Assuming that it is the duty of promoters who issue a prospectus to induce share subscriptions, to disclose all material facts within their knowledge, the question arises whether this is, as contended by Sir Frederick Pollock and Sir William Anson, a legal duty.

$\S 179$. In Peek v. Gurney, ${ }^{1}$ the plaintiff having taken shares in a company, on the faith of a prospectus, and having sustained loss thereby, brought a suit for damages against the persons by whom the prospectus was issued. He set up the non-disclosure by those persons of material facts within their knowledge, - facts so material that if they had been disclosed no subscriptions could have been obtained. In the argument, the dicta of Vice Chancellor Kindersley and of Lord Chelmsford were quoted and relied upon. In delirering judgment, Lord Chelmsford said: "That there was a moral obligation upon the respondents not to put forward a scheme which depended for its success upon keeping the puiblic in ignorance of what ought in fairness to be made known to them, no one can doubt.... As this was an experiment which was to be made with the money of other persons as well as their own, they were bound to give all those other persons such information as they themselves possessed to enable a competent judgment to be formed as to the prudence of joining the proposed company. The question, however, is not as to the moral obligation of the respondents, but whether their intentional concealment, from whatever motive, of a fact so material that if it had been made known no company could have been formed, renders them liable to an action for damages, or to the analogous proceeding in equity, by the appellant, who was led by it to purchase shares in the company, by which he has been subjected to a most serious loss. This case is entirely

1 L. R. 6 H. I. 377. 
different from suits instituted to be relieved from, or for the enforcement of, contracts induced by the fraudulent concealment of facts which ought to have been disclosed. ... It is a suit instituted to recover damages from the respondents for the injury the appellant has sustained by having been deceived and misled by the misrepresentation and suppression of facts to become a shareholder in the proposed company of which they were promoters. It is precisely analogous to the common law action for deceit. There can be no doubt that equity exercises a concurrent jurisdiction in cases of this description, and the same principles applicable to them must prevail both in law and in equity. I am not aware of any case in which an action of law has been maintained against a person for an alleged deceit charging merely a concealment of a material fact which he was morally, but not legally, bound to disclose."

Lord Cairns said: "Mere non-disclosure of material facts, however morally censurable, however that non-disclosure might be a ground in a proceeding at a proper time for setting aside an allotment on a purchase of shares, would, in my opinion, form no ground for an action in the nature of an action for misrepresentation. There must in my opinion be some active misstatement of fact, or, at all events, such a partial and fragmentary statement of facts as that the withholding of that which is not stated makes that which is stated absolutely false."

$\S 180$. Duty to disclose material facts not a legal duty, when omission does not make facts stated false. - The natural deduction from the decision in this case would seem to be that, while there is a moral, there is not a legal duty incumbent upon promoters who invite subscriptions for shares to disclose all material facts within their knowledge; that the legal duty of promoters in respect to disclosure, is simply not 
to omit a statement of facts when such omission would make the statement which has been made false. The question of the riglit of a subscriber to be reliered from his subscription, in equity, on the ground that he has been misled by a breach of the moral duty of the promoters in failing to disclose facts which were material, but the non-disclosure of which did not have the effect of rendering the statement actually made false, is suggested, but not decided. ${ }^{1}$

$\S 181$. Absence of direct decisions on question. Reasons for and against requirement of disclosure. - The theory that a subscriber may be relieved from his contract of subscription, when he can show that he would not have entered into the contract if the persons who induced him to do so by means of representations had disclosed every material fact within their knowledge which might have influenced his judgment in determining the expediency of becoming a subscriber, is not affirmed nor denied, ${ }^{2}$ it is believed, by any direct decision. As conducive to fair dealing and for the protection of the ignorant, the careless, and the trusting, in such transactions, it may be dcemed desirable that the remedy stated should be afforded. "The general public," said Lord Bramwell, "is so at the mercy of promoters, sometimes dishonest, sometimes over-sanguine, that it requires all the protection that the law can give it." 3

"There are cases," said Chief Justice Cockburn, "in which, in the absence of active fraud, passive misrepresentation, that is to say, silence as to some fact which it

1 See also Arkwright v. Newbold, 17 Ch. D. 301.

2 In Pulsford v. Richards, 17 Beav. 87, Heymann v. European Central Ry. Co., $7 \mathrm{Eq}$. 154, and Doris v. French, 4 Hun, 292, there was nondisclosure, and relief was refused, but it appears to have been on the ground that the facts withheld were not such as to warrant subscribers in saying that if they had known of them they would not have taken shares.

3 Derry v. Peek, 14 App. Cas. at p. 344. 
would be material to the one party to know, but which the other is not legally bound to communicate, may involve the one in loss, but in which the party suffering what amounts to a moral, but not a legal wrong, has no remedy at law. In the ordinary transactions of life, an individual can make inquiries and require positive information, or insist on a warranty, before entering into a contract, or embarking in a common enterprise. But in these vast undertakings, carried on by the united enterprise and capital of hundreds, perhaps thousands, of shareholders, the individual shareholder is more or less at the mercy of those who invite him to join the company, as to the facts on which he may be led to invest his money." 1 On the other hand, it may be thought better "to teach people to look after themselves, and not have this sort of paternal legislation taking care of them and giving them information they will not take the trouble to ask for." 2

\section{$\S 182$. Contracts to take shares apparently governed by} maxim caveat emptor. - But, howerer this may be, not only is there an absence of adjudication in support of the theory maintained by Sir Frederick Pollock and Sir William Anson, that the mere non-disclosure of material facts may affect the validity and operation of a contract to take shares in a corporation, but the dicta relied on by them indicate, it is submitted it has been shown, merely a moral, and not a legal, duty of disclosure. Moreorer, in these dicta there is no expression of opinion on the question, whether, under any circumstances, a breach of this duty entitles a subscriber who has been misled thereby to be relieved in equity. Opposed to the view that relief

1 Twycross v. Grant, 2 C. P. D. at p. 532.

${ }^{2}$ Bramwell, L. J., construing the section of the Companies Acts which relates to disclosure in prospectuses, in Twycross v. Grant, supra, at p. 498. 
may be had in such a case, is the view expressed by Lord Justice Lindley in his work on the Law of Companies: "In all contracts of buying and selling, the maxim is caveat emptor; and contracts to take shares are apparently governed by this rather than by any other principle." 1

$\S$ 183. In Gover's Case, ${ }^{2}$ Brett, J., stating the law as it appeared to him to have been before the enactment of that section of the Companies Act which makes non-disclosure of certain contracts, when a prospectus is issued, fraudulent, said: "For mere non-disclosure, fraudulent or otherwise, which had not the effect of rendering that which was disclosed or stated a misrepresentation, however otherwise important for the consideration of an intended subscriber, there was no remedy, either in law or equity, if he became a registered shareholder." In a late case in the Court of Appeal, Rigby, L. J., said: "I think the law is this, - that if a person relies, as a ground for the rescission of a contract, on the omission of a statement, he must show that the omission of that statement makes what is stated misleading. It is not that omission of material facts is an independent ground for rescission, but the omission must be of such a nature as to make the statement actually made misleading." 3 In other words, relief is not obtainable in cases of pure non-disclosure of or simple silence as to material facts.

$\$ 184$. Relief obtainable in Equity, and in some jurisdictions at law. - In an action to recover damages for misrepresentation it is essential, as we hare seen, to show that the party who made the misrepresentation had knowledge of its falsity at the time it was made. But a misrepresen-

1 Lindley's Law of Companies, 5th ed., p. 70.

21 Ch. D. 182.

McKeon v. Boudard, Peveril Gear Co. (1896), 65 L. J. Rep. s. s. 735 . 
tation may be an invalidating circumstance in a contract induced by it, although knowledge of its falsity is not shown. Equity will in a proper case relieve against an innocent mislepresentation, ${ }^{1}$ and in sereral States relief may be had at law.

$\S 185$. No relief at law where distinction in procedure between action at law and suit in Equity adhered to. - In those jurisdictions where the distinction in procedure between actions at law and suits in equity has been preserved, an innocent misrepresentation, where there was not a duty to be careful or to state the facts correctly, will not ground an action or a defence to an action at law. Consequently a subscriber who has been led into taking his shares by an innocent, as distinguished from a fraudulent misrepresentation, canmot in such jurisdictions avail himself of that fact as a defence to an action at law brought by the corporation on the contract of subscription, nor can he, in case he has repudiated the contract and tendered back his shares, on the ground of the misrepresentation, maintain an action at law to recover moneys paid by him on the shares. ${ }^{2}$ His remedy

1 Redgrave v. Hurd, 20 Ch. D. 1 ; Newbiggin v. Adam, 34 Ch. D. 582 ; Karberg's Case (1892), 3 Ch. 1; Peek v. Derry, 14 App. Cas. at p. 359; Wilcox v. Iowa Wesleyan University, 32 Iowa, 367; Mohler $\nabla$. Carder, 73 Iowa, 582 ; Groppengiesser v. Lake, 103 Cal. 37; Yeater v. Hines, 24 Mo. App. 619; Kountze v. Kennedy, 147 N. Y. 124; 1 Bigelow on Fraud, 414. In Goodwin v. Mass. Loan \& Trust Co., 152 Mass. at p. 201, Field, Ch. J., said: "It does not seem to have been much considered in this Commonwealth whether the misrepresentation on account of which a contract can be rescinded must be in all respects the same as that on which an action for deceit can be maintained; although in England and in many of the States of this country a clear distinction has been taken between the two, ... and it may deserve consideration hereafter whether a contract cannot be rescinded for a misrepresentation or a concealment of facts, which would not support an action of deceit."

${ }^{2}$ Salem Mill Dam Co. v. Ropes, 9 Pick. 187; King v. Eagle Mills, 
is to bring a bill in equity to rescind the contract, and to enjoin the prosecution of an action upon it by the corporation. But where equitable claims and defences may be set up at law, it would seem that the rule is otherwise, and that the principle upon which equity affords relief to one who has been led into a contract by an innocent misrepresentation may be invoked at law. ${ }^{1}$

$\$ 186$. Principle on which Equity acts in matter of innocent misrepresentation. - The principle on which equity acts in setting aside or refusing to enforce a contract induced by an innocent misrepresentation is that it is a constructive fraud for one to insist on obtaining or retaining a benefit under a contract procured by his own untruthful statement, however innocent he may have been in the first instance in making that statement. ${ }^{2}$

$\S 187$. Proof necessary to obtain rescission of contract of subscription on ground of innocent misrepresentation. - To entitle a subscriber for stock to rescind or to procure the setting aside of the contract of subscription, on the ground of simple misrepresentation, the same things must be prored as in an action of deceit, excepting knowledge by the defendant of the falsity of the representation, and, when the contract is executory, damage to the defendant. ${ }^{3}$ When the contract is executed, it would seem that proof must be furnished that injury has resulted to the party seeking relicf. 4 When the misrepresentation which induced the contract was made by promoters before the

10 Allen, 518 ; Goodrich v. Reynolds, 31 Ill. 490 ; Parmelee v. Adolphe, 28 Ohio St. 10 ; Kennedy v. Panama Mail Co., L. R. 2 Q. B. 580.

11 Bigelow on Fraud, 414.

2 Redgrave v. Hurd, 20 Ch. D. 1; Homes' Appeal, 77 Penn. 50; Swimm v. Bush, 23 Mich. 99.

81 Bigelow on Fraud, 541.

4bid.; Jewett v. Davis, 10 Allen, 68; MLarriner $\nabla$. Dennison, $78 \mathrm{Cal}$. 202; Henninger $\nabla$. Heald, 52 N. J. Eq. 431. 
formation of the corporation, or afterwards by promoters not acting as its agents, the subscriber cannot, with a single exception, rescind the contract unless he can show that, at the time of its acceptance by the corporation, the corporation knew that it was induced by the misrepresentation. The exception is when the subscription was made on the faith of a prospectus, containing a misrepresentation issued by the promoters. In this case it is not necessary to prove that the corporation had knowledge of the misrepresentation at the time the shares were allotted, for the application for shares cannot be dissevered from the prospectus. ${ }^{1}$

$\S 188$. Laches as a bar to rescission of contract of subscription. - In discussing laches as a bar to a subscriber's remedy against the corporation, a learned writer states that " in the remedies by action at law the statute of limitations gorerns." 2 Undoubtedly the statute would prevail as a bar at law, and also in equity. But delay for a shorter period than the statutory limitation may, as constituting wairer, at law, as well as in equity, defeat the right to rescission. ${ }^{3}$ To rescind the contract, or to have it set aside, the subscriber must, within a reasonable time after learning, or after he might and should lave learned the truth, repudiate the contract and tender back his shares, or bring a bill for rescission. He will not be permitted to wait and see how the speculation turns out, in order that he may shape his action accordingly. "A man must not play fast and loose; he must not say, 'I will abide by the company if successful, and I will leave the company if it fails ;' and therefore,

1 Tamplin's Case (1892), W. N. 146. See Section 173. The remedy is limited to the subscriber. It does not extend to a vendee of a shareholder, because the office of the prospectus is exhansted when the shares are allotted. Peek v. Gurney, L. R. 6 H. L. 377.

${ }^{2}$ Cook on Stockholders, Sect. 161.

${ }^{8}$ Duffield v. E. T. Barnum Wire \& Iron Works, 64 Mich. 293; Perley v. Balch, 23 Pick. 283. 
when a misrepresentation is made of which any one of the shareholders has notice and can take advantage to avoid his contract with the company, it is his duty to determine at once whether he will depart from the company, or whether he will remain a member." 1 It is generally a question of fact, but in some circumstances a question of law, as to what is a reasonable time. ${ }^{2}$

$\S 189$. Waiver of right to avoid subscription on ground of misrepresentation. - The subscriber may waive his right to aroid the contract on account of misrepresentation. Acts, after discovery of the truth, inconsistent with an intention to rescind the contract, may constitute such waiver. Thus, by attending a stockholder's meeting, and voting for a levy of an assessment on the capital stock, and subsequently paying the assessment without objection, ${ }^{3}$ or by demanding or receiring a dividend, ${ }^{4}$ the subscriber may.

1 Lord Romilly, in Ashley's Case, 9 Eq. 263 ; Taite's Case, 3 Eq, 795; Peek's Case, 2 Ch. 674; Wilkinson's Case, 2 Ch. 536; Heymann v. European Central Ry. Co., 7 Eq. 154; Directors of Central Ry. Co. v. Kisch, L. R. 2 H. L. 99 ; Oakes v. Turquand, L. R. 2 H. L. 325 ; In re Scottish Petroleum Co., 23 Ch. D. 413 ; Farrar v. Walker, 3 Dill. (U. S.) 506 ; Upton v. Tribilock, 91 U. S. 45; Learing v. Wise, 73 Penn. 173; Dynes v. Schaffer, 16 Ind. 165; Parsons v. McKinley, 56 Minn. 464; Cedar Rapids Ins. Co. v. Butler, 83 Iowa, 124 ; State v. Jefferson Turnpike Co., 3 Humph. (Tenn.) 305.

${ }^{2}$ Hill v. Hobart, 16 Me. 164; Holbrook v. Burt, 22 Pick. 546; Fleming v. Weagley, 32 Ill. App. 183; Collins v. Townsend, 58 Cal. 608; Page v. McMillan, 41 Wisc. 337; Morgan v. McKee, 77 Penn. 228; Boughton v. Standish, 48 Vt. 594.

But when a stockholder's shares have been forfeited for non-payment of an assessment thereon, it is not incumbent upon him to take any active step to aroid the contract of subscription if it was induced by misrepresentation; he is justified in awaiting the company's attack; and when the company brings suit against him he may plead the misrepresentation as a defence. Aaron's Reef Co. v. Twiss (1896), A. C. 273 .

- Marten v. Paul O. Burns Wine Co., 99 Cal. 355.

4 Weiseger v. Richmond Ice Machine Co., 90 Va. 795. 
waive his right to relief. Such acts, however, are not conclusive on the question. ${ }^{1}$ When the stock has been tendered in rescission and refused, the subscriber has a right to do any acts in regard to the stock reasonably necessary to protect his interests, and at the same time to maintain his claim to rescind. The jury may infer from acts of ownership prima facie inconsistent with the demand for rescission, that the subscriber has waived his demand, but the apparent inconsistency may be dissipated by evidence that such acts were properly done in the way of protection only, the right to rescind being at the same time insisted upon. ${ }^{2}$

$\S 190$. Burden of Proof. - The burden of proof to establish laches or waicer is on the corporation. Accordingly, in an action for calls on shares, when the defendant pleads that he was induced to take the shares by fraud, it is not for him to show that he repudiated the contract as soon as he becamc aware of the fraud, but it is for the plaintiff to show that the defendant adhered to the contract notwithstanding his discovery of the fraud. ${ }^{3}$

$\S 191$. English rule as to effect of corporate insolvency on right to rescind subscription. - It is settled in England that the right of a subscriber to avoid the contract of subscription is lost, unless he rescinds the contract and brings suit to procure the removal of his name from the list of shareholders before proceedings are instituted by or against the corporation for a distribution of its assets on account of insolvency. But the subscriber is in time if le brings his suit prior to such proceedings, although the corporation is as a

1 Stewart's Case, 1 Ch. 574; Wontner v. Sharp, 4 C. B. 404; Philadelphia, Wilmington, \& Baltimore R. R. Co. v. Cowell, 28 Penn. 329; McCully v. Pittsburg \& Connellsville R. R. Co., 32 Penn. 25.

2 Jessop v. Ivory, 158 Penn. 71.

3 Aaron's Reef v. Twiss (1896), A. C. 273; Lindsay Petroleum Co. v. Hurd, L. R. 5 P. C. 221. 
fact insolvent when his suit is begun. ' The rule is based on the provisions of the winding-up acts. ${ }^{2}$ Under these acts, a public officer is appointed to keep a register of, amongst other things, the name of the projected company, a statement of the nature of the intended business, the amount of its capital, the names and addresses of subscribers, with the number of shares taken by them, and the amount paid on each share. And it is provided that, in the event of a company being wound up, every member shall be liable, if the company is a limited liability company, to pay in the amount unpaid on his shares, or, if the liability of the shareholders is not limited, to pay in an amount sufficient to satisfy the claims of creditors. The status of registered shareholders as contributories is thus fixed by winding-up proceedings. $^{3}$

$\$ 192$. Tendency of decisions in this country. - In this country, the tendency of the decisions is toward the view that creditors of the corporation who become such subsequent to stock subscriptions, and without notice of equities between

1 Oakes v. Turquand, L. R. 2 H. L. 325 ; Reese River Silver Mining Co. v. Smith, L. R. 4 H. L. 64 ; Tennent v. City of Glasgoiv Bank, 4 App. Cas. 615; Carling v. Bank of London \& Leeds, 56 L. J. Ch. 321.

2 In re Scottish Petroleum Co., 23 Ch. D. 413.

8 Compare the United States National Banking Act, which provides that a certificate shall be filed with the Comptroller of the Currency, containing, among other things, a statement of the capital stock of the proposed banking corporation, the number of shares into which it is divided, the names and places of residence of the shareholders and the number of shares held by each of them. The corporation is required to keep a list of the shareholders open to the inspection of shareholders and creditors, and annually to transmit a copy of such list to the Comptroller of the Currency. Shareholders are individually responsible for the corporate debts to an amount equal to the par value of their shares, in addition to the paid.up value. On a winding-up, a receiver is authorized to enforce this individual liability. U. S. Revised Statutes, Sect. 5133 et seq. 
the subscribers and the corporation, stand, as to those subscriptions, to the extent of their equitable lien, in the position of innocent purchasers for value. As against such creditors, the subscriber's right to rescind his contract of subscription is lost if not exercised before corporate insolvency proceedings, voluntary or involuntary, have been instituted, or some act done that is in law regarded as an act of insolvency. It makes no difference in what aspect the question is raised, - whether the subscriber who has paid for his stock repudiates the contract on the ground of misrepresentation, and sues to recover what he has paid, or whether he is sued for the amount unpaid on his subscription, and defends on the ground of misrepresentation. If, in consequence of his apparent relations with the corporation as a subscriber, innocent third parties have, upon the faith of such relations, acquired rights which would be prejudiced by a rescission of the contract of subscription, the subscriber will not be allowed, in the one case, to withdraw what he has paid in, or, in the other case, to escape payment. ${ }^{1}$

$\S 193$. Effect of repudiation of subscription without suit. Repudiation by any act or acts of the subscriber which in law amount to a rescission, as, for example, when the subscriber notifies the corporate authorities that he repudiates

${ }^{1}$ Morawetz on Corporations, Sects. 839, 840; Duffield v. E. T. Barnum Wire \& Iron Works, 64 Mich. 293; Savage v. Bartlett, 78 Md. 561; Howard v. Turner, 155 Penn. 350; Ramsey v. Thompson Mfg. Co., 116 Mo. 313; Michener v. Payson, 13 Nat. Bank Reg. 49; Webster v. Upton, 91 U. S. 65 ; Upton v. Tribilock, 91 U. S. 45; Sanger v. Upton, 91 U. S. $56 ; C h u b b$ v. Upton, 95 U. S. 665 ; Ogilvie v. Knox, 22 How. (U. S.) 380; Upton v. Englehart, 3 Dill. 496 . Compare Cunningham v. Edgefield \& Kentucky R.R. Co., 2 Head (Tenn.), 23; Ashmead v. Colby, 26 Conn. 287; Turner v. Grangers' Life \&. Health Ins. Co., 65 Ga. 649; Hamilton v. Grangers' Life \& Health Ins. Co., 67 Ga. 145; Jewell v. Rock River Paper Co., 101 Ill. 57; Reeder v. Maranda, 66 Ind. 486. 
the contract, and tenders back his shares, is effective without a suit against the corporation to set the contract aside, although insolvency proceedings are subsequently begun; and in such case it is not necessary, at least in those jurisdictions where a public registry of the shareholders is not required by law to be kept, to begin suit before insolvency proccedings to procure the removal of the shareholder's name from the register of shareholders. ${ }^{1}$

1 Savage v. Bartlett, 78 Md. 561; Fear v. Bartlett (Md. 1895), 32 At. Rep. 322; Upton v. Englehart, 3 Dill. 496; Newton Nat. Bank v. Newbiggen, 74 Fed. Rep. 135. Mr. Justice Miller has expressed the opinion that a defrauded subscriber has the right to repudiate the contract of subscription after the insolvency of the corporation, if he has not had a reasonable time to examine into the affairs of the corporation before the appointment of the assignee. Farrar v. Walker, 3 Dill. 506. See also Haskell v. Worthington, 94 Mo. 560. 


\section{CHAPTER X.}

\section{RIGHTS AND LIABILITIES OF CORPORATION ON PROMOTERS' CONTRACTS.}

Article I. - Enforcement by or against the Corporation of Contracts made in its Name and for its Benefit by its Promoters before it comes into Existence.

ARticle II. - Liability of Corporation to pay its Promoters, or Persons employed by them, for Services and Expenses incident to its Formation.

Article I. - Enforcement by or against the Corporation of Contracts made in its Name and for its Benefit bX its Promoters before it comes into Existence.

§ 194. Such contracts as a rule primarily not binding upon or enforceable by the corporation.

195. Penn Match Co.v. Hapgood, 141 Mass. 145.

196. Long $v$. Citizens' Bank, 8 Utah, 104.

197. Gooday v. Colchester, \&c. Ry. Co., 17 Beav. 132.

198. Buffington $v$. Barden, 80 Wisc. 635 .

199. By weight of authority, corporation cannot ratify contract made for it before its creation.

200. Doctrine held by Lord Cottenham.

201. Decisions of Lord Cottenham questioned.

202. Corporation may accent or adopt contracts made for it prior to its creation.

203. Effect of such adoption or acceptance.
§ 204. Acceptance or adoption may be express.

205. Stanton v. New York \& Eastern R. R. Co., 59 Conn. 272.

206. Acceptance or adoption by corporation may be inferred from its acts.

207. Taking benefit of contract may be evidence of acceptance or adoption.

208. Circumstances under which it establishes acceptance or adoption.

209. Battelle $v$. Northwestern Cement \& Concrete Pavement Co., 37 Minn. 89.

210. Pittsburg \& Tennessee Copper Co. $v$. Quintrell, 91 Tenn. 693.

211. Acceptance by corporation of subscrintions for shares made before its formation. 
$\$ 212$. Cases in which term ratification used in sense of adoption or acceptance.

213. Paxton Cattle Co. $\imath$. First National Bank of Arrapahoe, 21 Neb. 621 .

214. Distinction between ratification and adoption or acceptance.
§215. English doctrine as to promoter's contracts.

216. Howard v. Patent Ivory Mfg. Co., 38 Ch. D. 156.

217. Corporation cannot adopt or accept ultra vires contracts.

\section{$\S 194$. Contracts made for corporation before it comes into} existence as a rule not enforceable by or against corporation. - Promoters are merely persons who for purposes of their own bring about the formation of the corporation. In assuming to make contracts in its name or behalf before it comes into existence, they do not stand in a relation of agency, and they represent only themselves, inasmuch as a non-existing body caunot have agents. Moreover, it is ordinarily the case that the body of shareholders who ultimately constitute the corporation have no connection with the promoters or their acts, and take their shares on the assumption - and the reasonable assumption - that such contracts as it may be desirable for the corporation to make will be made by it through its known and duly constitnted officers or agents. ${ }^{1}$ Contracts made for a corporation by its promoters prior to its creation are therefore not enforceable by or against the corporation after its organization, ${ }^{2}$

1 Earl of Shrewsbury v. North Staffordshire Ry. Co., 1 Eq. 593, 614.

2 Kelner v. Baxter, I. R. 2 C. P. 174 ; Melhado v. Porte Allegre, New Hamburgh, \& Brazilian Ry., L. R. 9 C. P. 505; Eley v. Positive Assurance Co., 1 Ex. D. 88; Caledonian, \&c. Ry. Co. v. Helensburg, 2 Macq. 391 ; In re Empress Engineering Co., 16 Ch. D. 125 ; In re Northumberland Hotel Co., 33 Ch. D. 16; Franklin Fire Ins. Co. v. Hart, 31 Md. 59 ; Bluehill Academy v. Witham, 13 Me. 403; Munson v. Syracuse, \&c. Ry. Co., 103 N. Y. 58; Lorillard v. Clyde, 122 N. Y. 498; Western Screw \& Mfg. Co. v. Cawsley, 72 Ill. 531; Penn Match Co. v. Hapgood, 141 Mass. 145; Abbott v. Hapgood, 150 Mass. 252 ; Buffington v. Barden, 80 Wisc. 635; Long v. Citizens' Bank, 8 Utah, 104; Moore \&. Handly Harlware Co. v. Tower's IIarlware C'o., 87 Ala. 206; Carey v. Des Moines Coal \& Mining Co., 81 Iowa, 674. 
unless its charter provides otherwise, ${ }^{1}$ or unless, under the doctrines held in this country, they aequire validity through acceptance, adoption, or ratification by the corporation when formed. And this is so, though the promoters become, upon the formation of the corporation, its only shareholders, directors, and officers. ${ }^{2}$

$\S 195$. In Penn Match Co. v. Hapgood, ${ }^{3}$ certain persons agreed to form a corporation and to build a factory for the manufacture of matches, provided they could obtain certain machinery of the defendant, who was a manufacturer of the machinery desired, and the only person from whom it could be obtained. They informed the defendant of the premises, and in the name and for the benefit of the proposed corporation applied to him for the machinery. Thereupon the defendant made contracts in writing to furnish the corporation with the machinery upon specified terms. The corporation was then formed, and a factory built for it, but the defendant refused to furnish the machinery. In

1 Tilson v. Warwick Gaslight Co., 4 B. \& C. 962 ; In re Brampton Ry. Co., 10 Ch. 177; Gent v. Manufacturers' Mut. Ins. Co., 107 Ill. 652; Earl of Shrewsbury v. North Staffordshire Ry. Co., 1 Eq. at p. 615.

${ }_{2}^{2}$ Battelle v. Northwestern Cement \& Concrete Co., 37 Minn. 89. But it has been held that, when persons associated together to carry on a business, contract debts in the course of the business, and afterwards convey the property of the association to a corporation formed by them to prosecute the business, and in which they are the only shareholders, the corporation may be liable in equity for the payment of the debts. "Under such circumstances," said the Court, "the property of no one but those who contracted the debt and were originally liaable would be taken or subjected to the payment of it. The same persons continue the same business, with the same property, with no substantial change except in name. In such a case there is no reason why, in equity, the corporation should not be primarily liable for the debts, as it has succeeded to the property of the association." Paxton v. Bacon Mill, \&c. Co., 2 Nev. 257. See also Bergen v. Porpoise Fishing Co., 41 N. J. Eq. 238.

8141 Mass. 145. 
an action for a breach of the contract brought by the corporation against the defendant, it was held that on the facts stated it could not recover.

$\$ 196$. In Long v. Citizens' Bank, ${ }^{1}$ certain persons agreed to form a corporation to carry on a banking business under the name of the Citizens' Bank. It was arranged that one Barbour should become the Cashier; and when the corporation was organized he was elected as such. Prior to the formation of the corporation, a certificate of deposit was issued, purporting to be a certificate of deposit of the Citizens' Bank for $\$ 1,000$ payable to a person named, and signed by Barbour as Cashier. The plaintiff, being an innocent holder for value, brought suit on the certificate against the corporation. It did not appear that the corporation had received any of the moneys represented by the certificate. It was held that the corporation was not liable.

$\S 197$. In Gooday v. Colchester, \&c. Ry. Co., ${ }^{2}$ a landowner had withdrawn his opposition to a bill for the incorporation of the defendant company, on an agreement that the company when incorporated should buy his lands. The bill passed, but the company did not take his lands. The Court refused to decree specific performance.

$\S 198$. In Buffington $\nabla$. Barden, ${ }^{3}$ the promoters of a corporation, before the corporation came into existence, employed the plaintiff as an architect to prepare plans and specifications for certain buildings which it was designed should be erected for the purposes of the corporation, and agreed that he should be paid a stated sum for his services. The agreement was made in the name of the intended corporation. The plaintiff performed the required services. The corporation was subsequently formed, but

18 Utah, 104.

217 Beav. 132.

880 Wisc. 635 . 
it was not shown that it had availed itself of the labor of the plaintiff. It was held that he could not recover from the corporation.

$\S 199$. By weight of authority corporation cannot ratify contract made for it before its creation. - According to the weight of authority, a contract made in the name and for the benefit of a projected corporation by its promoters, cannot, either at law or in equity, be ratified by the corporation when it comes into existence. Ratification implies an existing person on whose behalf the contract might have been made at the time. There cannot be a ratification of a contract which could not have been made binding on the ratifier at the time it was made because the ratifier was not then in existence. ${ }^{1}$ In Spiller v. Paris Skating Rink, ${ }^{2}$ Malins, V. C., held that the contract might be ratified in equity; but this was overruled by later decisions. ${ }^{3}$ The only thing which results from what is called ratification of such a contract is not the ratification of a contract qua contract, but the creation of an equitable liability depending upon equitable grounds. Thus, when promoters have rendered necessary services prior to the creation of the corporation, of which the corporation avails itself, it may be inequitable for the

1 Kelner v. Baxter, L. R. 2 C. P. 174; Gunn v. London \& Lancashire Ins. Co., 12 C. B. (N. s.) 694 ; Melhado v. Porte Allegre, New Hamburgh, \& Brazilian Railway, L. R. 9 C. P. 503; Abbott v. Hapgood, 150 Mass. at p. 252; Queen City Furniture \& Carpet Co. v. Cravford, 127 Mo. 356 ; McArthur v. Times Printing Co., 48 Minn. 319; Cook v. Tullis, 18 Wall. at p. 338; Pratt v. Oshkosh Match Co., 89 Wisc. 406; Stainsby v. Frazer Metallic Life Boat Co., 3 Daly (N. Y.), 98; Weatherford Mineral Wells \& Northwestern Ry. Co. v. Granger, 86 Tex. 350 .

217 Ch. D. 368.

- In re Empress Engineering Co., 16 Ch. D. 125; In re Northumber land Hotel Co., 33 Ch. D. 16.

4 James, L. J., in In re Empress Engineering Co., 16 Ch. D. 125. 
corporation not to pay the fair value of those services of which it has taken the benefit. ${ }^{1}$

$\S 200$. Doctrine held by Lord Cottenham. - It has also been held in a line of cases decided by Lord Cottenham, that a corporation in whose name and for whose benefit its promoters have, prior to its coming into existence, made a contract with a person touching his property, may be equitably bound not to exercise its legal rights in relation to that property, save in accordance with the requirements of the contract. In Edwards v. Grand Junction Ry. Co., ${ }^{2}$ promoters of a railway company, a bill for the incorporation of which was pending in Parliament, in order to do away with the opposition of the trustees of a turnpike road which it was designed that the railway should cross, agreed with the trustees that the road should be carried over the railway by a bridge fifty feet wide, the width of the road. In consideration of this agreement, the trustees withdrew their opposition, and the bill passed. The company then undertook to construct a bridge only thirty feet wide. An injunction was granted to restrain the company from interfering with the road in any manner other than that specified in the agreement made by the promoters. In Petre v. Eastern Counties $R y$. Co., ${ }^{3}$ the promoters of a railway agreed with the plaintiff, a peer, that, if he would not oppose the bill, the corporation in case the railway should pass through his lands would pay lim before entering them $£ 120,000$. The corporation having been formed, and having the power under the act to condemn the plaintiff's land, pro-

1 In re Hereford Engineering Co., 2 Ch. D. 621 ; In re Empress Engineering Co., 16 Ch. D. 125; In re Dale \& Plant Co., 61 L. T. Rep. 206 (1889).

$21 \mathrm{My} . \&$ Cr. 650.

81 Ry. Cases, 462. 
ceeded to do so. It was enjoined. ${ }^{1}$ See also Stanley v. Chester \& Birkenhead Ry. Co. ${ }^{2}$ In these cases the contract was not enforced by compelling the corporation to take the land or to deal with it according to the contract. The corporation was at liberty to make its entry on the land, or not, as it saw fit; but when it elected to do so, it was lield that, having had the benefit of the consideration of the contract, it was equitably bound not to interfere with the rights of the other party in the land, save in accordance with the terms of the contract. The reasons upon which Lord Cottenham founded his judgment were thus explained by him in a later case: ${ }^{3}$ "The right is not properly speaking a right of contract, but rather arises out of the contract; but the equity is this, that what has subsequently taken place, and the position in which the parties stand, give the party seeking the benefit of the contract a right to the interference of this Court, by virtue of an equity which induces the Court to prevent the company from exercising their legal right, unless upon the terms of adopting and giving effect to the contract which has been entered into by other parties."

$\S 201$. Decisions of Lord Cottenham questioned. - These decisions of Lord Cottenham have been questioned in Preston v. Liverpool, Manchester, \&c. Ry. Co., ${ }^{4}$ Scottish North Eastern Ry. Co. v. Stewart, Caledonian Ry. Co. v.

1 This decision has been severely criticised on the ground that a contract of the nature disclosed, when made with a peer or other legislator, is opposed to public policy. The decision, said Lord Cranworth in Preston v. Liverpool, \&c. Ry. Co., 5 H. L. C. 631, " made everybody start when they heard it." See Green's Brice's Ultra Vires, 2d ed., 581, n. A.

$23 \mathrm{My}$. \& Cr. 773.

8 Greenhalgh v. Manchester, \&c. Ry. Co., 3 My. \& Cr. 784.

45 H. L. Cas. 605. 
Helensburgh, ${ }^{1}$ Earl of Shrewsbury v. North Staffordshire Ry. Co. ${ }^{2}$ On the other hand, their principle was approved by Page-Wood, V. C., in Earl Lindsey v. Great Northern $R y . \mathrm{Co.}^{3}$ and Mr. Brice in his work on Ultra Vires, submits that they still hold good, with this qualification, that it is necessary to except all engagements which are either ultra vires the corporation, or mere bribes to secure the good will of powerful interests, neither of which can, under any circumstances, be enforced against the corporation. ${ }^{4}$

$\$ 202$. Corporation may accept or adopt contracts made for it prior to its creation. - While a corporation cannot, according to the weight of authority, ratify contracts made in its name or behalf before it has acquired life, it may, under what is perhaps the prevailing American doctrine, exercise its power to make contracts, when it comes into existence, by accepting or adopting such contracts. There can be no difference in this respect, it is said, between its making a contract by accepting or adopting an agreement originally made in advance for it, and its making an entirely new contract. ${ }^{5}$ This doctrine seems to rest on the conception that the original contract is in the nature of a

12 Macq. 391.

$21 \mathrm{Eq} .593$.

- 10 Hare, 665. See also Earl Lindsey v. Capper, 3 H. L. C. 293.

- Green's Brice's Ultra Vires, 2d ed., 584.

- Battelle v. Northwestern Cement \& Concrete Pavement Co., 37 Minn. 89 ; McArthur v. Times Printing Co., 48 Minn. 319; Pratt v. Oshkosh Match Co., 89 Wisc. 406; Queen City Furniture \& Carpet Co., 127 Mo. 356; Pittsburg \& Tenn. Copper Co. v. Quintrell, 91 Tenn. 693; Huron Printing \& Binding Co. vi. Kittleson, 4 So. Dak. 520; Gent v. Manufacturers' Ins. Co., 107 Ill. 652; Penn Match Co. v. Hapgood, 141 Mass. 145; Rogers v. New York \& Texas Land Co., 134 N. Y.197; Boomer v. American Spiral Co., 81 N. Y. 468; Swisshelm v. Swissvale Laundry Co., 95 Penn. 367; Morawetz on Corporations, Sect. 549 ; Grand River Bridge Co. v. Rollins, 13 Col. 4 ; Schreyer v. Turner Flouring Mills Co. (Or.), 43 Pac. Rep. 719; Weatherford Mineral Wells \& Northwestern R. R. Co. v. Granger, 86 Tex. 350. 
continuing proposal which, if not withdrawn, the corporation upon its organization may accept. An offer need not be made to an ascertained person; a contract results from the offer when, before withdrawal, it is accepted by an ascertained person. I If acceptance takes place before withdrawal of the offer, there is then a meeting of minds resulting in a mutual contract. Where the parties who made the original contract intended that the corporation when formed should become, or have an opportunity to become, a party to it, it seems entirely reasouable to treat the contract as constituting or including an offer open to the corporation to accept, if it sees fit, when it comes into existence. $^{2}$ If there is such acceptance, it amounts in legal effect, to the making of a new contract, the validity and operation of which must depend upon the common law rules applicable to the making of an original contract. ${ }^{3}$

$\S 203$. Effect of such adoption or acceptance. - Thus, in McArthur v. Times Printing Co., ${ }^{4}$ the promoters of the defendant corporation, which was formed for the purpose of publishing a newspaper, prior to the formation of the corporation made a contract with the plaintiff, in behalf of the contemplated corporation, for his services as an advertising solicitor for the period of one year from October 1, 1889, the date at which it was expected the corporation would be organized. The corporation was not in fact organized until October 16th, but the promoters began the publication of the paper on October 1st, and the plaintiff then entered upon the performance of his duties according to the requirements of the contract, and continued to act

1 Anson on Contracts, 35.

2 Morawetz on Corporations, Sect. 548.

8 McArthur v. Times Printing Co., 48 Minn. 319; Morawetz on Corporations, Sect. 549.

448 Minn. 319. 
until the following April, when he was discharged. In a suit brought by lim against the corporation, the Statute of Frauds was interposed as a defence, on the theory that the corporation had ratified the contract, and that, the ratification relating back to the time when it was made, it was a contract for services not to be performed in one year. But the court held that, the corporation having adopted the contract when it came into existence, such adoption was in legal effect the making of a new contract of the date of the adoption, and that while the contract made by the promoters was not to be performed within one year, the new contract was as a fact to be performed within a year, and so the statute was not applicable.

$\S 204$. Acceptance or adoption may be express. - The acceptance or adoption ${ }^{1}$ by a corporation of contracts made in its name and for its benefit prior to its coming into existence may be formal or express. Thus, in Pratt v. Oshkosh Match Co., ${ }^{2}$ Jones and Wyman were copartners engaged in the manufacture and sale of matches under the name of the Oshkosh Match Company. The plaintiff contracted with the partnership to deliver to it a specified number of feet of boards at a stated price. Subsequently, Jones informed the plaintiff that the defendant corporation was to be formed to take over the business of the partnership, and that the corporation would take the boards; but that owing to changes in the business which would arise from the incorporation, certain alterations of the terms of the order were necessary. The plaintiff agreed to the alterations, and made a new memorandum of sale in his book. The corporation was then organized, and through Jones as its agent ordered the plaintiff to manufacture the boards

1 The terms "adoption" and "acceptance" seem to be interchangeably used in the cases.

289 Wisc. 406. 
according to the terms of the agreement, but with certain modifications. This the plaintiff did. In an action brought by him against the corporation to recover the purchase price of the boards, it was held that on the facts stated he was entitled to recover.

$\S 205$. In Stanton v. New York \& Eastern R. R. Co., ${ }^{1}-$ the promoters of a railroad corporation, previous to its incorporation, entered into a contract with the plaintiff in the name and for the bencfit of the intended corporation, by the terms of which the plaintiff was to purchase at his own expense the lands necessary for the location of the projected railroad, and to convey the same to the corporation when formed, and the corporation was to pay lim therefor by the transfer of a stated number of shares of its capital stock. The corporation was organized, and, by a duly authorized committee of its directors, executed an instrument in writing declaring the contract in question to be "a binding contract upon the parties." The plaintiff devoted much time, both before and after the organization of the corporation, and after the execution of the instrument referred to in carrying out his part of the contract, but the corporation finally abandoned the enterprise. In a suit brought against the corporation by the plaintiff to recorer for his services under the contract, it was held that he was entitled to recover. The liability of the corporation is put by the court on the ground of ratification of the contract; but the facts clearly show an express acceptance. ${ }^{2}$

$\S 206$. Acceptance or adoption by corporation may be inferred from its acts. - The acceptance or adoption may be implied from the acts of the corporation, - "acts from

159 Conn. 272.

2 See also Reichwald v. Commercial Hotel Co., 106 Ill. 439; Davis v. Dexter Butter \& Cheese Co., 52 Kan. 693; McKnight v. Pittsburgh, 91 Penn. 273; Colorado Land \& Water Co. v. Adams, 5 Col. App. 190. 
which you can infer, and from which you ought to infer," that there was an adoption of the contract by the corporation after its formation. This may be inferred from the acceptance by the corporation of property directly delivered to it by the other party to the contract, or received from him through the promoters, to whom it was delivered to be turned over to the corporation when formed; or it may be inferred from the retention by the corporation of the benefit of services rendered under the contract subsequent, or ordinarily prior, to the formation of the corporation. ${ }^{1}$

$\S 207$. Taking benefit of contract may be evidence of acceptance or adoption. - But such inference is not necessarily in all cases to be drawn from the fact that the corporation has benefited by the contract. This circumstance is no more than evidence of acceptance or adoption of the contract. The question upon which the liability or non-liability of the corporation depends is not, Has the corporation had the benefit of the contract? but, Has the corporation adopted the contract and made it its own? If the contract was not made in the name of the intended corporation, but was made on the credit of the promoter, who received goods or money under it, which he subsequently turned over to the corporation when formed, the mere acceptance and retention of the goods or money by the corporation would not amount to an adoption of the promoter's contract. The corporation does not in such case enter into any contract, express or implied, with the person dealing with the promoter, and does not incur any obligation towards that person, by reason of the circumstance that it gets the benefit of what he has done. The principle applicable here may be

1 Under some circumstances, the corporation is not rendered liable for services by retaining the benefit of them. See discussion of liability of corporation to pay for services in obtaining subseriptions for stock, infra. 
illustrated by a decision in a partnership ease. In Emly v. Lye, ${ }^{1}$ a partner drew bills in his own name, and sent them to an agent of the firm in order that he might get them discounted. They were discounted, and the money obtained was remitted by the agent, and was paid to the account of the firm. It was held that the firm was neither liable for the amount of the bills on the bills themselves, nor for their proceeds on the common counts. There was no loan to the partnership; no contract with it; and no liability attached to the firm by the fact that the partner who alone was liable had applied the money after he got it for the benefit of his copartners as well as for the benefit of himself. ${ }^{2}$

$\S 208$. Circumstances under which taking benefit of contract establishes acceptance or adoption of contract. - When, howerer, the contract is made in the name or in behalf of the projected corporation, and is treated as a proposal to such corporation, to be acted upon by it when it comes into existence, then, in the absence of other controlling circumstances, acceptance of benefits under the contract, justifies the inference that the corporation has accepted or adopted it.

$\S 209$. In Battelle v. Northwestern Cement and Concrete Pavement Co., ${ }^{3}$ the plaintiff with two other persons organized the defendant corporation, becoming its only shareholders and its directors and officers. Prior to the formation of the corporation it was agreed that certain property belonging to the plaintiff should be transferred by him to the corporation, when formed, and that in consideration thereof the corporation should assume and pay certain notes which the plaintiff had given in payment of the purchase price of the property when he acquired it. After the

115 East, 7.

21 Lindley on Partnership, 361.

837 Minn. 89. 
corporation was organized, the property in question was transferred by the plaintiff to it, and was accepted and used by it, every member of the corporation having knowledge of the contract under which the corporation acquired the property. It was held that the corporation had accepted and adopted the contract, and was bound to pay the notes according to its requirement. "It is not necessary," said the Court, "that such adoption or acceptance be express, but it may be inferred from acts or acquiescence on the part of the corporation or its authorized agents, as a similar original contract might be shown."

$\S 210$. In Pittsburg \& Tennessee Copper Co. v. Quintrell, ${ }^{1}-$ the evidence showed that one of the incorporators of a mining company contracted with the plaintiff for services before the application for incorporation was made; that after the formation of the corporation, he sent word to the plaintiff to report for work; that when the plaintiff reported, some one else had been employed in his place, but he was promised work if he would wait; that while so waiting he was told by the president of the corporation that he knew of the contract, and was surprised not to find him at work; that later he was given work, but soon after was discharged without fault. It was held that the jury were warranted in inferring that the contract between the plaintiff and the projectors of the corporation had been adopted by the corporation after its organization. ${ }^{2}$

\section{Tenn. 693.}

2 For additional illustrations, see McArthur v. Times Printing Co., 48 Minn. 319; Boomer v. American Spiral Co., 81 N. Y. 468; Grand River Bridge Co. v. Rollins, 13 Col. 4; Rogers v. New York \& Texas Land Co., 134 N. Y. 197; Huron Printing \& Binding Co. v. Kittleson, 4 So. Dak. 520; Swisshelm v. Swissvale Laundry Co., 95 Penn. 367; Schreyer v. Turner Flouring Mills Co. (Or.), 43 Pac. Rep. 719; Brouning v. Great Central Mining Co., 5 H. \& N. 856; Frankfort \& S.T. Co., 6 T. B. Monroe, 427. 


\section{$\$ 211$. Acceptance by corporation of subscriptions for shares} made before its formation. - In accordance with the rule stated, the corporation may avail itself of subscriptions for shares made before its formation, if when it comes into existcnce it accepts the subscriptions, either expressly by formal acceptance or by an issue of a certificate to the subscriber, or impliedly by acts amounting to a recognition of the subscriber in the capacity of a shareholder. Although the subscription is originally in the nature of an open proposition, yet when accepted and acted on by the corporation, before the subscriber retracts it, the right to revoke is lost, and the subscription then becomes an accepted mutual contract, binding upon both the subscriber and the corporation. $^{1}$

$\S 212$. Cases in which term "ratification" used in sense of adoption or acceptance. - There are cases in which the acts

1 Hudson Real Estate Co. v. Tower, 156 Mass. 82 ; Athol Music Hall Co. v. Carey, 116 Mass. 471; Richlieu Hotel Co. v. International Military Encampment Co., 140 Ill. 248; Ashuelot Boot \& Shoe Co. v. Hoit, 56 N. H. 348; Miller v. Wild Cat Gravel Road Co., 52 Ind. 51; Buffalo \& Jamestown R. R. Co. v. Gifford, 87 N. Y. 294; Peninsular R. R. Co. v. Duncan, 28 Mich. 130 ; Penobscot R. R. Co. v. Dummer, 40 Me. 172; Essex Bridge Co. v. Tuttle, 2 Vt. 393; Sanger v. Upton, 91 U. S. 56; Bell's Appeal, 115 Penn. 88; Mahan v. Wood, 44 Cal. 462; Starrett v. Rockland Insurance Co., $65 \mathrm{Me}$. 374. It has been held that where the subscription does not purport to run to the corporation, the corporation cannot enforce it. Lake Ontario Shore R. R. Co. v. Curtis, 80 N. Y. 219. It is held in most of the New England States, contrary to the rule in other jurisdictions, that the corporation cannot enforce a subscription for stock unless the subscriber has expressly promised to pay, or the charter expressly obliges him to do so; and there are cases holding that the subscription once made is irrevocable, and in itself constitutes a contract which upon the formation of the corporation becomes binding. For a review of the law on these points, and a citation and examination of the decisions, see Thompson on Corporations, Sect. 1162 et seq. See also a statement of the law by Professor Collins of the Cornell University Law School, quoted in Cook on Stockholders, 3d ed., Sect. 75. 
of the corporation in relation to contracts made for it before its formation are spoken of, inaccurately, it would seem, as ratification; but the facts disclosed in most of these cases bring them within the rule stated as to acceptance or adoption. ${ }^{1}$ Two cases will serve as illustrations. In Oakes v. Cattaraugus Water Co., ${ }^{2}$ Cowan, who was engaged in organizing a water-works company, and was the principal promoter of the enterprise, in the name of the intended corporation entered into a written contract with the plaintiff to pay him $\$ 1,000$ for his services in securing a right of way and in other matters pertaining to the proposed waterworks. The company was thereafter incorporated, and Cowan became its managing agent, and had full direction and charge of the business. The water-works were constructed, and the plaintiff, at the request of Cowan, rendered services of the character called for by the contract. It was held that it was fairly within the powers of Cowan as managing agent of the corporation to adopt or ratify the contract, and that if he intended in behalf of the corporation, by calling upon the plaintiff to do the things which he had agreed to do in the writing, to adopt and ratify the agreement made before the incorporation, instead of making a new one, there was no good reason why the corporation should not become bound by his action, and that whether or not this was his intention was a question of fact. In a dissenting opinion, Gray, J., pointed out that there could be no ratification of the contract, because it was made before the corporation came into existence. Conceding that a corporation may become obligated by a

1 Stanton v. New York \& Eastern R. R. Co., 59 Conn. 272; Rogers v. New York \& Texas Land Co., 134 N. Y. 197, 211 ; Davis v. Montgomery Furnace \& Chemical Co., 8 So. Rep. 496; Whitney v. Wyman, 101 U. S. 392 ; Grape Sugar \& Vinegar Mfg. Co. v. Small, 40 Md. 395; Bruner v. Brown, 139 Ind. 600.

2143 N. Y. 430. 
contract made for it before its incorporation, through acceptance or adoption, "it should at least appear," he said, " in order to justify a verdict from the facts, that those facts established a knowledge by its agents of its existence and of its terms; or that the benefits, the acceptance of which is relied upon to constitute adoption, were of that nature as to presuppose and charge the company or its agents with kuowledge of a contract with the person from whom derived." But in his opinion, the adoption of the contract could not rest in implication from the mere statement or acts of the interested party who made it, with no evidence to show any knowledge or acquiescence on the part of any other officer or member of the corporation. It is apparent that the point of difference between the majority and minority of the Court in this case was the authority of Cowan to bind the corporation by his acts. Assuming that he had the requisite authority, it was on the facts a question of name and not of substance whether his acts amounted to a ratification or to an acceptance or adoption of the contract; and in the majority opinion, it is said that "in this case ratification and adoption mean the same thing."

\section{§ 213. In Paxton Cattle Co. v. First National Bank of} Arrapahoe, ${ }^{1}$ - the promoters of the Paxton Cattle Company, after executing articles of incorporation, but before the corporation acquired life by the recording of the articles, caused to be executed and delivered to one Meserve, in the name of the corporation, a note in consideration of the sale and in payment for a certain ranch, horses, cattle, and other property, which after the corporation came into existence were delivered to and retained by it, the directors and officers having full knowledge of the facts in relation to the execution of the note. It was held that the assignee of Meserve could recover against the corporation

121 Neb. 621. 
on the note. The Court said: "The conclusion is inevitable, granting the entire want of power on the part of the officers and promoters of the corporation to act as such at the date of the note, that the retaining possession by the corporation after its organization is a ratification of the contract with all its terms and obligations." It seems clear on the facts presented by this case that there was a contract by the corporation, to be implied from its acts, to pay the note according to its terms.

$\S 214$. Distinction between ratification and adoption or acceptance. - Possibly in some of the cases the term "ratification" is employed, not in its strict legal sense, but to express the same meaning which is conveyed by the terms "adoption" and "acceptance." It must be admitted however, that, while in perhaps most cases it is a question not of substance but of name, whether the act obligating the corporation is to be styled ratification or adoption or acceptance, the question may in some circumstances be an important one. Under the theory of ratification, the contract is deemed to have been valid and operative from its inception, the ratification relating back to the moment when the contract was made by the promoters. Under the theory of adoption or of acceptance of a continuing offer, there is no contract until there have been such acts of adoption or acceptance as will fix the rights of both parties. In cases involving a defence based on the Statute of Limitations or on that provision of the Statute of Frauds touching certain contracts not to be performed within one year, the contract might be enforceable under one theory and unenforceable under the other. ${ }^{1}$ This would also be true in cases where the corporation sought to enforce the contract against the resistance of the other party to it. ${ }^{2}$

1 See McArthur v. Times Printing Co., 48 Minn. 319.

2 Penn Match Co. v. Hapgood, 141 Mass. 145. 
§ 215. English Doctrine. - The English doctrine as to promoter's contracts differs from those stated, in that the contract is not treated as a proposal, subject, at any time before it is withdrawn, to acceptance by the corporation when it comes into existence, but, on the contrary, as a contract between the promoter in his individual capacity and the person with whom he deals, to which the corporation cannot become a party by adoption, acceptance, or ratification. If it appears that the promoter and the other party intended to enter into a binding contract, they must be deemed to have contracted in the only way in which they could lawfully contract, - that is, with each other individually. In order to create any obligation as between the corporation and the party with whom the promoter has contracted, there must be a distinctly new contract made between them, although it may be in the same terms as the old contract. It must be supported by a new consideration. The retention of property which has been handed over to the promoter under the old contract, and by him delivered to the corporation, will not suffice. The making of a new contract will not be inferred from the fact alone that the corporation has received and retained the property. ${ }^{1}$ But under some circumstances the corporation may become liable in equity to pay a fair compensation for benefits which it has received. ${ }^{2}$ The fact that a new contract has been made may, however, be inferred from the acts of the parties.

1 Kelner v. Baxter, L. R. 2 C. P. 174; Scott v. Ebury, L. R. 2 C. P. 255; Gunn v. London \& Lancashire Ins. Co., 12 C. B. (N. S.) 694; Melhado v. Porte Allegre, New Hamburgh, \& Brazilian Ry. Co., L. R. 9 C. P. 503; In re Northumberland Hotel Co., 33 Ch. D. 16 . The English doctrine has apparently met with favor in Massachusetts: Abhott v. Hapgood, 150 Mass. 25.?; but compare Penn Match Co. v. Hapgood, 141 Mass. 145. See Winters v. Hub Mining Co., 57 Fed. Rep. 287.

${ }^{2}$ In re Empress Engineering Co., 16 Ch. D. 125. 
$\S 216$. In Howard v. Patent Ivory Manufacturing Co., ${ }^{1}-$ Jordan entered into an agreement with Wysler, who purported to act on behalf of a company about to be formed, to sell certain property to the projected company. The company was formed shortly afterwards, with a memorandum and articles of association containing provisions for the adoption of the agreement by the directors on behalf of the company, with or without modification. At meetings of the directors at which Jordan was present, resolutions were passed adopting the agreement, accepting an offer of Jordan to take payment of part of the purchase money in debentures instead of in cash, and directing that the seal of the company should be affixed to an assignment by Jordan to the company of leasehold property comprised in the agreement, and to debentures to be issued to Jordan. The assignment was executed by Jordan, and sealed by the company; the debentures were issued to him, and the company took possession of the leaseholds and carried on their business thereon. The company was afterwards wound up, and the liquidator took from Jordan an assignment of other property comprised in the agreement. In the winding up, the issue was raised whether the debentures were valid. It was held that there was evidence that a contract had becn entered into by the company with Jordan to the effect of the previous agreement as subsequently modified by the acceptance of debentures instead of cash ; that there was, therefore, at the time when the debentures were issued, an existing debt due from the company, and that they were consequently validly issued. Kay, J., in his judgment, quotes the language of Turner, L. J., in Witson v. West Hartlepool Ry. Co., ${ }^{2}$ that " there is authority for saying that in the eye of this Court it is a fraud to set up the absence of agreement when possession has been given upon the

138 Ch. D. 156.

22 De G., J. \& Sm. 475. 
faith of it;" and that "where possession has been given upon the faith of an agreement, it is the duty of the Court, as far as it is possible to do so, to ascertain the terms of the agreement, and to give effect to it." He also quotes Sir George Jessel, who said in In re Empress Engineering Co., ${ }^{1}$ that the contract between the promoters and the so-called agent for the company was not a contract binding upon the company, nor could it become binding upon it by ratification; but that "it does not follow from that that acts may not be done by the company after its formation which make a new contract to the same effect as the old one."

$\S 217$. Corporation cannot adopt or accept ultra vires contracts. - In stating that a corporation may adopt or accept a contract made in its behalf by its promoters prior to its creation, contracts which are ultra vires the corporation must of course be excluded. And here a suggestion made by Mr. Taylor seems worthy of consideration, namely, that it may be ultra vires for a corporation to adopt acts done before its formation, although the acts are of the same nature as those which the corporation was formed to do. "The true test," says Mr. Taylor, "by which to determine whether the adoption of a given contract is ultra vires the corporation is, not, Would the contract in question have been within the powers of the corporation had it been organized when the contract was made? but, Is it within the powers of the corporation to make the same contract now, supposing it had not been made then? or, Can the company legally carry out that very contract? To illustrate, suppose certain persons, with a view of forming an insurance company, and wishing to find ont for certain how much business a company would get from the beginning, go about making contracts of insurance on behalf of the future company, the insurance to begin at a point of time 
anterior to the formation of the company; the company is afterwards organized. These were contracts which the company could legally have made had it been organized at the time; yet it seems doubtful whether the company could assume those contracts so as to render itself liable for losses which occurred before it was organized. If the promoters had contracted that the company should insure, the insurance to begin with the formation of the company, in that case the company could have adopted and ratified the contracts, for, after its organization, it could legally have made those very contracts." 1 The test proposed seems sound, but the apparent assumption as to the law in the case, put by way of illustration, would seem to be too broad. The company could not ratify the contract, because it was not in existence when the contract was made. On the theory of adoption or acceptance of the contract treated as a continuing offer, the contract could acquire validity only as of the date of adoption or acceptance, and at that date the subject-matter of the insurance not being in existence, the contract would be ultra vires the company, if the truth as to the non-existence of the thing insured were known to the company. But an insurance company has power to make a retrospective contract of insurance, and the policy may by its terms relate back so as to cover a loss which happened anterior to the date of the policy. ${ }^{2}$ An insurance company might issue a policy of insurance on a vessel which some months prior thereto had sailed on a whaling voyage to the Pacific Ocean. If the policy were written to cover a loss during the entire voyage, it is not conceived that, in the absence of misrepresentation or concealment, the fact that the loss occurred prior to the formation of the insurance company would constitute a defence to a suit on

1 Tavlor on Corporations, 2d ed., p. 87, note.

2 Paddock v. Franklin Ins. Co., 11 Pick. 227. 
the policy. The company could, therefore, in the case put by Mr. Taylor, have made the very contract stated by him, and having the power to make it, it follows that it would have the power to adopt such a contract made in advance for it, provided that it did not know that the loss to be insured against had already occurred.

Article II. - Liability of Corporation to pay its Promoters, or Persons employed by them, for Services and Expenses incident to its Formation.

$\S 218$. Statutory liability.

219. Liability under the English Companies Acts.

220. Melhado $v$. Porte Allegre, New Hamburgl, \& Brazilian Ry. Co., L. R. 9 C. P. 503.

221. Liability on quantum meruit.
$\S 222$. Doctrines held in this country as to liability of corporation.

223. Liability to pay for services and expenses in obtaining subscriptions for shares.

224. Doctrine held in Vermont and New Hampshire.

$\S 218$. Statutory liability. - In the case of corporations created by a special act of the legislature, the act sometimes contains a clause that the expenses, costs, and charges incidental and preparatory to the formation of the corporation shall be paid by the corporation after it is organized. This creates a legal liability on the part of the corporation to pay the proper expenses of obtaining its charter. It enables the promoters who have performed necessary services, or incurred proper expenses, in the work of formation, to recover from the corporation. There is in such cases a statutory obligation of which the person named can take the benefit, - an action for debt on a statute being a well known old form of action at common law. ${ }^{1}$ But those only who are acting directly for the proposed corporation, and who have no other pay-

1 Per Lindley, J., in In re Rotherham Alum \& Chemical Co., $25 \mathrm{Ch}$. D. at p. 111 ; Scott v. Lord Ebury, L. R. 2 C. P. at p. 264. 
master to look to, are entitled to recover payment from the corporation when it is formed. Those who are employed by any other person for hire or reward to do the work must look for payment to the person who employed them. ${ }^{1}$

§ 219. Liability under English Companies Acts. - The power, without imposition of liability, to pay for such services and expenses may be given to the corporation by statute. Thus, in the English Companies Acts, it is provided that the directors " may pay all expenses incurred in getting up and registering the company." 2 In cases arising under those acts, it has been held that the fact of incorporation does not entail upon the corporation a liability at law to pay for these preliminary services and expenses. The corporation, having the power, may of course pay them if it sees fit to do so; but a provision in the articles of association that the corporation shall pay or shall adopt an agreement for payment for services to be rendered in the formation of the corporation is not enforceable against the corporation, for it cannot be taken advantage of by an outsider, nor by a member to secure benefits outside his rights as a member. ${ }^{3}$

$\S 220$. In Melhado v. Porte Allegre, New Hamburgh, \& Brazilian Ry. Co., ${ }^{4}$ - it was held that promoters who have incurred necessary preliminary expenses in the establishment of the company, cannot recover the same from the company. Lord Coleridge, stating that he had reluctantly come to the conclusion that no such action would lie,

1 In re Skegnors \& St. Leonards Tramway Co., 58 L. J. Ch. 737, in which the cases on the subject are cited and considered.

2 Companies Act, 1862, Table A, paragraph 55.

${ }^{3}$ In re Rotherham Alum \& Chemical Co., 25 Ch. D. 103; Melhado v. Porte Allegre, New Hamburgh. \& Brazilian Ry. Co., L. R. 9 C. P. 503; Browne v. La Trinidad, 37 Ch. D. 1; Eley v. Positive Assurance Co., 1 Ex. D. 88.

4 L. R. 9 C. P. 503. 
observed: "It does seem just, in general, if a company takes the benefit of the work and expenditure by which its existence has been rendered possible, and voluntarily comes into existence on the terms that it shall be liable to pay for such work and expenditures, that a cause of action should be given. I can find, however, no legal principle upon which such an action can be maintained. It appears to me that there is no contract between the plaintiffs and the defendant. The doctrine of ratification is inapplicable, for the reasons given in the judgment in Kelner v. Baxter." 1

$\S 221$. Liability on quantum meruit. - The corporation, it has been held, however, may be liable in equity on a quantum meruit. ${ }^{2}$ This enables the promoters or persons employed by the promoters, and looking exclusicely to the projected corporation for payment, to recover from the corporation fair compensation for services rendered and expenses incurred in bringing it into existence. But when persons perform work for the promoters in the formation of the corporation, for payment of which they look to the promoters, they cannot afterwards hold the corporation on the ground that it has had the benefit of their work. As a general rule, it is incquitable for a person not to pay for the services of which he has taken the benefit; but this is not true when the work was done for a third party dealing with such person. Thus, in In re Rotherham Alum \& Chemical Co., ${ }^{3}$ Mycrofts promoted a company in order that he might sell certain property to it. He employed Pease as a solicitor in its formation, and Pease, on Mycroft's retainer, rendered necessary services in the incorporation

1 L. R. 2 C. P. 174.

${ }_{2}$ In re Hereford \& South Wales Wagon Co., 2 Ch. D. 621 ; In ve Empress Engineering Co., 16 Ch. D. 125.

$325 \mathrm{Ch}$. D. 103. 
of the company. In the winding up, Pease presented a claim for services as solicitor, which was disallowed as to all items incurred before the formation of the company, it not appearing that the company had agreed to pay them. It having been contended that the company was liable on the ground, among others, that it had taken the benefit of the services, Lindley, L. J., observed: "It is said that Mr. Pease has an equity against the company because the company has had the benefit of his labor. What does that mean? If I order a coat and receive it, I get the benefit of the labor of the cloth manufacturer; but does any one dream that I am under any liability to him? It is a mere fallacy to say that because a person gets the benefit of work done for somebody else he is liable to pay the person who did the work." 1

222. Doctrines held in this country as to liability of corporation. - In this country, so far as the corporation is concerned, in the absence of statutory obligation, there is some authority for the proposition that services rendered or expenditures made in bringing the corporation into existence are to be taken as voluntary, no promise by the corporation to pay for them being implied from acceptance of the benefit by the corporation, or created by any contract made by the promoters in the name of the intended corporation. ${ }^{2}$ But the subject has not received much consideration. The doctrine has been put forward in Pennsylvania, that the corporation, when formed, is liable for services rendered or money expended in procuring the charter, provided such services were rendered or expense incurred under an agreement for payment authorized by a majority

1 See also Perry v. Little Rock \& W. S. R. Co., 44 Ark. 383, 395.

2 Taylor on Corporations, Sect. 86; Bishop on Contracts, Sect. 221 ; Hall v. Vermont \& Mass. R. R. Co., 28 Vt. 401 ; Marchand v. Loan \& Pledge Association, 26 La. Ann. 389. 
of the persons associated together for incorporation. ${ }^{1}$ The theory seems to be that the corporation, by taking the benefit of the agreement made by its corporators or promoters, thereby ratifies the agreement. But, as has been observed by a learned writer, if the corporation ratifies the agreement, it is not a case of being bound by the act of a majority of the promoters or corporators. ${ }^{2}$ In Kentucky, the same conclusion has been reached as in Pennsylvania, but on the theory of estoppel, instead of that of ratification. In Morton v. Hamilton College, ${ }^{3}$ the promoters of an incorporated college assumed an obligation to pay the interest on a subscription to a fund for the purchase of property for the college. It was necessary to do this in order to obtain the subscription, and it was done at the request of some and with the consent of all of those who constituted a committee to organize the college and raise the necessary moneys, and with the understanding that the corporation, when formed, should save the promoters harmless. In an action brought by the promoters against the corporation to recover the amount of interest which they had been compelled to pay, and which went into the fund used in buying the college property, it was held that the corporation was estopped from claiming that the committee had no power to bind it by an agreement made prior to its coming into existence.

The question of the power of a private corporation, in the absence of provision therefor in the enabling act, to devote any of its funds to paying for the preliminary services and expenditures incident to its formation, does not seem to

${ }^{1}$ Bell's Gap R. R. Co. v. Christie, 79 Penn. 54; Tift v. Quaker City Nat. Bank, 141 Penn. 550.

2 Promoters' Contracts, by Austin Abbott, in 1 Amer. \& Eng. Corp. Cas., Anno. 1.

338 S. W. Rep. 1. 
have been raised in any of the cases. But it has been held that a town has no authority to appropriate money for the payment of expenses incurred by individuals, prior to its corporate existence as a town, in procuring the passage of its act of incorporation, the act not authorizing the payment of such expenses. ${ }^{1}$ If the corporation has power to pay for the services and expenses necessary to bring it into existence, and actively takes the benefit of such services and expenditures by entering upon the corporate enterprise, and if as a fact the work was not done or the expense incurred gratuitously, or upon the credit of a third party, but with the expectation that the corporation, when formed, would make payment, it would scem that the corporation. ought in equity to be holden for payment to a fair and reasonable amount. ${ }^{2}$

$\S 223$. Liability to pay for services and expenses in obtaining subscriptions for shares. - While it seems just that the corporation should reimburse those persons who have paid the necessary and reasonable expenses of its creation, services performed or expenditures made in procuring subscriptions for stock ordinarily stand on a different footing. In some cases, it is true, as under the National Banking Act, that the subscription of the capital stock is a condition precedent to the existence of the corporation. But in many cases the procurement of subscriptions may follow the organization of the corporation after it comes into existence. As applied and limited to the latter cases, the doctrine held by some courts would seem to be sound, namely, that if expense is to be incurred by the corporation in obtaining subscriptions for its stock, it should only be by the authority of its duly constituted officers. ${ }^{3}$ "It is

1 Frost v. Belmont, 6 Allen, 152.

${ }^{2}$ In re Hereford v. So. Wales Wagon Co., 2 Ch. D. 621 ; In re Empress Engineering Co., $16 \mathrm{Cl}$. D. 125.

8 Rockford, Rock Island, \& St. Louis R. R. Co. v. Sage, 65 Ill. 328; 
soon enough," it lias been said, "for corporate bodies to enter into contracts encumbering their property, when they are duly organized according to their charters, and have their chosen and impartial directors to conduct their' business." 1 To bring a corporation into existence, the promoters must necessarily take action; but there is no reason in the cases referred to why the promoters should be permitted to usurp the power of the directors to determine what expense shall be incurred in procuring subscriptions for the capital stock; and that is in effect what it comes to if the directors cannot accept subscriptions which have been influenced by the promoters, or by persons employed by the pronoters, without thereby placing the corporation under obligation to pay such persons or the promoters for their services.

$\S 224$. Doctrine held in Vermont and New Hampshire. Contrary to this view, it has been held in Vermont and New Hampshire that when the promoters of a corporation have, after its charter but prior to its organization, agreed with a person that he shall be paid by the corporation for his services in obtaining subscriptions for shares, and subscriptions are thus procured, which are accepted by the corporation, the benefits must be taken cum onere, and the corporation is liable to pay for the services rendered according to the contract. ${ }^{2}$ This view has been much criticised. Judge Redfield refers to it " as of too great laxity and too susceptible of abuse to afford a safe guide in these lax times, when erery possible avenue to corruption is sure to find some one desperate to enter." 3 May it not also be said that it rests upon a fallacy? The theory is that all New York \& New Haven R. R. Co. v. Ketchum, 27 Conn. 170; Western Screw \& Mfg. Co. v. Cousley, 72 Ill. 531; Stowe v. Flagg, 72 Ill. 397 ; Franklin Ins. Co. v. Hart, 31 Md. 59.

1 New York \& New Haven R. R. Co. v. Ketchum, 27 Conn. 170.

2 Low v. Conn. \& Passumpsic R. R. Co., 45 N. H. 370 ; Hall v. Vermont \& Massachusetts R. R. Co., 28 Vt. 401.

${ }^{3} 1$ Redfield on Railways, Sect. 14, note. 
burdens must be taken with the benefit. But this is not always true. In receiving and accepting a subscription for shares, the corporation deals solely with the subscriber. It takes his money and delivers to him therefor a certificate of membership. Clearly the corporation, not being bound by the contracts of its promoters, has a right to deal with any person who may come forward as a subscriber, unhampered by any terms save those agreed upon between it and the subscriber. It may get the benefit of labor performed by some third person in inducing the subscriber to apply to the corporation for shares. But that person, in the absence of employment or authority or an agreement for payment by the corporation, has no more right to claim payment from the corporation than has the manufacturer who has furnished cloth to a tailor to claim payment for his cloth from a person buying a coat from the tailor. The purchaser of the coat gets the benefit of the labor of the cloth manufacturer, yet no one would claim that its acceptance rendered him liable therefor to the manufacturer. By accepting the coat, he becomes liable merely to pay the purchase price to the tailor. The corporation, by accepting a subscription becomes bound to admit the subscriber to membership, and that is all. In these cases there is no privity of contract save between the contracting parties. The third party is not brought into privity by the acceptance of the subscription in the one case, or by the acceptance of the coat in the other. If $A$. without authority, in the name and for the benefit of B., orders goods of C., acceptance of the goods by B. is a ratification or adoption of the contract to pay $\mathrm{C}$. for them, but it is not a ratification or adoption of an unanthorized agreement made by a stranger to $B$. that $B$. shall pay $A$. for his trouble in the matter. ${ }^{1}$

1 See Weatherford Mineral Wells \& Northwestern R. R. Co. v. Granger, 86 Tex. 350 . 


\section{CHAPTER XI.}

RIGHTS AND LIABILITIES OF PROMOTERS UNDER CONTRACTS MADE BY THEM, OR BY THEIR CO-PROMOTERS, IN BEHALF OF OR FOR THE BENEFIT OF A PROJECTED CORPORATION. - CONTRACTS BETWEEN PROMOTERS.

$\$ 225$. Promoter not liable on contract made in name of intended corporation, unless he agreed to be so.

226. Presumption as to intent of parties.

227. Landman $v$. Entwistle, $7 \mathrm{Ex}$. 63i2.

228. On written contract question of intent is for the Court. - Kelner $v$. Baxter, L. R. 2 C. P. 174.

229. Scott v. Ebury, L. R. 2 C. P. 255.

230. Promoter usually not liable on contract made in name of corporation. - Liable for misrepresentation as to existence of corporation.

231. Effect of adoption by corporation of contract on which credit was given to promoter.

232. Abbott $v$. Hapgood, 150 Mass. 248.

233. Promoters not prima fucie partners.

234. English cases as to liability of promoters on contracts made by co-promoters.

235. Ordinarily promoter not liable from allowing his name to appear in prospectus or signing articles of incorporation, if he does not act in undertaking.

236. Statements in prospectus in which promoter allows his name to be used may impose liability upon him.
\$ 237. When promoter has acted in undertaking, question for jury whether he has authorized co-promoters to bind him.

238. Riley $v$. Packington, L. R. 2 C. P. 536.

239. Promoter's liability on contract made before he became a promoter. - Effect of admission of liability.

240. To hold promoter, credit must have been given to him.

241. Joint liability of promoters. - Effect of release of one.

242. Right of promoter to indemnity from co-promoters.

243. Right of promoter to contribution from co-promoters.

244. Batard v. Hawes, 2 El. \& B. 287.

245. In absence of agreement, promoter cannot enforce payment for services from co-promoters.

246. No contract between promoters to go forward implied from their association together.

247. Legality of agreements between promoters as to formation of corporation and its future management and control.

248. Agreement between promoters restricting sale of their stock. 
$\S 225$. Promoter not liable on contract made in name of intended corporation unless he agreed to be so. - As the promoter in contracting in the name and in behalf of the intended corporation assumes to act as its agent, the rules applicable to persons who contract professedly as agents must be followed in determining the rights and liabilities of the promoter under such a contract. According to the weight of argument and authority, one who is known to be professedly or really acting as an agent, and who discloses his real or avowed principal, and contracts in the name of such principal, cannot, although he acts without authority, or has no principal, be made liable on the contract unless he expressly or impliedly agreed to be so. ${ }^{1}$ Whether he is to be personally bound on the contract is always a question of the intention and understanding of the parties. The fact that a binding contract does not result, because it turns out that the professed agent has no principal who can be holden, as was contemplated, is not a reason for the creation by judicial construction of a different contract which neither of the parties intended to make. ${ }^{2}$

$\S 226$. Presumption as to intent of parties. - The presumption is that one contracting avowedly as an agent for a principal competent to act does not intend and is not taken to bind himself. But when one assumes to represent a principal who has no legal existence or status,

1 Howard v. Yunker, 83 Ill. 208; Hersey v. Tully (Col. 1896), 44 Pac. Rep. 854; Johnson v. Smith, 21 Conn. 627; Hall v. Crandall, 29 Cal. 567; Stetson v. Patten, 2 Me. 35S; Weare v. Gove, 44 N. H. 196; White v. Madison, 26 N. Y. 117; Cole v. O'Brien, 34 Neb. 68; Farmers' Coöperative Trust Co. v. Floyd, 47 Ohio St. 525; McCurdy v. Rogers, 21 Wisc. 199 ; Randall v. Taimen, 18 C. B. 793. Contra: Terwilliger v. Murphy, 104 Ind. 32; Andrew v. Tedford, 37 Iowa, 314; Solomon v. Penoyer, 89 Mich. 11; Bay v. Cook, 22 N. J. L. 343; Ennis Cotton Oil Co. v. Burks (Tex. 1897), 39 S. W. Rep. 966.

2 Whitney v. Wyman, 101 U. S. 392; Higgins v. Senior, 8 M. \& W. 834 ; Johnson v. Smith, 21 Conn. 627. 
the presumption is the other way, for in the absence of evidence to show the contrary, it is unreasonable to suppose that the person with whom the alleged agent contracts consents to look only to a non-existent person. ${ }^{1}$ This presumption, however, may be overcome, for a person dealing with one assuming to act for an intended corporation might expressly or impliedly agree to look only to the future corporation, taking the risk of its coming into existence and adopting the contract made in advance for it, ${ }^{2}$ or it might be stipulated that the agent should in no event be personally liable. ${ }^{3}$ In such cases, it would seem to follow that the agent, not being bound, could not enforce the contract, unless he had given the other party a valid consideration for his promise. Applying these rules to the case of the promoter who has made a contract in the name and behalf of an intended corporation, the rights and liability of the promoter under the contract will depend upon the questions of fact whether credit was given to him or to the inchoate corporation, or whether he expressly or impliedly agreed to be bound. If the contract was oral, it is for the jury to determine the intention and understanding of the parties. ${ }^{4}$

$\S 227$. In Landman v. Entwistle, ${ }^{5}$ - the plaintiff brought an action to recover for his services as engineer of a projected railway company against the defendant, who was one of the provisional committee of the company. It appeared that at a meeting of the committee, at which the plaintiff was present, it was resolved "that the provisional committee disclaim the intention of taking on

1 Eichbaum v. Irons, 6 Watts \& Serg. 67.

2 Higgins v. Hopkins, 3 Ex. 163; Rennie v. Clarke, 5 Ex. 292; Landman v. Entwistle, 7 Ex. 632 ; Case Mfg. Co. v. Soxman, 138 U. S. 431.

8 Shoe \& Leather Nat. Bank v. Dix, 123 Mass. 148.

4 Higgins v. Hopkins, supra.

57 Ex. 632. 
themsclves any personal responsibility as regards the expenses incurred or to be incurred in or about the company, and that no such responsibility shall attach to them." At another meeting, at which the plaintiff was also present, a resolution was passed which contained a statement that the plaintiff had said "that he would make no claim for his services until there should be sufficient funds of the company to meet any demand he might be entitled to make." - The plaintiff stated in a letter that " he never understood that, unless the project was successful, the engineers were to abandon all claim; but he did understand that the individuals comprising the committee were not to be held personally liable." At a subsequent meeting of the committee it was resolved "that the committee bind themselves to be answerable to the extent of $£ 1,000$, to be applied to engineering and surveying purposes." The scheme was abandoned, and deposits to the amount of $£ 4,168$, which had been received by the committee, were returned to the shareholders. It was held that the defendant was not responsible, the contract being that the plaintiff should be paid out of such funds as could be properly applied in satisfaction of his claim, and there were no funds of that description.

$\S 228$. On written contract question of intent is for Court. -If the contract is in writing, it is for the Court to pass upon the question of the intent of the parties, and in construing a written contract of this nature parol evidence of the real intent of the parties is inadmissible. The intent must be drawn from the language employed. No parol evidence can exclude personal liability in the promoter, if the written document itself makes him liablc. ${ }^{1}$ If the promise is made in the name of the intended corporation, and exclusively as its contract, and is accepted as such, the

${ }^{1}$ Higgins v. Senior, 8 M. \& W. 834. 
promoter cannot, under what would seem to be the true rule, be held liable upon it. If, on the other hand, the contract contains apt words to bind the promoter personally, he will be held on the contract, although he may sign as an agent. ${ }^{1}$ Thus, in Kelner v. Baxter, ${ }^{2}$ the plaintiff was a wine merchant and the proprietor of the Assembly Rooms at Gravesend. It was proposed that a company should be formed under the name of the Gravesend Royal Alexander Hotel Company, Limited, to purchase the plaintiff's premises and stock, and carry on a hotel business. The plaintiff was to be the manager, and the defendants directors of the proposed company. Pending the negotiations, the business was carried on by the plaintiff, and for that purpose additional stock was purchased by him, as to which the following agreement was entered into:-

To John Dacier Baxter, Nathan Jacob Calisher, and John

Dales, on behalf of the proposed Gravesend Royal Alexander Hotel Company, Limited,

Gentlemen, - I hereby propose to sell the extra stock now at the Assembly Rooms, Gravesend, as per schedule hereto, for the sum of $£ 900$, payable on the 28th of February, 1866.

(Signed)

John Kelner.

Then followed a schedule of the stock to be purchased, and at the end was written as follows:-

To Mr. John KeLner,

Sir, - We have received your offer to sell the extra stock as above, and hereby agree to and accept the terms proposed.

(Signed)

J. D. BAXTER,

N. J. Calisher,

J. Dales,

On behalf of the Gravesend Royal Alexander Hotel Company, Limited.

1 Hall v. Crandall, 29 Cal. 567 ; Johnson v. Smith, 21 Conn. 627; Hurst v. Salisbury, 55 Mo. 310.

2 L. R. 2 C. P. 174. 
The goods were handed over to the representatives of the proposed company, and were consumed in the business. Subsequent to the purchase of the goods, the company was incorporated, but collapsed before the money was paid. It was held that the defendants were personally liable on their agreement, as for goods sold and delivered; that no subsequent ratification by the company could relieve them from that liability without the assent of the plaintiff ; and that parol evidence was not admissible to show that personal liability was not intended. "Construing the document ut res magis valeat quam pereat," said Willes, J., "we must assume that the parties contemplated that the persons signing it would be personally liable. Putting in the words, ' on behalf of the Gravesend Royal Alexander Hotel Company,' would operate no more than if a person should contract for a quantity of corn ' on behalf of my horses." "

$\S 229$. In Scott v. Ebury, ${ }^{1}$ - one Jeyes, acting as the solicitor and secretary of a projected railway company, by the authority of the promoters, and by means of a check signed by two of them, obtained from the plaintiff an advance of $£ 500$, to be applied in payment of parliamentary fees, upon the agreement contained in the following letter addressed to the plaintiff :-

I have to request that you will allow the directors of the Rickmansworth, Amershan, and Chesham Railway to draw to the extent of $£ 1,000$, to be repaid out of the calls on shares.

The $£ 1,000$ was placed to the credit of the company in an account in the plaintiff's books, and $£ 500$ was drawn therefrom. An act authorizing the construction of the railway subsequently passed, the promoters being named therein as the first directors, and at a directors' meeting it

1 L. R. 2 C. P. 255. 
was resolved that the acts of Jeyes should be adopted and confirmed. No shares were allotted or calls made, and the undertaking was not proceeded with. It was lield that the advance was made upon the personal responsibility of those who signed the click, and that the subsequent adoption of their acts by the directors did not alter their position. On the part of the defendants, it was contended that the loan was not to them personally, but to the company, to be repaid out of the funds of the company when funds should be obtained by means of calls. As to this contention, Willes, J., said: "The true explanation of the expression of the letter, "to be repaid out of calls on shares,' is this. Parties who embark in schemes like this do not always contemplate the true future. They assume that everything will go on according to their hopes and expectations, and provide for what shall be done in that event, without regarding the possibility of failure. Here, they provided for the case which they hoped for, and in that case stipulated that the money should be repaid out of calls. Would any person have advanced the money upon an agreement such as the defendants contend this to be? Clearly not. Suppose a farmer were to borrow money to be repaid when he sold his crop of hay, and after the lapse of a reasonable time for effecting a sale the ricks were burnt down, would he be excused from repaying the loan? Or, suppose goods in course of transit to be sold, to be paid for on arrival, and they are lost on the way, could it be contended that the non-arrival of the goods would be an answer to an action for the price? I need hardly say it would not. In each of these cases, it is simply a provision for the time of payment."

$\S 230$. Promoter making contract in name of corporation usually not liable on the contract. - But may be liable for misrepresentation as to existence of corporation. - As has been 
said, when the promise has been made in the name of the intended corporation, and exclusively as its contract, and has been accepted as such, the promoter eannot, under what would appear to be the true rule, be held liable upon it. The mere fact that he does not bind his assumed principal cannot make him responsible upon the contract; but he may be liable in damages for misrepresentation, by holding himself out as an agent for an existing corporation, when in fact the corporation named as such is not in existence. ${ }^{1}$ The reason why the promoter should not be made personally liable on such a contract is, as it has been well put in the case of an agent, this: "The man whom he induced to enter into the contract did not contemplate him as the other party to it, or look to any one but the alleged principal. The remedy should be, as it is, for misrepresentation, innocent or fraudulent." 2 In order to sustain an action for damages against the promoter, it is obviously essential to show that the nonexistence of the corporation was not known to the person dealing with the promoter; ${ }^{3}$ and that such person was misled to his injury. If he knew that the corporation was not in existence he could not have been deceived, and if the eorporation should subsequently come into existence and adopt the contract the element of damage might be wanting. It is immaterial whether the promoter made the representation as to the existence of the corporation innocently or fraudulently. In the former case, his liability

1 Jefts v. York, 10 Cush. at p. 395; Bartlett . Tucker, 104 Mass. 337; Gilmore v. Bradford, 82 Me. 547; McCurdy v. Rogers, 21 Wisc. 199; Patterson v. Lippencott, 47 N. J. L 457; Duncan v. Niles, 32 Ill. 532 ; Johnson v. Smith, 21 Conn. 627; Hall v. Crandall, 29 Cal.567. Contra, Keener v. IIarrod, 2 Md. 63 ; Lewis v. Tilton, 64 Iowa, 220 ; Lagrone v. Timmerman (S. C. 1896), 24 S. E. Rep. 290.

2 Anson on Contracts, 344.

3 Jefts v. York, 10 Cush. at p. 395. 
may be put on the ground of the breach of an implied warranty, ${ }^{1}$ or on the ground of liability for an innocent misrepresentation, as an exception to the general rule of law that an action for damages will not lie against a person who honestly makes a misrepresentation which misleads another. ${ }^{2}$ In the latter case, his liability is for deceit.

$\S 231$. Effect of adoption by corporation of contract on which credit was given to promoter. - If it appears that credit was given to the promoter, and that he is personally bound on the contract, then the adoption or ratification of the contract by the corporation, when formed, would not free him from liability without the creditors' assent. In such case the creditor could elect whether to sue the corporation or the promoter; but it would seem that he could not hold both. ${ }^{3}$ If the promoter should be held, under such circumstances, the corporation would probably be impliedly bound to indemnify him, inasmuch as it would be entitled to the full benefit of the contract against the promoter, who would stand in such respect in the position of its agent. If the promoter is held to the duties and liabilities of an agent under a contract adopted or ratified by the corporation, he should have the rights of an agent. ${ }^{4}$ If credit was not given to the promoter, then he would be free from liability, whether the corporation did or did not subsequently adopt or ratify the contract; and in such case, not being bound himself, and the contract having been made for and on the credit of the intended

1 Collen v. Wright, 7 El. \& Bl. 301 ; 8 El. \& Bl. 647.

2 Per Lindley, J., in Fairbanks Ex'rs v. Humphreys, 18 Q. B. D. 62.

${ }^{3}$ Queen City Furniture \& Carpet Co. v. Crawford, 127 Mo. 356; Meacham on Agency, Sect. 698 ; Case Mfg. Co. v. Soxman, 138 U. S. 431. Contra, Ennis Cotton Oil Co. v. Burks (Tex. 1897), 39 S. W. Rep. 966.

4 Taylor on Corporations, Sects. 82, 85. 
corporation, he could not enforce it, unless he had given the other party a valid consideration for his promise. But if the contract was made with the promoter personally, he may enforce it.

§ 232. In Abbott v. Hapgood, ${ }^{1}$ - the plaintiffs had agreed to form a manufacturing corporation, under the name of Penn Match Company, Limited, if they could obtain certain machinery from a firm which alone could furnish it; and, for the purpose of carrying out the agreement, and in the name and for the benefit of the projected corporation, applied therefor, informing the firm that the organization of the corporation would be proceeded with and a factory built for it only in case they could make a contract with the firm for the machinery. The firm agreed "to furnish the Penn Match Company, Limited, with the machinery" at a price stated, but subsequently refused to deliver it, whereupon an action was brought against the firm in the name of the projected corporation to recover damages for such refusal, in which judgment was rendered for the defendants. Subsequently the corporation was fully organized, the factory was built for it, and it started in business. Upon the facts reported, the Court was of opinion that the defendants as well as the plaintiffs must have understood that the corporation was only projected, that the plaintiffs, acting jointly as individuals, constituted the only party who could contract with the defendants in the manner proposed, that it was evident that both parties intended to enter into binding contracts, and that the plaintiffs assumed the name "Penn Match Company, Limited," as that in which they chose to do business in reference to the projected company until their organization should be completed, and they should turn over the business to the new company, which would be composed of themselves in a new relation. 
The trial court ordered a verdict for the defendants, and reported the case for the determination of the appellate court, which set aside the verdict and ordered a new trial. The plaintiffs were allowed to amend the declaration so as to state the contract truly, that is, by setting out their own agreement to take and pay for the machinery which constituted the consideration for the agreement made by the defendants.

$\S 233$. Promoters not prima facie partners. - Co-promoters are not, as such, partners. A mere agreement to form a partnership in the future does not create a present partnership. A fortiori, an agreement by persons simply to organize a corporation does not constitute such persons partners. Nor are promoters prima facie each other's agents. In order to render a promoter liable for the acts of his co-promoters, it must be shown as matter of fact that the former authorized the latter to bind him, or held them out as so authorized. In an action against a promoter on a contract not made personally by him, but by a co-promoter, the point to be decided is whether the latter was the former's agent, or was held out by him as his agent, for the purpose of making the contract, and made it as such. The agency or holding out, as in any other case where such question is in issue, may be implied from words or conduct. ${ }^{1}$

$\S 234$. English cases as to liability of promoters on contracts made by co-promoters. - In England, the preliminary

1 Reynell v. Lewis, Wylde v. Hopkins, 15 M. \& W. 517; Capper's Case, 1 Sim. x. s. 178; Forrester v. Bell, 10 Ir. Law Rep. 555; Norris v. Cottle, 2 H. L. Cas. 647; Hutton v. Thompson, 3 H. L. Cas. 161; Bright v. Hutton, 3 H. L. Cas. 348; Wood v. Argyll, 6 M. \& G. 928; Newton v. Belcher, 12 Q. B. 921 ; Rutherford v. Hill, 22 Or. 218; Hornblower v. Crandall, 78 Mo. 581 ; Ward v. Brigham, 127 Mass. 25. Compare Dole v. Wooldredge, 135 Mass. 140 ; Sproat v. Porter, 9 Mass. 300. It was at one time held otherwise in England: Holmes v. Higgins, 1 B. \& C. 74 ; Lucas v. Beach, 1 M. \& G. 417 ; Hutton v. Uphill, 2 H. L. Cas. 674 ; but these cases are no longer law. 
work of getting up a company is usually, it would appear, performed under the direction of a provisional committec or a managing committee of the intended company, consisting of the promoters or of others selected by them. The reports contain many cases presenting the question of the liability of a particular member or members of such a committee to tradesmen and others for work performed or materials furnished in the formation of the company, at the request, not of the defendants personally, but of other members or of the secretary or solicitor of the committee. As the existence of an authority proceeding from the member sought to be charged to others to bind him is a question of fact, to be determined by a jury, more or less apparent conflict will be found in these cases. ${ }^{1}$ But certain general rules may be deduced from them.

$\S 235$. Ordinarily promoter not liable from allowing his name to appear in prospectus, or signing articles of incorporation, if he does not act in undertaking. - A committeeman, who merely allows his name to appear in a prospectus, which states the names of the committee, and nothing more from which liability on his part might be inferred, and who does not act with relation to the undertaking, incurs no liability for work or supplies furnished at the request of other members, or of the solicitor or secretary. The mere announcement that several persons are acting together to organize a company does not justify the inference that one has authorized the others to pledge his credit in the matter. ${ }^{2}$ Thus, in the leading cases of Rey-

1 For example, in Wood v. Argyll, 6 M. \& G. 928, and in Lake v. Argyll, 6 Q. B. 477, the same acts were relied on to show that the defendant had authorized others to pledge his credit. In the first case the verdict was for the defendant, in the last for the plaintiff, and in each case the Court declined to disturb the verdict.

2 Reynell v. Lewis, Wylde v. Hopkins, 15 M. \& W. 517 ; Barker v. Stead, 3 C. B. 946; Norris v. Cottle, 2 H. L. Cas. 647 ; Ex parte Roberts, 
nell v. Lewis, and Wylde v. Hopkins, ${ }^{1}$ which were actions brought by advertising agents and map makers against members of the provisional committee of two railway companies, it appeared in each of the cases that prospectuses and advertisements had been issued by the committee, in which the name of the defendant was set forth as a member of the committee; the plaintiff was employed by the solicitor of the committee; the defendant knew what was being done; but no other facts appeared to show that the defendant had authorized his credit to be pledged. The jury having found for the plaintiff, the Court in each case granted a new trial.

The mere act of executing and filing articles of incorporation by several promoters does not render one responsible for contracts made in the course of the undertaking by the others. Thus in Rutherford v. Hill, articles of incorporation were executed and filed by three persons, one of whom assumed to do business under the proposed corporate name, and contracted debts, before the corporation came into existence. It was held that the others were not liable for such debts. "It is not doubted," said the Court, "that cases might arise, and can readily be imagined, where the incorporators sought to be charged might take such part in conducting the business or hold themselres 2 Mac. \& G. 192 ; Patrick v. Reynolds, 1 C. B. x. s. 727 ; Bailey v. Macaully, 13 Q. B. 815.

In Sproat v. Porter, 9 Mass. 300, decided in 1812, it was held that where persons associate together for the purpose of instituting a banking corporation, and at a meeting of the associates, an agent is employed to attend the legislature for the purpose of procuring a charter, all the associates, including those who did not attend the meeting and did not know of the employment, are jointly liable to the agent for his services. The opinion is very brief, and no authorities are cited. Compare Ward v. Brigham, 127 Mass 25; Dole v. Wooldredge, 135 Mass. 140.

115 M. \& W. 517. 
out to the world as principals in the business, that they would be held liable, but this would grow out of their conduct in carrying on the business, and not out of the mere fact of signing and filing the articles." 1

$\S 236$. Statements in prospectus in which promoter allows his name to be used may impose liability. upon him. - A prospectus or advertisement setting forth the name of the defendant as a member of the committee may, however, contain such announcements as to justify the inference that a general authority has been conferred by the defendant on his co-committee-men, or on others, sufficient to make their acts his acts. Thus, in Collingwood v. Berk$l e y, 2$ a prospectus of a projected company for the conveyance of emigrants to British Columbia contained statements calculated to induce intending emigrants to believe that arrangements had been perfected for the object in view, and inviting them to take tickets for their passage and the public to purchase shares. This prospectus was shown by the secretary to the defendants and they were asked to allow their names to be inserted therein as directors; to which they consented on being qualified, that is, presented each with two hundred paid-up shares, and indemnified. Their names were accordingly inserted, and the prospectus ad-

122 Or. 218; Johnson v. Corsner, 34 Minn. 355; Railroad Gazette v. Wherry, 58 Mo. App. 423. Contra, Wechselberg v. Flour City Nat. Bank, 64 Fed. Rep. 90, Woods, J., dissenting. In this case nothing appeared to show that the party sought to be charged had authorized his credit to be pledged, unless it was the fact that he was one of the incorporators. His co-incorporators began business under the corporate name, before the corporation acquired life, and held him out as an officer. He knew that they were doing business as stated, but did not know that they were holding him out as an officer, and did not participate in the business, nor receive any emolument or profit therefrom. Yet because by slight attention to the matter he might have obtained knowledge of the use of his name, the majority of the Court held that he must be taken to have had that knowledge.

215 C. B. N. s. 145. 
vertised in the Times. Held that from these facts the jury were warranted in inferring that one who contracted with the secretary for a passage, and paid his money upon the faith of the representations contained in the prospectus, did so upon the credit of the defendants, and consequently that he was entitled to sue them for a breach of such contract. The transaction of the prospectus authorized the secretary to hold out that the defendants were really directing him in obtaining fares from emigrants for transport. As against the defendants, the jury was warranted in finding that they did whaterer the Secretary by their authority represented they were doing, within the limit of the operations deseribed in the prospectus, and that therefore, within that limit, they were liable on the contract which the secretary made for them on the credit of their names. It appeared that the secretary had given to the plaintiff a copy of the prospeetus, and the plaintiff stated that he was induced, after reading it, to make the contract in reliance on the credit of the defendants as directors.

$\S 237$. When promoter has acted in undertaking, question for jury whether he has authorized co-promoters to bind him. - If a committee-man not only takes upon himself that character, but also aets in the affairs of the intended company, it is a question for the jury whether or not he has by his acts authorized his fellow members or the solicitor or secretary to pledge his credit for the expenses to be incurred in the formation of the company. For example, if he has attended a meeting of the committee at which it was decided, without dissent on his part, to do all that could be considered necessary to start the company by means of work and materials of a particular description, this is eridence that he sanctioned what it did in the progress of the affair. It tends to show that he knew what the committee was doing, and concurred therein. If the 
authority is found to have been given, it is immaterial that he did not intend to pledge his credit.

$\S 238$. In Riley v. Packington, ${ }^{1}$ - the defendant was associated with one Whitehead and others in the formation of a company. At a meeting of the projectors at which the defendant was chairman, a resolution was passed that the prospectus then read and marked with the defendant's initials be approved and printed for circulation. At a subscquent meeting, of which also the defendant was chairman, a further resolution was passed, " that the prospectus, as altered and marked with the chairman's initials, be approved as the prospectus of the company, and that the same be printed for circulation and advertised at the discretion of Whitehead, as early as possible." Whitehead employed the plaintiffs to print the prospectus, showing them the initial copy and telling them that he was authorized by the defendant to get it printed. The prospectus when printed was delivered at the office of the company, and was adopted and circulated by the defendant. There was an arrangement, not communicated to the plaintiffs, between the defendant and Whitehead, that all expenses of forming the company, down to the allotment of shares, were to be borne by Whitehead. Held that there was evidence from which the jury might infer that Whitehead had authority to pledge the defendant's credit for the printing."

$\S 239$. Promoter's liability on contract made before he became a promoter. - Effect of admission of liability. - Ordinarily, one who becomes a member of the provisional committee

1 L. R. 2 C. P. 536.

2 See also Maddick v. Marshall, 16 C. B. N. s. 387; in error, 17 C. B. N. s. 829 ; Reynell v. Lewis, 15 M. \& W. 517; Norbury's Case, 5 DeG. \& S. 423; Pearson's Case, 3 DeG. M. \& G. 241; Bailey v. Macaully, 13 Q. B. 815 ; Burbridge v. Morris, 3 H. \& C. 664; Roberts Mfg. Co. v. Schlick, 62 Minn. 332; Fredenhall v. Taylor, 26 Wisc. 286. 
is not liable on a contract made by the other members prior thereto, even though the contract is in part executed after he becomes a member. ${ }^{1}$ As the liability of the committeeman arises, not from his filling that character, but from his authorizing, expressly or impliedly, the orders for goods or services, his admission of general liability may be evidence of his having authorized such orders before his name appeared on the committee. The jury are to consider whether the admission was made because the actual liability in law was questionable, and for the purpose of preventing litigation, or whether the admission is referable to a conscientious conviction that his acts have made him personally liable. In the latter case, they may infer his general liability. ${ }^{2}$

$\S 240$. To hold promoter, credit must have been given to him. - If it is found as a fact that a committee-man has authorized his co-committee-men, or others, to hold him out as personally responsible, then the further inquiry is necessary whether or not the credit was given on the faith of his being so personally responsible. He cannot be held if the creditor has looked solely to the deposits on shares, as the fund from which payment is to be made, or solely to the credit of the future company.s

$\$ 241$. Joint liability of promoters. - Effect of release of one. - If promoters are jointly liable on a contract, a release of one releases all. ${ }^{4}$ Thus, in Burgess $\nabla$. Sherman, ${ }^{5}$ the plaintiff assigned his invention, and patent therefor, to

1 Beale ₹. Monk, 10 Q. B. 976.

2 Newton v. Belcher, 12 Q. B. 921 ; Newton v. Liddiard, 12 Q. B. 925; Bailey v. Macaully, 13 Q. B. 815.

${ }^{3}$ Bailey v. Macaully, supra; Thompson v. First Nat. Bank of Toledo, 111 U. S. 529.

4 Newton v. Blunt, 3 C. B. 675 ; Turner v. Davies, 2 Wms. Saund. 148.

5147 Penn. 254. 
five persons, on their agreement to form a corporation to carry the invention into effect, and to pay him a certain sum out of the first sales of its stock. Three of them transferred to a fourth all their interest in the agreement, without the plaintiff's consent, before the corporation was formed. Thereafter powers of attorney to transfer the patent were given to the plaintiff by such transferee, as owner of four-fifths of the patent, and by the remaining party to the agreement as owner of one-fifth, under which the plaintiff transferred the patent to the corporation. Held that having thereby assented to the withdrawal of said three persons from the agreement, he could not recover in an action thereon against any of the parties thereto.

$\S 242$. Right of promoter to indemnity from co-promoters. - If, as matter of fact, a relation of partnership, or agency, exists between promoters, they will, as among themselves, be held in their dealings to the accountability imposed by the rules applicable to partners and agents. ${ }^{1}$ If their conduct or words have been such as to induce third persons, acting reasonably, to believe that they were partners or agents for each other, and to give credit accordingly, on the order of one or more of the members, yet in truth no such relation existed, those upon whom liability has been fixed by the order, but who did not expressly or impliedly authorize it, are entitled to be indemnified by those who have thus put them to loss. ${ }^{2}$

$\S 243$. Right of promoter to contribution from co-promoters. - In case promoters are jointly liable for an indebtedness, and one is obliged to pay the whole debt, he can enforce contribution from his co-promoters. ${ }^{3}$

1 See Chapter VII. as to fiduciary rights and liabilities; Hawk v. Brownell, 120 Ill. 161.

2 Taylor on Corporations, $2 d$ ed., Sect. 80.

8 Boulton v. Peplow, 9 C. B. 483 ; Spottiswoode's Case, 6 DeG. M. \& 
$\S 244$. In Batard v. Hawes, ${ }^{1}$ - it appeared that the plaintiff, the defendant, and several other persons had jointly employed an engineer to make plans and sections and to do engineering work, preparatory to bringing a bill before Parliament for the incorporation of a railway company. The plaintiff was sued by the engineer for the amount of his bill, and was obliged to pay him; and he then brought an action to recover from the defendant his share of contribution. The jury found that there were twelve persons, including the plaintiff and the defendant, who were parties to the original employment of and contract with the engineer, and that two of those per'sons bad died before the plaintiff's payment of the engineer's bill. It having been decided that the plaintiff was entitled to enforce contribution from the defendant, the question arose whether the amount to be contributed by the defendant was to be calculated according to the number of original joint contractors, or according to the number of those who were alive when the payment was made, and against whom the right of the creditor to sue at law had survived. It was held that the plaintiff was entitled to recover from the defendant one-twelfth of the debt, the liability of a co-contractor to one who has paid the entire debt being, at law, to contribute an aliquot part according to the number of persons originally liable, without reference to the number liable at law at the time of payment.

$\S 245$. In absence of agreement, promoter cannot enforce payment for his services from co-promoters. - In the absence of agreement, promoters are not entitled to remuneration G. 345 ; Lefray v. Gore, 1 Jo. \& Lat. 571. But promoters are not, as such, contributories under the English Winding-Up Acts. Bright v. Hutton, 3 H. L. Cas. 341. In 2 Lindley on Partnership (4th ed.), 1375 , the cases directly or indirectly overruled by Bright $\mathbf{v}$. Hutton are enumerated.

12 El. \& B. 287. 
from each other for services in promoting the company. Thus, if one who is the inventor of a scheme procures others to act as a committee, with the intention of forming a company to carry the scheme into effect, and he himself acts as secretary to the committee, he cannot maintain an action against one of the committee for his services, as such secretary, or for his trouble, or for journeys he undertakes in furtherance of the execution of the scheme. ${ }^{1}$

$\S 246$. No contract between promoters to go forward implied from their association together. - The law does not imply, from the mere association together of promoters to organize a corporation, that they have contracted with one another to carry out the enterprise. Accordingly, it has been held that a promoter who is to sell land to a projected corporation cannot hold his co-promoters liable for damages for failure to organize the corporation. ${ }^{2}$ There may, however, be a valid agreement to form a corporation, and, although a Court of Equity will not on well settled principles decree its specific performance, damages may be recovered for loss or injury occasioned by its breach. ${ }^{3}$

$\S 247$. Legality of agreements between promoters as to formation of corporation and its future management and control. - There is no principle of public policy which forbids competent parties from entering into an agreement to form a corporation and providing for its future management and control, if the corporation is created according to statutory requirements, and the objects contemplated are lawful and proper. In King v. Barnes, ${ }^{4}$ the bill of complaint contained in substance the following allegations. The plaintiffs and the defendant $B$. entered into a parol agreement

1 Parkin v. Fry, 2 C. \& P. 311; Wilson v. Curzon, 15 M. \& W. 532; Bailey v. Burgess, 48 N. J. Eq. 411.

2 Crow v. Green, 4 Cent. Rep. (Penn.) 273.

8 Avery v. Ryan, 74 Wisc. 591.

4109 N. Y. 267. 
to the effect that certain real estate should be purchased on joint account, the parties to contribute equally thereto: that a corporation should be organized to take the title, the capital stock to be equally divided between them. B. was made agent of the parties for the purpose of buying the property and organizing the corporation, with authority to select persons temporarily as directors, who were to give place, upon request, to the real parties. The corporation was organized with a capital of $\$ 100,000$ and the defendants P., C., D. and G., together with B., were made directors. All of the capital stock was subscribed for by B., except twenty shares, each of the other directors subscribing for five shares. Real estate was purchased by the associates for $\$ 100,000$ and conveyed to the corporation, in payment for which it issued its entire capital stock. This was delivered to B., with the exception of the twenty shares taken to qualify the directors, but B. refused to transfer to the plaintiffs the shares which they were entitled to under the agreement, contending that the agreement was void by the statute of frauds, as creating an interest in real estate by parol; that it was contrary to public policy and without adequate consideration and was so incomplete and uncertain in its terms that specific performance of its provisions could not be decreed. The court considered these objections to be untenable; and held that the allegations of the complaint presented a case of equitable cognizance, and showed a clear case for an accounting, and trial of all issues incidentally arising upon such accounting.

$\S 248$. Agreement between promoters restricting sale of their stock. - An agreement in writing between the promoters of a corporate enterprise owning ninety-nine onc-hundredths of its capital stock as tenants in common to partition their holdings after first placing in the treasury one-fifth of all the stock, to be sold to provide working capital, and, 
in order to prevent a sacrifice thereof, providing for the deposit of their individual stock certificates with a trust company, each agreeing that he would not withdraw the same for six months except by mutual consent, unless enough treasury stock should be sooner sold to realize a sum named, in which event any one could withdraw his certificates on five days' notice to the others, does not constitute an unlawful suspension of the power of alienation, and is not against public policy, as being in restraint of trade. $^{1}$

1 Williams v. Montgomery, 148 N. Y. 519. 


\section{CHAPTER XII.}

RIGHTS AND LIABILITIES UNDER CONTRACTS MADE BY PROMOTERS CLAIMING TO BE INCORPORATED WHEN THE PROCEEDINGS TAKEN TO INCORPORATE HAVE BEEN DEFECTIVE OR ILLEGAL.

§ 249. Question as to consequences of 1 llegal or defective incorporation by promoters.

250. Theory that corporation cannot come into existence without substantial compliance with enabling statute.

251. Conclusiveness of certificate of incorporation.

252. Nature and attributes of a de facto corporation.

253. Promoters and stockholders of a de facto corporation not liable for its debts.

254. What is necessary to constitute a de facto corporation.

255. A valid enabling statute.

256. Color of apparent organization under statute and user.

257. Effect of apparently real but in fact sham or fraudulent compliance with requirements of statute.

258. Construction of statute by courts of State where enacted followed by courts of otlier States.
$\S 259$. Incorporation for apparently lawful, but in reality unlawful purpose, will not protect promoters.

260. Rule when corporation formed in good faith for lawful purpose.

261. Estoppel to deny corporate existence. Estoppel of the alleged corporation.

262. Estoppel of stockholders and promoters.

263. Estoppel of persons dealing with association as a corporation.

264. Estoppel to deny corporate existence of association in order to hold members individually liable on its contracts.

265. Rights and liabilities under contracts by or with association acting as a corporation, when there is no estoppel and no corporate existence even de facto.

$\S 249$. Question as to consequences of illegal or defective incorporation by promoters. - The subject of rights and liabilities under contracts made by promoters in behalf of a future corporation having been discussed in preceding chapters, a consideration may now be had of the question 
of rights and liabilities under contracts made by promoters claiming to be incorporated and acting professedly as a corporation, but without a de jure organization. Enabling laws under which a corporation may be formed usually provide that, upon compliance with specified requirements, the persons seeking to incorporate shall become a corporation. If such requirements are substantially complied with, a corporation de jure comes into being. The fact of its legal existence cannot be questioned, even by the State, although the State may for lawful cause put an end to that existence by a direct proceeding instituted for the purpose. ${ }^{1}$ Promoters undertaking to bring a corporation into existence for the purpose of doing business under the form of corporate organization may, however, by reason of some illegality, irregularity, defect, or omission in the proceedings taken under the enabling law, fail to form a corporation de jure, and yet in the belief that they have acquired corporate existence, procced to carry on business as a corporation. In such case, it is important to determine what their status and that of those who become members of the supposed corporation is, - whether for any purpose or as to any persons they may be treated as having corporate existence, and if not what are their rights and liabilities.

$\$ 250$. Theory that corporation cannot come into existence without substantial compliance with enabling statute. Probably all courts would agree that there may be a corporation de facto when the only illegality in the steps taken to incorporate is non-compliance or a defective compli-

1 Eakright v. Logansport, \&c. R. R. Co., 13 Ind. 401; Rogers v. Danby Universalist Society, 19 Vt. 187; State v. Central Ohio Mutual Relief Ass'n, 29 Ohio St. 399; Buffalo \& Pittsburgh R. R. Co. v. Hatch, 20 N. Y. 157; Thompson v. People, 23 Wend. 537; People v. Cheeseman, 7 Col. 376 ; Mokelumne Hill Mining Co. v. Woodbury, 14 Cal. 424; People v. Stockton \& Visalia R. R. Co., 45 Cal. 306. 
ance with provisions of the enabling statute which are directory or in the nature of conditions subsequent. But there are cases which maintain the rule that requirements of the enabling statute other than those which are merely directory or plainly made conditions subsequent are to be construed as conditions precedent, which must be met before a corporation can in law or in fact be created, proceedings to incorporate under the statute being void if they do not meet such conditions. ${ }^{1}$ The result of this rulc is that in case of non-compliance with all the conditions precedent of the statute, the corporate existence may be attacked by private individuals. "It is," said the Maryland court, " a question of legal birth. If the corporation had been legally born, its life could only be forfeited and its death declared at the instance of the State; but whether it ever did have life, or in other words, ever was born, scems to us, upon both reason and authority, open to inquiry and contest at the instance of any one suffering from its unauthorized acts." 2

It is plain that the statute should be given such effect only as the Legislature intended. When the statute itself provides that omissions or irregularities in the proceedings shall render the incorporation void, or subject the members

1 Ferris v. Thaw, 72 Mo. 446 ; Abbott v. Omaha Smelting Co., 4 Neb. 416 ; Mokelumne Hill Mining Co. v. Woodbury, 14 Cal. 424; Hurt v. Salisbury, 55 Mo. 311; Boyce v. Trustees of Towsonton Station of M. E. Church, 46 Md. 359 ; Bonaparte v. Baltimore, Hampden, \& Lake Roland R. R. Co., 75 Md. 340; Harris v. McGregor, 29 Cal. 125; Unity Ins. Co. v. Cram, 43 N. H. 636 ; Bigelow v. Gregory, 73 Ill.197; Walton v. Oliver, 49 Kan. 107 ; In re National Debenture \& Assets Co. (1891), 2 Ch. 505; Childs v. Hurd, 32 W. Va. 66 ; Garnett v. Richardson, 35 Ark. 144; Montgomery v. Forbes, 148 Mass. 249; Guckert v. Hacke, 159 Penn. 303.

2 Bonaparte v. Baltimore, Hampden, \& Lake Roland R. R. Co., supra. In Lord v. Essex Building Ass'n, 37 Md. 320, it was held that a second mortgagee might question the corporate existence of the first mortgagee. 
to individual liability, there is no room for question as to the legislative intent. Such is the case in Iowa, where the statute provides that the individual property of the members of a corporation shall be liable for corporate debts in case of failure substantially to comply with the requirements of the statute as to organization and publicity. ${ }^{1}$ But in the absence of an express provision of such nature, should the legislative intent so to provide be inferred? The principle of construction applied by the courts which have adopted the rule in question would seem to be that sometimes employed in the case of a statute which prohibits an act, but imposes no penalty, namely, that the Legislature must have intended to make the prohibited act void, as otherwise the law would be simply " an expression of legislative opinion without means for its enforcement." But the case of the exercise of corporate franchises under an enabling statute without a compliance with all its requirements is to be distinguished from that class of cases in which it is necessary to hold prohibited acts or acts done without a compliance with prescribed conditions void because to hold otherwise would be to render the law nugatory, there being no other way to enforce it. In the case under consideration, this end may be reached by a better and more equitable process. The proper officers of the State may, by quo warranto proceedings, prevent the unlawful exercise of corporate franchises. ${ }^{2}$

It is therefore, in the absence of express provision otherwise, reasonable to infer that this is the sole remedy intended by the Legislature when corporate franchises are

1 Iowa Code, sect. 1618 ; Kaiser v. Lawrence Savings Bank, 56 Iowa, 104 ; Clegg v. Grange Co., 61 Iowa, 121. See also the Louisiana Act, and Field v. Cooks, 16 La. Ann. 153.

2 Elizabethtown Gas Co. v. Green, 46 N. J. Eq. 118; Greene v. People (Ill.), 21 N. E. Rep. 605; People v. Montecito Water Co., 97 Cal. 276;Att'y Gen. v. Hanchett, 42 Mich. 436. 
exercised by virtue of an organization under the statute, but without a full or substantial compliance with all its conditions; it is in the interest of the public so to hold, and the wrong being to the State, and not to private individuals, if redress is to be sought it should be only at the instance of the State. ${ }^{1}$

\section{$\$ 251$. Conclusiveness of certificate of incorporation. -} General laws authorizing the formation of corporations upon performance of stated conditions sometimes contain a provision for the issue of a certificate of incorporation by a public officer designated for the purpose. In such case, notwithstanding non-performance of conditions or fraudulent or evasive compliance therewith, the certificate, if issued, may, eren under the strict theory stated in the preceding section, be conclusive as to the existence of the corporation against all persons but the State. ${ }^{2}$ The conclusiveness of a certificate of incorporation, however, under the theory in question, must depend upon the language of the statute under which it is issued, and it may be conclusive as to some things and not as to others. The English Companies Act, 1862, provides that "any seven or more persons associated for any lawful purpose may, by subscribing their names to a memorandum of association, and otherwise complying with the requirements of this Act in respect of registration, form an incorporated company"; and that "A certificate of the incorporation of any company, given by the registrar, shall be conclusive evidence that all

1 Thus, when a corporation takes a conveyance of land without complying with statutory requirements made conditions precedent to the right so to do, the conveyance is good unless the legislative intent is expressed to make it void for lack of such compliance, and the State alone can take action in the matter. Fritts v. Palmer, 132 U. S. 282; American Morigage Co. of Scotland v. Ternille, $87 \mathrm{Ga} .28$.

2 See Rice v. Nat'l Bank of the Commonwealth, 126 Mass. 300 ; Boston Rubber Shoe Co. v. Boston Rubber Co., 149 Mass. 436. 
requisitions of this Act in respect of registration have been complied with." In In re National Debenture and Assets Corporation, ${ }^{1}$ it was held that a certificate of incorporation under the Act in question was not conclusive that seven persons had signed the memorandum of association, and therefore conclusive of the existence of the corporation. The memorandum in this case purported to bear the subscription of the names of seven persons; it was alleged, however, that in fact it had been signed by six persons only, as one of the signatories had signed twice, once in his own name and once under an assumed name. "The certificate of the registrar," said Bowen, L. J., "cannot cover a fatal blot which is caused by a smaller number of persons purporting to form a corporate body than the Act of Parliament requires. That is clear by the language of sect. 6 and sect. 18 of the Act of 1862 . Sect. 6 provides that seven or more persons may form a company. How ? By subscribing their names to a memorandum of association, and otherwise complying with the requisitions of this Act. It does not say less persons than seven will do. What does it mean by the seven persons complying with the requisitions of the Act? It means that they are to do that which is prescribed by sects. 17 and 18 . Sect. 18 says, ' $\mathrm{A}$ certificate... shall be conclusive evidence that all the requisitions of this Act in respect to registration have been complied with.' Amongst others there is the requisition that seven persons shall subscribe their names. It does not say that less than seven persons can do it." 2

In the United States Banking Act, it is provided that when the Comptroller shall give a banking association a

1 (1891) 2 Ch. 505.

2 See also W. Laxon Co. No. 2 (1892), 3 Ch. 555. Compare Bird's Case, 1 Sim. (s. s.) 47 ; Peel's Case, 2 Ch. 674 ; Oakes v. Turquand, L. R. 2 H. L. 325. 
certificate that the requirements of the Act have been complied with, the association shall have the powers of a bank under the Act, and may begin business as a corporation. It has been held that the Comptroller's certificate is conclusive as against a stockholder in a suit to enforce his liability, and as against a party upon his contract with the bank. ${ }^{1}$

$\$ 252$. Nature and attributes of a de facto corporation. The better view, whether the statute does or does not provide for the issue of a certificate of incorporation, and the one sustained by the weight of modern authority, although some courts of high authority, as we have seen, do not accede to it, is that while a corporation de jure cannot result from anything short of a substantial compliance with all the conditions of the enabling law, a corporation de facto may arise from an incomplete, defective, or irregular compliance with such conditions, whether they are mandatory or directory, conditions precedent or conditions subsequent. A de facto corporation is one which is illegal or illegitimate by reason of some omission, defect, or irregularity in the proceedings taken under the enabling law, but nevertheless has in fact come into being, and accordingly must be treated as existent until its existence is questioned by the State in a direct proceeding brought for that purpose. ${ }^{2}$ So long as the State acquiesces in its existence and exercise of corporate functions, it is under the protection of the same law and governed by the same legal principles as a corpora-

1 Casey v. Galli, 94 U. S. 673.

2 Whitney v. Wyman, 101 U. S. 392 ; Mackall v. Chesapeake Canal Co., 94 U. S. 308 ; Supreme Court of Independent Order of Foresters of Canada v. Supreme Court of United Order of Foresters (Wisc., 1896), $68 \mathrm{~N}$. W. Rep. 1011; McClinch v. Sturgis, 72 Me. 295; Hamilton v. Clarion R. R. Co., 144 Penn. 34; North v. State, 107 Ind. 356 ; Duggan v. Colorado Mortgage and Investment Co., 11 Col. 113; Tarbell $\nabla$. Page, 24 Ill. 46; Lehman v. Warner, 61 Ala. 455; Finch v. Ullman, 105 Mo. 255: Saunders r. Farmer, 62 N. H. 572. See also cases cited infra, note 1 , page 260 . 
tion de jure. " "A corporation de facto," said the California court," "may legally do and perform every act and thing which the same entity could do or perform were it a de jure corporation. As to all the world except the paramount authority under which it acts, and from which it receives its charter, it occupies the same position as though in all respects valid; and even as against the State, except in direct proceedings to arrest its usurpation of power, it is submitted, its acts are to be treated as efficacious."

The assumption and exercise of corporate functions under an imperfect or irregular compliance with the conditions of the statute is a wrong to the State alone, and does not concern individuals as such, unless the Legislature provides otherwise. In the absence of a declaration in the statute itself that a failure to comply with all the conditions specified shall render any attempt to incorporate thereunder absolutely roid, or of some other declaration of similar nature or to the same effect, it is the exclusive prerogative of the State to elect whether to waire or to insist upon the conditions. If a private individual could raise the question, the State's sole prerogative of waiver would be destroyed. Morcover, as the Alabama court has said, "it would produce only disorder and confusion, and embarrass and endanger the rights and interests of all dealing with the association, if the legality of its existence could be drawn in question in every suit to which it was a party, or in which rights were involved springing out of its corporate existence. No judgment could be rendered which could settle the question finally. But when the government intervenes by an appropriate proceeding, the judgment is final and conclusive, putting an end to controversy." 3

I Snider's Sons' Co. v. Troy, 91 Ala. 224.

2 People v. La Rue, 67 Cal. 530.

- Central Agricultural \&. Mechanical Association v. Alabama Gold 
$\S 253$. Promoters and stockholders of a de facto corporation not liable for its debts. - It follows from what has been said as to the nature and attributes of a de facto corporation that promoters and others who are members of such a corporation, or who act and contract in its name and behalf, cannot be held individually liable for the corporate debts, in the absence of an express statutory provision imposing such liability. ${ }^{1}$

$\S 254$. What is necessary to constitute a de facto corporation. - The logic of the theory that the State alone is concerned in a case of an unlawful assumption of corporate functions would seem to lead to the conclusion that persons who in fact act as a corporation must in all cases without exception be treated as a corporation, until the State intervenes. But the courts have not gone so far as this, and there is reason for holding that there should be some limitation. "We must not," as Judge Thompson observes, "get too far away from the primal proposition that the Legislature alone can create a corporation, and that a collection of individuals cannot make themselves a corporation by merely resolving to be such or calling themselves such." 2 Accordingly, in order to create a cor-

Life Ins. Co., 70 Ala. 120. But the rule would not apply against a subscriber for stock in a future corporation. It is an implied condition of such a contract that the corporation shall be created de jure. Rickhoff v. Brown's Sewing Machine Co., 68 Ind. 388 ; Schloss v. Trade Co., 87 Ala. 411; Columbia Electric Co. v. Dixon, 46 Minn. 463.

1 Stout v. Zulick, 48 N. J. L. 600; Cochran v. Arnold, 58 Penn. 399 ; Duggan v. Colorado Investment Co., 11 Col. 113; Vanneman v. Young, 52 N. J. L. 403; Snider's Sons' Co. v. Troy, 91 Ala. 224; Gartside Coal Co. v. Maxwell, 22 Fed. Rep. 197; Whitney v. Wyman, 101 U. S. 392 ; Larned v. Beal, 65 N. H. 184 ; Finnegan v. Knights of Labor Building Ass'n, 52 Minn. 239 ; American Salt Co. v. Heidenheimer, 80 Tex. 344 .

2 Thompson on Corporations, sect. 502. Pettis v. Atkins, $60 \mathrm{Ill}$. 454. "To give to a body of men assuming to act as a corporation 
poration de facto it is held to be necessary that there should be a statute under which the corporation might lawfully be formed, some steps taken to form the corporation under that statute, and user of the corporate franchises assumed. If there is no enabling statute, there cannot be a corporation, for a corporation ean exist only by legislative sanction. If there is no attempt at incorporation under the statute, there can be no valid elaim that a corporation has been formed under it. And if there is not a eorporation in law, there ean be none in fact, unless there is an exercise of corporate functions.

$\S 255$. A valid enabling statute. - There must be a statute under which the eorporation might have been formed. ${ }^{1}$ And the statute must be a valid one. Accordingly, an uneonstitutional statute will not suffice. ${ }^{2}$ But it has been held that an attempted incorporation under a special act which is unconstitutional may give rise to a corporation de facto, if there is a general law under which the corporation might lawfully have been formed. ${ }^{3}$

$\S 256$. Color of apparent organization under statute and user. - There must be color of apparent organization under the statute in order that the eorporation may exist de facto

where there has been no attempt to comply with the provisions of any law authorizing them to become such, the status of a de facto corporation might open the door to frauds upon the public, and it would certainly be impolitic to permit a number of men to have the status of a corporation because there is a law under which they might have become incorporated, and they have agreed among themselves to act, and they have acted, as a corporation." Finnegan v. Knights of Labor Building Ass'n, 52 Minn. 239.

1 Evenson v. Ellingson, 67 Wisc. 634 ; Chicora Co. v. Crews, 6 S. C. 243 ; American Loan \& Trust Co. v. Minnesota \& N.W.R.R. Co., 157 Ill. 641; State v. Critchett, 37 Minn. 13.

2 Eaton v. Walker, 76 Mich. 579 ; Bradenstein v. Hoke, 101 Cal. 131; Re Mendenhall, 9 Nat. Bank Reg. 497 ; Vredenburg v. Behan, 33 La. Ann. 627. Contra, Coxe v. State, 144 N. Y. 396.

${ }^{3}$ MIcTighe v. Macon Construction Co., 94 Ga. 306. 
under that statute. The promoters must take proceedings under the statute to such an extent as unequivocally to indicate that their organization is really intended and attempted to be in pursuance of the statute, by virtue of which alone they can acquire corporate existence. When this appears, although neither full nor substantial compliance with all the conditions of the statute is shown, and although there may liave been a failure as to some substantial requirement, color of apparent organization under the statute is made manifest, and if the statute is valid and authorizes the formation of the corporation, and there is user pursuant to the organization, a corporation de facto is created. ${ }^{1}$

Thus in Duggan v. Colorado Mortgage \& Investment Co., ${ }^{2}$ the promoters took various steps under the statute to organize a corporation, and proceeded to do business as a corporation. But their articles were not acknowledged, as the statute required. And although the articles purported to be signed by three persons, the statute requiring at least three, it was offered to show that one of the signatures was a forgery. It was held that there was a de facto corporation, the court saying: "We are aware of

1 Vanneman v. Young, 52 N. J. L. 403 ; Stout v. Zulick, 48 N. J. L. 601 ; Finnegan $\nabla$. Knights of Labor Building Ass'n, 52 Minn. 239; Duggan v. Colorado Mortgage \& Investment Co., $11 \mathrm{Col}$. 113; McTighe v. Macon Construction Co., 94 Ga. 306 ; Snider's Sons' Co. v. Troy, 91 Ala. 224; Hudson v. Green Hill Seminary, 113 Ill. 618; Bushnell v. Consolidated Ice Machine Co., 133 IIl. 67; Methodist, \&c. Church v. Pickett, 19 N. Y. 482 ; Buffalo \& Allegheny R. R. Co. v. Cary, 26 N. Y. 75 ; People v. Montecito Water Co., 97 Cal. 276 ; Allen v. Long, 80 Tex. 261; Hassleman v. U. S. Mortgage Co., 97 Ind. 368 ; Society of Perun v. Cleveland, 43 Ohio St. 481; Haas v. Bank of Commerce, 41 Neb. 754; Pape v. Capital Bank, 20 Kan. 440 ; Merriman v. Magiveny, 12 Heisk. (Tenn.) 494; Lamning v. Galusha, 81 Hun, 247; Supreme Court of Independent Order of Foresters of Canada v. Supreme Court of United Order of Foresters (Wisc., 1896), 68 N. W. Rep. 1011 ; Clark on Corporations, pp. 90,94 .

211 Col. 113. 
the distinctions between mere omissions or irregularities and what are called ' prerequisities of the statutes.' The distinction may well be taken in a direct proceeding, or other exceptional case where strict proof is required. What is or is not a prerequisite is often a difficult question for a professional man, and much more for a layman, to determine. To cast such a burden upon the public as between the individual members is to lose sight of the reason for, and largely abrogate, the salutary rule respecting de facto corporations." In Society Perun v. Cleveland, 1 the certificate of incorporation filed by the promoters did not state the manner of carrying on the proposed business as required by the statute. In Finnegan v. Knights of Labor Building Association, ${ }^{2}$ the articles filed did not meet the condition of the statute that the place of business should be set forth. But in both cases the court held that there was a corporation de facto. The same conclusion was reached in East Norway Lake Church v. Froislie, ${ }^{3}$ where the certificates of incorporation were not properly executed, acknowledged, or recorded, as prescribed by the statute.

$\S 257$. Effect of apparently real, but in fact sham or fraudulent compliance with requirements of statute. - It is held by some courts to be essential to the existence of a corporation de facto that the attempt to incorporate under the statute shall have been made in good faith, and that when there has been an apparently real, but in fact merely pretentious, sham, or evasive compliance with the requirements of the statute, the lack of good faith or fraud, in the absence of a conclusive certificate of incorporation, vitiates the proceedings, and a corporation de facto is not created. Thus, in Montgomery v. Forbes, ${ }^{4}$ the question of the existence of a corporation under the

143 Ohio St. 481.

252 Minn. 239.
837 Minn. 447.

4148 Mass. 249. 
New Hampshire statute was raised. Under this statute, "any five or more persons of lawful age may, by written articles of agreement, assuciate together for carrying on any lawful business, except banking and the construction and maintenance of a railroad, and when such articles have been executed and recorded in the office of the clerk of the town in which the principal business is to be carried on, and in that of the Secretary of State, they shall be a corporation." "The object for which the corporation is established, the place in which the business is to be carried on, and the amount of the capital stock to be paid in, shall be distinctly set forth in the articles of agreement." It appeared that the defendant, who was a woollen manufacturer in Massachusetts, for the purpose of limiting his personal responsibility and because the laws of New Hampshire were more favorable to corporations than Massachusetts laws, went to Nashua, New Hampshire, to form a eorporation through which to carry on his business. With a local attorney and three other persons secured by the attorney, he executed articles of agreement which were recorded in the office of the clerk of the city of Nashua and in the office of the Secretary of State. These articles recited that the subscribers associated themselves for the purpose of forming a corporation to be called the Forbes Woollen Mills, fixed the amount of the capital stock, and stated that the object of the corporation was to manufacture and sell woollen and other goods, and the places of business were at Nashua, N. H., and East Brookfield, Mass. Meetings of the subscribers were subsequently held, at which the defendant was elected president and treasurer, and such other officers were elected as were necessary under the laws of New Hampshire. All the stock was issued to the defendant, no other person being interested in it. The corporation then began the 
manufacture of woollen goods in East Brookfield, and purchased supplies of the plaintiff, for which the notes of the corporation were given and taken. There was no manufacturing done in Nashua, nor any other business, except the holding of corporate meetings In the trial court the jury found that at the time of the attempted organization the alleged corporation and its members did not intend to carry on its business (other than holding meetings) in whole or in part in Nashua; that there was no attempt in good faith by the defendant to form the corporation; but that the defendant believed that the organization was a valid corporation. The suit was to reeover from the defendant individually the price of the supplies in question, and, on the findings stated, the judge directed a verdict for the plaintiff, which was sustained.

In Jersey City Gas Co. v. Dwight, ${ }^{1}$ the plaintiff corporation sought to be protected against an invasion of its franchise. It had authority under a special charter to lay gas pipes in the streets of Jersey City, and to generate and sell gas for lighting purposes in that city. The defendants claimed the same right, as a corporation formed by them under the name of the Consumers' Gas Company, pursuant to the provisions of a general law. The decision hinged on the question whether the defendants had acquired corporate existence. The law in question provided that a corporation formed under it should exist from the filing of the articles, but that the articles should not be filed until at least one-half of the capital stock had been subseribed, and twenty per cent paid thereon in good faith and in cash, and an affidavit of compliance with such requirement filed. There was an ostensible compliance on the part of the defendants, but in fact a part of the subseription of one-half of the capital stock 
was fictitious, and the required twenty per cent was not paid in in cash, although an affidavit to that effect was filed. The court said: "Any attempt to acquire corporate functions by a pretentious or evasive compliance, no matter what the papers may say, must be denounced as a fraud upon the law. By this law a corporation is made self-creative and a grant of a franchise is made to flow from the act of the grantee; the act is the grant, but to have this effect it must be what the law requires, and not a sham." The defendants, it was accordingly held, had not acquired corporate life and power, and an injunction was issued restraining them from using the public streets of Jersey City for the purpose of laying gas pipes therein. ${ }^{1}$

But the principles on which the rule in relation to a corporation de facto is based apply with peculiar force when private individuals seek to impeach the existence of a corporation on the ground of fraud or lack of good faith in the proceedings taken to secure incorporation. If defects and omissions in the proceedings which are apparent of record and may easily be ascertained, and the effect of which is a question of law, can be taken advantage of only by the State, a fortiori should this be so in a case of alleged fraud or lack of good faith which presents a question of fact in respect to which prospective stockholders or others, howerer honest or diligent, might reach the wrong conclusion and different juries might decide differently. In one case as much as in the other the wrong is to the State, and not to individuals, and it should rest with the State alone to raise the question. ${ }^{2}$

1 To the same effect, see Farnham v. Benedict, 107 N. Y. 159 ; Hill v. Beach, 12 N. J. Eq. 31.

${ }^{2}$ Charles River Bridge Co. v. Warren Bridge, 7 Pick. 314; Duggan v. Colorado Mortgage \& Investment Co., 11 Col. 113 ; Demarest v. Flack, 128 N. Y. 205. 
The difficulties in the way of the contrary doctrine and the confusion which might result from its adoption are set forth in the opinion of the court in Cochran v. Arnold, ${ }^{1}$ as follows: "By one jury a charter may be set aside. By another it may be sustained. One creditor may sue the corporation as such, obtain a judgment, and sell its land, himself becoming the purchaser. Another creditor may sue the corporators, alleging that their charter is null, furnishing no immunity to them. He may obtain a judgment and sell the same land to another purchaser, as the property, not of the corporation, but of the stockholders. In such a case which purchaser would hold the title? Again, new stockholders may come in, totally ignorant of any fraud or mistake in making out the certificate. Are they to be charged individually because there was a secret vice in obtaining corporate being? That would be monstrous. ${ }^{2}$. . . Yet, if a charter can be shown invalid by collateral attack at the suit of a creditor, why are not new stockholders who have come in after the birth of the corporation equally liable as partners, or joint contractors, with all the original stockholders? Can the charter be effective and yet not effective? In Patterson v. Arnold, ${ }^{3}$ it seems to have been thought a charter may be good as to some stockholders and a nullity as to others. What confusion must this produce? Some may be sued as partners, and others through the corporation, and under judgments obtained executions be levied upon the same property. Or all the original stockholders

158 Penn. 399.

2 There are cases which, while recognizing the doctrine that the corporate existence may be impeached by private individuals as against the guilty parties, hold otherwise as to innocent stockholders. American Salt Co. v. Heidenheimer, 80 Tex. 344; Medill v. Collier, 16 Ohio St. 599.

845 Penn. 410. 
may go out and give place to successors. Then that which was incurably vicious, because an usurpation upon the Commonwealth, has become good. It is impossible, however, that a charter can be good as to some stockholders and bad as to others. Every one has an interest in the property of his associates invested in the common stock. Such is his corporate right. If that property can be withdrawn by action against his associates individually, the charter ceases to be to him all that it purports to be. It is said, that those who certify falsely for the purpose of obtaining a charter are guilty of fraud. Doubtless this is so. There is a fraud upon the State. If it be also a fraud upon creditors, the law furnishes a remedy. An action will lie for the fraud. But to deny the corporate existence of a de facto corporation, and to hold as partners those who were guilty of fraud in obtaining the charter, is to confound an action ex contractu with one essentially for a tort."

$\S 258$. Construction of statute by courts of State where enacted followed by courts of other States. - When a court in one State has to determine the interpretation to be placed upon a statute of another State authorizing the formation of corporations, it will inquire whether the courts of the latter State have construed it. If they have passed on the question whether given omissions or defects in the proceedings required for incorporation render an attempted incorporation under the statute void, the courts of the State in which the existence of a corporation alleged to have been formed under the statute in question is denied will, pursuant to the rule of comity, follow the construction adopted by the courts of the State where the statute was enacted. Therefore, when an action was brought in the State of New York against certain stockholders of a company purporting to have been incorporated 
in the State of Iowa, seeking to charge such stockholders with an indebtedness of the company, on the ground that its failure to file its charter in the office of the Secretary of State as required by the Iowa statute had rendered the incorporation void, it appearing that the Supreme Court of Iowa had decided that such filing was not essential to the validity of the incorporation, and that the omission to cause the charter to be so filed would not render the private property of the stockholders liable for the debts of the company, it was held by the New York court that such decision was conclusive as to the construction to be placed on the statute, and that the action was not maintainable. ${ }^{1}$

$\S 259$. Incorporation for apparently lawful, but in reality unlawful purpose, will not protect promoters. - Promoters may bring a corporation into existence for the purpose of doing some unlawful act or carrying on some unlawful business under the form of corporate organization as a shield against personal liability. In such case, they may be held responsible as individuals for their wrong doing, although it is accomplished through the medium of the corporation. The articles of association or charter may indicate that the purpose of the corporation is lawful, but the courts will not, if it is proved that the real intent is to transact an unlawful business, and such business is transacted by the promoters, permit them when sued as individuals to shelter themselves behind the answer of corporate organization. The corporation may have a legal existence, ${ }^{2}$ as a de facto corporation, but of that the wrong doers cannot avail themselves.

1 Jessup v. Carnegie, 80 N. Y. 441.

2 The distinction between calling in question the existence of a corporation and refusing to permit its existence to be availed of in a case of the nature stated must be borne in mind. It is evidently the 
McGrew v. City Produce Exchange ${ }^{1}$ exemplifies the rule. In this case the plaintiff brought suit to recover moneys lost by him on wagers made with the defendants. The defendants were the incorporators of the City Produce Exchange. It appeared that they had combined and confederated together, styling themselves and chartered as the City Produce Exchange for the purpose of buyiug and selling "futures" in cotton and grain, ostensibly, while in reality this was a pretence, the real business intended to be done, and in fact done, being the pretended purchase or sale of such products, for future delivery, under contracts legal and valid in form, but in fact illegal and invalid because of the non-existence of any real intention to buy or sell for such delivery, and so framed and executed as to conceal the real purpose of the parties, which was to gamble on the rise and fall of the products pretended to be bought or sold. It was contended by way of defence to the action that the corporation was alone liable; that, being chartered for a legal purpose, the incorporators could not be held liable for the illegal acts of the managers or officers of the corporation. But the court said: "There is nothing in this defence. The facts justify the finding that the corporation was but a cloak used to cover the illegal acts contemplated in the organization and done as a business; and in such case the form

first case that Mr. Morawetz has in mind when he says : "The mere motive and intention of the parties forming a corporation cannot be inquired into. If the purpose of a corporation, as indicated by its articles of association, is legal, and the incorporation is effected in the manner prescribed by law, the intention of the incorporators is immaterial. Even if the corporation should afterwards, in pursuance of the pre-existing intention of those forming it, depart from its authorized purposes, that would merely be a ground for dissolving it at the suit of the State, as in other cases where a corporation violates the law." Morawetz on Corporations, sect. 758.

185 Tenn. 572. 
of the transaction is disregarded, and the intent and substance ascertained, and liability fixed for the thing done, without respect to the pretence under which it was attempted to be concealed." On the same principle it was held in Smith v. Standard Laundry Machine Co. ${ }^{1}$ that the president of a corporation who owned all the stock was personally liable in damages for the infringement of a patent. "The pretext of doing business in the name of the corporation," the court observed, "is too flimsy to shield him from accounting to the owner of the patent."

$\S 260$. Rule when corporation formed in good faith for lawful purpose. - But a corporation may commit fraudulent or ultra vires acts, and ordinarily the corporators and shareholders are not liable therefor. It may become insolvent, and its creditors cannot in such case, in the absence of statutory liability, look to the corporators or shareholders to make up the deficiency in the corporate assets. $^{2}$ The rule stated in the preceding section is not applicable when the corporation is really formed to do that which as a corporation it lawfully may do, and is not employed as a mere cloak to cover designed fraud. ${ }^{3}$

$\S 261$. Estoppel to deny corporate existence. - Estoppel of the alleged corporation. - Promoters who have failed to form a corporation either in law or in fact may yet, in the belief or without the belief that they have formed a valid corporation, claim to have corporate existence, and contract and carry on business professedly as an existing corporation. It is well settled in this case that, if the

119 Fed. Rep. 826.

2 Cook's Stock and Stockholders, and Corporation Loan, sect. $663 \mathrm{~b}$.

${ }^{8}$ Atchison, Topeka, \& Santa Fe Ry. Co. v. Davis, 34 Kan. 209. See Kankakee \& Seneca R. R. Co. v. Horan, 131 Ill. 288, the decision in which ignores the doctrine stated in the text. See also article "Liability of an Organizer of a Corporation," 27 American Law Review, 361. 
association gotten up by them holds itself out as a corporation in business transactions with other persons, it will be estopped against such persons as to such transactious to deny that it is a corporation for the purpose of defeating their rights. ${ }^{1}$

§ 262. Estoppel of stockholders and promoters. - The estoppel extends to the members or stockholders of the association, as against persons with whom the association has dealt as a corporation. Thus, when an organization assumes to act as a corporation, and issues and puts in circulation bonds secured by a mortgage, stockholders in the organization, as such, cannot defeat the bonds and mortgage by alleging that the organization was not duly incorporated. ${ }^{2}$ And stockholders in a professed corporation when called upon, as such, to respond to a liability, are not permitted to deny the existence or the legal validity of the corporation. ${ }^{3}$ Promoters are likewise estopped to question the existence of the corporation when suit is brought against them in its behalf to enforce rights growing out of their acts as promoters. For example, if they have improperly obtained secret profits at the expense of the corporation they are estopped in a suit brought by it to recover such profits to deny the legality of the organization. ${ }^{4}$

1 Callender v. Plainsville \& Hudson R. R. Co., 11 Ohio St. 516; Stewart Paper Mfg. Co. v. Rau, 92 Ga. 511; Ten Eyck v. Pontiac, Oxford, \& Port A ustin R. R. Co., 74 Mich. 226; Dooley v. Cheshire Glass Co., 15 Gray, 494. Contra, Boyce v. Trustees of Towsonton Station of M.E. Church, $46 \mathrm{Md}$. 359. If the defendant has contracted as an association or organization under the name by which it is sued, it is immaterial, so far as the plaintiff's right of recovery is concerned, whether it is a corporation de jure, a corporation de facto, or a mere voluntary association. Perine v. Grand Lodge, 48 Minn. 82.

2 Phinizy v. Augusta \& K. R. Co., 62 Fed. Rep. 678. See also Beal v. Bass, 86 Me. 325.

${ }^{8}$ Casey v. Galli, 94 U. S. 673.

4 Pittsburg Mining Co. v. Spooner, 74 Wisc. 307. 
$\S 263$. Estoppel of persons dealing with association as a corporation. - Persons who contract with an association as a corporation are estopped when it secks to enforce the contract to deny that it is a corporation. "Parties must take the consequences of the position they assume. They are estopped to deny the reality of the state of things which they have made appear to exist, and upon which others have been led to rely. Sound ethics require that the apparent, in its effects and consequences, should be as if it were real, and the law properly so regards it." 1 Thus the execution of a note to the payee as a corporation will estop the maker to deny that the payee is a corporation, in a suit brought upon the note. ${ }^{2}$ And so one who makes a conveyance to persons assuming to be a corporation, and describes them in the deed as a corporation, will be debarred thereby from disputing their corporate existence, for the purpose of defeating the deed. ${ }^{3} \mathrm{~A}$ person who has recognized, dealt with, and become a stockholder in a de facto corporation, is estopped in an action on his subscription to assert that it never was legally organized. ${ }^{4}$ But a subscriber for stock in a future corporation, as distinguished from one held out to be in existence, is not from that fact alone estopped, in a suit brought to enforce the contract of subscription, to set up as a defence that the corporation has not come into being.

1 Swayne, J., in Casey v. Galli, 94 U. S. 673; Close v. Glenwood Cemetery, 107 U. S. 467 ; Commercial Bank of Keokuk v. Pfeiffer, 108 N. Y. 242; Ragan ₹. McElroy, 98 Mo. 349 ; Searcy v. Yarnell, 47 Ark. 269 ; Stofflett $\nabla$. Strome, 101 Mich. 197; Wingett v. Quincy Building Association, 128 Ill. 67; Bank of Shasta v. Boyd, 99 Cal. 604 ; Butchers \&. Drovers' Bank v. McDonald, 130 Mass. 264; Spahr v. Farmers' Bank, 94 Penn. 429; Tuckaseegee Mining Co. v. Goodhue, 118 N. C. 981.

2 Brickley v. Edwards, 131 Ind. 3.

8 Whitney v. Robinson, 53 Wisc. 309.

4 Hause v. Hannenheimer (Minn., 1896), 69 N. W. Rep. 810. 
Such a contract does not recognize the corporate existence, and it is an implied condition that the corporation shall be created de jure. ${ }^{1}$

\section{$\S 264$. Estoppel to deny corporate existence of associa-} tion in order to hold members individually liable on its contracts. - It follows from the rule stated in the preceding section that persons who contract with an association as a corporation are estopped, at least in those jurisdictions where the rule of estoppel is not limited to de facto corporations, from setting up that the association is not a corporation for the purpose of holding the members individually liable on the contract. ${ }^{2}$ To support the estoppel

1 Rickhoff $\nabla$. Brown's Sewing Machine Co., 68 Ind. 388; Columbia Electric Co. v. Dixon, 46 Minn. 463; Schloss v. Trade Co., 87 Ala. 411. There are direct decisions to the effect that the rule of estoppel stated in the text is applicable only when the association contracted with as a corporation is at least a de facto corporation. Jones $\mathbf{v}$. Aspen Harlware Co., 21 Col. 263; Bradenstein v. Hoke, 101 Cal. 131 ; Empire Mills v. Alston Grocery Co. (Tex. App.), 15 S. W. Rep. 505; Snyder v. Studebaker, 19 Ind. 462 ; and there are dicta and apparent holdings to the same effect in quite a number of cases. But ordinarily there would seem to be no sound reason for such a distinction. For a discussion of the question, see Clark on Corporations, p. 105 et seq., where the cases are collected. Perhaps the rule should not be applied in the case of a subscription for stock in what is held out and supposed to be an existing corporation, but in reality is not even a corporation de facto. If it is applied, the subscriber may be compelled to take what he has not bargained for - shares in a mere voluntary association, and this would seem to be unjust, except in those cases where he is estopped by reason of bis participating in the organization or business of the association as a promoter or stockholder.

2 Snider's Sons' Co. v. Troy, 91 Ala. 224 ; Stout v. Zulick, 48 N. J. L. 599; Planters \& Miners' Bank v. Padgett, 69 Ga. 159; Merchants \&. Manufacturers' Bank v. Stone, 38 Mich. 779; Johnston ن. Gumbel (Miss., 1896), 19 So. Rep. 100 ; Nebraska Nat. Bank of York v. Ferguson (Neb., 1896), 68 N. W. Rep. 370. The cases on the individual liability of members of a pretended corporation fall into several classes : -

(1) Those which, without taking into account the doctrine of es- 
in such case, however, it must appear that in the making of the contract the corporate existence has been recognized, and that the contract was made with the association as a corporate body. One who contracts with an association, in ignorance of its claim to be a corporation, is not estopped to contend that the members are individually liable to him. The mere fact that the contract is in the name of a company, and is signed by officers of the company as such, does not create a presumption that the company is a corporation; it is equally consistent with the theory that the company is a voluntary association, or a partnership, or composed of a single individual. Unincorporated associations, partnerships, and individuals as frequently use company names, perhaps, as do corporations, and often adopt the forms and methods of business corporations, conducting their business by a president or treasurer. ${ }^{1}$

$\S 265$. Rights and liabilities under contracts by or with association acting as a corporation, when there is no estoppel and no corporate existence even de facto. - Under these conditions the rights of the association will be protected

toppel, hold the members exempt on the ground that the association is a de facto corporation; e. g. American Salt Co. v. Heidenheimer, 80 Tex. 344.

(2) Those which hold, apart from any question of estoppel, that the association is not a partnership; e. g. Fay v. Noble, 7 Cush. 188.

(3) Those which expressly hold that, the association not being even a de facto corporation, the rule of estoppel does not apply. Empire Mills v. Alston Grocery Co. (Tex. App.), 15 S. W. Rep. 505. The remaining cases are perhaps inferentially within this class. See, for example, Montgomery v. Forbes, 148 Mass. 249.

1 Duke v. Taylor, 37 Fla. 64; Guckert v. Haeke, 159 Penn. 303 ; New York Nat. Exchange Bank v. Crowell (Penn., 1896), 35 At. Rep. 613 ; Clark v. Jones, 87 Ala. 474; Eaton v. Walker, 76 Mich. 579; Hungerford Nat. Bank v. Van Nostrand, 106 Mass. 559 ; Clark on Corporations, p. 102. 
by the courts. Thus, in Insurance Company v. Harbor Protection Co., ${ }^{1}$ certain corporations had attempted without right to form a corporation under the general laws, and the supposed new corporation had acquired property. It was held that this property belonged to the holders of certificates of stock, and that the court would order it sold and the proceeds divided among them. As to the liability of the members, the rule is maintained in quite a number of jurisdictions that the association is a partnership, the members being liable to creditors accordingly, although they have not agreed to become partners or held themselves out as a partnership. ${ }^{2}$ But it seems clear that, in the absence of such an agreement or holding out, this rule cannot be justified by any principle of the law of partnership. ${ }^{3}$ In some of the cases in which it has been announced and applied, it has apparently been made to rest on the ground of public policy. In other words, it has been established by judicial legislation. ${ }^{4}$ In other cases it appears to have resulted from the theory that every association or organization must be either a partnership or a corporation; but this is not true; a voluntary association may or not be a partuership, and its members may or may not be liable as partners to creditors. This must depend upon what they have agreed, or held themselves out to be.

137 La. Ann. 233.

2 Bigelow v. Gregory, 73 Ill. 197; Loverin v. McLaughlin, $161 \mathrm{Ill.}$ 417, 435; Abbott v. Omaha Smelting Co., 4 Neb.416; Guckert v. Hacke, 159 Penn. 303 ; New York Nat. Exchange Bank v. Crowell (Penn., 1896), 35 At. Rep. 613 ; Garnett v. Richardson, 35 Ark. 144; Ferris v. Thaw, 72 Mo. 446; Coleman v. Coleman, 78 Ind. 344; Empire Mills v. Alston Grocery Co. (Tex. App.), 15 S. W. Rep. 505; Smith v. Warden, 86 Mo. 382 ; Dake v. Taylor, 37 Fla. 64; Eaton v. Walker, 76 Mich. 579 ; Shields v. Clifton Land \& Improvement Co., 94 Tenn. 123.

3 Bates's Law of Partnership, sect. 4.

4 But in Iowa the statute expressly imposes the liability. Clegg $\nabla$. Hamilton \& Wright Grange Co., 61 Ia. 121. 
Moreover the rule is unjust to innocent stockholders, and tends to produce great inconveniences and hordships, imposing, as it does, on purchasers of stock in the market the burden of causing an investigation to be made to determine whether or not the corporation has been legally formed. Ordinarily this is not practicable.

If the members of a supposed or alleged corporation have not agreed to form a partnership or held themselves out as partners, and the statute does not in terms impose upon them partnership liability, the true view is that their liability is to be tested by the principles of the law of agency. ${ }^{1}$ When the members of an association sought to be charged on a contract made with it as a corporation supposed the association to be a corporation, and did not enter into the contract personally, and there is no statutory liability, no valid reason exists why they should be individually held on the contract, unless the officers or managers who made it were their agents with authority to make it in their behalf. And there is no justification for inferring such agency and authority from the mere fact of their membership. That fact does not tend to show an agency for them as individuals. On the contrary, it establishes only an attempted agency for the supposed corporation. And so far as a holding out of an agency in such case goes, it is not a holding out of an agency for the members individually, but of an agency for a corporation. The result, it is true, is that the officers or managers making the contract have no principal behind them, the corporation being non-existent; but this is

1 Fay v. Noble, 7 Cush. 188 ; Stafford National Bank v. Palmer, 47 Conn. 443; First National Bank v. Almy, 117 Mass. 476; Ward v. Brigham, 127 Mass. 24; Seacord v. Pendleton, 55 Hun, 579; Humphreys v. Mooney, 5 Col. 282; Medill v. Collier, 16 Ohio St. 599 ; Blanchard v. Kaull, 44 Cal. 440. 
not anomalous. Not infrequently a contract fails because one of the parties in whose behalf it purports to have been made, and whom it was intended to charge, turns out to be non-cxistent, or because such party did not authorize the contract to be made for him. The remedy here is plain, those who actually made the contract as that of an existing corporation being liable in damages to the other party to the contract, if they have misled him to his injury by their action. ${ }^{1}$

The agency of promoters, officers, or managers of an alleged corporation for the members thereof, as individuals, may, however, be expressly created by or implied from the acts of such members. For reasons already stated, the inference is not to be drawn from the mere fact that the members chose or appointed the officers or managers who made the contract, and authorized them to act for the supposed corporation, nor from the mere fact that the members have received dividends as stockholders. But if they knew at the outset or subsequently became aware that the association was not a corporation, and then, by continuing as members or otherwise, acquiesced in the carrying on of the business by the officers or managers, they may be held as principals. ${ }^{2}$

1 See sect. 230.

2 Seacord v. Pendleton, 55 Hun, 579; Fuller v. Rowe, 57 N. Y. 23 ; Central City Savings Bank v. Walker, 66 N. Y. 583; Medill v. Collier, 16 Ohio St. 599 ; Johnson v. Corsner, 34 Minn. 355. 
I N D E X. 



\section{N D EX.}

References are to Sections.

\section{ABORTIVE CORPORATION,}

promoter's liability to subscribers for shares for money advanced, 162.

expenses not to be deducted unless authorized, 163 .

payment to promoter or his agent must be shown, 164-166.

lien, none in favor of subscriber for shares as against creditors, 167.

remedy at law unless fraud or necessity for accounting shown, 168 . bill for an accounting, 169 .

ACCEPTANCE,

by corporation of promoter's contracts. (See Contracts of

Promoters.)

ACCOUNTABILITY,

of promoters generally, 23.

of promoters to corporation,

for benefit of purchase, 42-57.

none from mere fact that purchase made by promoter while such, 44 .

none when made before promoter became such, 46-48.

unless certain declarations are made, 51-53.

for benefit of option, 54-56.

for benefit of option held by one confederating with promoter, 58,59 .

effect of certain declarations, 55-57.

for benefit when corporation makes payment in its stock, 83 . remedy 1 , by recovery of stock and dividends paid thereon, 83.

remedy 2 , by recovery of highest intermediate value of stock, 83.

remedy 3 , by recovery of amount received by promoter for stock, if sold, with dividends, 83 .

distinction between benefit and profit, 60 .

for profit on sale to corporation of property bought by promoter before he became such, 60-62.

when property has a market price, 61 .

none when purchase by corporation has been properly approved, 61.

where property has no market price, 62 .

net profit only to be accounted for, 79 . 
ACCOUNTABIIITY - continued.

for promotion inoney, 64-74.

net proceeds only to be accounted for, 79 .

but no allowance for expenses ultra vires the corporation, 80 . for commissions received from vendor to corporation, 64-75,

$77,78,83$.

for interest, 82 .

action survives against promoter's administrator or executor, 89.

burden of proof, 104.

statute of limitations, 84-87.

estoppel of corporation, 88 .

of promoter to shareholders and subscribers for shares, 123-125.

joinder of plaintiff, 126 .

for misrepresentations. (See Subscribers for Shares.)

for money advanced, when project fails. (See ABortive

Corporation.)

of persons confederating with promoters, 76 .

for benefit of option, 58,59 .

of vendor to corporation having secret agreement with promoter, 75 . distinguished from liability for damages, 46.

\section{ACTION,}

by corporation against promoter,

for an accounting, may be barred by statute of limitations, 84-87.

may be divested, how, 88 .

for damages, will not ordinarily lie for misfeasance, 90 .

will lie for fraud, 76, 90, 92 .

for injurious violation of duty to corporation, 91 .

if misfeasance causes pecuniary loss, 91, 92.

form of action, deceit, 92 .

when for accounting, survives against executor or adminis-

trator of promoter, 89 .

for rescission. (See REscrssion.)

suit by minority shareholders. (See Shareholders' Bill.)

by subscriber for shares against promoter,

for damages for concealment or misrepresentation or for accounting, when fiduciary relation exists, 123-129.

for damages for concealment or misrepresentation, when fiduciary relation does not exist. (See Subscribers for Shares.)

by subscriber for shares against corporation,

ordinarily none for frauds of promoter before organization, 171.

action of deceit, 170-172.

effect of insolvency of corporation upon, 172.

action for money had and received, 174.

rescission of contract of subscription. (See Rescissior.) 
ADMISSION,

by promoter of liability on contract made by him before he became such, effect of, 239.

\section{ADOP'TION,}

by corporation of promoter's contracts. (See Contracts of Promoters.)

\section{AGENT,}

not necessarily a promoter, $2-4$.

may be promoter although compensation does not come from corporation, 5 .

of vendor to corporation, when liable as promoter, 4 .

of stranger becomes a promoter, when, 5,6 .

promoters not prima facie each other's agents, 233.

AGREEMENT TO PROMOTE,

does not alone make one a promoter, 16.

AGREEMENTS,

of promoters must be disclosed in prospectus, in England, 154.

different rule in United States, 153.

(See also Contracts.)

ASSOCIATION ACTING AS A CORPORATION, BUT NOT

SUCH EVEN DE FACTO, estoppel to deny legal incorporation, 261-264.

members held as partners in some jurisdictions; rule criticised, 265.

question of agency, one member for another, question of fact, 265 . ordinarily no agency for members individually, 265.

may be imposed upon members by statute, 265 .

agency may arise from knowledge by members of illegality of incorporation, 265.

\section{BENEFIT, (See Accountability.)}

of option held by promoter, when corporation may have, $54,56,57$. corporation may have, if promoter offers corporation advantage of option, 55 .

of option held by third person confederating with promoter, when corporation may have, 58,59 .

of secret promotion money, corporation entitled to, 64-74.

of purchase made by promoter acting as such; corporation's right to claim, 42,43 .

no right from mere fact that purchase made by promoter while such, 44 .

no right in corporation to benefit of purchase or option in case of certain disclosures by promoter, 42 .

of purchase made by promoter before he became such, corporation may not have, $46-48$.

unless promoter has made certain declarations, 51-53. 


\section{BURDEN OF PROOF,}

in actions to rescind, 104, 190.

to recover secret profits, 104.

upon corporation to show waiver or laches, when, 190.

\section{CAVEAT EMPTOR,}

applicable in dealings between promoter and subscriber for shares, 130, n. 1, 182.

not applicable to dealings between promoter and corporation, 98 .

\section{CERTIFICATE OF INCORPORATION,} how far conclusive, 251.

COLORABLE TRANSFER OF PROPERTY TO PROMOTER, court will go behind in determining measure of accountability, 49,50 .

\section{COMMENDATORY EXPRESSIONS,}

by promoters to subscribers for shares privileged, not actionable, 133.

\section{COMMISSIONS,}

when secretly paid promoter by vendor to corporation, to be accounted for, 4, 63-74.

when secretly secured by promoter, not at expense of corporation, to be accounted for, 77,78 .

analogy of trustee, 78.

accountability of persons confederating with promoters, 76 .

rule as to recovery when commission in form of shares of corporar tion's stock, 83 .

interest, 82.

statute of limitations, $84-87$.

estoppel of corporation, 88 .

\section{COMPANIES ACTS,}

English decisions in some cases based upon, 80.

corporation allowed to pay promoter reasonable expenses, 81 .

requirements of, as to disclosure of promoter's contracts in prospectus, 154.

CONCEAlment, (See Non-Disclosure by Promoters.)

of material facts iniplies fraudulent misrepresentation, 147.

when fiduciary relation exists, ground for damages in suit by shareholders against promoters, 127-129.

\section{CONFEDERATES OF PROMOTERS,}

liable to account or in damages to corporation, $58,59,76$.

CONSPIRACY,

what misrepresentations of promoters will support indictment for, 156. 


\section{CONTRACTS.}

between promoters,

none implied for payment by co-promoters for services, 245. none implied as to going forward with undertaking, 246. as to formation and management of corporation, 247.

restricting sale of their stock, legal and not against public policy, 248.

between promoter and corporation,

in making corporation must ordinarily act through disinterested board of directors, 26.

promoter's duty to see that corpolation does so act, 24 .

rule otherwise when full disclosure made and shareholders consent, 27.

when promoter has received secret benefits, corporation may have accounting, 94 .

under some circumstances corporation may ratify contract, 100.

under some circumstances corporation may rescind contract, 94-96, 100.

caveat emptor not applicable to dealings by promoters with corporation, 98 .

corporation may not rescind when promoter has disclosed his position and interest, 94-96.

in case of rescission, consideration to be returned, 102.

except in cases, its equivalent, 102.

when worthless, need not be returned, 102 .

laches, effect of, on right to rescind, 101.

by promoters in behalf of projected corporation,

corporation not ordinarily bound by, 194-198.

corporation cannot ordinarily enforce, 194-197.

liability of corporation in equity where promoters are the only sliareholders, $194 \mathrm{n}$.

corporation not liable where it has not availed itself of contract, 198.

contract cannot be ratified by corporation, 199 .

equitable doctrine of Lord Cottenham, 200.

Lord Cottenham's doctrine not universally accepted, 201. contract may be accepted or adopted by corporation, 202. effect of such adoption or acceptance, 203.

distinguished from ratification, 203, 214.

acceptance or adoption may be express or implied, 204, 205. acceptance or adoption may be inference of fact, 206-210.

inference may be from taking of benefit of contract, 207210.

taking of benefit of contract only evidence of acceptance, 207. ordinarily proof when contract is in name of corporation, 208.

or in its behalf, 209 . 


\section{CONTRACTS - continued.}

rule of acceptance or adoption applicable to subscription for shares, 211.

modification in some jurisdictions, $211, \mathrm{n} .1$.

"ratification" distinguished from " acceptance" and "adoption," 214.

"ratification" used meaning acceptance or adoption, 212, 213. distinction sometimes of vital importance, 214.

English doctrine, new contract with new consideration, 215, 216.

new contract may be inferred from facts, 215, 216.

but not from mere taking benefits of prior contract, 215 . followed apparently in Massachusetts, 215, n. 1. ultra vires contracts cannot be accepted or adopted, 217 . test to determine what contract can be accepted or adopted, 217.

promoter's liability on, when made in name or on behalf of projected corporation, ordinarily none, $225,230$.

unless credit given on promoter's responsibility, 240 . question of intention, $225-227$.

presumption when corporation does not exist, 226.

presumption may be overcome, 226 .

if contract oral, jury to interpret, $226,227$.

if contract written, court to interpret, 228, 229.

construing document " ut magis valeat quam pereat," 228, 229.

construction of words " on behalf of " corporation, 228 .

when credit given to corporation, promoter not liable on contract, 230 .

but may be liable for misrepresentation as to existence of corporation, 230 .

remedy when misrepresentations are innocent, 230 .

when misrepresentations are fraudulent, 230 .

when credit given promoter, effect of adoption by corporation, 231.

promoter still liable, 231.

creditor to elect between promoter and corporation, 231 . corporation to indemnify promoter if promoter held liable, 231.

when made by co-promoters. (See Liability of Promoters for Acts of Co-promoters.)

right of promoter to enforce, when made in name or on behalf of projected corporation, 231, 232.

rights and liabilities under, when incorporation defective, 249-265.

(See also Association and De Facto Corporation.)

right of corporation to rescind contracts for fraud or breach of duty of promoters. (See Rescission by Corporation.) 


\section{CO-PROMOTERS,}

right to contribution when held liable, 242-244.

right to payment for services, none unless agreed, 245.

misrepresentations by promoter, liable for, when, 157.

not presumptively partners; anthority must be shown, 233.

liability of promoter for acts of. (See LiABILITy of Promoters.)

\section{CORPORATION,}

when contracting with promoter, must act through disinterested board of directors, 26 .

exceptions to rule, 27.

interest of, duty of promoter to protect, 21.

burden upon, to show laches or waiver in suits on subscription for shares, 190.

burden of proof in suits for rescission or to recover secret profits, 104.

liability of, for expenses incident to formation. (See LIABILITY of Corporation.)

for misrepresentations of promoters. (See Subscribers FOR SHAREs.)

usually none for misrepresentations or non-disclosures of promoters before formation, 173.

rescission of subscription for shares, when, 173.

statements in prospectus not severable from application for shares, 173.

none for frauds of promoters before organization, 171.

action of deceit lies, when, 170.

insolvency of corporation, effect of on its liability, 172.

on right of subscriber for shares to rescind subscription, $191,192$.

right to an accounting for benefit of purchase by promoter upon sale by him to corporation, 42,43 .

none from mere fact that purchase made by promoter while such, 44.

none if purchase made before promoter became such, $46-48$. unless promoter is bound by certain declarations, 51-53. benefit of promoter from option, when to be accounted for, 54-57.

benefit of option held by third person confederating with promoter, 58,59 .

for secret profit of promoter on sale of property having a market value, 61 .

when property has not market value, 62 .

for promotion money in hands of vendor, 75 .

for net profit of promoter only, 79.

but promoter not allowed for expenses ultra vires of corporation, 80 .

for promotion money in hands of promoter, 64-74. 


\section{CORPORATION - continued.}

References are to Sections.

may have interest on money recovered from promoter, 82.

may rescind certain contracts for breach of duty or fraud by pro

moters. (See Rescissiox.)

right of rescission may be barred by laches, 101 .

may ratify certain acts, expressly or impliedly, 100 .

ratification irrevocable if intelligently made, 100. (See also

Contracts of Promoters.)

actions by, against promoters,

for an accounting, may be barred by statute of limitations, 84,85 .

for an accounting, may be divested, how, 88 .

for an accounting, survives against promoter's executor or administrator, 89.

will lie for fraud, $76,90,92$.

none ordinarily for damages for misfeasance, $90,92$.

will lie for misfeasance, occasioning pecuniary loss to corporation, $91,92$.

will lie for injurious violation of duty to corporation, 91 .

form of action, deceit, 92 .

right of shareholders to sue to enforce corporate rights or redress

corporate wrongs. (See Shareholders' BiLl.)

de facto corporation, nature and attributes of, 252.

what necessary to constitute, 254-256.

estoppel of corporation to deny its legal organization, 261. right and liabilities generally. (See Accountability, Action, Contracts, Subscribers for Shares.)

Dallages, (See Action, Liability, Misfeasance, Misreppesentation, Subscribers for Shares.)

measure of, various rules, 158.

Massachusetts rule, 159.

New Jersey rule, 160.

English rule, also in United States Supreme Court, 161.

DE FACTO CORPORATION,

rights and liabilities under contracts of, generally, 249 .

nature and attributes, 252.

distinguished from corporation de jure, 252.

to be treated as corporation except by State, 252.

subscribers for shares before incorporation may question legal existence of, 252, n. 3 .

promoters and shareholders not liable for its debts, 253.

what constitutes, 254 .

a. valid enabling statute under which incorporation possible, 255.

b. attempt to incorporate, and imperfect compliance with law, 256.

attempt must be bona fide to avoid personal liability, 257. 


\section{DE FACTO CORPORATION - continued.}

c. user of corporate privileges, 254.

results from allowing individuals to impeach legality of, 257.

construction of incorporation statute by domestic court followed

DECEIT,

in foreign jurisdictions, 258.

action of, lies against corporation, 170.

(See Action, Corporation, Subscribers for Shares.)

DECLARATIONS OF PROMOTERS,

of mere fact of interest, to shareholders, sufficient, 35 .

of mere fact of interest, to directors, insufficient, 33, 34 .

as to property purchased before becoming promoter, what make

him accountable, 51-53.

as to property sold corporation on which promoter had option, what make hin accountable, 55-57.

DEFECTIVE INCORPORATION, (See INCoRPoration.)

results of, upon contracts of promoters, 249

DIRECTOR,

promise to become, may make one a promoter, 13 .

promising to qualify and qualifying of directors may make one a promoter, 14.

what disclosure by promoter to directors sufficient, 33,34 .

DISABILITY OF CORPORATION, ground for shareholders' bill, 106, 107.

DISCLOSURE,

duty of promoters to make, to corporation when selling property to it, 26.

Lord Cairns' rule as to, 26.

rule when promoters are the sole shareholders, 27.

must be of nature and amount of interest, 28 .

of price paid by promoters not necessary, when, 29 .

of fact of interest alone, to directors, ordinarily insufficient, 33, 34. of fact of interest alone, to body of shareholders, sufficient, 35 .

to whom disclosure must be made and by whom acted upon, 38 .

to all the shareholders, and assent by them, effect of, 39 .

when binding on future shareholders, 39 .

when stock not all issued, 40 .

when transaction is ultra vires, 41 .

necessary in spite of certain provisions in articles of association, 36,37 .

of agreements of promoters must be in prospectus in England, 154 . otherwise in United States, 153.

want of, as ground for action for damages by subscribers for shares against promoters, 127-129, 148-152.

whether legal or moral duty of promoters to disclose material

facts to subscribers for shares, 178-183.

want of. (See also Non-Disclosure.) 
DUTIES OF PROMOTERS,

generally, 16.

similar to those of trustee or agent, 21,42 .

to make reasonable use of their powers, 21.

to exercise good faith in dealings with or for corporation, 23.

to provide competent and disinterested board of directors, 24, 27 .

to see that directors act impartially, 25, 27.

not to receive commissions or gifts from vendors to corporation, 63,64 .

to make certain disclosures, 26 .

to disclose their interest in transactions with corporation, 28, 36 .

as vendors to corporation, when necessary to disclose price paid by them, 28-30.

mere declaration of interest, without stating nature and amount, not enough when made to directors only, 33, 34 .

but such declaration sufficient if made to the shareholders, 35 .

to disclose material facts to subscribers for shares, whether legal or moral duty, 178-183.

remedy for breach of duty. (See Accountability, Acrion, Corporation, Misfeasance, Subscribers for Shares.)

\section{ESTOPPEL,}

of association and promoters to deny legal incorporation, 261, 262. of persons dealing with association as corporation to deny its corporate existence in suits by it, 263.

when subscriber for shares not estopped to deny existence of corporation, 263.

of persons dealing with association as corporation to allege want of corporate existence to hold members individually, 264.

recognition of corporate existence necessary to support estoppel, 264.

EVIDENCE OF PROMOTERSHIP, generally, 1-18.

EXPENSES OF INCORPORATION, liability of corporation to pay. (See LIABILITY of Corporation.)

FIDUCIARY RELATIONSHIP, between promoter and corporation, 21, 22 . consequences of such relationship, 23.

between promoter and subscriber for shares, 123-126, 127-130.

FORMATION OF CORPORATION. (See DE Facto Corporation, Duties of Pronoters, Liability.)

FRAUD, (See Liability.)

by promoters ground for action for damages by corporation, 90, 92 . for rescission of contracts, 97 .

when prior to organization, not ground for action against corporation, 171. 
References are to Sections.

FRAUD - continued.

as a defence in action by corporation against subscriber for shares, 174.

as ground for action of shareholders against promoters. (Sce Subscribers for Shares.)

by majority shareholders, ground for shareholders' bill by minority shareholders, 108-112, 116, 118.

Gift. (See Commission, Profit.)

GOOD FAITH,

promoters must exercise, in dealings with or for corporation, 23.

GUARANTY OF STOCK SUBSCRIPTION, does not necessarily make one a promoter, 15 .

HIGHEST INTERMEDIATE VALUE,

rule of, in suit by corporation against promoter for accounting, 83.

INCORPORATION,

consequences of defective or irregular compliance with statutory requirements for, 249-264.

de facto incorporation, 252-257.

de jure incorporation, 249.

construction of statute by courts of State where enacted followed

by courts of other States, 258.

certificate of incorporation, how far conclusive, 251.

INSOLVENCY OF CORPORATION, effect on right of defrauded subscriber for shares to rescind subscription or recover damages from corporation, 172, 190, 191.

INTEREST,

promoters chargeable with, when accountable to corporation for profits and commissions, 82 .

corporation chargeable with, on rescission of subscription, 174 .

INTEREST OF PROMOTERS, in certain contracts to be disclosed. (See Disclosure, Duties of Promoters.)

INVITATION OF PROMOTERS TO JOIN ENTERPRISE, effect of, 123-125.

JOINT LIABILITY OF PROMOTERS,

if combination to secure secret profits jointly liable, 76 .

effect of release of one, 241 .

LACHES,

bar to corporation's right to rescind contract with promoter, 101.

bar to suit by subscriber for shares to rescind subscription, 188 .

burden upon corporation to show, 190.

bar to shareholders' bill, 121 . 
LIABIIITY,

of corporation in damages to subscribers for shares for misrepresentation of promoters, $170,171$.

effect of corporate insolvency, 172, 191-193.

of corporation to promoters and agents,

for expenses and services incident to formation, 79 .

statutory liability, to those looking to corporation for pay, 218.

under English Companies Acts, authority to pay, merely, 219. no legal liability imposed, 220.

equitable liability on quantum meruit for whose benefit, 221.

American doctrines of liability, 222.

power of private corporations to pay formation expenses

wanting statutory or charter provisions, 222.

ordinarily none for services and expenses in procuring subscribers for shares, 223.

doctrine held in Vermont and New Hampshire criticised, 224.

of promoter to corporation,

for an accounting. (See Accountability.)

for misfeasance, ordinarily none, 90 .

otherwise when occasions pecuniary loss to corporation, 91, 92.

or injurious violation of fiduciary relation, $46,91,92$.

for fraud, 90, 92.

for damages, distinguished from accountability, 46 .

of promoters to subscribers for shares and shareholders,

for an accounting to individual shareholders, 123-125.

joinder of plaintiffs, 126 .

for misrepresentations generally. (See also Subscribers FOr SHares.)

when fiduciary relation exists, 127-129.

for misrepresentations of co-promoters, 157.

in action of deceit. (See Subscribers for Shares.)

when project fails of completion, 162 .

expenses not to be deducted unless authorized, 163 .

payment by subscriber to promoter or promoter's agent must be shown, 164-166.

lien, none in favor of subscribers as against creditors, 167.

remedy at law, unless frand or necessity of accounting shown, 169.

bill for accounting, 169 .

of promoter to purchasers of shares, none ordinarily for misrepresentations in prospectus, 140.

otherwise if connection is shown between promoter and purchaser of shares, $141,142$. 
LIABILITY - continued.

of promoter to third parties,

on contracts made in name or on behalf of corporation.

(See Contracts of Promoters.)

on contract before becoming promoter, 239.

upon non-compliance with provisions for incorporation, 249.

(See also Association and De Facto Corporation.)

individually, when incorporation really for unlawful purpose, 259.

for misrepresentation of co-promoters, 157 .

for acts of co-promoters, ordinarily none, 233 .

unless credit is placed on promoter's responsibility, 240 . authority, question of fact for jury, 234 .

not ordinarily from appearance of name in prospectus, 235.

nor from announcement that promoter and others are organizing a corporation, 235.

nor from signing and filing articles of incorporation, 235.

but may be from conduct in carrying on business, 235 . or from certain statements in prospectus coupled with promoter's name, 236.

or from having acted in the undertaking, question for jury, 237, 238.

or from acts showing knowledge and concurrence, 237, 238.

of promoter to co-promoter who has been held liable, 242 .

must contribute when all are jointly liable, 243,244 .

none to pay for service, wanting agreement, 245.

of promoter for misrepresentations generally, 23.

LIEN,

(See also Misrepresentation.)

none in favor of subscriber for shares as against creditors of abortive corporation, 167.

\section{LIMITATION,}

of action against promoter for profits, 84,85 .

statute runs from time facts become known to corporation, 86,87 .

\section{MAJORITY SHAREHOLDERS. (See Shareholders' Bill.)}

MEASURE OF ACCOUNTABILITY,

in actions by corporation against promoter where commission is stock, 83.

1 , transfer of shares to corporation, 83.

2 , payment to corporation of highest intermediate value, 83 .

3 , payment to corporation of proceeds from sale of stock by promoter, 83. 
MEASURE OF ACCOUNTABILITY - continued. of damages in actions by subscribers for shares against promoters, various rules, 158 .

Massachusetts rule, 159.

New Jersey rule, 160.

English rule; also of United States Supreme Court, 161.

MINORITY SHAREHOLDHRS. (See Shareholders' Bill.)

MISFEASANCE OF PROMOTERS,

not ordinarily ground for action by corporation for damages, 90 . otherwise if occasions pecuniary loss to corporation, 91, 92.

otherwise if injurious violation of duty to corporation, 91, 92 .

otherwise if fraud, 90, 92.

MISREPRESEN'TATIONS BY PROMOTERS, (See Subscribers FOR Shares.)

a question of substance, not of mere words, 151 .

liability of promoters therefor generally, 23 .

liability of promoter to shareholders when fiduciary relation exists, 127-129.

liability of promoter in damages to subscribers for shares when no fiduciary relation, 131 .

must be an assertion of fact, not opinion, 132-137.

what is au assertion of fact, 132 .

commendatory expressions privileged, 133.

caveat emptor, 130, n. 1.

statement of value ordinarily opinion and privileged, 133.

treated as fact when made as by expert and unprivileged, 134.

statements of price paid by third persons for shares, fact, unprivileged, 135.

statements of price paid by corporation for property, fact, unprivileged, 135.

expressions of hope and commendation in prospectus, privileged, 135.

ambiguous statements, when unprivileged, 136.

of law, purely, privileged (but see note 2), 138.

of mingled law and fact, not privileged, 138.

of law of foreign country, fact, unprivileged, 138.

must be of material fact, 139 .

when doubtful as to whether opinion or fact, jury to determine, 139.

must be fraudulent, 143 .

when negligent, not ordinarily actionable, 143.

unless a duty exists to be careful, 143.

must be made knowingly, without belief in its truth or reck.

lessly, 143.

motive of one fraudulently misrepresenting, immaterial, 143. false statements made as upon knowledge, deemed fraudu. lent, 144. 
INDEX.

References are to Sections.

MISREPRESENTATIONS BY PROMOTERS-continued.

forgetfulness of truth no excuse, 144.

when honestly made, though without reasonable cause for belief, not actionable, $14 \overline{\tilde{\nu}}$.

absence of reasonable cause for belief evidence of fraud, 145 .

when honest, discovery of truth imposes duty to correct, 146.

concealing material facts implies fraudulent, 147 . prospectus, undertaking in, not to tell all material facts, 149 . passive concealment or non-disclosure not ordinarily actionable, 150.

statement of portion of truth a false statement, when, 151. omissions in prospectus not actionable unless they make what stated false, 149.

when non-disclosure of particular facts made fraudulent misrepresentations, 148.

fraudulent misrepresentation ground for bill in equity, 150 . false inferences made plausible by partial statements of truth, 151.

as ground for action by purchasers of shares against promoter, ordinarily none from statements in prospectus, 140. different rule, when, $141,156$.

liability of corporation for, when made before incorporation, ordinarily none, 171 .

subscribers' right to rescind subscription for shares, 173 .

statements in prospectus not severable from application for shares, 173 .

(See also Subscribers for Shares.)

liability of co-promoters for, 157 .

will support indictment for conspiracy when, 156.

\section{MOTIVE,}

of one making fraudulent misrepresentations immaterial, 143.

\section{NON-DISCLOSURE BY PROMOTERS,}

corporation's liability therefor to subscribers. (See Subscribers FOR SHares.)

non-liability of corporation when prior to organization, 173 .

but prospectus not severable from application for shares, 173 .

non-disclosure of profits, gifts, or commissions as ground for action by corporation for accounting or damages, 42-48.

for rescission by corporation. (See Rescission.)

for action by subscriber against promoters for accounting or damages, 123-129.

under English Companies Acts, 154.

non-disclosure of material facts as ground for action of deceit by subscribers against promoters, 148-152. 
NON-DISCLOSURE BY PROMOTERS - continued.

suit in equity by subscribers against corporation, 150-152.

(See Accountability, Action, Commission, Concealment, Disclosure, Duties of Promoters, Profit, Prospectus, Subscribers for Shares.)

\section{OPINION,}

assertions of, by promoters ordinarily not actionable, 132, 137.

OPTION TO BUY PROPERTY, (See ACCOUNTABILITy.)

acquisition with intent to sell property to projected corporation evidence merely of promotership, 19.

when held by promoters, whether corporation entitled to benefit of, $54,56,57$.

circumstances under which corporation entitled to benefit of, 55 .

when held by person confederating with promoters, 58,59 .

\section{PARTNERSHIP,}

co-promoters not prima facie partners, 233.

promoters and shareholders of de facto corporation, no partnership liability, 253.

of association supposed to be corporation, but not even de facto such, as to partnership liability, 265.

\section{PRIVIleged STATEMENTS. (See Misrepresentations.)}

\section{PROFIT, (See Accountability.)}

what is distinguished from benefit, 60 .

circumstances under which promoters may retain profit, 32 .

promoter not to make secret profit on sale of property to corpora-

tion, 31,32 .

must be accounted for by promoter when property has market price, 61 .

but not if sale to corporation is properly approved by directors, 61 .

as to accountability for, when property sold has not market price, 62.

net profit only to be accounted for, 79 .

remedies when corporation makes payment in its stock, 83 .

interest, 82.

burden of proof, 104.

promoters, although majority shareholders, cannot retain secret profit, 117.

\section{PROJECTOR,}

not necessarily a promoter, 17 .

PROMISE,

to be a director may make one a promoter, 13 . 
PROMOTER,

explanation of term, 1 .

term not applicable to one acting as agent only, 2,3 .

one who is an agent may be a promoter also, 5,6 .

tests to ascertain who are promoters, $7,8,9$.

question of fact whether one is a promoter, 9-15.

mere intent or agreement to promote does not make one a promoter, 16.

absolute purchase of property with view to resale to projected corporation as evidence of promotership, 17, 18 .

conditional purchase of property with view to resale to corporation as eridence of promotership, 19.

promotership not limited to period anterior to organization of corporation, 20.

fiduciary relation of promoter to corporation, 21 .

existence of such relation established by authorities, 22.

in position analogous to that of trustee, 32 .

duties of promoter to the corporation, 24-37.

promoters may or may not be in fiduciary relation to subscribers

for shares, 123, 130.

promoters not prima facie partners, 233.

not prima facie each other's agents, 233.

accountability to corporation for profit obtained as vendors to corporation, 42-62.

for gifts and commissions, 63-78.

survival of cause of action against, 89 .

liability to corporation in damages for breach of duty or fraud, 90-92.

breach of duty or fraud by entitling corporation to rescind contract, 93-104.

wrongs by, to corporation, shareholders' bills to redress, 105-122.

liability to account to shareholders for profits, gifts, and commissions, 123-126.

in damages when in fiduciary position toward shareholders, 127-129.

when not in fiduciary position toward shareholders, 130-161.

liability to subscribers for shares when corporation proves abortive, 162-169.

misrepresentation by, as ground for action for damages by subscribers for shares, against corporation, 170-172.

as ground for rescission of subscription for shares or as

defence to suits thereon by corporation, 173-193.

contracts made by, in name and for benefit of projected corporation. (See ConTracts.)

rights and liabilities of, under such contracts. (See CoNTRACTS.) 
PROMOTER - continued.

rights and liabilities under contracts made by promoters claiming to be incorporated. (See Contracts.) contracts between promoters, 245-247. right of promoters to enforce payment from corporation for services or expenses incident to its formation, 218-224. (See Other Titles.)

\section{PROMOTION MONEY,}

explanation of term, 63 .

promoters must account for, 64-74.

in hands of vendor to corporation under secret agreement with promoter to be accounted for, 75 .

devices to evade rule as to, will be set aside, 49, 50, 73 .

\section{PROSPECTUS,}

issuing of, by promoter does not create fiduciary relation with sub. scriber for shares, 130.

no undertaking in, to set out all material facts, 149. must state agreements of promoters by Statute in England, 154. otherwise generally in United States, 153.

misrepresentations in, not ordinarily actionable by purchasers of shares, 140.

different rule when, 141, 156.

ordinarily promoter not liable from allowing his name to appear in, if he does not act in undertaking, 235.

but may be liable under some circumstances, 236 .

PURCHASE BY PROMOTER, (See Accountability.) benefit of, may belong to corporation, 28. when made by promoter acting as such, 42,43 . when promoter held option before he became promoter, 54-57. when made without sale to corporation in view, 44 . when made by promoter before he became such, 46-48. none unless promoter is bound by declarations or offers, 5153,55 .

what offer entitles corporation to benefit of, 55 .

made with intent to sell to corporation, evidence of promotership, merely, $17,18$.

\section{PURCHASERS OF SHARES,}

rights against promoters for misrepresentations in prospectus, generally none, 140.

different rule, when, 141, 142.

rights against promoters for misrepresentations made to create fictitious share values, 142 .

\section{RATIFICATION,}

by corporation is irrevocable if intelligently made, 100 .

election to ratify may be express or implied, 100 . 
RATIFICATION - continued.

distinguished from acceptance or adoption, 214.

used meaning acceptance or adoption, 212, 213.

RELATION,

between corporation and promoter is fiduciary, 21 .

consequences of, 23.

similar to that of trustee and cestui que trust, 21.

between promoter and shareholder not ordinarily fiduciary, 130 .

but may be fiduciary, 123-129.

RELEASE,

of one of several co-promoters who are jointly liable, releases all, 241.

REPRESENTATiON. (See Misrepresentátion.)

RESCISSION,

by corporation of contract with promoter,

elective remedy, 93.

for breach of duty by promoter to corporation, $94-97$.

right barred by laches, 101 .

must not be partial, 103 .

allowed unless promoter has disclosed material facts, 94-97.

consideration to be returned unless worthless, 102.

equivalent of consideration to be returned in what cases, 102 .

return of value of consideration in money ordinarily insufficient, 103.

burden of proof, 104.

by corporation of contracts with parties other than promoters for collusion, 99.

by minority shareholders when majority have practised fraud, 110-112.

when majority have not practised fraud, $113,114$.

in absence of any fraud, 115 .

of subscription for shares for misrepresentations or non-disclosure of promoters, 173-184.

several subscribers may join as plaintiffs, 174 .

what proof necessary, 187.

laches bar suit, 188.

waiver may be shown, 189 .

burden of proof to show laches or waiver on corporation, 190. without suit, 193.

effect of insolvency of corporation on suit for, 191, 192.

SALE OF PROPERTY BY PROMOTERS TO CORPORATION, if promoters have interest, must disclose it, 26.

promoters must see that corporation acts through competent and disinterested directors, 26 .

but not when full disclosure made to shareholders, 27 . 
SALE OF PROPERTY BY PROMOTERS TO CORPORATION - continued.

when necessary to disclose anterior price paid by them, 28-30. mere declaration of interest, without stating nature and amount, not enough when made to directors only, 33,34 .

but such declaration sufticient if made to the shareholders, $\mathbf{3 5}$. right of corporation to claim benefit of promoter's purchase. (See Benefit.)

to recover secret profit of promoters. (See Option, Profit.) to rescind purchase on ground of breach of duty or fraud of promoters. (See Rescission.)

right of shareholders to recover to their own use secret profits of promoters, 123-125.

\section{SHARES OF STOCK,} remedies when profit or commission recoverable from promoter is in form of shares of corporation's capital stock, 83 .

\section{SHAREHOLDERS,} right to an accounting from promoters, 123-125.

joinder of plaintiffs, 126 .

action for damages against promoters when in fiduciary relation, 127-129.

when relation not fiduciary. (See Subscribers for Sha res.) action against promoter to recover deposits on shares when corporation proves abortive. (See Abortive Corporation.) remedies against corporation when led to become shareholders by misrepresentations of promoters. (See Subscribers For Shares.

enforcing corporate rights and redressing corporate wrongs as against promoters. (See Shareholders' Bill.)

not liable for corporate debts, if corporation is a de facto one, 253. rights and liabilities when shareholders in association supposed to be a corporation, but which has no corporate existence even de facto, 263-265.

\section{SHAREHOLDERS' BILL,}

as general rule, suit can be brought only by corporation, 105 .

exceptions to rule, 106.

proof necessary to establish disability of corporation to sue, 107 .

transactions on account of which shareholders may or may not bring suit, 108.

exposition of rule on subject by Lords Justices James and Mellish, 109.

right of minority shareholders to sue to rescind transaction voidable for fraud, when majority are the wrong-doers, 110-112.

right of minority, where majority are not the wrong-doers, to ste to rescind contracts voidable for fraud, 113,114

right of minority to sue to rescind a voidable transaction where there is no fraud, 115. 
INDEX.

References are to Sections.

SHAREHOLDERS' BILL - continued.

right of minority to sue for recovery of secret profits obtained by promoters, 116.

majority not allowed to retain profits wrongfully obtained at expense of minority, 117 .

right of minority to sue for recovery of promoter's profits on sale to corporation at fraudulently excessive price, 118.

shareholder whose shares have been voted on in favor of a transaction cannot maintain suit based upon it, 119.

rule in federal courts, 120 .

shareholders' suit may be barred by laches, 121 .

form of shareholders' suit. Necessary parties, 122.

SUBSCRIBERS FOR SHARES, (See Shareholders.)

nature of contract with corporation, 211.

estoppel to deny legal incorporation, 262.

action against promoters when corporation proves abortive to recover payments made in adrance. (See Abortive CorporaTION.)

not ordinarily in fiduciary relation with promoters, 130 .

action against promoters for an accounting or damages, when in fiduciary relation, 123-129.

action for damages against promoters for misrepresentation when not in fiduciary relation,

when action will lie, 131.

misrepresentation must be assertion of fact, 132 .

mere commendatory expressions privileged, 133.

representations as to value in exceptional circumstances not privileged, 134.

representation as to price paid by third persons for shares, or as to cost of company's property, not privileged, 135.

commendatory expressions in prospectuses, 136.

expressions of opinion, although untrue, not actionable, 137. representations as to the law, 138.

representation must be of a material fact, 139.

promoters, as a rule, not liable to purchasers of shares for

misrepresentations in prospectuses addressed by them to prospective subscribers for shares, 140 .

but connection between promoters issuing prospectus and persons purchasing shares in reliance upon it may be shown, 141, 142.

representation must be fraudulent as well as false, facts to be proved to establish fraud, 143.

false representation made as of one's own knowledge deemed fraudulent, 144.

absence of reasonable grounds for belief in representation evidence that it is fraudulent, 145 .

effect of subsequent discovery by one who has made representation that it is untrue, 146 . 


\section{SUBSCRIBERS FOR SHARES - continued.}

fraud may be inferred from concealment as distinguished from non-disclosure of material facts, 147 .

circumstances under which non-disclosure of facts may make facts stated false, 148 .

omission of facts from prospectus not ground for action of deceit, unless it makes facts stated false, 149, 150 .

statement of portior of truth, with suggestions and inferences rendered credible only by suppression of other portions of truth, 151.

rules as to misrepresentation and non-disclosure not the same in actions ex-delicto as in suits for equitable relief, 152.

no legislation in this country requiring promoters' agreements to be disclosed in prospectuses, 153 .

English statute on subject, 154.

right of subscriber to rely on representations addressed to him, 155 .

liability of promoters on sale of shares issued to them at discount, or in payment for property at over-valuation, 156. liability of promoters for misrepresentations made by copromoters, 157.

conflicting views as to measure of damages, 158.

rule in Massachusetts and other jurisdictions, 159.

rule in New Jersey, 160.

rule laid down in England and by Supreme Court of United

States, 161.

action for damages against corporation for promoter's misrepresentations or non-disclosure,

action of deceit will lie against a corporation, 170 .

corporation ordinarily not liable in damages for frauds by promoters prior to its formation, 171.

effect of insolvency of corporation on right of suit by subscriber to recover damages, 172.

rescission of subscription, or defence to suits thereon by corporation, responsibility of corporation for misrepresentation or nondisclosure by promoters before corporation formed, 173.

subscribers' remedies against corporation for fraudulent misrepresentation by promoters, 174 .

remedy when misled by non-disclosure of facts by promoters, 175.

dicta of Vice-Chancellor Kindersley, 176.

dicta of Lord Chelmsford, 177

standard of duty as to disclosure required by dicta quoted; whether legal or moral duty, 178, 179 .

duty to disclose material facts not a legal duty when omission does not make facts stated false, 180 .

absence of direct decisions on this point, reasons for and agaiust requirement of disclosure, 181 . 
INDEX.

References are to Sections.

SUBSCRIBERS FOR SHARES - continued.

contracts to take shares governed by maxim caveat emptor, 182.

views of Brett, J., expressed in Gover's Case, 183.

relief obtainable in equity, and in some jurisdictions at law, against innocent misrepresentation, 184.

no relief at law where distinction in procedure between action at law and suit in equity adhered to, 185 .

principle on which equity rescinds or refuses to enforce contract induced by innocent misrepresentation, 186.

proof necessary to obtain rescission of contract of subscription on ground of innocent misrepresentation, 187.

laches as a bar to rescission of contract of subscription, 188. waiver of right to avoid subscription on ground of misrepresentation, 189.

burden of proof on question of laches or waiver, 190.

rule in England as to effect of corporate insolvency on right to rescind contract of subscription, 191.

tendency of decisions in this country, 192.

repudiation of contract of subscription without suit for rescission effective, although corporate insolvency proceedings subsequently begun, 193.

\section{SUBSCRIPTION FOR SHARES,}

nature of contract, 211.

liability of corporation for expenses of procuring, 223.

corporation not ordinarily liable, 223.

doctrine of the "burden with the benefit" criticised, 224 .

(See also Subscribers for Shares.)

SURVIVAL of action by corporation against promoter for an accounting, 89.

\section{SWELliNg PRICE. (See Promotion Money.)}

\section{TRUSTEE,}

rule as to secret profits by, 31 .

analogy of promoter to trustee, 32 .

\section{ULTRA VIRES ACTS,}

transactions ultra vires the corporation not validated as to subsequent shareholders by assent of all the shareholders for the time being, 41 .

ground for shareholders' bills, 108, 109.

cannot be accepted or adopted by corporation, 217 .

expenses ultra vires the corporation, promoters not allowed for, 80 . 


\section{VENDOR TO CORPORATION,}

may be a promoter and liable as such, 8 .

accountable to corporation for secret promotion money, if in his hands, 75 .

agent of, may be a promoter, 4,5 .

\section{WAIVER,}

burden on corporation to show in suit by subscriber to rescind subscription, 190. 

LAW LIBRARY UNIVERSITY OF CALIFORNLA LOS ANGELES

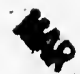

${ }_{0}^{0}$ 


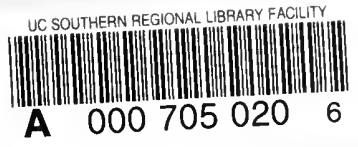




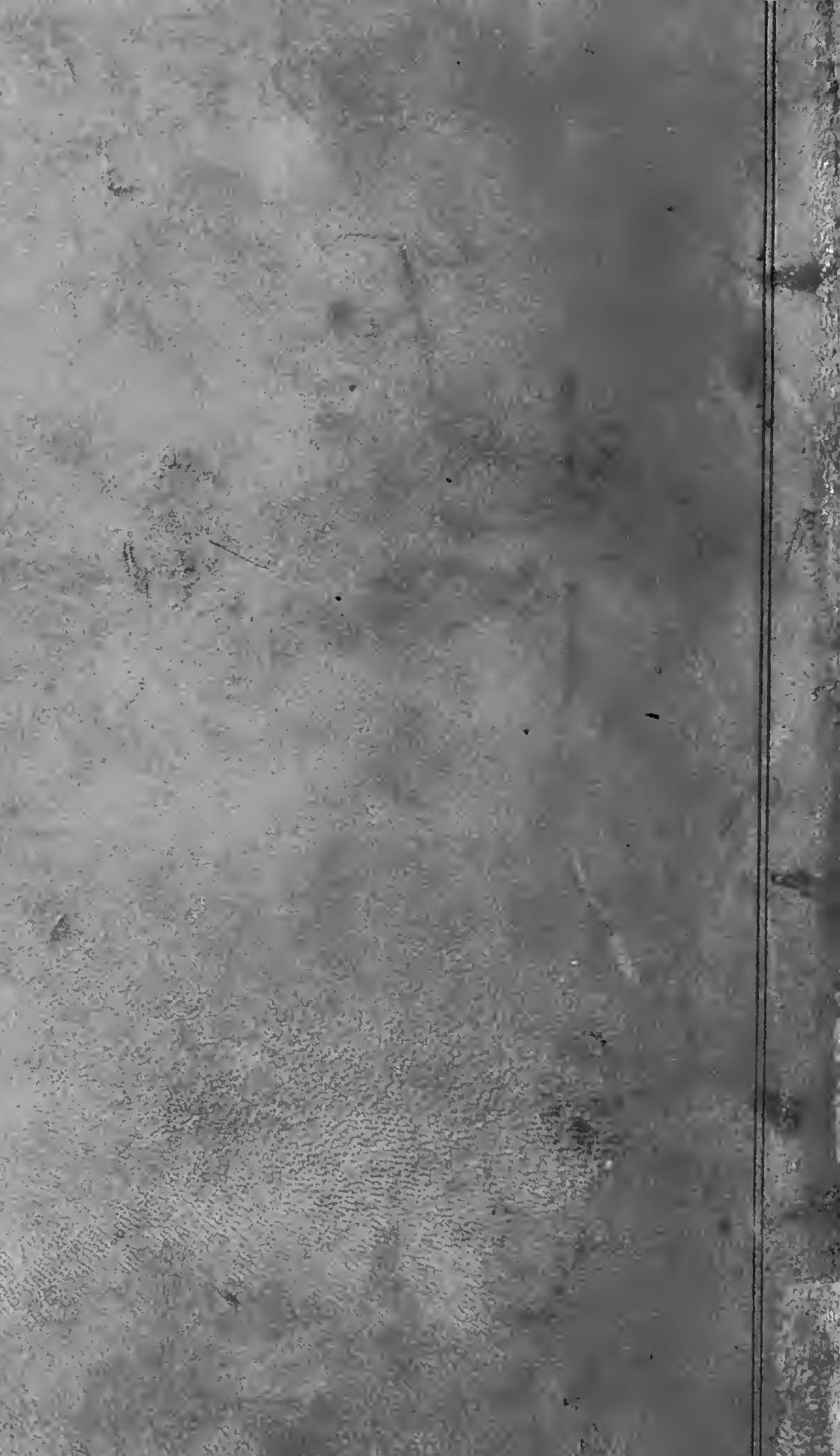

